\title{
The Future is Bright - or is it? Comparing Opportunities across the Generations in the UK
}

Lewis R. Anderson

Department of Sociology \& Nuffield College

University of Oxford

March 2022 


\section{Acknowledgements}

This report contains some original analysis, but it mainly draws on high-quality research done by many others. I would especially like to acknowledge the Institute for Fiscal Studies and the Resolution Foundation, whose research I cite a great deal in what follows.

In every case where I have contacted an author to ask permission to reproduce a figure, they have kindly given this permission and even in some cases gone so far as to add intervening years of data to their analyses to bring them up to date (special thanks to Lindsay Judge and Vikki Boliver). I believe this responsiveness reflects a well-functioning research community but also one that is genuinely concerned about the issues discussed in this report, and keen that pertinent evidence should be seen by as many as possible.

Thanks to Jonathan Cribb, Robert Joyce, Richard Blundell, Pascale Bourquin (Institute for Fiscal Studies), Lindsay Judge (Resolution Foundation), Vikki Boliver (Durham University), Annalisa Cristini (University of Bergamo), Andrea Geraci (European Commission), Daniel Oesch (University of Lausanne), Greg Brooks (University of Sheffield), Francis Green (University College London), John Goldthorpe, John Muellbauer, Erzsébet Bukodi, Christiaan Monden, Lindsay Richards, Stephen Fisher, Colin Mills (University of Oxford), and Roger Ford.

And thanks of course to The Future is Bright Charitable Trust (thefutureisbright.org), which has commissioned and funded this research.

Lewis Anderson

lewis.anderson@sociology.ox.ac.uk

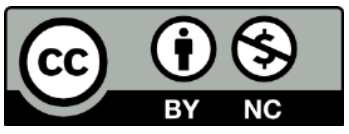

This work is licensed under a Creative Commons Attribution-NonCommercial 4.0 International License.

The UK House Price Index is HM Land Registry data @ Crown copyright and database right 2020.

This report reproduces data from the Office for National Statistics (ONS) licensed under the Open Government Licence v.3.0. This work was produced using statistical data from ONS. The use of the ONS statistical data in this work does not imply the endorsement of the ONS in relation to the interpretation or analysis of the statistical data. This work uses research datasets which may not exactly reproduce ONS aggregates.

Chapter 5 (under the heading 'Direct comparisons of wealth') includes results derived from Secure Access data from the ONS Wealth and Assets Survey. With respect to these results: ONS agrees that the figures and descriptions of results in the attached document may be published. This does not imply ONS' acceptance of the validity of the methods used to obtain these figures, or of any analysis of the results. 


\section{Summary}

I review social, economic, and policy trends across education, employment, housing, and wealth in the UK over the past half-century, and compare how different generations have fared in each of these areas. Younger generations cannot be said to have had it wholly 'better' or 'worse', but a recurrent finding is a decline in the opportunities available in all these areas to young people who do not enter higher education and lack other advantages such as access to parental wealth. Among the likely ongoing consequences of this decline are a less open society, lower productivity, and lower fertility.

Chapter 6, starting on page 81 , gives a more substantial summary of the report.

This work was commissioned by The Future is Bright Charitable Trust, whose goal is to mobilise older generations to help pass on opportunities to young people. In this spirit, chapter 6 ends by offering suggestions for individual action with respect to education and employment, housing, and investment. 


\section{Contents}

Acknowledgements 2

Summary 3

Contents 4

Foreword - University of Oxford 6

Foreword - The Future is Bright Charitable Trust $\quad 7$

1. Introduction 10

$\begin{array}{ll}\text { The fortunate generations } & 11\end{array}$

$\begin{array}{ll}\text { What this report does } & 12\end{array}$

What this report shows: a preview 13

$\begin{array}{ll}\text { Why does this matter? } & 14\end{array}$

The opportunity: seniority, time, expertise, and wealth 16

2. Education and skills $\quad 18$

Educational expansion and academicisation $\quad 18$

The vocational route $\quad 23$

Education spending and student finance $\quad 24$

$\begin{array}{ll}\text { Teacher pay and conditions } & 27\end{array}$

$\begin{array}{ll}\text { Restructuring } & 27\end{array}$

$\begin{array}{ll}\text { Private tuition } & 28\end{array}$

Social class inequality in education $\quad 29$

Have standards improved? $\quad 32$

Basic skills among working age adults 35

3. Employment and earnings 36

Deindustrialisation and the rise of services

Women's participation in the labour market 38

Occupational upgrading and polarisation $\quad 39$

Productivity and wage stagnation $\quad 42$

Regional and income inequality 44

Work intensification $\quad 45$

The youth labour market $\quad 46$

$\begin{array}{ll}\text { An oversupply of graduates? } & 47\end{array}$

Generational comparisons: employment status 49

Generational comparisons: earnings and career progression $\quad 51$

Generational comparisons: job security and hours $\quad 57$

4. Housing $\quad 60$

$\begin{array}{ll}\text { The housing problem } & 60\end{array}$ 
The price of houses...

.... and the price of housing

The housing trilemma for young people

The impact on younger generations

From housing to wealth: the impact on older generations

Investment in property

5. Wealth

The loss of defined-benefit pensions

Direct comparisons of wealth

6. Summary and Conclusion

Where progress has been made

Problems facing younger generations

Suggestions for action 


\section{Foreword - University of Oxford}

How have different generations fared in the UK over the last half-century? The underlying question of this report goes to the heart of one of the social sciences' main questions, which in its simplest form asks: who gets what? Describing how and understanding why opportunities and outcomes vary over time and across societies has a long tradition in sociology and is a key research area for the Department of Sociology at Oxford.

We were pleased, therefore, when The Future is Bright Charitable Trust commissioned a study comparing how each of the post-war generations have fared in the UK, with special attention to education, employment, housing, and wealth. The Covid pandemic has brought to the fore, perhaps more than ever, not only how closely linked people of different generations are but also how different their life chances - sometimes literally - can be.

This report builds on and syntheses a rich but complex and fragmented body of research and data to shed light on what might read as a deceptively simple question. Using the best available data and research results for a carefully selected range of indicators, it paints a comprehensive picture of the different opportunities and challenges that members of successive birth cohorts have faced.

When studying differences between generations, it is tempting to focus on a single aspect of life, where perhaps we can tell a straightforward story of success or decline. But our social reality is much more complex than that. Not all trends move in the same way. We believe there is great value therefore - as well as a huge analytic challenge - in bringing together these many stands and storylines. This report provides a transparent and comprehensive account that does justice to the complex developments we have seen in the UK over the last fifty years.

We hope this report will provide valuable input for individuals, public and corporate policymakers alike, as well as anyone interested in thinking about the current and future life chances of our generations and how we got to where we are now.

Federico Varese

Professor of Criminology and Head of Department

Department of Sociology 


\section{Foreword - The Future is Bright Charitable Trust}

The Future is Bright Charitable Trust is pleased to have sponsored this research by Oxford University, looking at intergenerational differences in opportunity in Britain over the last fifty years. It is the first research we have commissioned, and we plan further research over the coming years to understand Britain today and support our goals for change to improve the lives of young people.

The Future is Bright Charitable Trust was set up in early 2020 before the ongoing Covid pandemic. The charity was set up to sponsor research looking at how the older generations of today - the Baby Boomers and Generation X, which the Founding Trustees of the charity are part of - can help use their time, know-how and wealth to carry out research, lobby for change and, most importantly, offer practical solutions to the challenges facing younger people today. We are particularly interested in the areas of education, employment and housing. We are also interested in how values in society have changed over time and across the generations.

The past couple of years will mainly be remembered for the Covid pandemic. But they have also seen the average Baby Boomer reach the state pension age of 66: an opportune time for reflection. At the same time, the average Millennial is in their early 30s when, in days gone by, individuals would see progress in their career, settle into a family home and raise a family. These are crucial milestones in everyone's life. Without a good education, stable and fulfilling career and a good, affordable home, individuals cannot flourish. And if individuals do not flourish, society as a whole is worse off.

If young people do not get the education needed to equip them for the twenty-first century, if they do not feel they have a stable and rewarding job, or if they cannot afford good quality housing, they lose hope. We believe hope is one of the key drivers of a strong society. Without hope, people feel despondent, they don't fulfil their potential and the nation's economic and social capital declines. This has a negative effect on cohesion in society and changes the country for the worse. Hope is essential; that is why we called the charity The Future is Bright Charitable Trust.

Fundamentally we believe that each generation has a responsibility to be a custodian for future generations. But we also believe that the Baby Boomers and Generation X were very fortunate to have been born when they were. We were born at the right time and history has been kind to us. More importantly, our success has not all been down to just ourselves.

The generations that went before us, particularly since the turn of the twentieth century, opened up huge opportunities for us and sometimes many of us forget that. Our grandparents fought the wars to free Europe from tyrannical rule, our parents' generation set up the welfare state and free education for all and, since the 1960s, social attitudes, financial deregulation and changes in the housing market have delivered opportunities to our generations that none of our parents could ever have imagined. They have also brought much higher levels of wealth, now concentrated in the older generations, particularly since 2000 when interest rates have been at historic lows for a prolonged period of time and the young have been ravaged by two major recessions in just over a decade. Household wealth in Britain has soared from three to seven times national income according to the Resolution Foundation - and Baby Boomers alone hold more than half of it. Through the lottery of birth, as generations, we have been lucky. Any of us could have been born at any time and in any place. None of us had any control over that.

Many of the Baby Boomer and Generation X cohorts, like us, had our formative years during the Thatcher era. That instilled a belief that personal success was only down to one's individual hard work and talent. That the fruits of our labour were solely of our own making. Thatcher famously said "And, you know, there's no such thing as society. There are individual men and women and there are families." 
But all of us are shaped by society, shaped by what others before us had done to give us a leg-up. If you ever study your own family history, you will most often find a story of personal sacrifice of others striving to build a better tomorrow. Not just family members though. Total strangers over time have provided an infrastructure through which our generations could flourish. Every one of us has been touched by strangers throughout our lives who have been instrumental in helping us realise our potential - be it a teacher who saw talent where others didn't, an interviewer offering us that all-important job, an older colleague mentoring us along the way to successful careers. We didn't do it alone. As E.H. Carr said in his brilliant 1961 essay What is History?, "As soon as we are born, the world gets to work on us and transforms us from merely biological into social units." Society does matter.

The word transform is the key word. Many of the Baby Boomers and Generation X have had their lives transformed and had opportunities they would never have imagined when they started out in the 1960s, 70s and 80s. Many were the first in their family to go to university, to have successful and interesting careers, to see the world and have a level of financial security that none of their ancestors could have dreamt of. The revolution in financial services and the explosion in the associated legal and other services since the deregulation of the early 1980s has taken many children from humble backgrounds, through university or not, fast-tracked their careers and catapulted them into the plutocrats of today. Financial markets have also created a new class of entrepreneurs, not seen in our parents' time. These are the holders of wealth in Britain today and people in positions of power who can make a difference.

It is only fair that future generations believe they can live the same dream and fulfil their potential in all aspects of their life. Society changes over time, as it should, and each generation faces its own challenges and has the opportunity to create a new future. But the ladders of success need to be kept in place. And individuals of all back grounds still need the core building blocks of stability to enable them to flourish- a good education to equip them for the workforce, a stable and fulfilling job and a safe, good, affordable place to live and raise a family.

This report looks at each of these areas and compares the opportunities that different generations have had over the last fifty years. It also questions some policy decisions made by successive governments of all colours. Our key focus is to compare the opportunities that different generations have had at specific ages: when they finish school, leave university, start in the workforce and buy their first home. By thinking through this lens, it helps each of us compare the path that our own children, grandchildren and nieces and nephews are following today with the path we followed when we were the same age. We hope that comparison makes the research more real.

Each of these topics warrants a major piece of work in its own right. This report only looks at some of the key trends across the generations and highlights issues that deserve more research and wider attention. It does not pretend to look at all the issues, nor to have all the answers.

\section{Why bother?}

You may ask yourself the question "Why bother?" You have worked hard over the years, deserve what you have earned and it's up to others to take their own chances and make a success of their own life. You have focused your time and energy on helping your own children get from A to B. Now it is time to enjoy your retirement.

To some extent, we agree. But we also believe that we are all interconnected and that those who have so much today should never forget their humble beginnings. I am sure you can think of at least a few moments in your life when you were extremely lucky. When we look back on our careers, it is more often than not complete strangers who helped us on the way. Now it is our turn to fulfil that role. 
Today, the Baby Boomers and Generation $\mathrm{X}$ have a unique opportunity to use their later years in serving younger generations. The new retirees and 50-somethings like us are, or soon will be, empty nesters who can make a huge difference in effecting change in modern Britain.

\section{Where do we start?}

Have you ever thought about going back to your old school and transporting yourself back to your 16 year old self today? What would be your chances of getting to the same university, getting that first career break and promotion trajectory that you had throughout your career? Would you make Partner or Director at the same age? Would you still be able to get that life changing promotion at the same age today? Would you still be able to buy that same first house at the same age and start a family when you did? Would you be able to amass the same level of wealth starting out again today from the same position?

These are the questions we have been asking. We wanted to understand how Britain has changed over the last fifty years and if there is still the same hope today as in yesteryear when we were starting out. Hopefully, the data we share in this report will help you reflect on these questions and form your own conclusions.

It is estimated that people born in or before 1970 collectively hold $84 \%$ of Britain's private wealth, totalling over $£ 11.5$ trillion. ${ }^{1}$ A lot of this wealth is what we refer to as unproductive wealth, not benefiting anyone apart from its holder, like most housing wealth. Imagine if a small fraction of this wealth could be put to work in productive causes during your lifetime, to support young people in building the companies of tomorrow, funding research to avert the climate crisis made far worse during our watch, or helping to improve the education system for our grandchildren. We believe that the older generations now have the time, experience and wealth to make a real difference in effecting change where it is needed. We also believe that individuals who have a proven track record in their own careers can make a bigger positive impact than Government. You just need to look at the policy decisions in education, employment and housing over the last fifty years to see that for yourself: often a constantly muddled experiment reflecting short-term thinking and doing very little to improve real-life opportunities for the young, particularly those who don't start from a position of privilege.

It shouldn't only be the younger generations who are the agents of change. Imagine if the collective know-how, experience and wealth of older generations could be used to mobilise a shift in the way we look at generational opportunities. A shift in the education system, the workplace and the housing market. We are calling for a collective effort by those who have so much to make Britain a true country of opportunity.

We would like to thank the team at Oxford University and especially Lewis Anderson who has completed the report. We hope you enjoy reading it.

Most importantly, we hope you feel passionately about transferring opportunities across the generations and help support our future projects.

\section{Mark Kinvig, Founder}

\footnotetext{
${ }^{1}$ Based on figures reported in Table 1.2 below using ONS data from 2014-16. Imputing the 2014-16 generational distribution of household wealth to ONS figures from 2018-20 and taking into account increases during the pandemic, this figure is now likely over $£ 13$ trillion (Anderson).
} 


\section{Introduction}

How are the different generations faring in the United Kingdom today? ${ }^{2}$ Have today's children and young adults had the same opportunities as their parents? If not, why not? And what - if anything - can be done?

These are not simple questions. There can be no all-satisfying overall answer to the question of whether younger generations have had it 'better' or 'worse' than their recent predecessors. For one thing, too much of human experience is impossible to meaningfully measure, let alone compare across this time of profound social and technological change. How would we weigh up the impact of the internet? Today's children have effortless access to barely conceivable amounts of information - but are also constantly exposed to the many downsides of online life. We live in a time of greater choice, possibility, and material wealth, but also an obesity epidemic, gradual environmental catastrophe, and probably more loneliness than ever before. In many ways, each new generation faces its own unique set of challenges and opportunities.

In this report I focus on what can be compared over time and across generations. There are caveats to many of the comparisons I will make, but the measures I show nonetheless represent some fundamental indicators of human welfare. I give an overview of trends in four central aspects of people's lives: education and skills, employment and earnings, housing, and wealth. These are the economic foundations of the opportunity to live a fulfilled, purposeful life and be a productive member of society. Having the skills to contribute and being seen as playing a useful part are central to our sense of self. Secure, affordable housing and a steady job are valuable in themselves, but are also widely seen as prerequisites for starting a family and raising the next generation.

Progress is always hard-won and uneven, and cannot be taken for granted. But it should certainly give us pause if we see stagnation or even decline with each new generation of young people. Few would object to the idea that each generation has a responsibility to leave the world in at least as good a place as they find it, and to ensure that the opportunities they enjoyed are available to subsequent generations.

Concerns of stalling progress across the generations are sometimes founded on the impression given by the here and now, rather than on comparisons of different generations at a given age. Valid comparisons between the generations therefore require comparable data extending back several decades - to when members of today's older generations were themselves young adults. The past into which such data offer us a window is easily forgotten, especially by those who were not alive at the time. Many Baby Boomers reading about a 'housing crisis' and the plight of 'Generation Rent' Millennials will have memories of desperate scrimping and saving to get on the housing ladder, and of a wave of mortgage arrears and repossessions in the wake of the early 1990s recession. That economic hardship is no less real for having happened thirty years ago.

Accordingly, this report draws on long-running large-scale government surveys and administrative datasets, as well as widely-trusted academic survey data. However this does entail a trade-off: decades ago, we weren't measuring everything we now wish we had been measuring at the time. Sometimes the best answer to the kinds of questions examined in this report is that we just don't know.

It is worth pausing for a moment to be clear whom we are talking about when we talk about 'Baby Boomers', 'Generation X', or any other contemporary generation. Table 1.1 provides a quick overview

\footnotetext{
${ }^{2}$ This report focuses on the UK as a whole where possible, but data are sometimes only available for Britain, England, or England and Wales. Across much of the world, younger generations plainly are faring better, at least on measures such as life expectancy, child mortality, and material living standards (see e.g. OurWorldInData.org).
} 
of the generations in terms of their birth years, and a broad-brush impression of their respective life stages and some of the major events or trends that have marked their life and times.

Table 1.1 Generations at a glance.

\begin{tabular}{|c|c|c|c|c|c|}
\hline Generation: & Silent & Baby Boomers & $\mathbf{X}$ & Millennials & $\mathbf{Z}$ \\
\hline Years born & $1928-1945$ & $1946-1964$ & $1965-1980$ & $1981-1996$ & $1997-2012$ \\
\hline $\begin{array}{l}\text { Age range (end } \\
\text { of } 2021 \text { ) }\end{array}$ & $76-93$ & $57-75$ & $41-56$ & $25-40$ & $9-24$ \\
\hline $\begin{array}{l}\text { Size (millions, } \\
\text { UK, mid-2020) }\end{array}$ & $5.8^{*}$ & 14.1 & 14.0 & 14.3 & 12.7 \\
\hline $\begin{array}{l}\text { Percentage of } \\
\text { population (UK, } \\
\text { mid-2020) }\end{array}$ & $8.6^{*}$ & 21.1 & 20.8 & 21.3 & 18.9 \\
\hline Life stage & $\begin{array}{l}\text { Retired, } \\
\text { grandparents or } \\
\text { great- } \\
\text { grandparents }\end{array}$ & $\begin{array}{l}\text { Soon-to-be or } \\
\text { recently retired, } \\
\text { 'empty-nesters' }\end{array}$ & $\begin{array}{l}\text { Nearing peak of } \\
\text { career, parents of } \\
\text { teenagers \& } \\
\text { young adults }\end{array}$ & $\begin{array}{l}\text { Starting families } \\
\& \text { careers, } \\
\text { wanting their } \\
\text { own home }\end{array}$ & $\begin{array}{l}\text { In education or } \\
\text { recently entered } \\
\text { labour market }\end{array}$ \\
\hline $\begin{array}{l}\text { Defining } \\
\text { events/trends }\end{array}$ & $\begin{array}{l}\text { WWII, postwar } \\
\text { austerity }\end{array}$ & $\begin{array}{l}\text { Cold War, Space } \\
\text { Race, social } \\
\text { liberalisation }\end{array}$ & $\begin{array}{l}\text { Collapse of } \\
\text { Soviet Union, } \\
\text { free markets and } \\
\text { globalisation, } \\
\text { birth of internet }\end{array}$ & $\begin{array}{l}\text { September } 11^{\text {th }} \\
\text { attacks, Global } \\
\text { Financial Crisis, } \\
\text { austerity, social } \\
\text { media }\end{array}$ & $\begin{array}{l}\text { Covid pandemic, } \\
\text { climate change, } \\
\text { streaming media }\end{array}$ \\
\hline
\end{tabular}

*includes approximately 250,000 born 1927 and earlier.

These labels - 'Gen X' and so forth - have an intuitive appeal and provide us with an everyday language for talking about different birth cohorts - people born in the same year or group of years. But they are also very broad - spanning up to 19 birth years - and arguably quite arbitrary. The older and younger members of Generation X in particular are often rather different on the measures I examine. And it is not obvious that 'Boomers' are more similar to one another than are those born 1956-1974, for example. For this reason, in the course of this report I will often break the generations down into ten- or even five-year birth cohorts to allow us to get a more detailed picture. Sometimes, on the other hand, I will use these broad 'generation' labels for ease of presentation when there is little further nuance to be uncovered by using narrower cohort groups. When I use the terms 'older' and 'younger' generations I am mostly referring, approximately, to the Baby Boomer and Millennial generations respectively, but this varies slightly depending on context.

\section{The fortunate generations}

A focus on generations (or cohorts) here should not obscure the fact of substantial inequality within as well as between generations. To say the least, there are many Baby Boomers who have not fared well economically, just as there are many wealthy Millennials. But the Baby Boomers who have done well out of life have done extraordinarily well out of it. As in all affairs, this can be put down to a combination of their own effort and ingenuity, and favourable circumstances over which, as individuals, they had little or no control (Frank, 2016; Williams \& Nagel, 1976).

A large number of Baby Boomers might reflect that the economic backdrop to their life and times has, on balance, been a kind one. A small minority went to university, but those who didn't could often find other paths of advancement to lucrative careers; good jobs didn't tend to require a degree. Once they were established in the workplace, privatisations, tax cuts, and deregulation of the labour market and financial sector saw top incomes rise. Globalisation and technological change offered unique and hugely consequential windows of opportunity (try setting up an online bookshop today). Housing policy was directed towards increasing homeownership. This included selling large numbers of council homes at a substantial discount. Shares in former state enterprises were sold at low prices and went on to strikingly 
outperform the stock market as a whole (Lodge, 2010). From the early 1990s onwards interest rates fell; following the financial crisis, rates fell almost to zero which, in concert with quantitative easing, increased the value of assets to unprecedented levels, handing property owners a massive windfall. When the pandemic hit, many were able to work from spacious homes with gardens. Perturbed by the possibility that they might be unlucky enough to face care costs in old age running into the hundreds of thousands of pounds, this year those worries were assuaged by the introduction of a cap on these costs which ring-fenced their accumulated wealth and a Health and Social Care Levy falling solely on the working age population.

The scope of this pattern proves to be quite wide. David Willetts (2019) sought to convey basically the same observation, and incidentally he was able to do so drawing on an almost entirely different set of examples:

Inflation was high when they had big debts and low when they became richer; housebuilding was high when they needed houses but much lower when they had their own homes; credit was easy when they needed to get started on the housing ladder but much stricter afterwards; pension promises were weak when they were joining pension schemes but then were turned into gold-plated guarantees for them, after which companies stopped making such promises for future generations; benefits for old people were low when the Boomers were young but are worth much more relative to benefits for young people now the Boomers are old; consumption was high among young people when they were young and now is lower among young people and higher for older people; the Boomers' parents stuck together for them but then the Boomers were much more likely to split up once they themselves were parents.

Laurie Macfarlane (2017) is another to draw attention to the implications of economic trends that have been going on in the background of most Baby Boomers' lives, but benefitted them enormously:

When the value of a house goes up, the total productive capacity of the economy is unchanged because nothing new has been produced: it merely constitutes an increase in the value of the land underneath. ... The truth is that much of the wealth accumulated in recent decades has been gained at the expense of those who will see more of their incomes eaten up by higher rents and larger mortgage payments. This wealth hasn't been 'created' - it has been stolen from future generations.

'Stolen' perhaps goes too far by implying a purposive act. And increasing house prices might indeed reflect a growing economy and rising incomes - but as we will see, house price rises have far outstripped rising incomes. The broader point made by Macfarlane is difficult to dispute.

\section{What this report does}

The next four chapters focus on education and skills, employment and earnings, housing, and wealth. Within each chapter, I first describe important large-scale trends to show how the contexts in which we learn, work, live, and build for the future have changed across the generations. Later in each chapter, so far as is possible, I explicitly compare how different generations have fared on particular measures when considered at the same age. ${ }^{3}$ Figure 1.1 gives a typical example. Each line represents those born

\footnotetext{
${ }^{3}$ To be explicit: I therefore infer the opportunities available to birth cohorts from those cohorts' realised outcomes. This could misrepresent opportunities if cohorts differ in the extent to which they value certain goods, but this seems highly unlikely for the most part, given the areas this report considers.
} 
in a certain set of years. ${ }^{4}$ Rather than focusing on any one particular line, the point is to notice how the pattern changes as one looks from the dark purple, to the pale purple, to the pale green, and finally to the dark green line - that is, from the oldest cohorts to the youngest. In cases where long-running datasets with consistent measurement of valid indicators are available, we can thus track each cohort on the measure in question as it ages, and compare different cohorts at the same age.

The report concludes with a summary focusing on problems facing younger generations, and - at the request of The Future is Bright - suggestions for action that individuals can take to address some of these problems.

Figure 1.1 Living in private-rented housing, by age and birth cohort (\%).

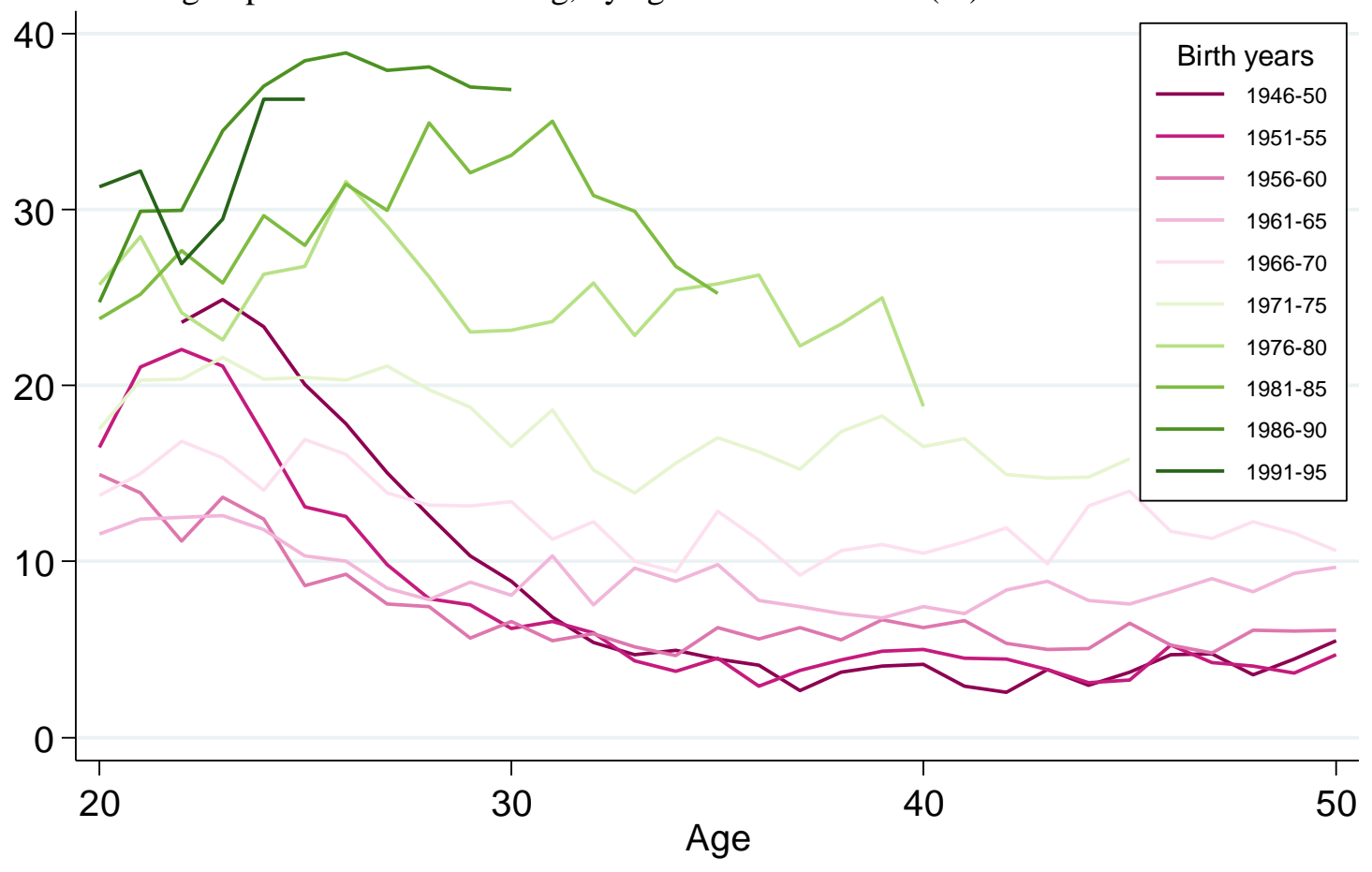

Source: Family Expenditure Survey 1968-2001, Living Costs and Food Survey 2002-2020. Institute for Fiscal Studies Derived Variables Dataset, updated with most recent data.

\section{What this report shows: a preview}

This report covers a lot of ground. In the broadest of terms, some of the main findings - elaborated further in the conclusion - are:

- Both men and especially women are spending far longer in education and it is better resourced than previously - except for adult and vocational education. However there are good reasons to be concerned about the unconstrained expansion of higher education in its current form. Among these are its substantial cost - resources which might be better allocated elsewhere and are arguably being wasted to a substantial extent - and the self-reinforcing nature of educational expansion: the more young people take this route, the more their peers are judged against this standard and themselves incentivised to go. For the majority who do not enter higher education, the path from school to work has become confused and confusing. We lack good evidence on

\footnotetext{
${ }^{4}$ I have only plotted points for ages which all members of a birth cohort have passed through, to ensure a comparison of like with like.
} 
whether standards have improved and people are really getting a better education. Crossnationally, the UK lags behind in young workers' literacy and numeracy.

- Every generation since the Baby Boomers has seen high youth unemployment. Generation-ongeneration increases in earnings have stalled and even gone into reverse. While the occupational structure as a whole has upgraded substantially over the past half-century, far more men and women in their 20s than previously are in low skill employment, and fewer in medium skill employment. There is some evidence that career progression has slowed. An ever larger pool of young graduates are competing for high skill work, and very large numbers are not in graduate employment.

- A home with security of tenure is unattainable for far more young people today than previously, and particularly for those without access to parental wealth. Younger generations are far less likely to be homeowners or in social housing at a given age, and far more likely to live in the private rented sector or with their parents. More children than ever before are growing up in private rented accommodation. Private rented accommodation is also the most likely to be classified 'non-decent'. Younger generations - especially those renting privately - spend a far higher proportion of their income on housing. At the same time, the majority of owner-occupied properties in England are under-occupied. 20\% of private tenants receive housing benefit: the taxpayer paying the landlord.

- A variety of factors including sustained low interest rates and constraints on supply have led to large (and untaxed) passive gains in housing wealth for older cohorts. These groups have also invested heavily in property additional to their main residence, with approximately one-in-six Baby Boomers holding additional property wealth, mostly in the form of buy-to-lets and second homes. Baby Boomers and Generation X together collectively hold over half a trillion pounds in additional property wealth.

- Although the data do not allow comparisons across whole generations, it is likely that younger generations have fallen or at least will fall quite dramatically behind in terms of wealth over their working age lives due to low homeownership, the decline of defined-benefit pensions, and the low likelihood of similar passive gains to those enjoyed by older generations.

\section{Why does this matter?}

It goes without saying that different generations depend on one another. There is a natural intergenerational reciprocity that we all engage in across our lives. Most people subscribe to the belief that each generation owes it to the next to at least pass on the same level of opportunity, if not improve upon it.

There are other, subtler reasons to be concerned about the problems younger people are facing. One relates to how open we want society to be in future - whether we want to be a nation split between inheritors of wealth on the one hand and intergenerational tenants on the other. Macfarlane's (2017) analysis quoted above continues:

The past few decades have spawned a one-off transfer of wealth that is unlikely to be repeated. While the main beneficiaries of this have been the older generations, eventually this will be passed on to the next generation via inheritance or transfer. Already the 'Bank of Mum and Dad' has become the ninth biggest mortgage lender. 
The ultimate result is not just a growing intergenerational divide, but an entrenched class divide between those who own property (or have a claim to it), and those who do not.

Second, there are implications for how competitive and productive we want society to be in future. As I discuss below, the UK is far less productive than many peer countries, such as Germany. Productivity and accordingly wages have largely stagnated since the financial crisis. Two of the key reasons many economists cite for this are workers' relatively poor (and often mismatched) skills, and a lack of investment in productive activities - be that training, capital expenditure, research and development, or elsewhere. This should direct our attention to the education system and how well it is serving young people's development. And to the housing market - so dire for young people - which as Muellbauer argues in detail is closely linked to productivity growth. Among these links are that high housing costs in the UK 'make it an expensive place to do business' (2018: R28) and make it difficult for workers to follow employment opportunities, ${ }^{5}$ and that with so much lending going towards financing house purchases at high prices (rather than, for instance, financing housebuilding), 'UK finance has been diverted from more productive uses' (2018: R27).

I will dwell briefly on just one more reason why this all matters. You could term it how old we want society to be in future. Consider these three facts. First, life expectancy grew dramatically over the course of the twentieth century in the UK - we are living longer than ever. Second, the Baby Boomer generation is a particularly large one, far larger than the Silent Generation that preceded it (hence the name). Third, health and social care in old age - particularly if it is to be of good quality - is expensive and labour intensive, meaning technology is unlikely to bring down costs to the same degree as in other sectors.

Taken in combination, this means that the ratio of working age adults to dependents is going to carry great importance in coming years, both for the funding of health and social care and for the stability of the economy as a whole. This in turn is one reason why it matters whether younger adults today feel ready and able to start families and have children. However it seems they increasingly do not: England's total fertility rate 'reached its historically lowest level in 2020' after a decade of decline (Ermisch, 2021: 903).

Figure 1.2 presents this trend from a cohort perspective. Successive generations of women are having fewer children on average. We cannot measure a cohort's total fertility until the age of about 45 , but measures from earlier ages give a signal of where things are likely to be heading. Fertility by age 30 has held steady for younger members of Generation X and older Millennials, but in the most recent few years it has again begun to fall. The younger Millennials - now aged between about 25 and 30 - have the lowest number of children by age 25 ever observed in this country. These trends will partly owe to having children later rather than fewer children in total. But childbearing cannot indefinitely be compressed into later and later ages without downward effects on total fertility.

\footnotetext{
${ }^{5}$ The UK has a far higher average time spent commuting than most other European nations and the US (OECD, 2021a); these high average commuting times 'reflect inefficiencies in spatially aligning housing demand and supply and are a measure for many citizens' difficulty to move close to the centre of economic and social activity, often due to unaffordable housing in these areas' (ibid.: 77).
} 
Figure 1.2 Fertility across the generations.

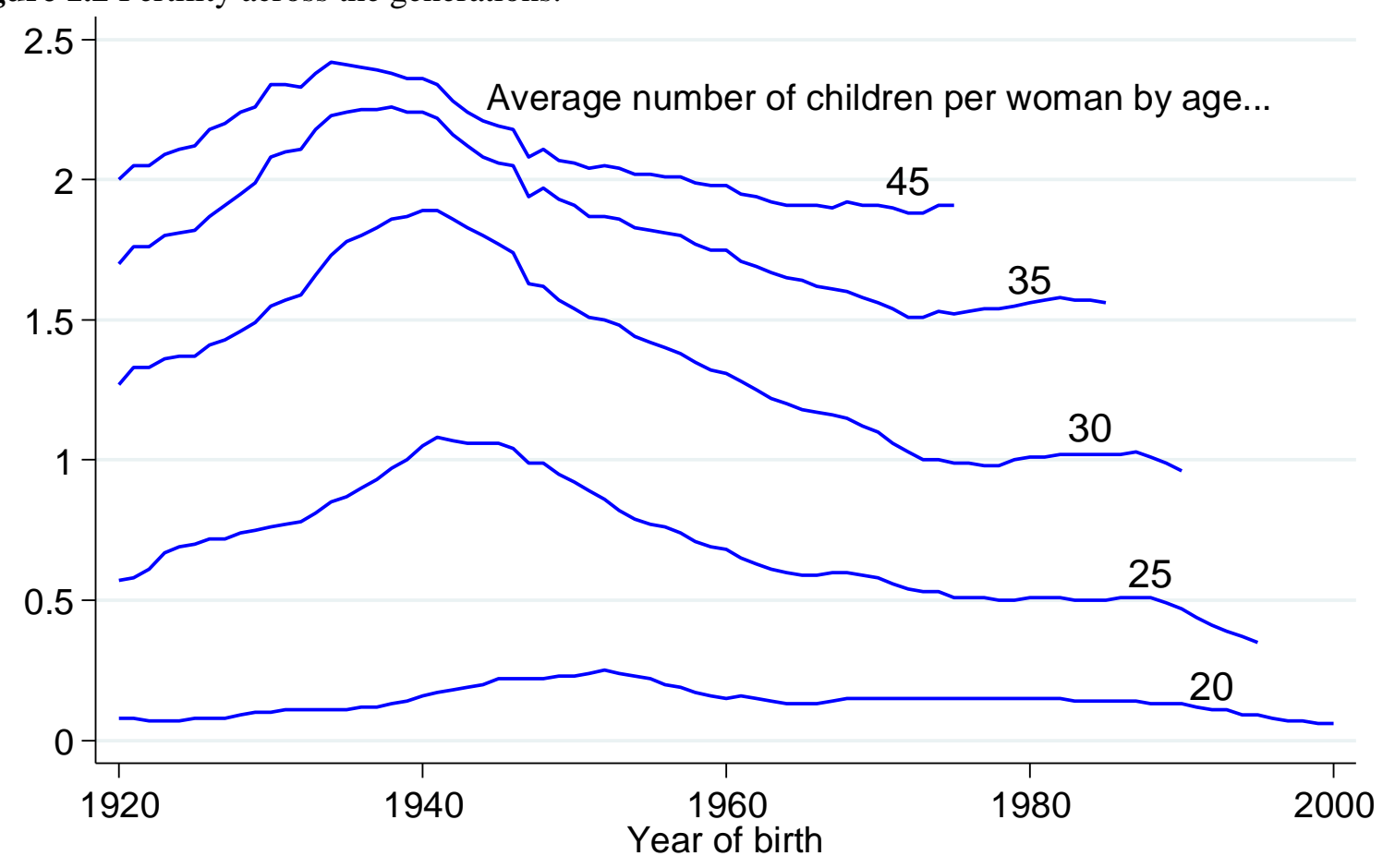

Source: adapted from ONS (2020) 'Childbearing for women born in different years'. This data is licensed under the Open Government Licence v3.0.

Many factors influence the decision to have children, but research is increasingly linking house price rises to lower fertility among renters (Aksoy, 2016; Washbrook, 2013). Prospective parents are sensitive to the costs of finding housing with enough space. Squeezed incomes and dampened economic prospects also deter them. There is also of course the high cost of childcare, on which a dual-earner couple with average wages would now expect to spend $29 \%$ of their net household income, compared with an average of $13 \%$ across the OECD (a group comprising most developed, high-income countries) (Farquharson, 2021).

\section{The opportunity: seniority, time, expertise, and wealth}

A core proposition of The Future is Bright is that members of older generations are in a prime position to offer opportunities and help pass on knowledge to young people today. The charity places an emphasis on individual action, and calls upon those who are able to put their resources to use, particularly members of older generations who may hold senior positions within organisations, who have accrued skills and experience, who are at or close to retirement age and may have newly free time, or who are at liberty to influence the direction of investment, large or small. The concluding chapter includes some broad suggestions in light of the report's findings.

To make more concrete the theme running through this chapter that older generations collectively hold an unprecedentedly great amount of wealth, I end this introduction by taking a quick look at how wealth is distributed across the generations. Table 1.2 gives a breakdown of the total net wealth held by different cohorts, based on the Office for National Statistics (ONS) Wealth and Assets Survey. It is likely, of course, that wealth has always been disproportionately concentrated among the older parts of the population, and it is no surprise to see that picture emerge here. At the same time it is striking that those born between 1946 and 1965 hold $£ 7.4$ trillion in private wealth, well over half of the total held 
by British residents. Those born before 1970 hold $84 \%$ of the nation's private wealth, totalling $£ 11.5$ trillion. ${ }^{6}$

Table 1.2 also shows how this wealth is distributed across asset classes. Most private wealth is tied up in private pensions and in individuals' main properties. But a substantial portion consists of financial wealth (savings accounts, stocks, bonds, etc.) and additional property wealth - mostly buy-to-lets and second homes. These can more easily be liquidated and reinvested. Baby Boomers alone hold approximately $£ 1.25$ trillion in these two classes of assets, of which approximately $£ 400$ billion is in additional property wealth.

Table 1.2 Total net wealth of British residents in 2014-16, by birth cohort and asset type.

\begin{tabular}{|c|c|r|r|r|r|r|r|}
\hline Born & $\begin{array}{c}\text { Age in } \\
\mathbf{2 0 1 5}\end{array}$ & $\begin{array}{r}\text { Main } \\
\text { property }\end{array}$ & $\begin{array}{c}\text { Additional } \\
\text { property }\end{array}$ & Pension & Financial & Physical & Total \\
\hline & & & & $(£$ billions $)$ & & & \\
\hline $1991-1995$ & $20-24$ & 5 & 4 & 9 & -1 & 60 & 77 \\
\hline $1986-1990$ & $25-29$ & 38 & 15 & 37 & 15 & 64 & 168 \\
\hline $1981-1985$ & $30-34$ & 102 & 34 & 121 & 25 & 94 & 376 \\
\hline $1976-1980$ & $35-39$ & 204 & 36 & 199 & 48 & 92 & 579 \\
\hline $1971-1975$ & $40-44$ & 287 & 49 & 343 & 76 & 114 & 871 \\
\hline $1966-1970$ & $45-49$ & 391 & 81 & 581 & 116 & 124 & 1,293 \\
\hline $1961-1965$ & $50-54$ & 459 & 90 & 837 & 159 & 125 & 1,670 \\
\hline $1956-1960$ & $55-59$ & 482 & 97 & 1,022 & 216 & 119 & 1,937 \\
\hline $1951-1955$ & $60-64$ & 495 & 95 & 969 & 229 & 124 & 1,912 \\
\hline $1946-1950$ & $65-69$ & 547 & 105 & 842 & 255 & 131 & 1,880 \\
\hline $1941-1945$ & $70-74$ & 403 & 100 & 439 & 272 & 99 & 1,312 \\
\hline $1936-1940$ & $75-79$ & 284 & 18 & 227 & 121 & 69 & 718 \\
\hline-1935 & $80-$ & 425 & 19 & 178 & 152 & 94 & 869 \\
\hline Total & & 4,122 & 744 & 5,803 & 1,684 & 1,308 & 13,661 \\
\hline
\end{tabular}

Source: ONS Wealth and Assets Survey. Inflated to January 2020 prices. Additional property wealth refers to land and property held in addition to the individual's main residence. Pension wealth refers to private pension wealth and is partly based on ONS estimation of the value of individuals' pension entitlements. Financial wealth refers to formal and informal financial assets, plus the value of certain assets held in the names of children, plus the value of endowments purchased to repay mortgages, less the value of non-mortgage debt. Physical wealth refers to household contents, collectibles and valuables, and vehicles. I have used the 2014-16 data rather than the (latest available) 2016-18 data because age is available only in five-year bands and (reading 2015 for 2014-16) this wave allows a neater correspondence to the birth years traditionally defining the generations.

Individual situations vary, but as a group, older generations are not only rich in the literal sense but also rich in time, expertise, and influence - not to mention political engagement. Contrary to what we often hear, they are in a prime position to change the world for the better.

I now take a closer look at how educational, employment, and housing opportunities in the UK have changed over the last fifty years, and the impact on different generations. A briefer chapter on wealth follows, before a final chapter summarises and concludes.

\footnotetext{
${ }^{6}$ As claims about the situation in 2022 , these numbers are all underestimates to some degree. Since the WAS surveys a representative sample of households, it is very likely to miss the extremely wealthy, some of whom individually hold tens of billions and who are also mostly older. These estimates therefore slightly underestimate the concentration of wealth among older generations relative to younger. Further, household wealth has increased substantially since these data were collected, to a total of $£ 15.2$ trillion (2018-20 data; note that at time of writing the 2018-20 underlying microdata that would allow this to be broken down by generation have not yet been released), with further increases through the pandemic despite a brief early shock (Leslie \& Shah, 2021). There is no reason to think the generational distribution of this wealth has changed substantially since the data presented in Table 1.2 were collected in 2014-16.
} 


\section{Education and skills}

This chapter looks at how the education system has changed across the generations. I pay particular attention to the expansion of higher education - the change which most prominently distinguishes different generations' experience of education - but also discuss education spending and student finance, teachers' pay and conditions, the restructuring of secondary education, private tuition, social class inequality, and the question of whether standards have improved, both in school and among the working age population.

Figure 2.1 Highest qualification (at age 25-30), by sex and birth cohort (\%).

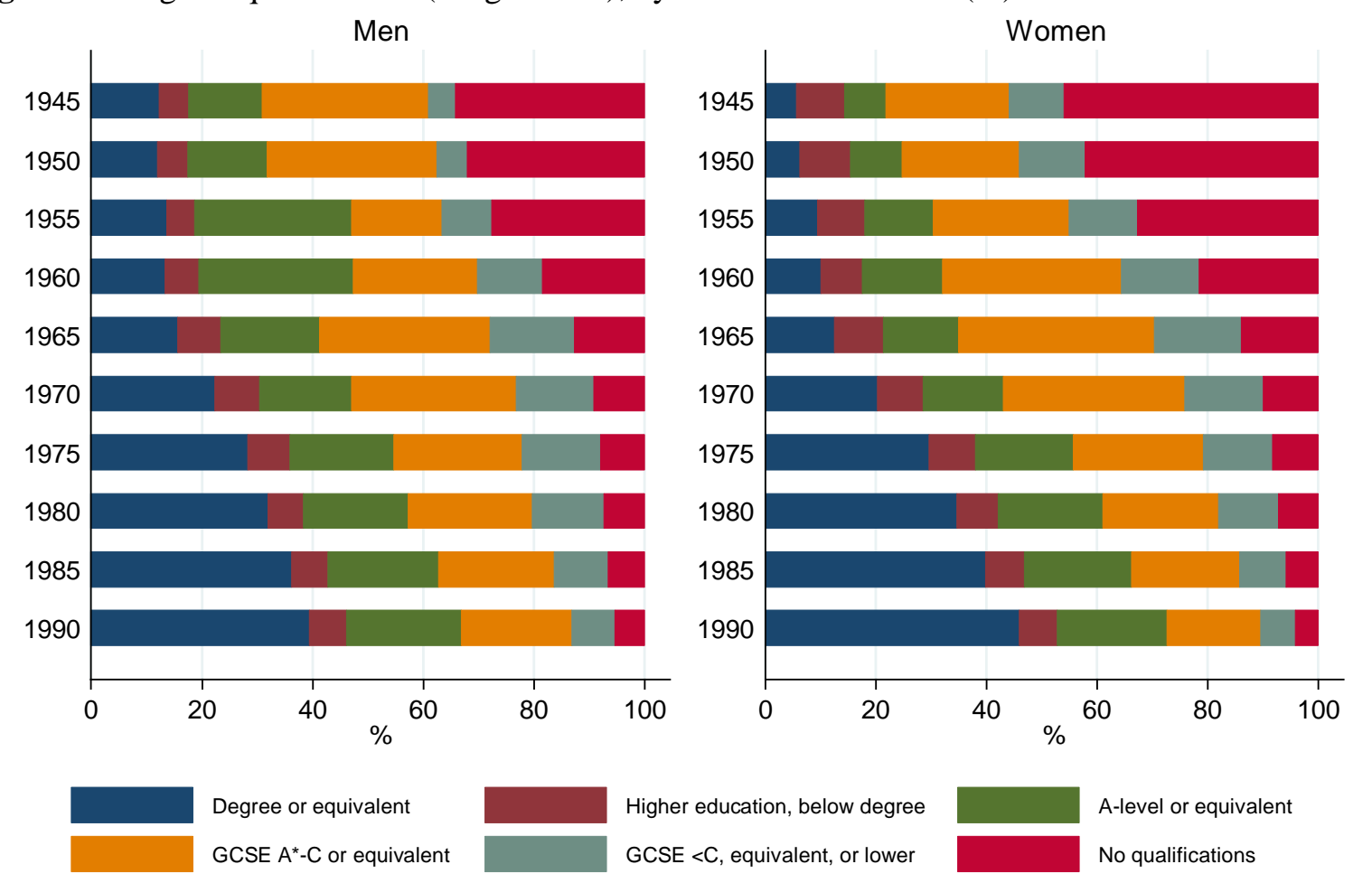

Source: ONS, Labour Force Survey 1979-2020. 1945: born 1945-1949, etc. Equivalences between qualifications (e.g. A-level and level 3 NVQ) are nominal and are detailed in the LFS documentation available from the UK Data Service. They approximately follow the schema outlined at: https://www.gov.uk/what-different-qualification-levels-mean.

\section{Educational expansion and academicisation}

The defining trend in education over the past half-century has been educational expansion. This pattern encompasses growth in the proportions of schoolchildren gaining qualifications, continuing beyond compulsory schooling, and entering higher education. This expansion has gone hand in hand with what some have called 'academicisation' - an increasing emphasis on the academic over the vocational.

Figure 2.1 shows how the proportion holding each nominal level of qualification (at ages 25-30) has changed across birth cohorts. About $15 \%$ of Baby Boomers completed a degree or equivalent qualification by age 30 , whereas the figure among Millennials is closer to $40 \% .^{7}$ Figure 2.1 also shows

\footnotetext{
${ }^{7}$ You will see sometimes quite divergent numbers depending on exactly what is being measured and the data source. There are a variety of ways to get at the basic idea of the proportion of a cohort that 'go to university' or similar. Estimates might differ depending on the treatment of different courses and institutions (such as further education colleges, independent training providers, and polytechnics when considering older cohorts), whether only those who enter at 18 are counted, whether enrolments or completions are counted, and whether the measure includes an element of projection into the future. By one measure, the Higher Education Initial Participation
} 
that over the course of this expansion, the gender gap in educational attainment has declined and indeed reversed. Among the younger cohorts, women are slightly more educated than men on average.

I will only mention a few of the most important milestones in this process of expansion, covering first school and then higher education. The school leaving age was raised to 16 in 1972, adding a year of education for the estimated 25\% of the cohort who otherwise would have left (Clark \& Royer, 2013). At this point, O-level exams were still only taken by a minority. This changed when the 1988 Education Reform Act introduced GCSEs, to be taken by almost all 16 year-olds. Most students began to sit for at least some kind of academic qualification. The Education and Skills Act 2008 now mandates staying in (either full- or part-time) education or training until age 18. Meanwhile from the 1970s onward, traditional work-based apprenticeships fell into decline and a patchwork of often low-quality vocational programmes within the educational system took their place (Augar et al., 2019; Wolf, 2011).

There have been two major waves of new universities, first in the 1960s and then in the early 1990s (Figure 2.2) ${ }^{8}$ Limits on the number of students these universities can take were abolished in 2015, except for a handful of subjects including medicine and dentistry (Norton, 2020). Universities are currently incentivised to admit as many students as possible, as they are primarily funded on a perstudent basis through tuition fees at a flat rate. ${ }^{9}$

Figure 2.2 Higher education enrolment rate (\%).

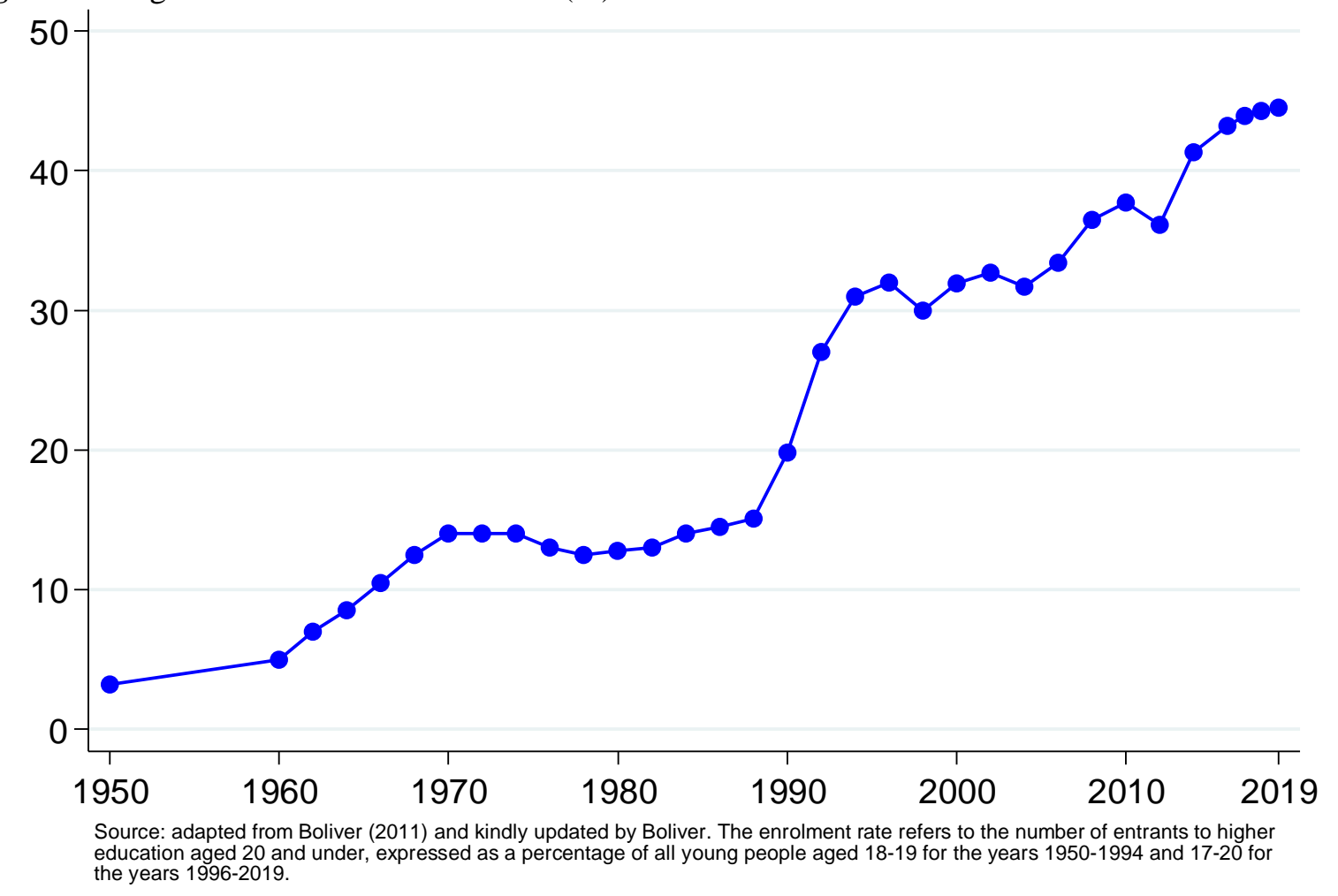

measure for England ('with additional providers'), Tony Blair's famous 50\% target was passed in the 2015-16 academic year.

${ }^{8}$ These two waves of expansion differ in important ways but also mainly represent existing institutions being granted university status, in particular large numbers of polytechnics in 1992 through the Further and Higher Education Act. For further detail see for instance Boliver (2011), Goodhart (2020), Lambert (2019), or Woodward (2019).

${ }^{9}$ Notionally tuition fees are variable (to promote competition on price), but in practice almost all courses charge the maximum allowed level. 
This expansion has shaped the experience of younger generations in some fundamental but perhaps subtle ways. In this report I would ideally stick to easily-interpretable measures which one can plot on a graph and use to compare how different generations are faring. But the costs and benefits of educational expansion are not so easy to pin down in this way.

There are different ways of looking at what this educational expansion means. Lots of people feel quite passionately that higher education has an intangible intrinsic value, and the more people get to enjoy this, the better. Going a little further, they might also argue that education has 'non-economic' benefits such as increased empathy, civic engagement, and healthy behaviour - one encounters new ideas and unfamiliar viewpoints by leaving home and studying for three years. In economic terms, proponents of more education can point to a fairly persistent graduate premium in earnings (Blundell et al., 2016; Britton et al., 2020a). There is also evidence that analytical skills are becoming more important across all sections of the workforce (Dickerson \& Morris, 2019), suggesting that it is worthwhile to continue to develop them through education.

One could also take issue with many of these supposed advantages. Those non-economic benefits are very difficult to assess and in many cases appear quite small (Bynner et al., 2003; Davies et al., 2019; Heath, 2018). We ought not to dismiss out of hand the challenge of proving that the presumed benefits of higher education are real and would not have happened anyway as those same people matured into young adulthood. We could also consider what alternatives are possible at a much lower cost - not going to university need not preclude other sorts of edifying pursuits. ${ }^{10}$ As for a graduate premium, this is, paradoxically, entirely consistent with education not actually making people more productive. And while analytical skills may indeed be of growing importance throughout the economy, research has struggled to document effects of education on supposedly transferable skills like critical thinking (Arum \& Roksa, 2011; Caplan, 2018).

Further, according to this critical view, higher education is costly, barely shows any benefit for many students in terms of their earnings (or even results in a negative return (Britton et al., 2020a)), adds years to people's adolescence and keeps them from starting their adult lives, and hungrily sucks in ever more students through self-reinforcing cycles of positive feedback, while also failing to deliver on a promise of delivering equality of opportunity and social mobility.

This is a complex and multifaceted debate which I cannot do justice to here, but I will briefly expand on some of the potential drawbacks. I also want to highlight some of the implications for the group often left out here - those who don't enter higher education.

Most of the potential downside of educational expansion boils down to a tricky question: to what extent does higher education make people more productive (as universities will tend to claim it does), and to what extent, instead, does it simply give degrees and recognition to people who would have gone on to be more productive anyway? This second perspective is known as the signalling theory of education: higher education is good for each individual who can get a degree, because it lets them show off to employers that they are smart, compliant, will tolerate boredom in exchange for reward, and so on; but

\footnotetext{
${ }^{10}$ Indeed a transfer of funding away from university libraries (from which it mostly goes to line the pockets of for-profit academic publishers) and back into public libraries and arts institutions could not only continue to nurture intellectual pursuits and knowledge-for-its-own-sake, but also make such activities far more widely available. The 2010 s saw the closure of $18 \%$ of the UK's public libraries amid a $30 \%$ cut in spending (Flood, 2019). The publishers to whom billions of dollars of higher education, research council, and charitable foundation spending goes each year (often at profit margins of 30-40\% (Bradshaw, 2019)) benefit from an extremely dysfunctional system aptly described as 'economic parasitism' (Monbiot, 2011). For short overviews see New Scientist (2018), Schmitt (2015), or pages 4-6 of Kayal et al. (2021); see Buranyi (2017) and Puehringer et al. (2021) for longer journalistic and academic treatments respectively.
} 
for society as a whole, this argument goes, the cost of getting that degree was a waste - the graduate didn't actually learn much of any use.

Unfortunately this is a question to which it is very difficult to give a firm answer. And of course that answer will vary depending on the context - in the clearest case, a doctor needs to have a good knowledge of medicine, and needs to study for this. But some basic considerations align with signalling theory: the vast majority of people do not use in their jobs the vast majority of what they learn, and moreover we forget most of what we learn. Wolf (2002) and Caplan (2018) are among those who make the argument in greater detail.

Figure 2.3 is at least a starting point in allowing one to form an impression of where the balance might fall between productivity-enhancing qualifications and signalling in terms of the expansion of UK higher education. It shows the number of degrees achieved in UK universities in 1995, 2007, and 2019, according to broad subject groupings. I leave it to the reader to ponder the extent to which the growth has been in subjects which tend to truly and substantially enhance the productivity of their students.

Student choice is the main factor determining which subjects have grown and which have not. This has its merits, but obvious drawbacks too. A more strategic and supply-led approach might have yielded more doctors and engineers, for instance. The current funding model incentivises universities to attract students to courses which are relatively inexpensive to run, since tuition fee income is the same for all courses. And as Lambert (2019) argues in a forceful piece, there are only very weak incentives in place for universities to guard academic standards.

Figure 2.3 First degrees obtained in UK Higher Education Institutions, by year.

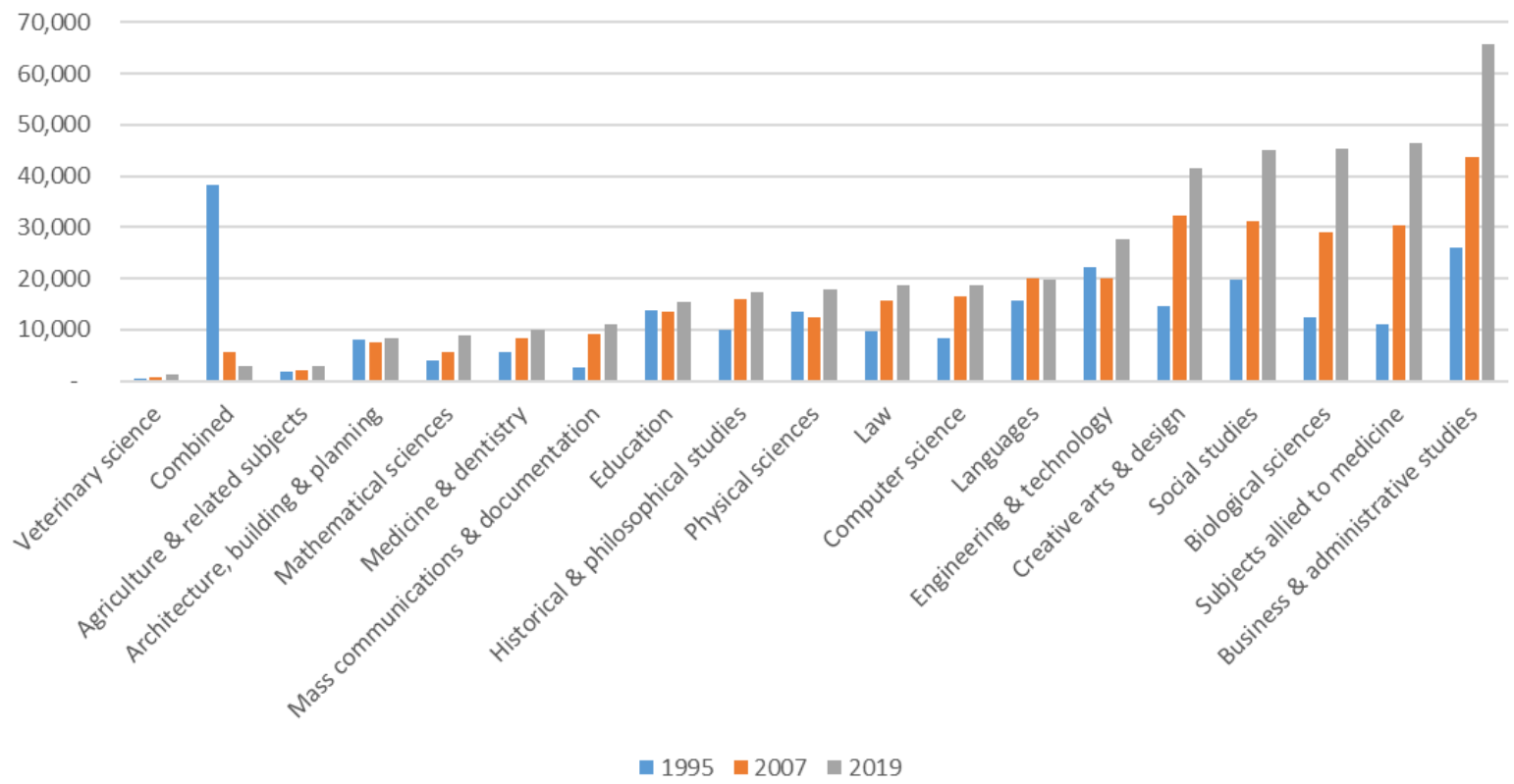

Source: Higher Education Statistics Agency. See https://www.hesa.ac.uk/support/documentation/jacs/hesa-codes for more information on the make-up of each subject group. 'Combined' could mean, for example, mathematics and physics, or French and history.

Goodhart (2020) describes the educational expansion of recent decades as a 'signalling arms race'. This nicely captures the self-reinforcing nature of the process: the more people attain a given level of qualification, the more people are incentivised to also attain it, and indeed to attain a qualification at the next level up. Because of the rising number and level of qualifications held by the average young person, not holding educational credentials looks bad to prospective employers (Wolf, 2011). There is also a self-fulfilling prophecy element to this: if enough people believe that you need a degree to be seen as 
intelligent or 'a success', it becomes true. For any individual faced with these constraints, more education is a rational response.

There is also a possible social mobility cost to educational expansion, contrary to what is often supposed. Faced with a growing pool of competitors who have reached the same educational level, it is disproportionately those from advantaged backgrounds who are able to stay on to the next level in order to distinguish themselves (Raftery \& Hout, 1993). This applies at every level but may be particularly important at the transition from undergraduate to postgraduate study in the contemporary UK: student loans make undergraduate study widely accessible, but there is little funding for postgraduate students who cannot draw on parental financial support. This is an issue researchers are just beginning to explore in detail, but the evidence so far supports this emerging pattern (Wakeling \& Laurison, 2017).

A final drawback of educational expansion is that employers absorb the benefits of the situation in a way that detracts from their longstanding role as potential avenues for advancement outside the educational system. Organisations are incentivised to increase the minimum educational requirements for roles, and disincentivised both from making their own assessments of school leavers - including 'taking a chance' on prospective employees - and from training them up. The education system will do the sorting and take the risk for them. And as the stated educational requirements of roles rise, so too must the demand for education.

In sum then, recent generations have gone through a much longer educational career involving many more examinations than their predecessors, to questionable benefit. Some will have enjoyed this, many will have endured it while looking forward to eventually 'starting their lives' by entering adulthood and the workplace.

Reflecting on these trends, Goodhart (2020) argues that a fundamental shift has taken place: we are in a new 'era of educational selection' in which access to desirable employment and opportunities for advancement are now chiefly determined by one's educational credentials, and much more so than for older generations. ${ }^{11}$ Goodhart suggests that many schoolchildren faring badly in this regime of academic selection 'will already regard themselves as failures'. I am not aware of research directly testing this. But it certainly chimes with the finding from the latest PISA survey that only 53\% of UK 15-year-olds rated their life satisfaction at seven or higher out of ten, compared with an OECD average of $67 \%$ (Mostafa \& Schwabe, 2019). Of course this is only suggestive. Life satisfaction is influenced by a wide variety of factors. Whatever the reasons behind this, it is a concerning figure.

This idea of an era of educational selection can be illustrated by looking at the educational requirements for 'high-skilled' employment (Figure 2.4). In 2017, 55\% of survey respondents in these mostly managerial and professional occupations said that if someone were applying for their job, they would need to have a degree, up from $29 \%$ in 1987. In earlier years, a degree might have been an advantage

\footnotetext{
${ }^{11}$ A seemingly positive implication one might initially draw is that this indicates a growing degree of meritocracy. Not only have the desirability of such a regime and even the coherence of meritocracy as an idea been powerfully questioned recently (Frank, 2016; Goodhart, 2020; Markovits, 2019; Mijs, 2016; Sandel, 2020), a strengthening of the link between education and class destination does not on its own tell us much about meritocracy. One reason is that strong links remain both between social background and educational attainment (touched on later in the chapter) and between social background and class destination independent of education (Bukodi \& Goldthorpe, 2019; Friedman \& Laurison, 2019). Another is that education is a questionable indicator of 'merit'. A simpler and yet deeper problem is that of whether 'meritocracy' makes any sense: 'opportunities for merit are themselves determined by non-meritocratic factors' (Mijs, 2016: 14) such as where, when, to whom, and with what sort of characteristics you were born.
} 
but not a necessity, and one might have proved oneself at a lower level within an organisation before achieving promotion into senior roles. ${ }^{12}$

Figure 2.4 Percentage of high skill jobs requiring a degree.

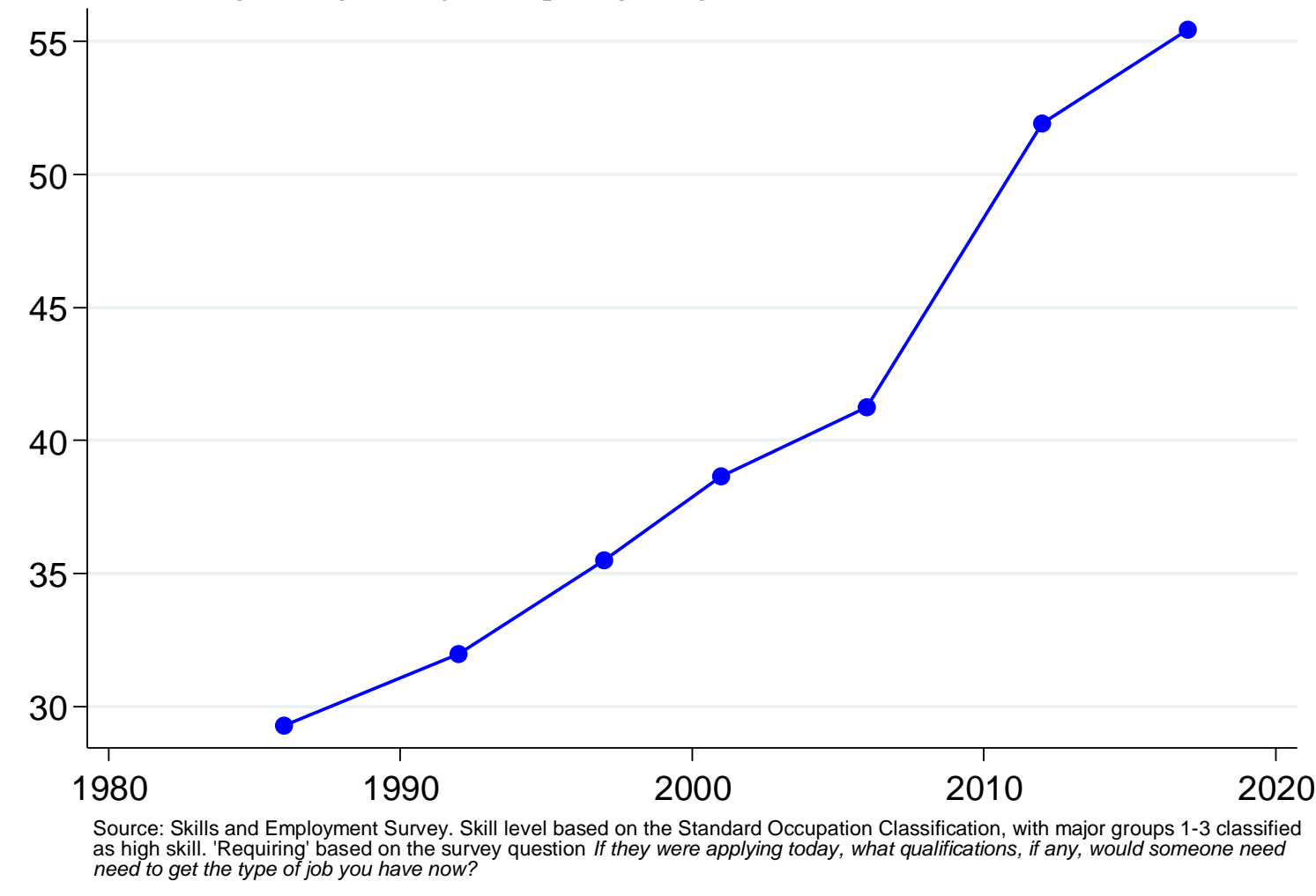

\section{The vocational route}

So what about a vocational or technical education? Older generations enjoyed a credible vocational route for those who did not go on to further academic study. With the decline of manufacturing, the endless 'policy churn' of new vocational systems replacing one another (Norris \& Adam, 2017: 5), and the expansion of higher education, however, the vocational sector has atrophied, leaving a confusing array of courses which are often untrusted by employers and not well understood by potential students (Augar et al., 2019). The influential 2011 Wolf Report on vocational education for 14-19 year-olds criticised the 'sclerotic, expensive, centralised and over-detailed approach that has been the hallmark of the last two decades' (2011: 11). The Richard Review found that the system of apprenticeships in place from the mid-1990s was not responsive to the needs of employers or the labour market, was concentrated at lower qualification levels, often did not involve any training, and in many cases represented existing employees being certified for jobs they already did (Richard, 2012). A Department for Education report found that in the mid-2010s, about a third of apprentices were not even aware that they were apprentices (IFF Research, 2017).

Attempts to improve the system are currently being undertaken, but the current situation is undoubtedly one where the academic route is seen as the default and many vocational qualifications are viewed with suspicion. A recent House of Lords report held that decades of policymaking had focused on those

\footnotetext{
${ }^{12}$ With regard to cohorts born in 1946, 1958, and 1970, Bukodi and Goldthorpe (2019) show that there has not been a substantial strengthening of the link between educational attainment and class destination - though the link is stronger for these cohorts than those born across the first half of the twentieth century. However I am not aware of any studies comparing the strength of this link between those born in 1970 and later cohorts, on whom Goodhart's argument appears to focus.
} 
going on to higher academic study on the one hand, and those at risk of falling out of the labour market altogether at the other, leaving an 'overlooked', 'forgotten' majority in the middle (Select Committee on Social Mobility, 2016: 13). It is telling that spending per student on upper secondary vocational programmes was $33 \%$ lower than on general (academic) programmes in the UK in 2017, whereas it is higher in most other OECD countries (OECD, 2020).

There is a palpable contrast with older generations in all this - countless individuals left school with no qualifications but have gone on to achieve a great deal, showing that not having academic qualifications per se says nothing about one's potential. What is important is the context within which one has no academic qualifications.

In the next chapter I will touch further on the labour market, a major factor in people's decisions about how far to take their education. For the moment, it is sufficient to say that limited employment opportunities for teenagers, a polarisation of the labour market into high- and low-quality jobs, a poorlyresourced and confusing vocational offering, and a higher education system with few barriers to entry are the most salient characteristics of the current situation, and all represent a contrast with the experiences of Baby Boomers. It is in the context of an increasingly competitive market for non-lowpaying jobs that young people are increasingly turning to higher education to improve their position.

\section{Education spending and student finance}

The education system has seen a large increase in real-terms funding up to 2010 and substantial cuts since then, as shown in Figure 2.5 (Bolton, 2020). This funding increase is perhaps unsurprising in light of the educational expansion described above. But it goes beyond the cost of more years of education at the same rate. For instance, per-student funding in primary and secondary education almost doubled in real terms between 1997-98 and 2015-16 (Belfield et al., 2018).

Figure 2.5 UK public spending on education as \% of GDP and in $£$ billions, 2019-20 prices.

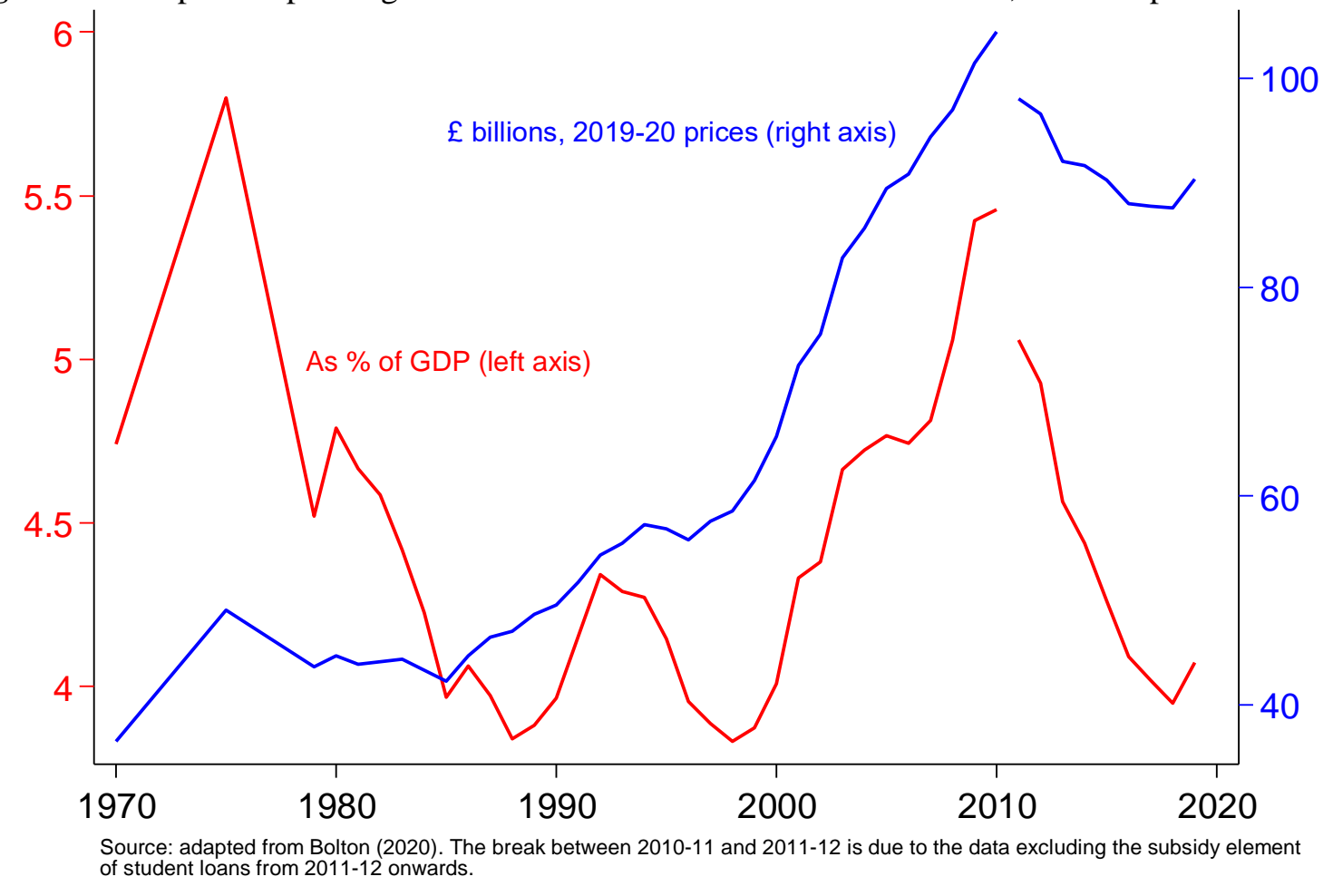


Figure 2.6 Education spending per pupil/student, by stage (US dollars).

\section{(a) Early childhood}

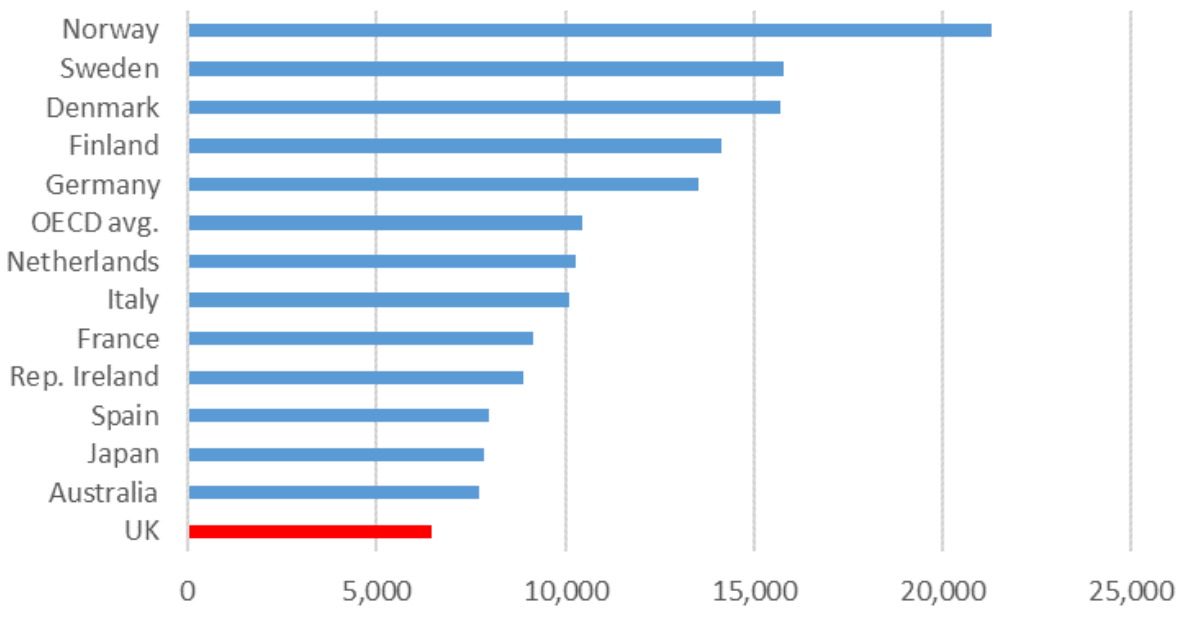

(b) Primary to post-secondary non-tertiary

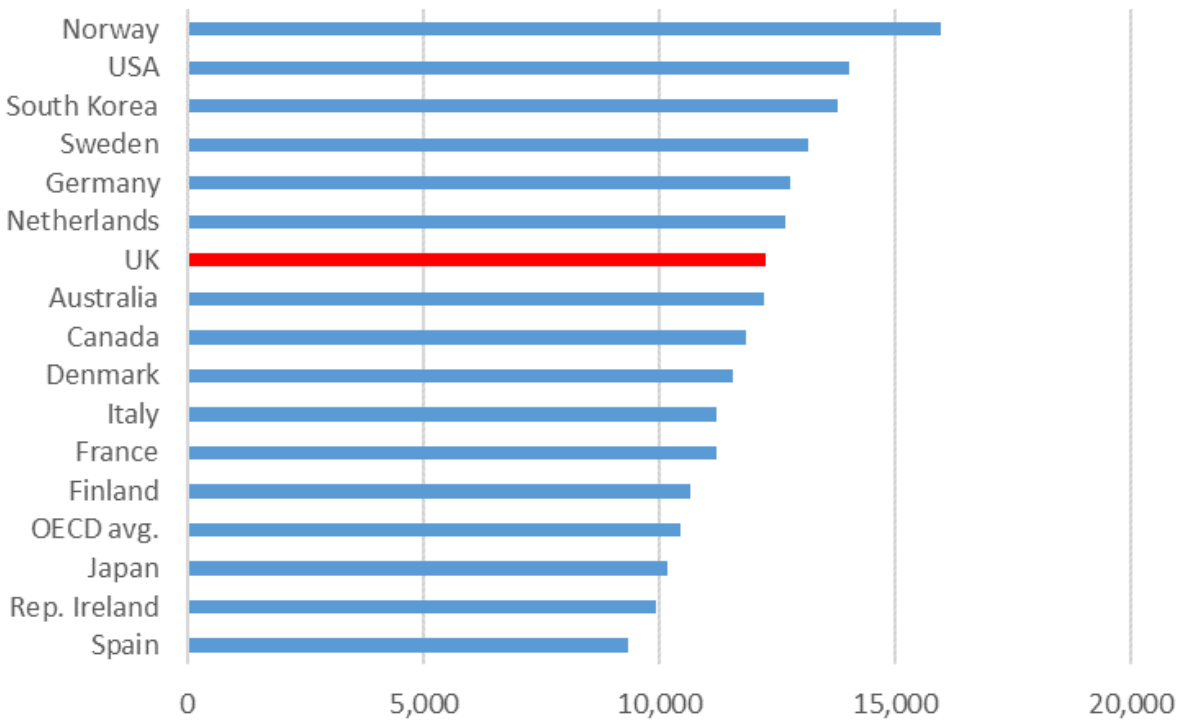

(c) Tertiary

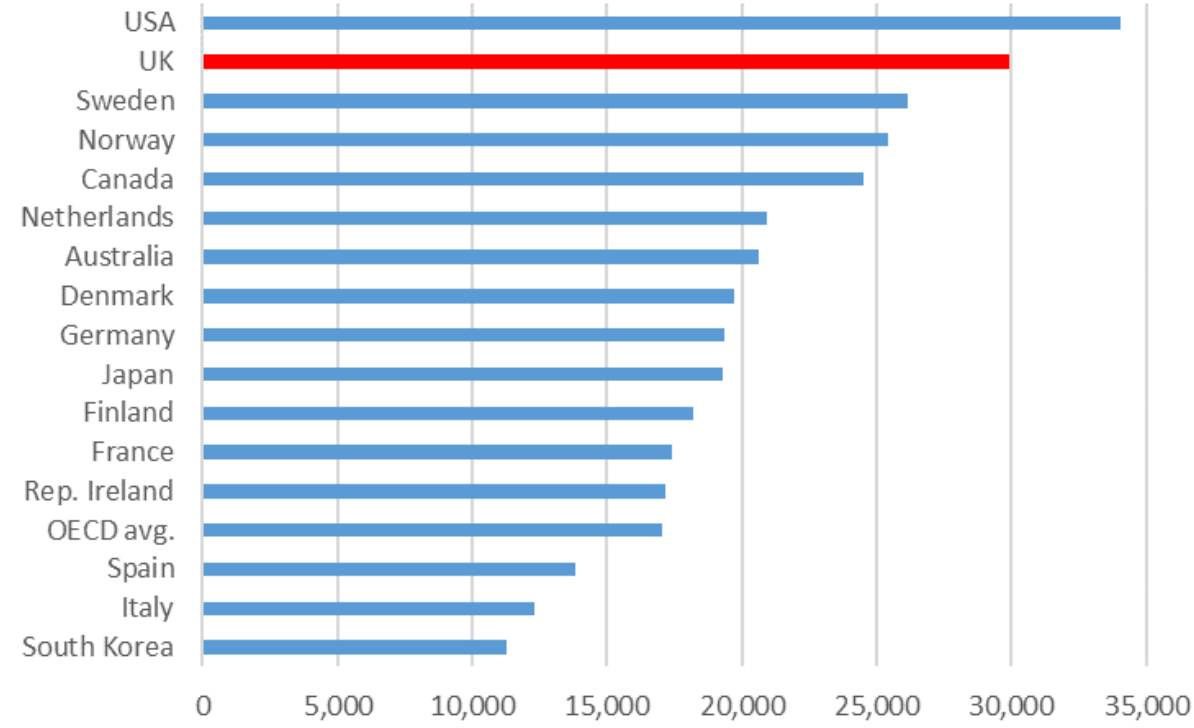

Source: OECD (2021b). Data from 2018. Includes public and private spending. Data for (a) unavailable for USA, Canada, and South Korea. 
Where have the cuts since 2010 fallen? The past decade has seen real-terms cuts of $9 \%$ to per-pupil school spending in England, 12\% to per-student spending in further education and sixth-form colleges, and 35\% to total spending on adult education and apprenticeships (Britton et al., 2020b). A further pattern of note is that although per-pupil spending is higher for schools in more deprived areas, these schools have also experienced the largest cuts since 2010 (Sibieta, 2021).

It is probably wise that funding has started to gradually move away from a model with successively much more funding per student at each stage from early years to higher education (Belfield et al., 2018). Research suggests that the benefits to individual students and to society from educational spending are far greater at earlier ages (Heckman, 2006). ${ }^{13}$ However spending per student remains far lower in the early years than at the primary, secondary, further, and higher levels of education (Belfield et al., 2018). Early years spending is also low compared with other countries, as shown in Figure 2.6. By contrast, the UK (with the USA) is an outlier in terms of its high per student higher education expenditure.

An important difference between spending on higher education and all earlier stages is that, at least in theory, most higher education is funded through fees paid by the students themselves, financed by a government student loan scheme. These tuition fees were introduced in 1998. In England, the maximum fee was increased for students beginning their courses in 2006, and then again in 2012.

One sometimes hears statements about younger generations being 'burdened' by student debt following the introduction of tuition fees. While it is true that higher education was free to students in earlier years whereas tuition fees impose a cost, the actual burden on students is often considerably overstated. Student loans (for tuition and living costs) make higher education free at the point of use, and are only repayable when graduates are earning above a threshold currently set at $£ 27,295$, making it a de facto graduate income tax rather than student debt. $9 \%$ of income above this level is taken in repayments so about $£ 28$ per month for a graduate earning $£ 31,000$. And zero for anyone earning less than $£ 27,295$. The relatively high interest rate only has the effect of extending the period over which higher-earning graduates continue to pay this $9 \%$. Any remaining balance is written off after 30 years. ${ }^{14}$

This is a very different picture from the US, for instance, where student loans are given on similar terms to other personal finance and carry similarly large risks. Unfortunately, the perpetuation of misconceptions surrounding student finance seems to be a factor discouraging potential students from low-income backgrounds from participating in higher education (Callender \& Mason, 2017).

The latest estimate from the Office for Budget Responsibility and Department of Education is that about half of student debt will not be repaid (Bolton, 2021a). This is a substantial sum: 'The value of outstanding loans at the end of March 2021 was $£ 160$ billion. The Government forecasts [this to] reach around $£ 560$ billion (2019-20 prices) by the middle of this century' (Bolton, 2021b: 5). This raises another potential downside to the expansion of higher education - its public cost. As the average student entering university becomes marginally less academically able, it is plausible that they are also likely to pay off a lower percentage of their loan, thus increasing the subsidy rate. The IFS estimates, on average, a very large net positive return to higher education - $£ 750,000$ for men and $£ 390,000$ for women in total over their lifetime, shared between the taxpayer and the individual (Britton et al., 2020a). But such estimates assume that graduates earn more than broadly similar non-graduates due solely to education increasing their productivity. As we have seen, this is a very strong assumption.

\footnotetext{
${ }^{13}$ For a brief review of the research on this topic and an empirical critique, see Rea and Burton (2020).

${ }^{14}$ The details differ slightly depending on circumstances - in particular the repayment threshold is lower for those who began their courses before 2012. https://www.gov.uk/guidance/terms-and-conditions-of-student-loans provides a clear guide.
} 


\section{Teacher pay and conditions}

Attracting and retaining good teachers is crucial for the success of an education system, so it is worth spending a moment to look at trends in their pay and conditions. The influx of resources illustrated above is reflected in increases in real-terms pay from 1975 to 2008 that went ahead of other public sector employees and broadly kept pace with the private sector (Bolton, 2008). However the trend in England since 2007 has justly been dubbed 'The long, long squeeze on teacher pay': even while average earnings only increased $0.6 \%$ across the whole economy from 2007 to 2021, real-terms pay fell by around $4-5 \%$ for new and less experienced teachers, and by $8 \%$ for more experienced teachers (Cribb \& Sibieta, 2021).

Also concerning is the intensification of teaching. Figure 2.7 shows this trend across a number of survey questions asked consistently between 1992 and 2017. In the latest data, more than nine in ten teachers report that the job requires them to work very hard, a figure that compares with 'only a half of workers in other professional jobs, and with 44\% for the whole population' (Green, 2021: 398). Green goes into more detail and shows that while teachers have good job security and their hours have not notably increased, 'most facets of teacher job satisfaction have fallen since 2006' (2021: 399).

Figure 2.7 School teachers (state sector) reporting high work intensity, various measures (\%).

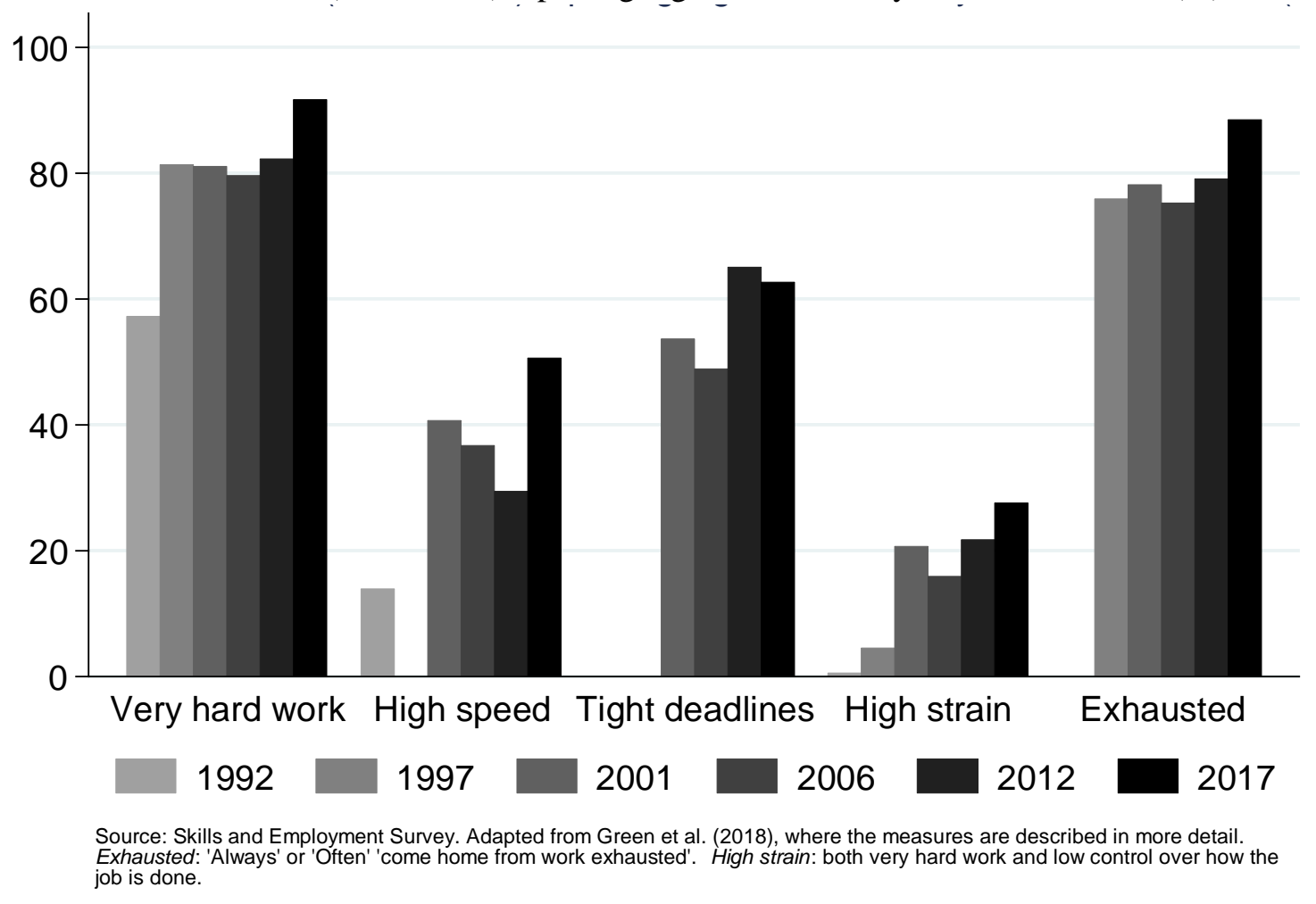

\section{Restructuring}

There have been a number of notable reforms to the structure and governance of the secondary school system. These include, first, the abolition of the tripartite system of grammar schools, technical schools, and secondary moderns between the mid-1960s and mid-70s, and their replacement with comprehensives. Reform was implemented faster in some areas than others, and indeed grammars still remain in some pockets of the country. This has allowed researchers to examine the effects of the 
different systems on social mobility, a topic of perennial interest. Using census data, Buscha et al. conclude that neither system 'had any notable effect on intergenerational social class mobility' (2021: 27). A small minority were enabled by a grammar school education to achieve long-range upward mobility, but their positive experiences are only part of the picture: 'we hear much less often from the corresponding group of people who did less well in a secondary modern than they would otherwise have done in a comprehensive school' (ibid.).

Until the late 1980s, education policy was largely hands-off, overseen by local education authorities and with teachers allowed a high degree of autonomy. Then a more top-down, managerialist approach was introduced with the 1988 Education Reform Act. This established OFSTED, league tables, and Standard Assessment Tests at ages 7, 11, and 14, and introduced an element of parental choice into school admissions. Funding, in turn, was linked to a school's number of students. A major provision of the 1988 Act was the National Curriculum (NC), which prescribed a mandatory set of subjects (with mathematics, English, and science at the 'core'), attainment targets, programmes of study, and assessment arrangements.

A trend from recent years marks something of a reversal of the standardisation imposed by the NC: the introduction and growth of academies (in England only), state-funded schools which operate independently of local education authorities and may set their own curriculum, among other freedoms. This has proceeded in two stages, with a smaller initial group of 203 'sponsored' academies formed under the 1997-2010 Labour government and a much larger number formed after the 2010 Academies Act - indeed the majority of secondary schools and over a fifth of primary schools now have academy status.

The small initial group consisted of takeovers of poorly-performing schools by teams of independent co-sponsors such as businesses, religious organisations, and charities; evidence indicates a positive effect on academic performance for this first tranche (Eyles \& Machin, 2019). Post-2010, schools deemed to be failing continued to be taken over in this way. However schools were also enabled to apply to convert to academy status. These 'converter' academies, unlike the sponsored academies, tend to be high-attainment schools serving relatively advantaged catchment areas (Eyles et al., 2018). Early evidence gives no indication that conversion to academy status has improved performance, however, except among those already rated 'outstanding' (Andrews \& Perera, 2017).

\section{Private tuition}

The private tuition sector has become increasingly visible recently. Since this industry is unregulated, there is no official data describing how widespread private tuition is, how many people work as tutors, whether they tend to do so as a full-time job or less regularly, and how any of this has changed over time.

The best currently available data appear to be those collected by the Sutton Trust, surveying both schoolchildren aged 11-16 over a number of years, and teachers from state primary and secondary schools in 2019 (Sutton Trust, 2019). As Figure 2.8 shows, about 27\% of 11-16 year-olds in England and Wales report ever having received private tuition, up from $18 \%$ in $2005.10 \%$ report tuition in the current school year, up from $6 \%$ in 2005. Further data from the same survey point to two main patterns of usage: about half using tuition to help prepare for specific tests such as GCSEs or a school entrance exam, and about half 'to help me with my school work in general'. The use of tuition has likely grown since 2019 , but the scale of this is currently unclear. 
Figure 2.8 11-16 year-olds receiving private tuition, England and Wales (\%).

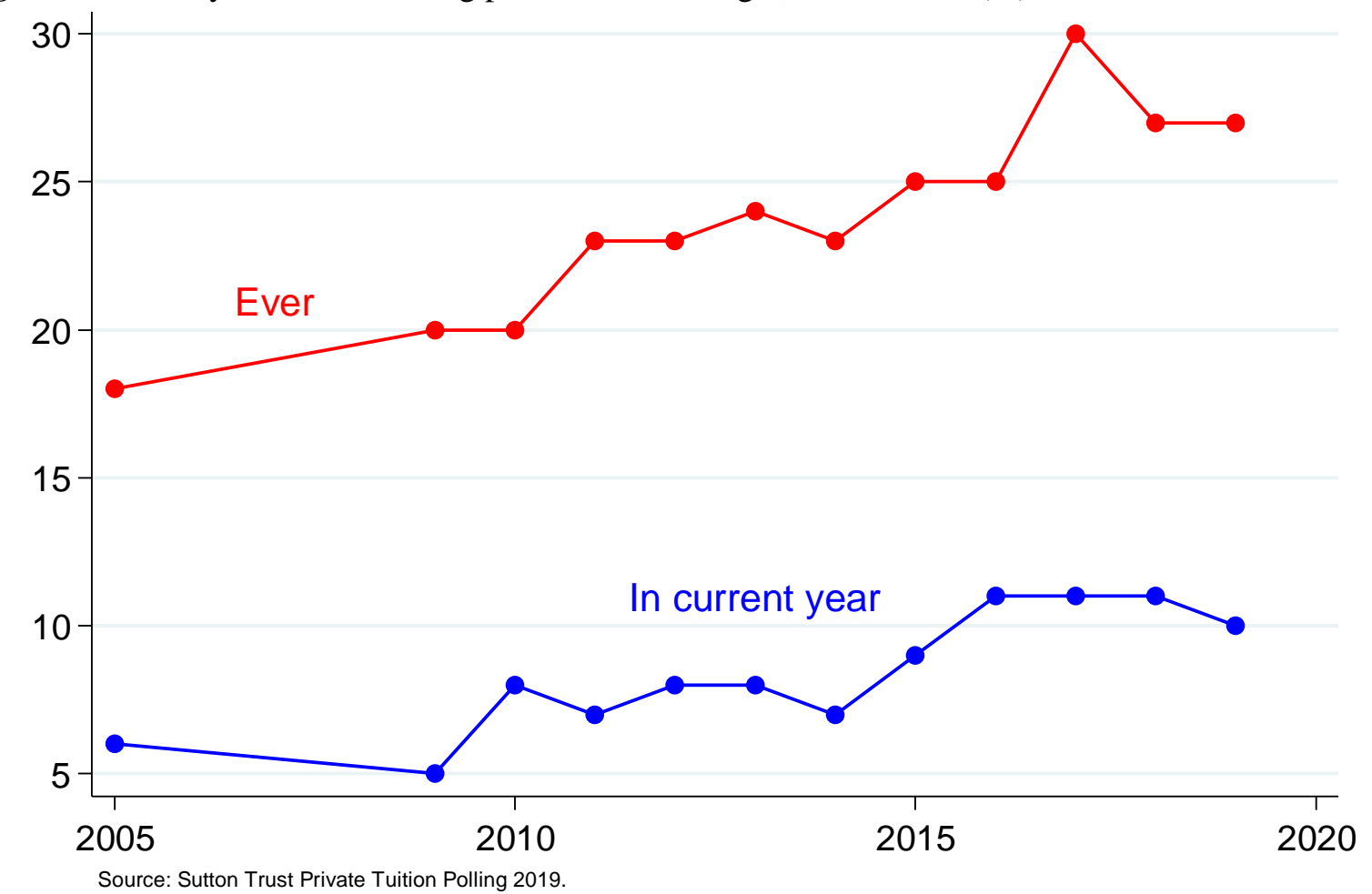

The same Sutton Trust report collected data from teachers for the first time in 2019, and found that 14\% of primary school teachers and $24 \%$ of secondary school teachers reported conducting private tuition in the past two years, mostly 'through direct contact with parents' rather than through an agency. The size, composition, and working patterns of the private tuition agency workforce remains a gap in our knowledge.

The rise of private tuition is an important topic for future research. There are currently shortages of teachers, particularly in science and maths (Worth \& Van den Brande, 2019). It will be important to monitor the extent to which private tuition draws talent away from teaching in state schools, both through full-time employment as tutors, and as teachers devote more of their time and energy to private work to make up for their falling pay.

\section{Social class inequality in education}

While the other sections of this chapter predominantly describe change, social class inequalities in education have remained quite stable.

Although educational expansion has provided more opportunity in some senses - most obviously, more university places - the relative likelihood of students from different social class backgrounds taking advantage does not appear to have changed a great deal. Here I can only begin to touch on the extensive sociological research that examines this issue (Boliver, 2011; Bukodi \& Goldthorpe, 2019; Woodward, 2019), but Figures 2.9 and 2.10 provide some illustration of the pattern, covering different time periods (thanks to gaps in the data) and different parts of the education system. The first of these shows the chances of enrolling in a degree programme at an 'Old' university - that is, the Russell Group and other pre-1992 universities - according to parental social class. Evidently there was little appreciable narrowing of the class-based gaps in admission to these elite institutions across the long and expansionary period between 1960 and 1995 . 
Figure 2.9 Probability of enrolment on a degree programme at an 'Old' university, by class background and enrolment year.

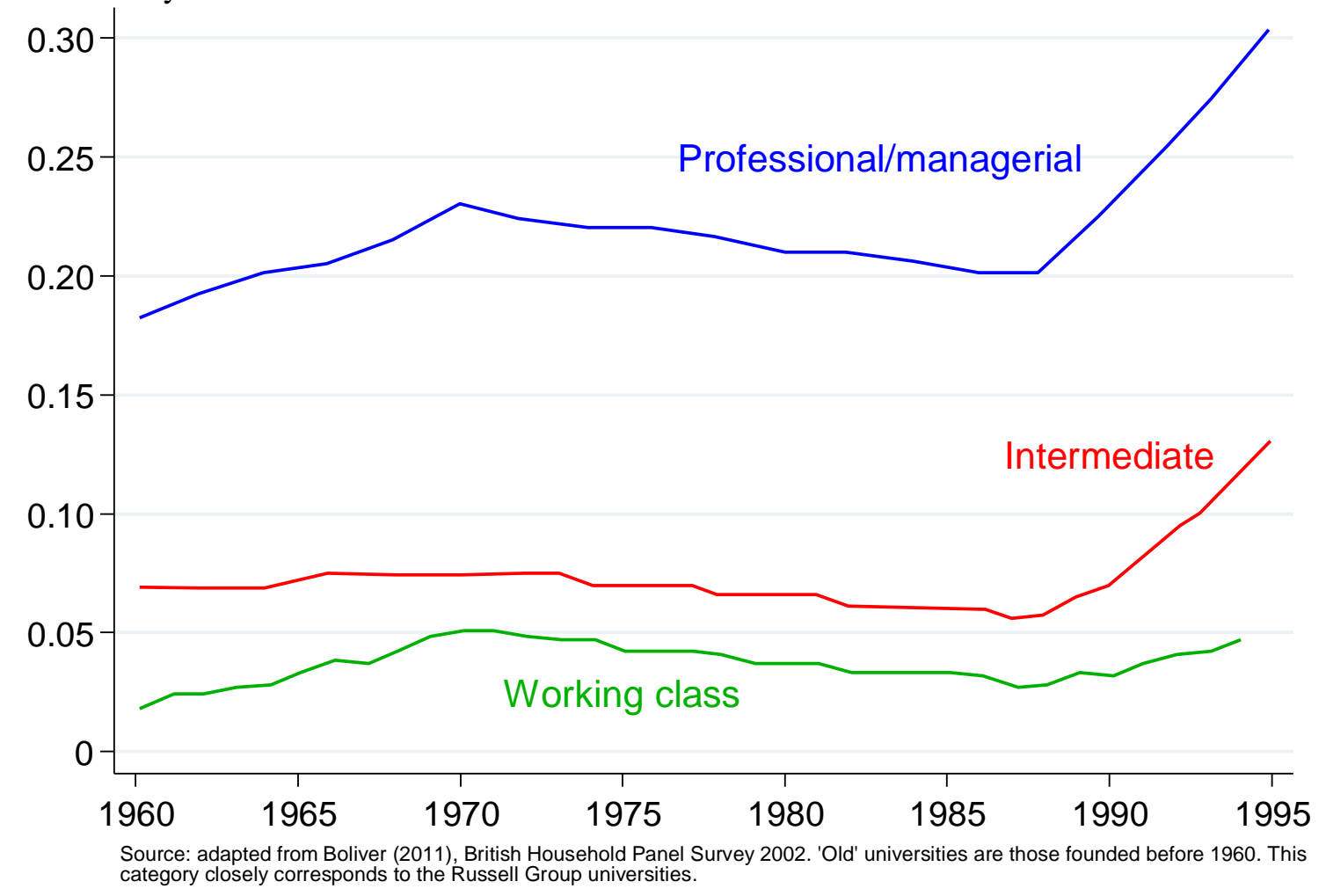

Figure 2.10 17-18 year-olds with five GCSEs at $\mathrm{A}_{-} \mathrm{C}$, by parental social class (\%).

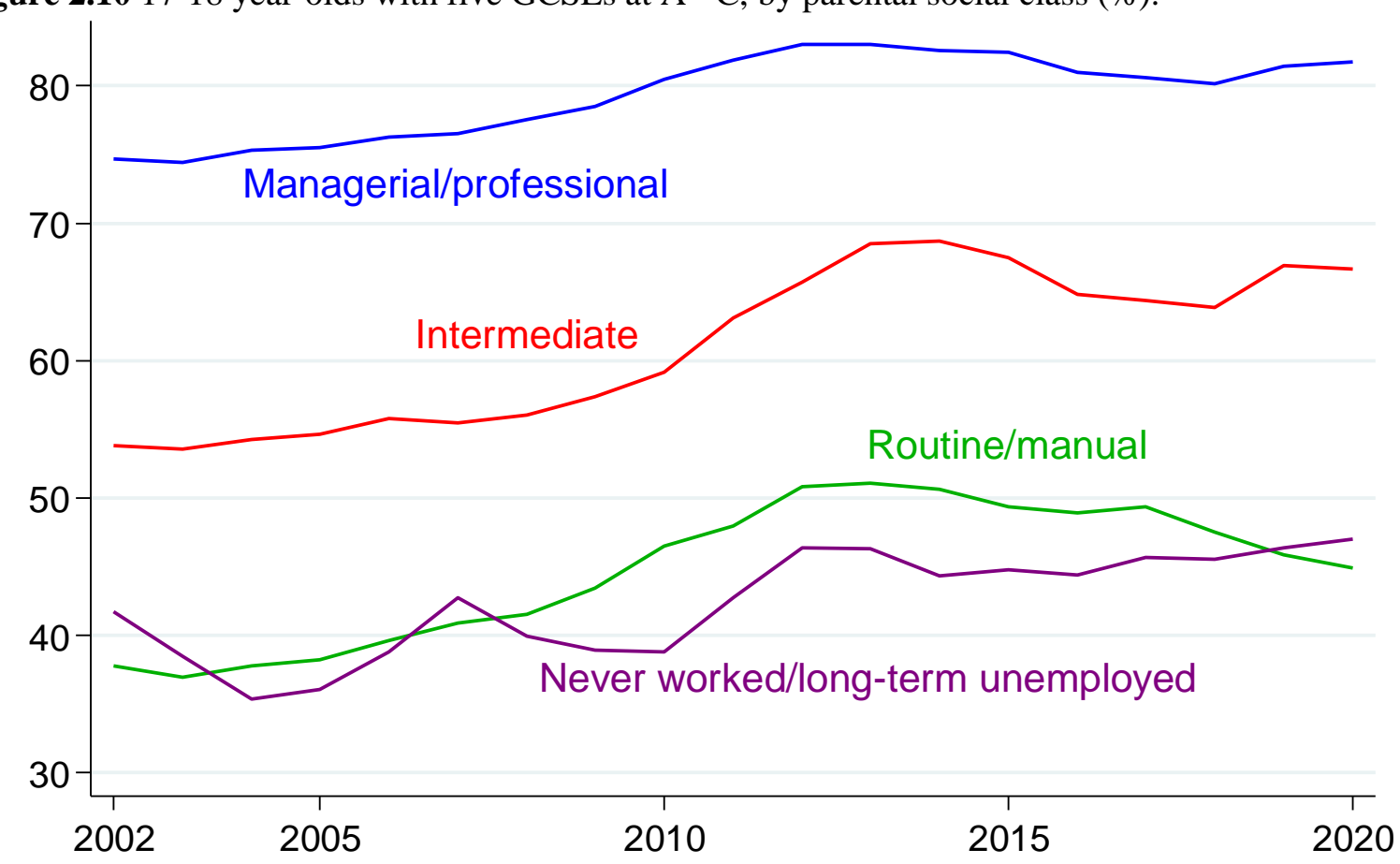

Source: Labour Force Survey (April-June). Includes Scottish equivalents. Includes vocational GCSEs from 2004 onwards. $A^{*}-C$ is equivalent to 4-9 under the new grading scheme. Three-year rolling average. Managerial/professional: NS-SEC analytic classes 1-2. Intermediate: 3-5. Routine/manual: 6-7. 
Figure 2.10 shows that since 2002 - as far back as this measure is available - the number achieving five 'good' GCSEs has risen for all groups, from those with parents in managerial or professional occupations to the small number without a parent in employment. But the gaps between these groups have nonetheless remained quite stable. More detailed research using rich datasets has found that sizeable and persistent class gaps in educational attainment are only in small part explained by differences in cognitive ability between students of different social backgrounds (Bukodi et al., 2014).

The effects of educational expansion on educational inequality have become a familiar story to sociologists (Boliver, 2017; Bukodi \& Goldthorpe, 2019; Lucas, 2001). On the face of it, inequality is reduced as the proportion of people achieving a given level approaches $100 \%$. There is no social inequality in the UK today in completing primary education, for instance (though there used to be). But the relatively advantaged deploy the same sorts of resources which had previously won them a greater share at the lower level of education to the next level up. Thus Blanden and Macmillan, studying UK cohorts born from 1958 to 2000, find that 'when our findings are adjusted for the growing supply of educated young people we find no narrowing of educational inequalities' (2016: 591).

The perhaps dismaying conclusion to which a great deal of evidence points is that education broadly acts as a channel through which advantage is passed from generation to generation, and that the most promising approach to tackling educational inequality involves equalising the home environment in which children's aptitudes and attitudes to education are first shaped (Bukodi \& Goldthorpe, 2019).

Figure 2.11 Child poverty rate (\%).

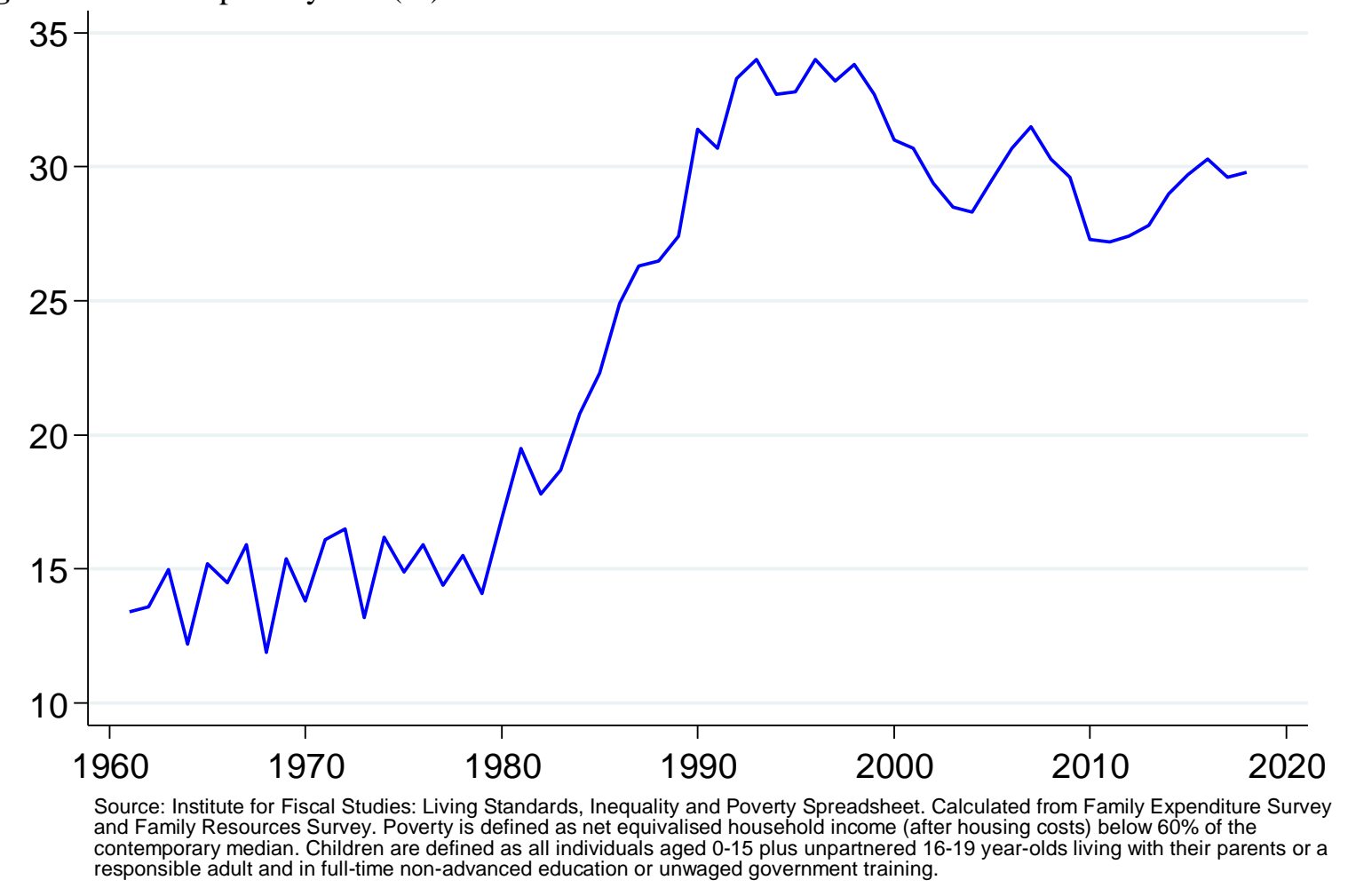

In this light, it is discouraging to note that the child poverty rate increased sharply from the end of the 1970s to the mid-1990s, and has remained high (Figure 2.11). Reforms that increased in-work benefits for mothers brought the rate down, but it has again been rising since $2010 .{ }^{15}$ The majority of children

\footnotetext{
${ }^{15}$ Cribb et al. (2017) goes into some detail on the causes of (trends in) child poverty. It increasingly owes to low earnings rather than worklessness.
} 
in poverty live in households where at least one adult is working (Cribb et al., 2017). An enormous research literature points to links between child poverty and a wide range of negative outcomes, including poor cognitive development and behavioural problems (Aber et al., 1997; Duncan et al., 1994; Kiernan \& Huerta, 2008). The stresses of poverty can limit parents' ability to provide a cognitively stimulating environment and contribute to harsh and unsupportive parenting styles which often go handin-hand with behavioural problems (Guo \& Harris, 2000). Perhaps counterintuitively, younger generations are more likely to grow up poor and experience these effects. This is likely to have stymied efforts towards equality of opportunity.

\section{Have standards improved?}

For all the resourcing and restructuring that has taken place in schools over time, has there been any discernible progress in educational standards? Anthony Heath's Social Progress in Britain neatly summarises the unfortunately sparse evidence on this question, concluding that it points to 'a story of stability or at most modest progress over time' (2018: 78). However this is a highly uncertain conclusion. ${ }^{16}$

We know regrettably little about whether standards have improved across generations because there are no measures which are plausibly consistent and span this length of time. To look back beyond the mid-90s, we are limited to the disparate sets of studies assembled by Rashid and Brooks (2010), which allow us to judge the trend in 15-year-olds' reading ability from 1960 to 1988 (no change), but then leave a gap until 1997 when a new data source appears - but which cannot be directly compared with the earlier sources. These authors also painstakingly document what is available to compare attainment over time in writing and numeracy, but no clear picture emerges.

The Trends in International Mathematics and Science Study (TIMSS) aims to measure students' abilities in a manner that is comparable both cross-nationally and over time, from 1995 onwards. Figure 2.12 plots the average scores of children from England and a handful of other countries for comparison. The general trend is stability over time in both science and maths among both year 5 (age 9-10) and year 9 (age 13-14) students. In the case of maths there is what appears to be a substantial improvement between 1995 and 2003 among 9-10 year-olds. However if this truly reflected a shift in standards we would expect that same jump to appear four years later in the age 13-14 data. Instead there is no change at all. So we should be cautious in interpreting any year-to-year jumps - such as the other noticeable change, a (statistically significant) decline in the science test scores of 13-14 year-olds in the latest data.

\footnotetext{
${ }^{16}$ Simply looking at grades (for instance of A-levels) over time is not the answer. Coe (2007) presents evidence of grade inflation over time and lists some of the other problems of interpretation.
} 
Figure 2.12 TIMSS test scores, 1995-2019.
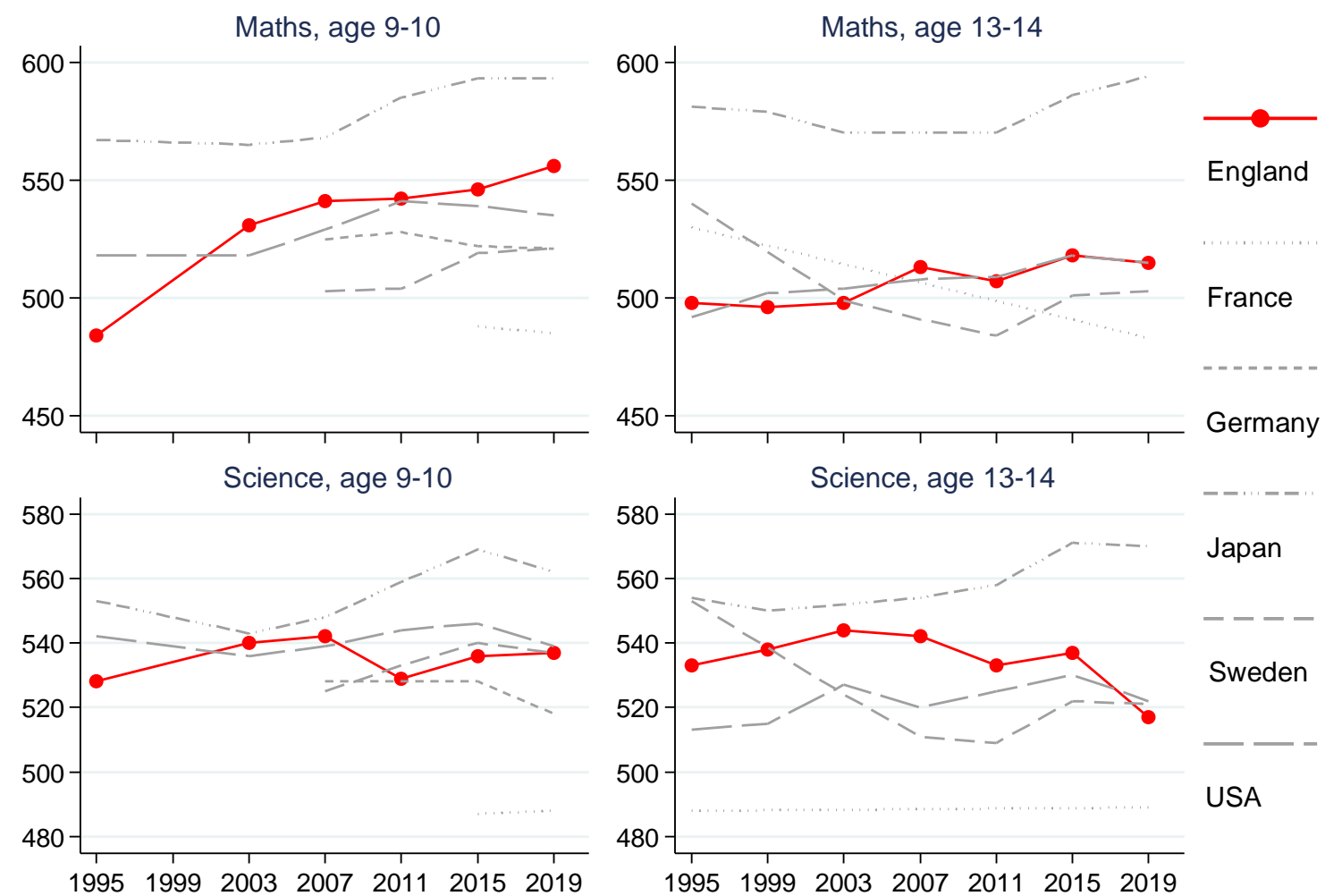

Source: International Association for the Evaluation of Educational Achievement (IEA), Trends in International Mathematics and Science Study (TIMSS). No data available for Germany in age 13-14 studies.

The OECD's Program for International Student Assessment (PISA) is similar and tests the abilities of 15-year-olds. This has run since 2000 (and incidentally covers the UK rather than just England). Unfortunately, the UK data from the 2000 and 2003 rounds are not of sufficient quality (Jerrim, 2013), so we only have comparable data from 2006 onwards. These data, shown in Figure 2.13, tell a reassuringly similar story to the TIMSS results covering the same period. They also suggest that the drastic fall across four years in the latest TIMSS science data is likely an aberration. However, the PISA data do indicate a statistically significant decline in science scores when comparing 2006 and 2018. Altogether this highlights a possible area of concern, though that might be tempered by looking at the wild fluctuations in some other countries' scores. It is more plausible that sampling error or one of the myriad other potential sources of incomparability caused the changes in Sweden's scores over time than the idea that the Swedish educational system went into a nosedive between 2006 and 2012, but then spectacularly turned things around.

For all the energy and contestation that goes into educational policy, it is unfortunate that more effort has not been made to try to rigorously evaluate whether changes have ultimately resulted in an objective improvement in students' reading, writing, maths, and so on. Like Heath, I find Coe's comment apt: 'Education has existed in a pre-scientific world, where good measurement of anything important is rare and evaluation is done badly or not at all' (2013: xvi).

In the next and final section of this chapter I review evidence on basic skills among adults - over the years, has the education system ultimately equipped people with the literacy, numeracy, and problem solving skills needed to fare well in the modern workplace? 
Figure 2.13 PISA test scores (age 15), 2006-2018.
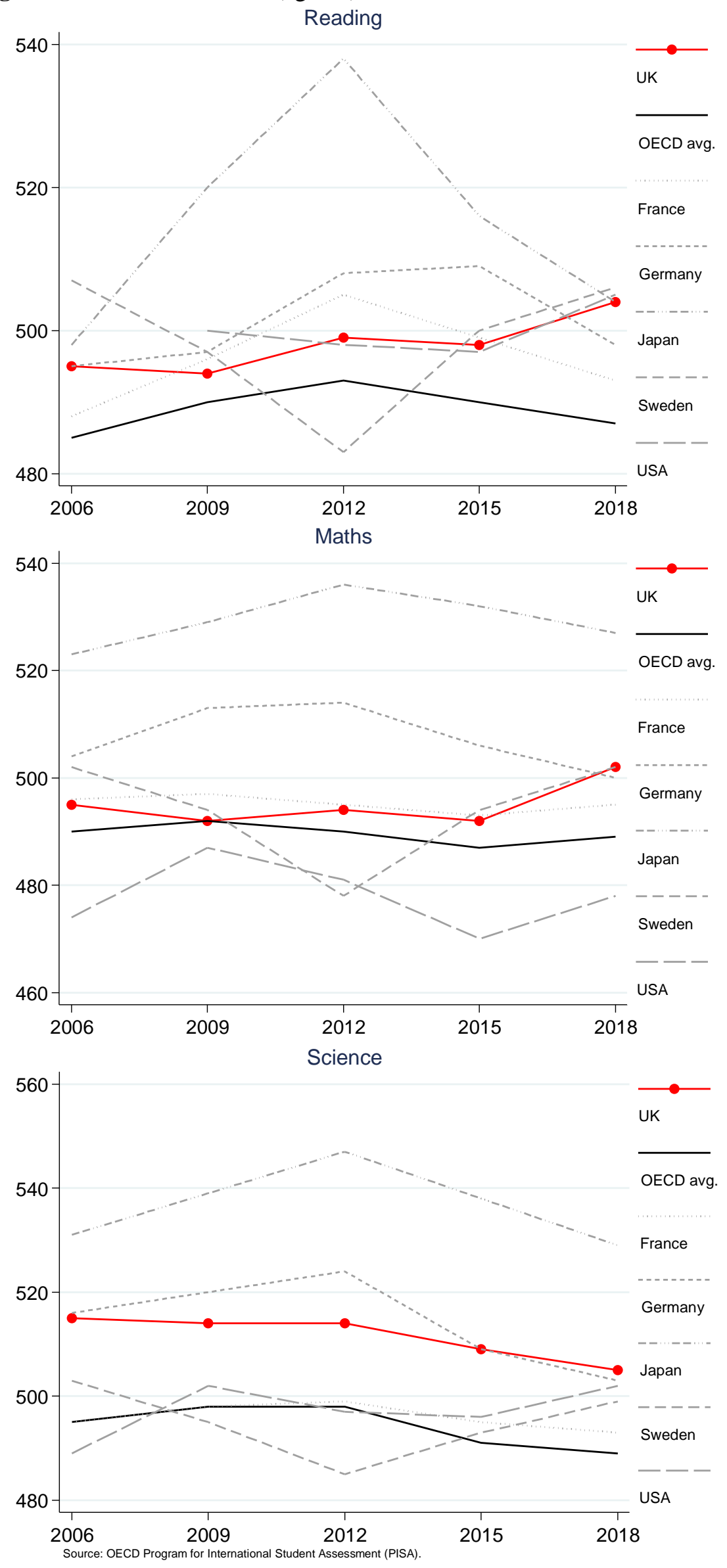


\section{Basic skills among working age adults}

As in the previous section, there is scant comparable over-time evidence on this topic. I therefore focus on the detailed albeit static picture revealed by the OECD's Survey of Adult Skills, in which England participated in 2011-12. ${ }^{17}$

Some secondary reports about this survey have been slightly misleading when comparing England to 'the OECD average', because this average changed as three sets of OECD member countries each took part in different years. ${ }^{18}$ With regard to the three 'headline' measures of basic skills, once data collection had finished, England stood at exactly the OECD average in numeracy, and comfortably above it in literacy and problem solving in technology-rich environments (OECD, 2019).

But this is hardly cause for celebration. It is debatable whether the OECD members which participated later in the survey programme and brought the OECD average down are appropriate comparators. In terms of numeracy for instance, England is clearly well behind most northern and western European nations (OECD, 2019: 51). But perhaps more importantly, the findings are striking when simply taken in absolute terms. OECD analysts (Kuczera et al., 2016: 9) write that:

There are an estimated 9 million working aged adults in England (more than a quarter of adults aged 16-65) with low literacy or numeracy skills or both ... These 9 million people struggle with basic quantitative reasoning or have difficulty with simple written information. They might, for example, struggle to estimate how much petrol is left in the petrol tank from a sight of the gauge, or not be able to fully understand instructions on a bottle of aspirin.

The survey also highlights some concerning ways in which the results for England are distinctive (Kuczera et al., 2016). Except for the US, all of the other 22 nations or regions surveyed around the same time as England had a substantially higher percentage of low-skilled adults in the 55-65 age group than in the 16-24 age group. Elsewhere, in other words, younger people had stronger basic skills than those approaching retirement. But in England, around 30\% in both of these age groups had low basic skills - comparatively normal for the older generation but lagging behind other countries as regards the younger generation. '[D]espite the rapid expansion of educational opportunities, and a relatively well qualified cohort of young adults [italics in original], the basic skills of this cohort have remained weak' (Kuczera et al., 2016: 10). ${ }^{19}$

Though this is a concerning picture, it is worth sounding a note of moderation. The results for England are all from a single assessment ten years ago in which 5,131 adults took part and four out of every ten invited to participate declined to do so (BIS, 2013). We also do not know whether steps already taken (such as mandating education or training to age 18) may have already begun to have a positive effect.

\footnotetext{
17 The Survey of Adult Skills is the main component of the OECD's Programme for the International Assessment of Adult Competencies (PIAAC). Different countries took part in the PIAAC first cycle in different years (201118), and data collection for a second cycle is planned for 2022-23.

${ }^{18}$ Regarding the mean numeracy score for instance, a Department for Business, Innovation and Skills report has England 'significantly below the OECD average' (BIS, 2013: 16) while later OECD reports have England 'not significantly different from the average' (2016: 22, 2019: 23).

${ }^{19}$ One of these OECD analysts, Simon Field, is quoted as claiming that 'Universities do nothing for basic skills ... No-one in the university world sees [developing students' skills] as their job, but on the other hand, they're quite happy to take anybody' (Lambert, 2019).
} 


\section{Employment and earnings}

The opportunities available to each new generation as it leaves education shift over time in the wake of broad societal changes. This chapter begins with an overview of the main trends that have shaped the UK economy and labour market over the past half-century, before making direct comparisons between the generations on measures such as their unemployment rate, earnings, and job security.

Let's first take a bird's eye view of the changing nature of the economy as a whole, and briefly look at some of the most important trends: deindustrialisation and the rise of services, women's participation in the labour market, occupational upgrading and polarisation, productivity and wage stagnation in the past decade, increases in regional and income inequality, the intensification of work, the changing youth labour market, and a possible oversupply of graduates.

\section{Deindustrialisation and the rise of services}

One way to think about what a country does at work is to split those activities into so-called primary, secondary, and tertiary production. Primary activities such as farming and mining get us the raw materials for everything else. Secondary activities involve converting them into more complex goods steel and rubber into cars, wood and fabric into furniture. Tertiary activities represent the vast array of services that we sell to one another.

Figure 3.1 shows how the share of employment has shifted between these sectors. The primary sector has long been only a minor part of the UK economy. Secondary sectors - mainly manufacturing but also construction and utilities - have declined steadily from their peak in the mid-1960s, and by 2016 accounted for only $15 \%$ of employment. The tertiary sector now dominates, accounting for over $80 \%$ of jobs. Broadly speaking, this trend and the patterns of occupational change discussed below owe to productivity gains arising from a combination of technological progress and globalisation (Goos \& Manning, 2007; Michaels et al., 2014), with educational expansion arguably playing a role too (Oesch \& Piccitto, 2019; Salvatori, 2018).

Figure 3.2 gives a little more detail about which types of activities have seen growth or decline over this period, showing the number of jobs in each Standard Industrial Classification industry since 1978. At the top we see steady growth in human health and social work; professional, scientific, and technical activities; and administrative and support services. At the other end, the figure makes clear just how pronounced the fall in manufacturing employment has been, from over 6.7 million jobs in 1978 to 2.7 million at the end of 2019. At the same time, it is easy to forget that this industry remains one of the UK's largest in terms of jobs, comparable to education or construction.

The categories used in Figure 3.2 are quite broad. Table 3.1 lists some illustrative activities for the five industries which have added the most jobs over this period. For instance, a lot more people are employed in health and social care, a sector spanning hospitals, nursing homes, social work, and child day-care. The question this might raise is whether that means a lot more people doing high-skilled jobs like practising medicine, or a lot more low-paid, 'low-skill' care workers. I will turn to this soon. 
Figure 3.1 The changing distribution of employment across sectors (\% of jobs).

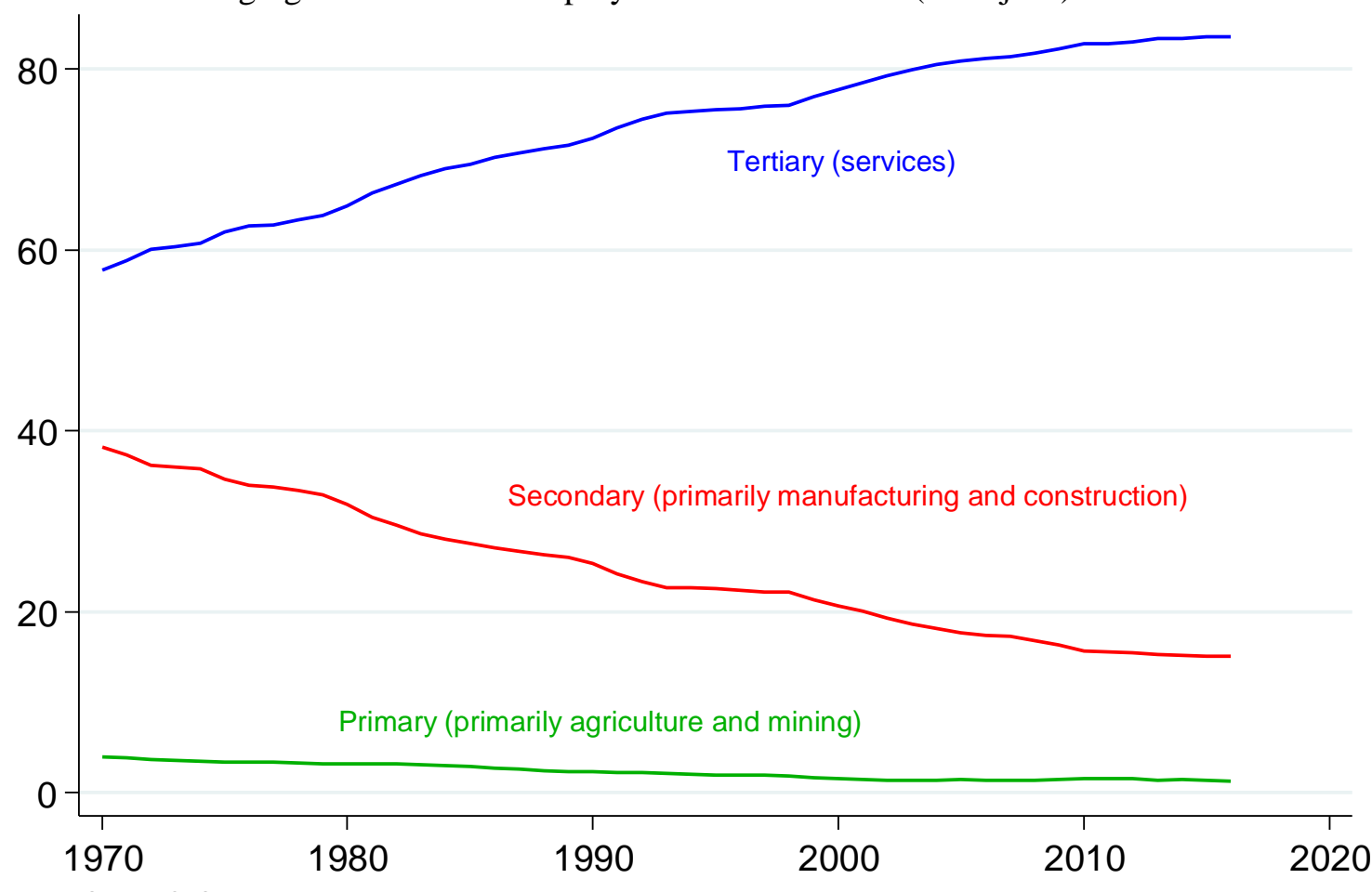

Source: ONS, Bank of England.

Figure 3.2 Number of jobs, by industry (millions).
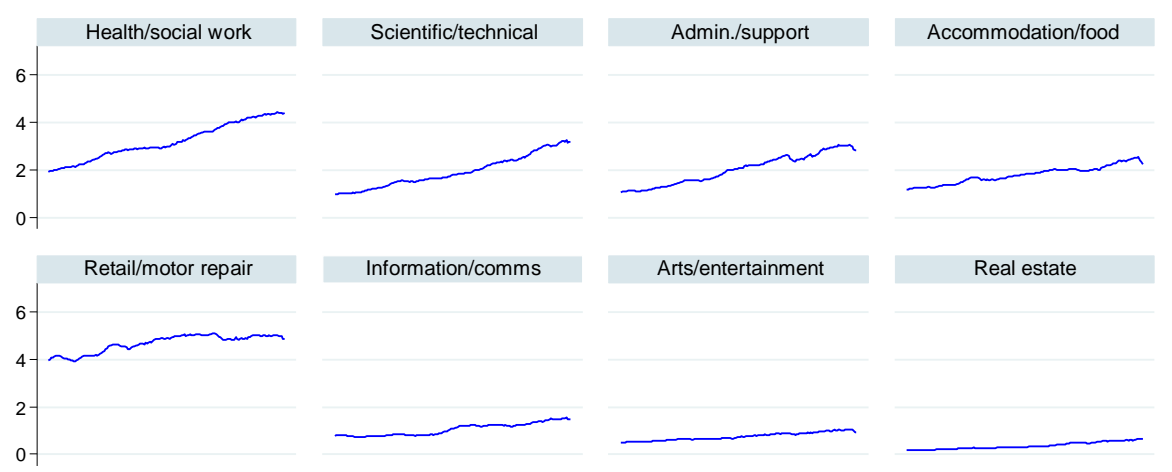

Arts/entertainment

Real estate
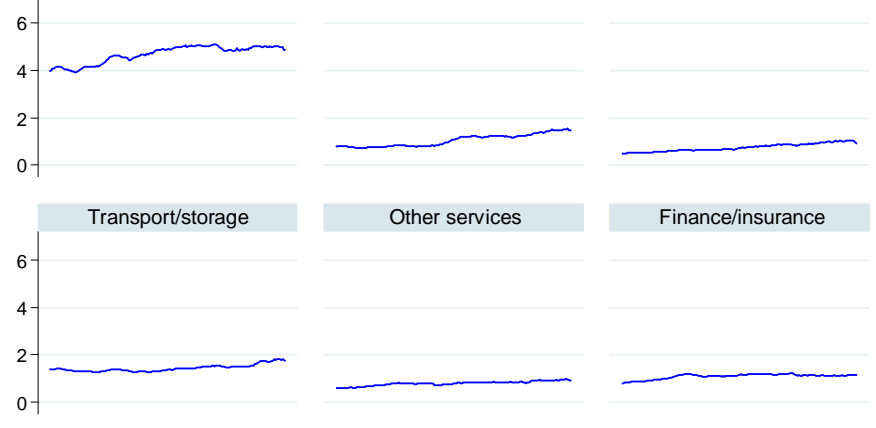

Other services
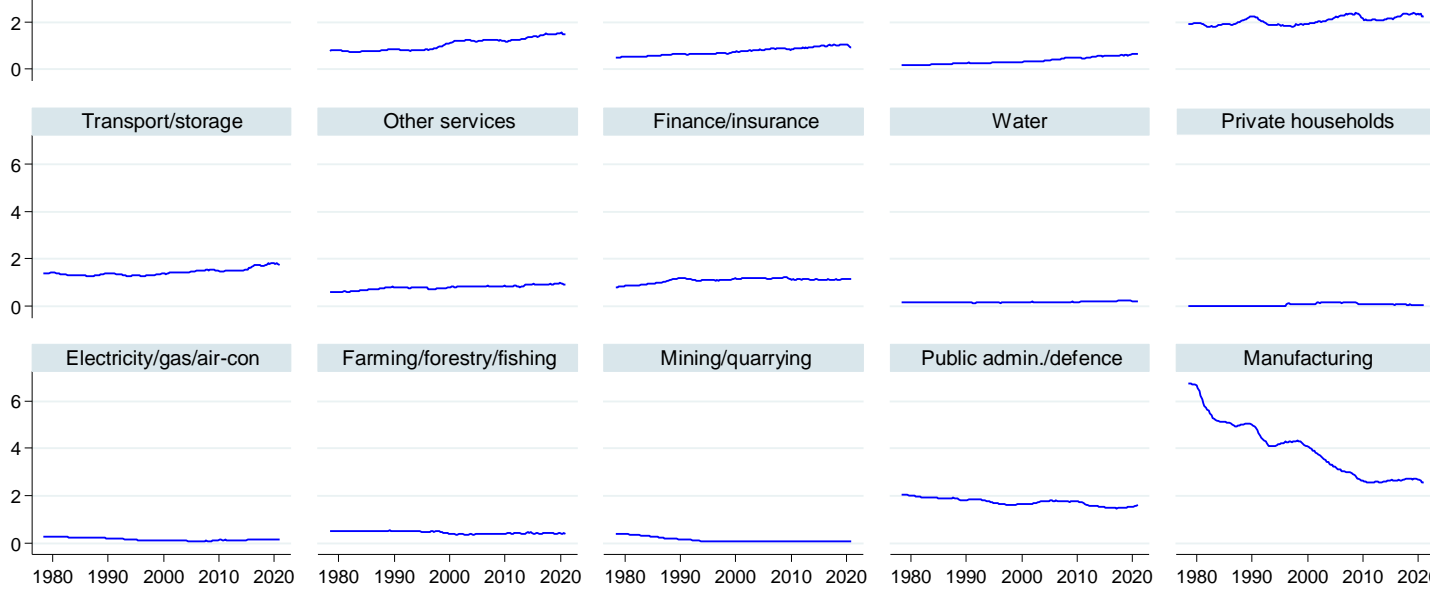

Farming/forestry/fishing
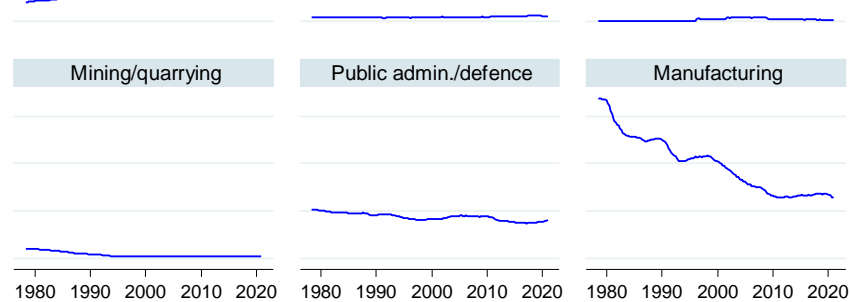
Source: ONS. Presented in descending order of absolute change between 1978 and 2019. Categorised according to UK Standard Industrial Classification of Economic Activities 2007 (SIC 2007). 
Table 3.1 Industries which added the most jobs between 1978 and 2019, with examples of activities within each industry.

\begin{tabular}{|l|l|l|}
\hline SIC 2007 Industry & $\begin{array}{l}\text { Jun. 1978 - Dec. 2019 } \\
\text { change }\end{array}$ & Examples \\
\hline $\begin{array}{l}\text { Human health and } \\
\text { social work activities }\end{array}$ & $+2,490,000$ & $\begin{array}{l}\text { Hospital services, medical and dental practice, } \\
\text { residential care, social work, child day-care }\end{array}$ \\
$\begin{array}{l}\text { Professional, } \\
\text { scientific, and } \\
\text { technical activities }\end{array}$ & $+2,221,000$ & $\begin{array}{l}\text { Legal services, accounting, activities of head } \\
\text { offices, management consultancy, architectural } \\
\text { and engineering, scientific research, advertising } \\
\text { and market research, veterinary services }\end{array}$ \\
\hline $\begin{array}{l}\text { Administrative and } \\
\text { support services } \\
\text { activities }\end{array}$ & $+1,955,000$ & $\begin{array}{l}\text { Rental and leasing, employment services, travel } \\
\text { agency, security and investigation, facilities } \\
\text { support, cleaning, office administration, } \\
\text { business support, call centres }\end{array}$ \\
\hline $\begin{array}{l}\text { Accommodation and } \\
\text { food service activities }\end{array}$ & $+1,357,000$ & $\begin{array}{l}\text { Hotels, camping grounds, restaurants, catering, } \\
\text { mobile food services, pubs, bars }\end{array}$ \\
\hline Education & $+1,234,000$ & $\begin{array}{l}\text { Education from pre-primary to further and } \\
\text { higher, sports and recreational education, } \\
\text { driving schools, educational consulting }\end{array}$ \\
\hline
\end{tabular}

\section{Women's participation in the labour market}

It may seem obvious, but it is one of the most striking changes to have taken place across the past halfcentury: far more women are in employment. Among other changes, this reflects the decline of the single-earner family. The norm is now for mothers to return to the workplace after a period of maternity leave rather than leave the workforce for good.

Figure 3.3 Labour force participation rate, by sex (\%).

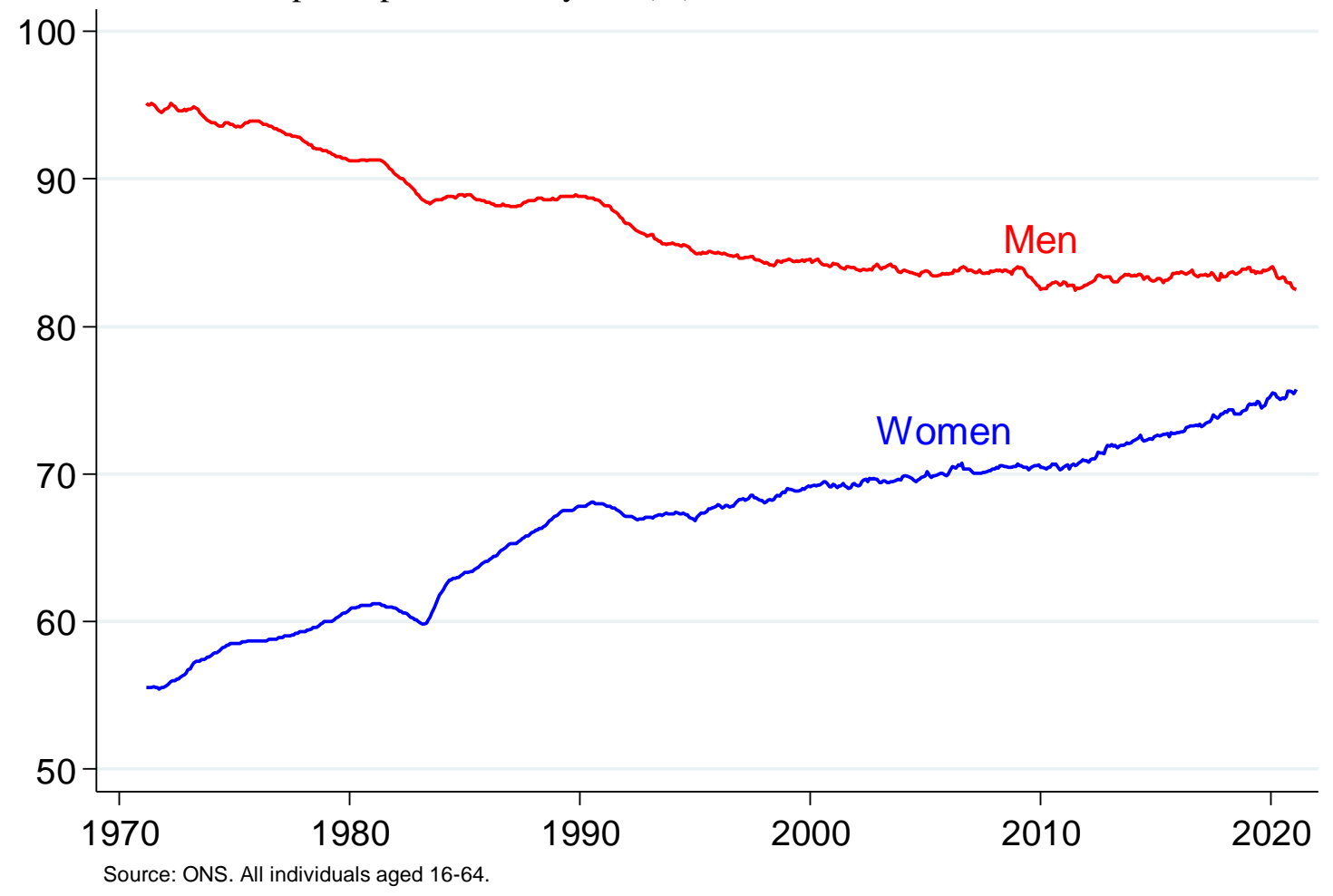




\section{Occupational upgrading and polarisation}

We have just seen that employment has shifted away from industry and towards services. But what does that really mean for the sort of work people are doing? Does it mean more 'good' jobs - or just a shift from the factory floor to low-paid, monotonous work in call centres and warehouses?

The big picture answer to this question, over the period we are considering, is simply that there are many more 'good' jobs in this country than there used to be. What do I mean by 'good'? One very useful way to categorise jobs is according to social class. Here I am referring to the National Statistics Socio-Economic Classification (NS-SEC). The term 'social class' may carry a lot of baggage and seem somewhat subjective, but this particular measure is very much an objective one, subject to repeated validation studies and grounded in thorough and widely-accepted research. ${ }^{20}$ Table 3.2 shows the sevencategory version of the NS-SEC, with some examples of occupations from each category.

Table 3.2 NS-SEC seven-class version and representative occupations.

\begin{tabular}{|l|l|l|}
\hline Class & Description & Representative occupations \\
\hline 1 & $\begin{array}{l}\text { Higher managers and } \\
\text { professionals }\end{array}$ & $\begin{array}{l}\text { General managers in large companies and organisations, higher- } \\
\text { grade civil servants and local government officials, architects, } \\
\text { lawyers, medical practitioners, professional engineers, scientists, } \\
\text { university teachers }\end{array}$ \\
\hline 2 & $\begin{array}{l}\text { Lower managers and } \\
\text { professionals }\end{array}$ & $\begin{array}{l}\text { General managers in small companies and organisations, site } \\
\text { managers, office managers, workshop managers, lower-grade } \\
\text { civil servants and local government officers, librarians, nurses, } \\
\text { physiotherapists, school teachers, social workers, surveyors }\end{array}$ \\
\hline 3 & $\begin{array}{l}\text { Ancillary } \\
\text { professional and } \\
\text { administrative } \\
\text { Small employers and } \\
\text { own account workers }\end{array}$ & $\begin{array}{l}\text { Computer maintenance staff, draughtspersons, library assistants, } \\
\text { nursery nurses, paramedical staff, cashiers, clerical workers, data } \\
\text { processing operators, personal assistants, secretaries }\end{array}$ \\
\hline 5 & $\begin{array}{l}\text { Gowage proprietors, builders, café proprietors, craftsmen, market } \\
\text { traders, publicans, shopkeepers }\end{array}$ \\
\hline 5 & and technical \\
occupations & $\begin{array}{l}\text { Semi-routine } \\
\text { occupations }\end{array}$ & $\begin{array}{l}\text { Foremen, site and works supervisors, auto engineers, heating } \\
\text { engineers, instrument technicians, laboratory technicians, } \\
\text { printers, tool- and pattern-makers, TV and video engineers }\end{array}$ \\
\hline 6 & $\begin{array}{l}\text { Care assistants, caretakers and housekeepers, chefs and cooks, } \\
\text { chemical process workers, crane drivers, factory machinists, } \\
\text { fitters, postal workers, receptionists, sales assistants, store } \\
\text { controllers and despatchers, traffic wardens }\end{array}$ \\
\hline 7 & $\begin{array}{l}\text { Routine occupations } \\
\text { Bus and van drivers, construction site and other labourers, } \\
\text { craftsmen's mates, food process workers, counter and bar staff, } \\
\text { house and office cleaners, kitchen assistants, packers and fillers, } \\
\text { porters and attendants, refuse collectors, warehouse workers }\end{array}$ \\
\hline 9 & &
\end{tabular}

Source: Bukodi and Goldthorpe (2019).

NS-SEC classes 1 and 2 tend to be characterised by higher pay, more autonomy, greater job security, and good prospects for advancement along a well-defined 'career ladder' (including pay rises along the way). Classes 6 and 7, by contrast, represent more-or-less routine, standardised work; such jobs are less well-paid and more likely to involve unpredictable working patterns or job endings. There is less scope for advancement. From a cold economic standpoint, workers in these jobs are more-or-less interchangeable and don't need a lot of training to do the work. 3, 4, and 5 are each different but can be thought of as falling in the middle in most respects.

${ }^{20}$ For more information, see Rose et al. (2005) or search 'ONS NS-SEC'. 
How has the distribution of workers between these classes changed over the past half-century? As Figure 3.4 shows, what used to look in 1971 like a pyramid now looks more like a square: many more of us are in these more desirable, better-paying jobs. The proportions of both working men and women in managerial and professional work has roughly doubled, while the proportions doing semi-routine or routine work has roughly halved. This long-term trend is the 'occupational upgrading' of the title of this subsection.

Figure 3.4 NS-SEC class distributions of economically active men and women, 1971 and $2021(\%)$.

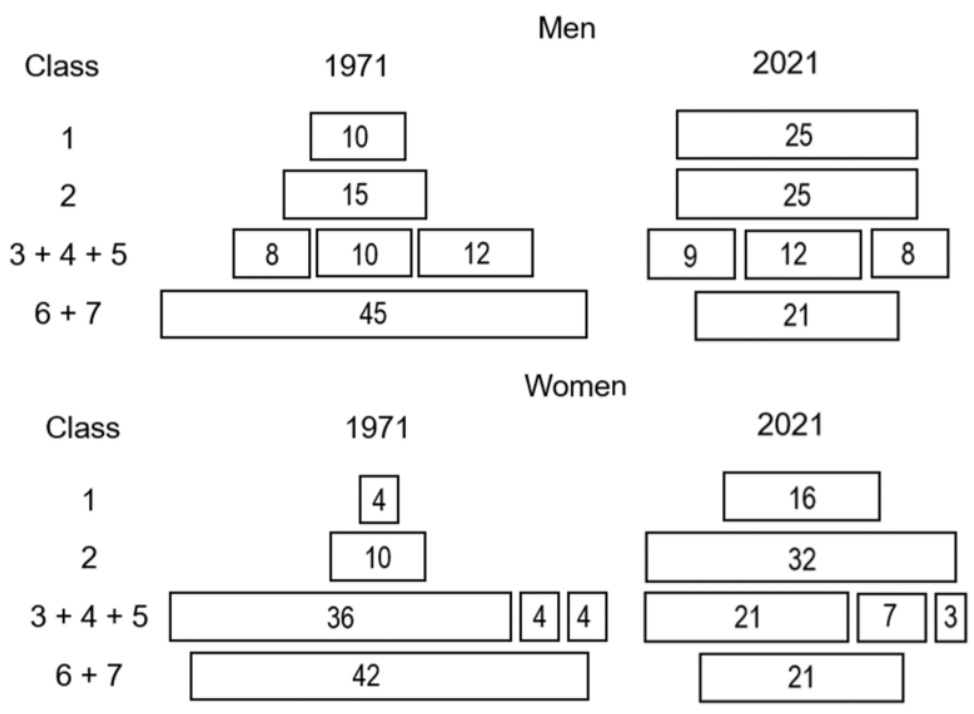

Source: Bukodi and Goldthorpe (2019) for 1971. Quarterly Labour Force Survey May-July 2021 for 2021.

Table 3.3 gives us a sense of what sorts of specific occupations have been growing and declining the most, underneath this 'big picture' of upgrading. Well-paid jobs in business and management have grown, but so too has care work. Decline has been concentrated in industrial jobs, and in support roles whose functions are now largely carried out by technology.

Table 3.3 Occupations with the greatest absolute job growth and decline, 1992-2015.

\begin{tabular}{|l|r|r|}
\hline & \% in $\mathbf{1 9 9 2}$ & \% in $\mathbf{2 0 1 5}$ \\
\hline Greatest growth & & \\
\hline Business professionals & 1.1 & 6.4 \\
\hline Personal care and related workers & 2.9 & 7.3 \\
\hline Corporate managers (private sector) & 8.4 & 11.6 \\
\hline Finance and administrative associate professionals & 3.0 & 6.1 \\
\hline Computing and hard science professionals & 1.5 & 3.1 \\
\hline & & \\
\hline Greatest decline & & \\
\hline Precision and printing craft workers & 3.1 & 1.2 \\
\hline Machine operators and assemblers & 4.0 & 1.6 \\
\hline Library, mail, and office clerks & 8.8 & 4.9 \\
\hline Salespersons & 5.3 & 0.9 \\
\hline Secretaries and transport clerks & 5.4 & 0.7 \\
\hline
\end{tabular}

Source: Oesch and Piccitto (2019).

What about the 'polarisation' also mentioned in the title of this subsection? This refers to another pattern of occupational change over recent decades, whereby job growth is occurring not just among the best 
jobs but also the worst, while the share employed in middling jobs is declining. This is also sometimes referred to as a 'hollowing out' of the labour market, or an 'hourglass' pattern in place of the pyramids and squares of Figure 3.4. There is a hint of it in the appearance of care work in the table above, among the occupations that have seen the greatest growth.

Figure 3.5 shows the extent of polarisation between 1992 and 2015 based on occupations' pay (Oesch $\&$ Piccitto, 2020). ${ }^{21}$ It begins by splitting occupations into five equally sized groups (quintiles) based on their average pay in 1992, and shows how the share of workers in each of those occupation groups had changed by 2015. Polarisation and a growth of low-pay jobs has indeed occurred to an extent (and more for men than women (Cristini et al., 2018)), but upgrading remains the dominant overall pattern (Oesch \& Piccitto, 2019; Salvatori, 2018). It is concerning, however, that wages have grown little among these initially low-paid occupations while the initially high-paying occupations have seen stronger wage growth (McIntosh, 2013).

Figure 3.5 Employment share in 2015 by 1992 median earnings quintiles (\%).

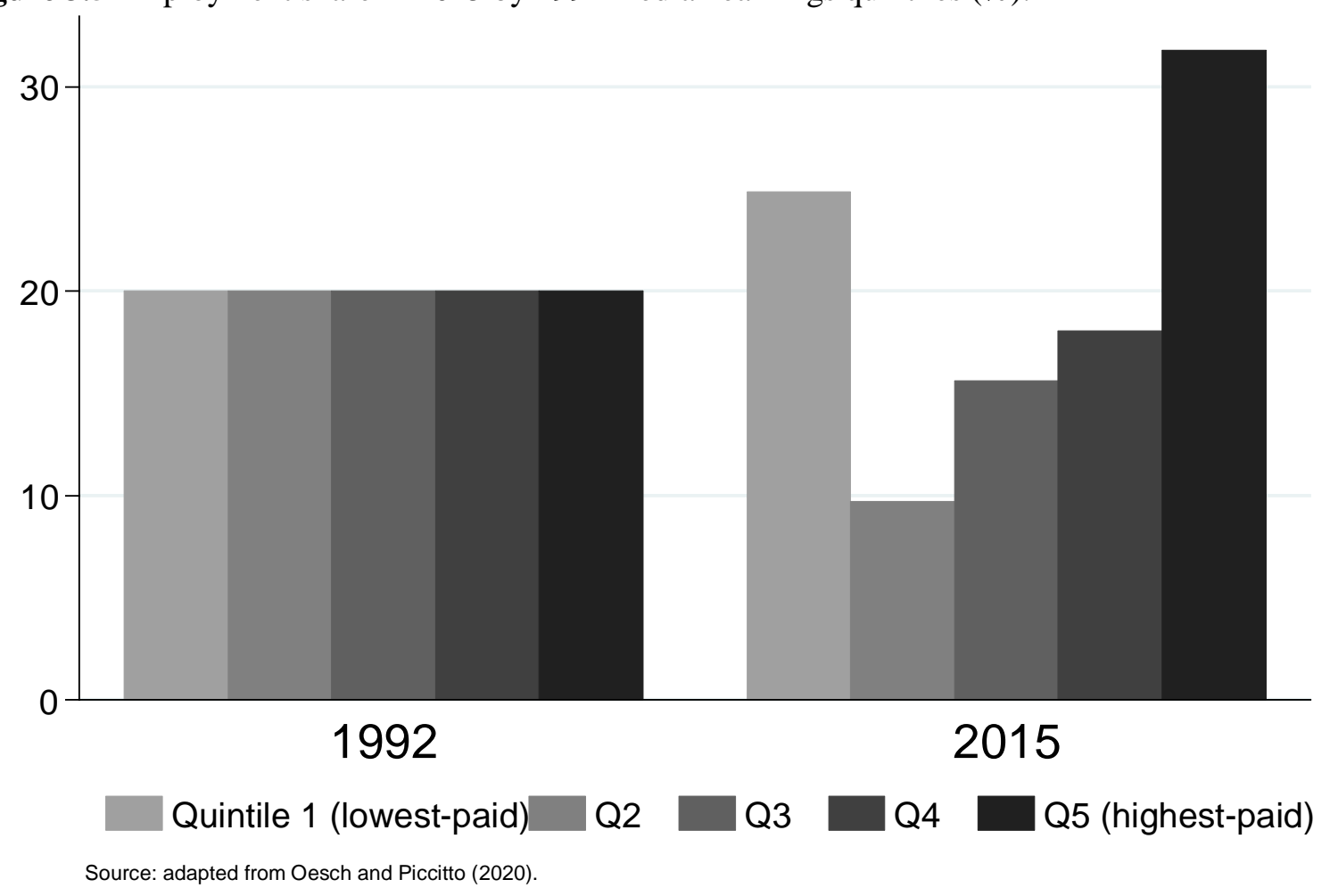

This polarisation pattern is only evident if we rank occupations in terms of their wage. If they are instead ranked on their average educational level, prestige, or job satisfaction, the pattern is very clearly one of occupational upgrading (Oesch \& Piccitto, 2019). So the growing low-pay occupations at least aren't bad jobs in every sense. And as the example of care work emphasises, low-paid work need not imply work of low value in the broader sense. Nor need any given occupation necessarily be low-paid in absolute terms - this is the outcome of our collective decision-making mediated through our institutions, and can be changed.

One important step in that direction - increasing the absolute pay of the relatively low-paid - has been the introduction in 2016 of the National Living Wage (Cooper et al., 2019). Recent ONS figures indicate

\footnotetext{
${ }^{21}$ Evidence from a longer timespan suggests that growth in the lowest-paying jobs began in the 1990s (Cristini et al., 2018).
} 
that the percentage of low-paid jobs (when defined as those paying two-thirds or less of median hourly earnings) has fallen to its lowest point (15.1\%) since 1997 when data was first collected and the figure stood at $21.8 \%$ (ONS, 2020).

This section has focused on overall occupational change. Later we will look at what this all means for different generations.

\section{Productivity and wage stagnation}

Productivity refers to how efficiently goods and services are being produced; it is often measured as the output per unit of input. As already mentioned, the transition to a services-based economy went handin-hand with steady productivity growth. However this growth ended quite abruptly with the financial crisis of 2007-2009, which in turn has been attributed to financialisation, the deregulated growth of the financial sector to the point of destabilising excess (Kay, 2016). As shown in Figure 3.6, productivity has essentially stood still for the past decade. This stagnation is so fundamental that the Royal Statistical Society judged its UK Statistic of the Decade for the 2010 s to be ' $0.3 \%$ : the estimated average annual increase in UK productivity in the decade or so since the financial crisis' (Royal Statistical Society, 2019). This contrasts with around $2 \%$ per year from 1997-2007 and marks the past decade as the worst for productivity growth since the early $1800 \mathrm{~s}$. Had the pre-crisis trend continued, it is estimated that productivity would be around a fifth higher, bringing a substantially higher standard of living. This trend is mirrored in real-terms average wages which, at the onset of the pandemic, had still not quite recovered to pre-crisis levels (see Figure 3.7).

While other advanced economies also experienced a productivity slowdown following the financial crisis, the UK's has been among the most dramatic and has followed decades of lower productivity growth than other G7 nations. An international comparison of labour productivity (Tenreyro, 2018: 5) is quite striking:

If British workers were able to catch-up to the G7 average, what currently takes us five days' work to produce could be done in little over four. If we were able to catch up to Germany, we might all be able to go home from work on Thursday afternoon each week without any fall in GDP.

The causes of this stagnation are unclear and much-debated - hence frequent references to the UK's 'productivity puzzle'. Ilzetzki (2020) presents a useful summary of the debate based on a survey of leading economists. Among the probable contributing factors are: low demand, driven by austerity and Brexit uncertainty; employees' skills that are both poor and often mismatched to their field of work; and sluggish investment across research and development, job-relevant training, and productive sectors more generally. ${ }^{22}$

\footnotetext{
${ }^{22}$ This is not an exhaustive list of the proposed causes. Among others, there is also a suggestion that the apparent stagnation may have more to do with the difficulties of measuring productivity - or the effect of dividing total economic output by an apparently larger-than-ever number of workers which actually includes many who are only quite loosely involved in work. In other words, 'output per worker' as a measure of productivity will look low if the sort of people who in the past didn't work at all (e.g. people of retirement age) increasingly do some work, such as casual self-employment or an occasional shift in a job they recently retired from. On the other hand, 'output per hour' very closely follows 'output per worker' in Figure 3.6, so this may not be a major issue.
} 
Figure 3.6 UK productivity indices $(2018=100)$.

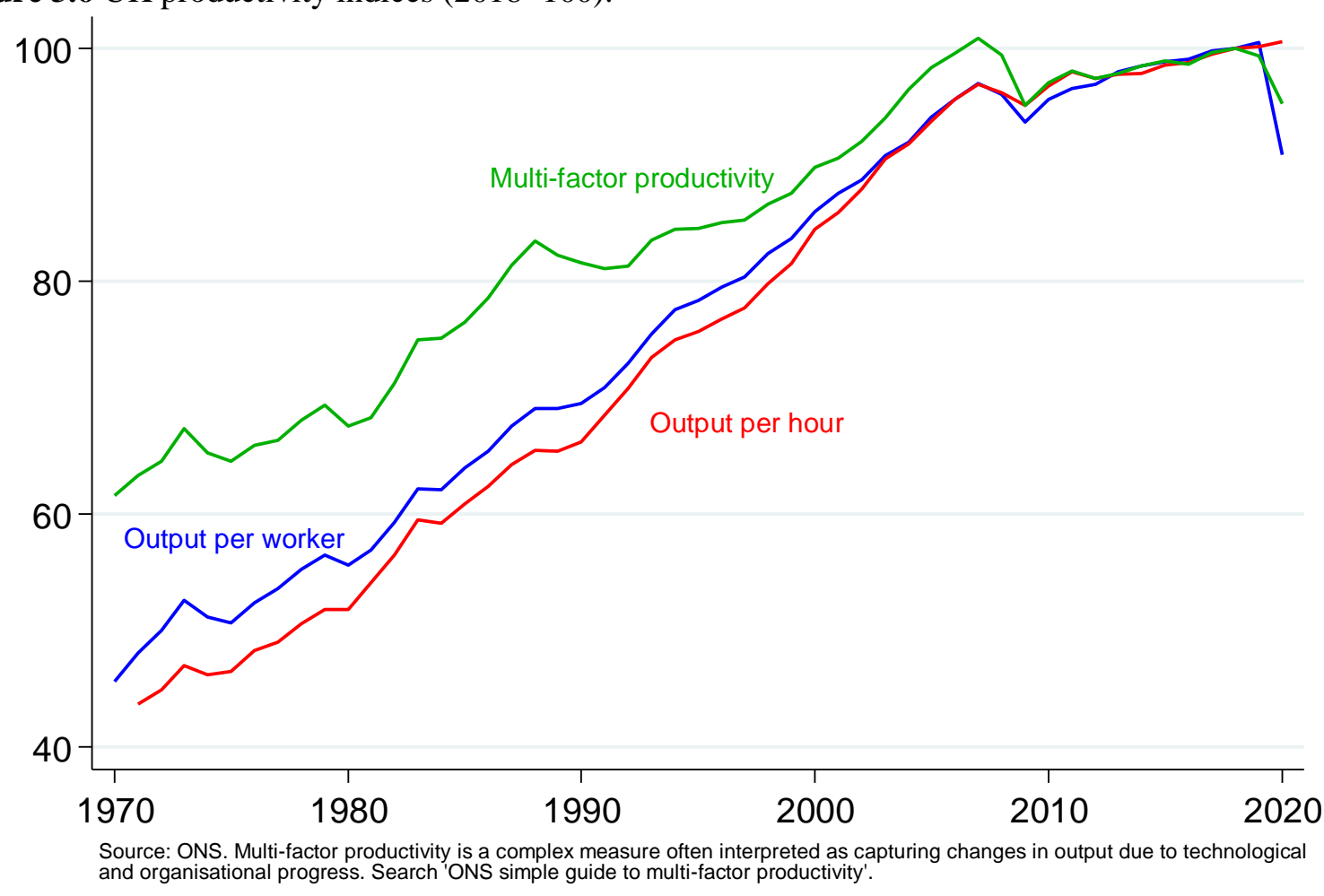

Figure 3.7 Real average weekly wages ( $£, 2015$ prices).

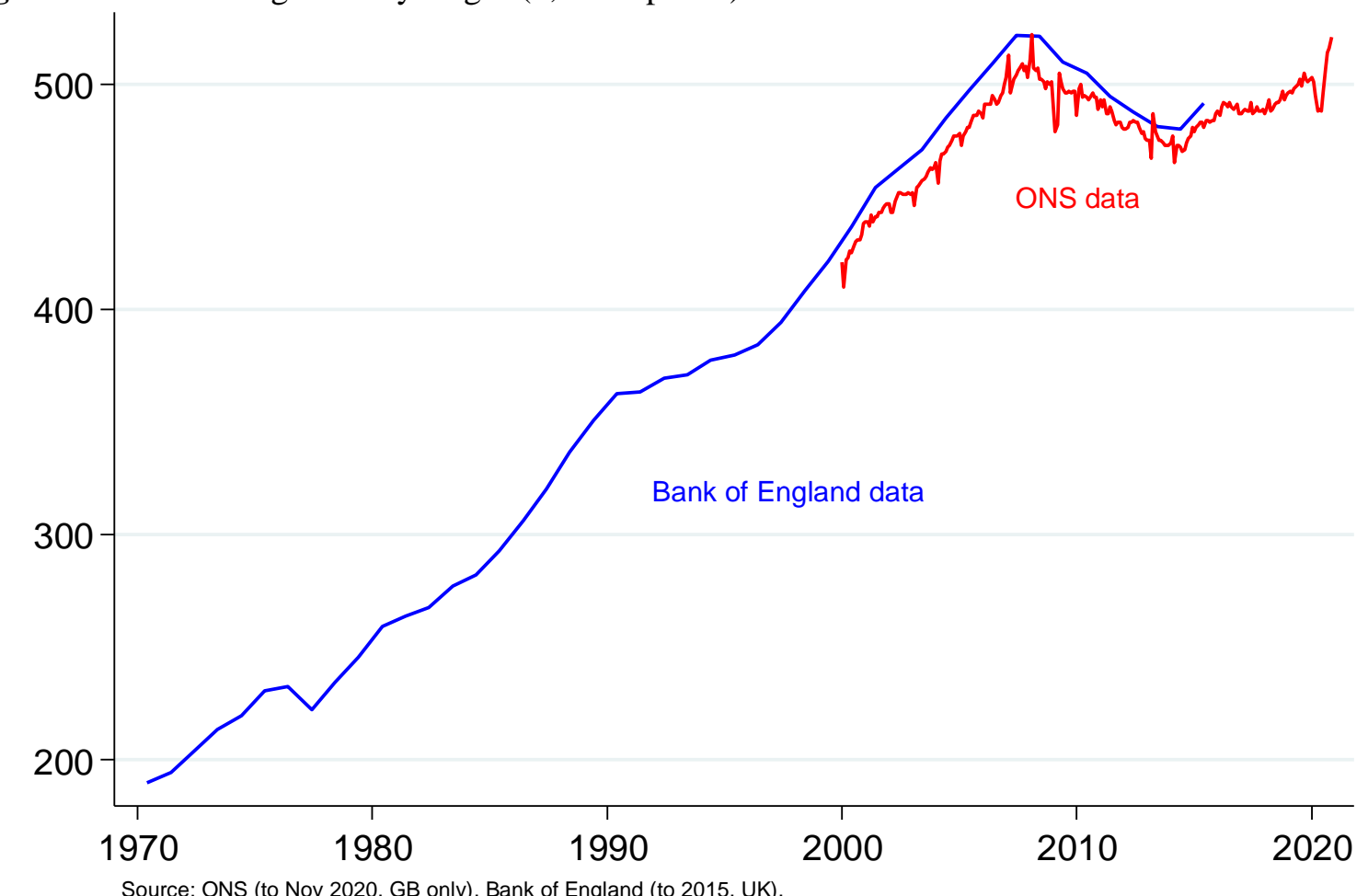




\section{Regional and income inequality}

There have been important changes in the distribution of both productivity and incomes in recent decades.

Productivity - closely linked to earnings - has become increasingly concentrated in London following the decline of manufacturing, which had been spread across the UK's regions. Figure 3.8 shows each region's productivity relative to the country as a whole. ${ }^{23}$ London has long stood apart on this measure, but only recently to such a great extent. From 1970 when manufacturing remained a large sector until even the early 1990s productivity was spread relatively evenly around the country. From then until the mid-2000s, however, a large gap opened up between London (and to a lesser extent the rest of the South East) and the other regions and nations. Wales and the North East have seen particularly sharp declines on these measures, and the former currently stands as the least economically productive part of the UK.

Income inequality grew substantially across the 1980 s and has remained stable since (Figure 3.9). The highest-income fifth of individuals have $42.4 \%$ of all disposable household income, up from $35.2 \%$ in 1977; the lowest-income fifth saw their share decrease from $9.7 \%$ to $6.8 \%$ over the same period.

Figure 3.8 Regional productivity relative to the GB/UK average (100). ${ }^{24}$

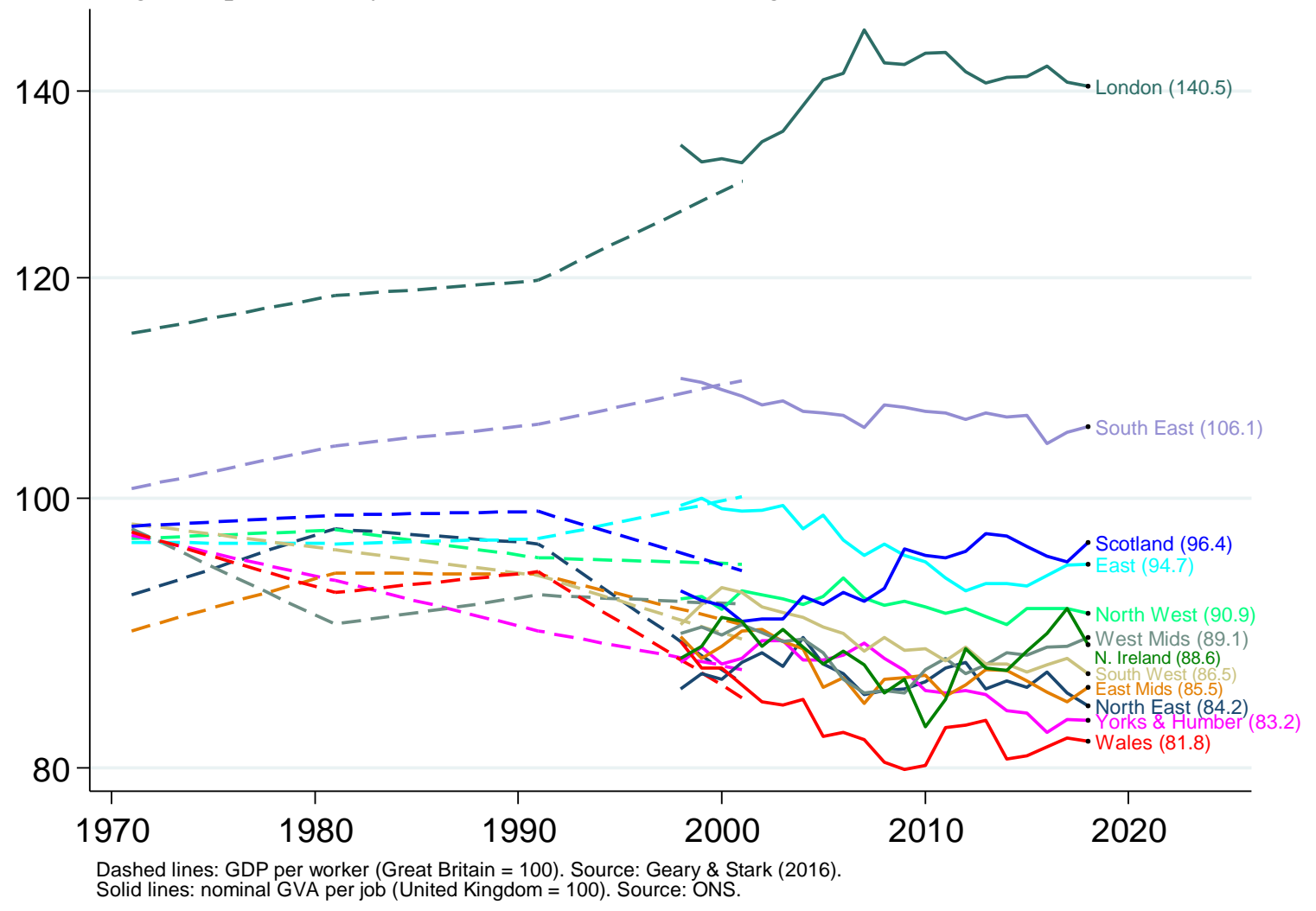

\footnotetext{
${ }^{23}$ This figure combines Geary and Stark's (2016) estimates spanning the twentieth century with more recent data from the ONS.

${ }^{24}$ The report by Zymek and Jones (2020) for the Industrial Strategy Council led me to Geary and Stark's work.
} 
Figure 3.9 Share of total disposable household income by quintile group of individuals (\%).

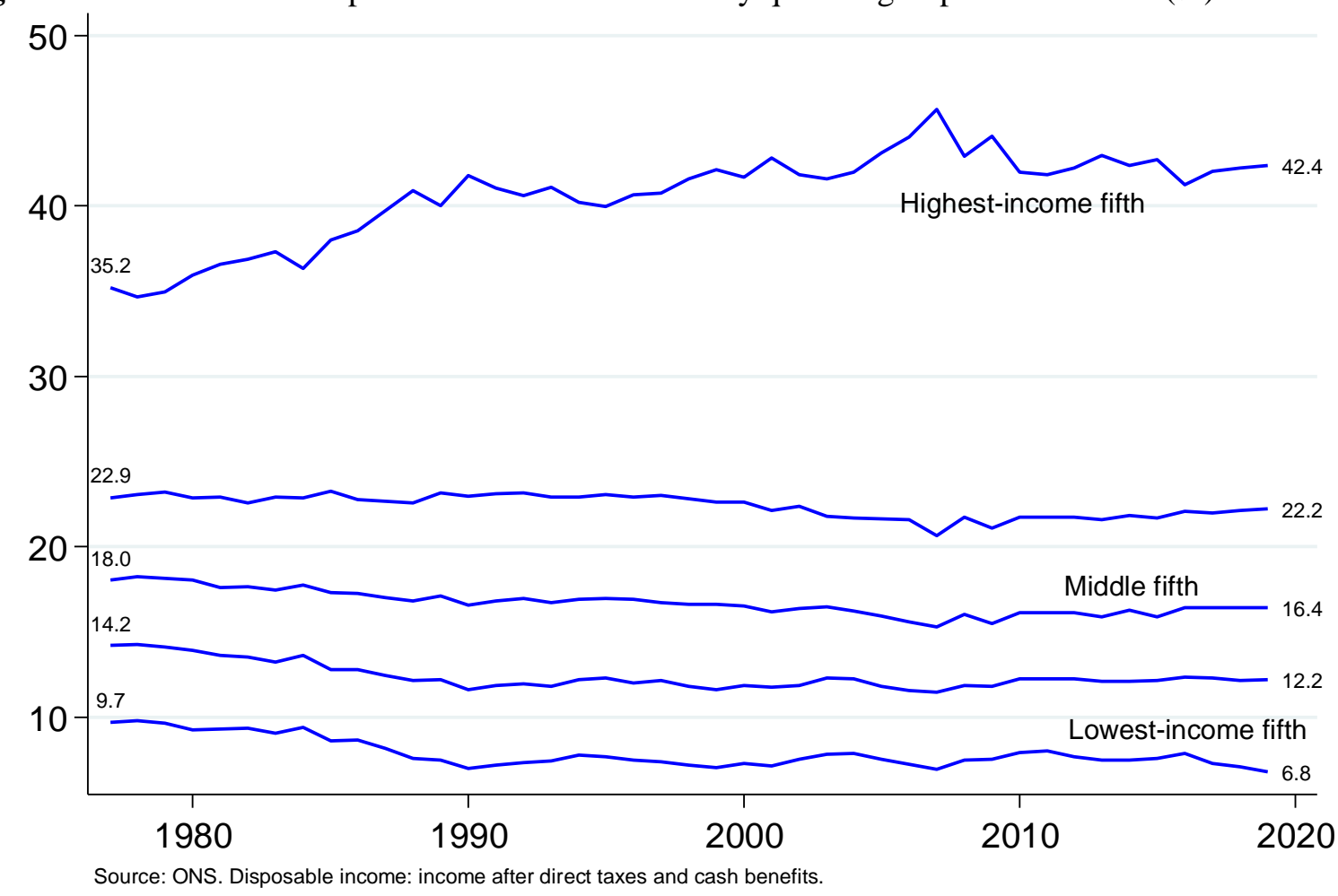

\section{Work intensification}

For the past three decades, the Skills and Employment Survey has collected extensive data from workers about their everyday workplace experience. Interviews span a range of topics including productivity, skills, fairness, intensity, participation, and insecurity.

What does it tell us about how the nature of work itself has changed? We saw in the chapter on education that work has become more intense for teachers. As Figure 3.10 shows, this seems to be part of a wider trend (Green et al., 2018). (Note that although there is a similar pattern of increase, the actual numbers are far higher among teachers than workers overall (Figure 2.7).) The latest data, from 2017, suggests that British workers are working harder and faster than at any time since 1992. A related trend is a pronounced decline in levels of task discretion, or autonomy - the degree of control an individual has over how to do their job (Gallie et al., 2018).

The survey also asks workers whether they feel their job is at risk. In 2017, perceived risk of job loss was at its lowest since the surveys began in 1986. But job insecurity may be taking on new forms: a new question in the 2017 survey identified 7\% of the workforce as 'very anxious' that their hours of work might change unexpectedly (Felstead et al., 2018). 
Figure 3.10 Workers reporting high work intensity, various measures (\%).

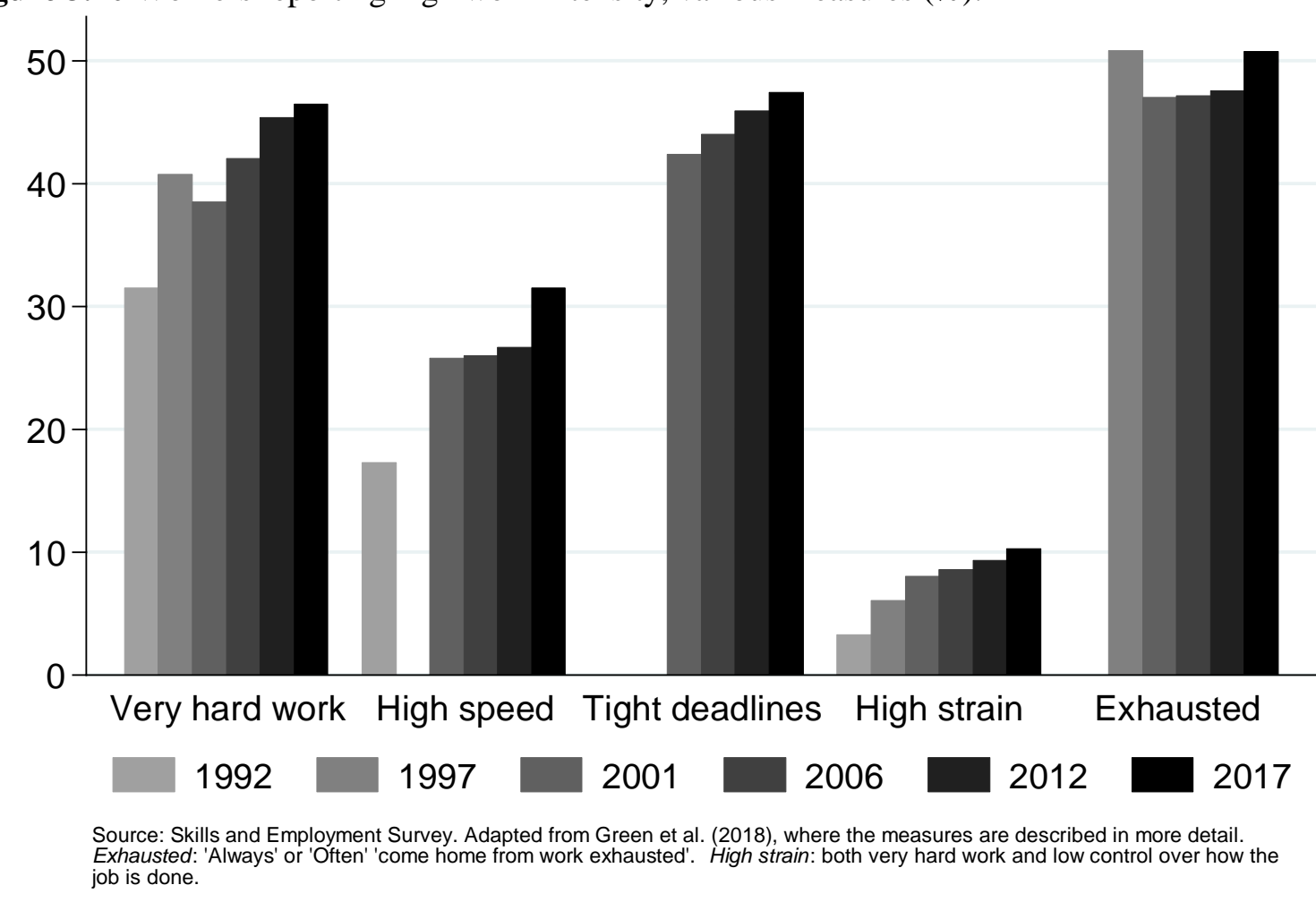

\section{The youth labour market}

The labour market for young people today bears little resemblance to the situation in the 1960s and 1970s, when most Baby Boomers left school - and for the most part were employed - by age 18. Like most of its OECD peers, the UK now struggles with structurally high youth unemployment. ${ }^{25}$

The polarisation of the labour market described above may have been particularly important for young people, and especially those looking to enter the workforce after leaving school. Many of the jobs towards the middle of the wage and skill distributions which have disappeared - skilled manual jobs and mid-level white-collar jobs such as credit agents and bookkeepers - lent themselves to taking on and training school leavers, often through apprenticeships, and offered those school leavers a decent income and economic security. Salvatori's analysis of job polarisation notes that 'by far the largest positive contribution to growth of employment in low-pay occupations has come from the reallocation of native non-graduates from middling to bottom occupations' (2018: 11) ${ }^{26}$ Mid-level jobs have far from disappeared altogether, but young people are increasingly faced with a choice between lowskilled, low-wage work, and further or higher education as a necessary prerequisite for better work but not a guarantee of it.

For the Baby Boomer generation, apprenticeships played an important role in the school-to-work transition. At their peak in the mid-1960s, around a third of male school leavers aged 15-17 went into one (Evans, 2011). As discussed in the previous chapter, however, traditional apprenticeships fell into

\footnotetext{
${ }^{25}$ To be clear, people in education are counted as outside the labour market and therefore do not count towards unemployment statistics - so this is largely an issue of unemployed school-leavers.

${ }^{26}$ As the mention of natives here suggests, Salvatori considers the role of immigration in occupational change. His conclusion is that 'The increase in the number of immigrants, on the other hand, does not account for any particular aspect of the polarisation in the UK' (2018: 1).
} 
a long decline, and the attempt to revive them in the 1990s resulted in many poor-quality programmes only loosely related to 'apprenticeship' as traditionally conceived.

Wolf describes the 'vanishing youth labour market' (2011: 24) that characterises the UK and other OECD countries. In addition to the broader trends already mentioned, she cites the introduction of labour market regulations that make it more difficult for employers to dismiss workers and therefore disincentivise them from taking on younger workers without a strong record of prior employment. Health and safety concerns have also been cited as a disincentive to taking on 16- and 17-year-olds as apprentices or employees. The effect of minimum wage legislation on youth employment is a hotlydebated topic, but the evidence tends to indicate 'extremely small' negative effects, especially where there is a separate subminimum rate for young people, as in the UK (Croucher \& White, 2011: 8). Finally, a reluctance to employ young non-graduates also emerges organically from the self-reinforcing process of educational expansion discussed in the previous section: "the more young people stay in education, the more employers perceive the remainder as 'low quality'. This does not mean these young people are, necessarily, without the skills needed to do the jobs they are applying for - but they are perceived as likely to be' (Wolf, 2011: 30).

\section{An oversupply of graduates?}

As strong as the trend of occupational upgrading has been, an important question is whether educational expansion may have actually outpaced it: is the increase in graduate numbers matched by a corresponding increase in jobs requiring a degree? Measuring whether a job 'needs' a degree is inevitably a difficulty. But with that in mind, the percentage of jobs rated by the workers in those jobs as requiring a degree has risen from 10\% in 1986 to 29\% in 2017, with a further 9\% (stable over time) requiring professional qualifications (Gallie et al., 2014; Henseke et al., 2018). Since 2012, however, Henseke and colleagues find that the growth of demand for high-level skills and a graduate qualification has slowed, 'and even reversed in some domains' (2018: 1).

This slowdown while educational expansion has continued apace suggests an oversupply of graduates. Another approach is to look at change in the percentage of graduates employed in non-graduate jobs. This is shown in Figure 3.11, with the classification of jobs into graduate and non-graduate made according to whether the tasks involved normally require knowledge and skills developed in a university degree (Elias \& Purcell, 2013). ${ }^{27}$ Of those who graduated in the past five years, almost half are not in graduate employment, a proportion which has risen steadily since 2001.

\footnotetext{
${ }^{27}$ This may seem obvious, but it aims to draw an important distinction between jobs that require a degree and jobs in which most workers happen to hold degrees even though they are arguably unnecessary - estate agents being a prime example according to Elias and Purcell.
} 
Figure 3.11 Graduates in non-graduate employment (\%).

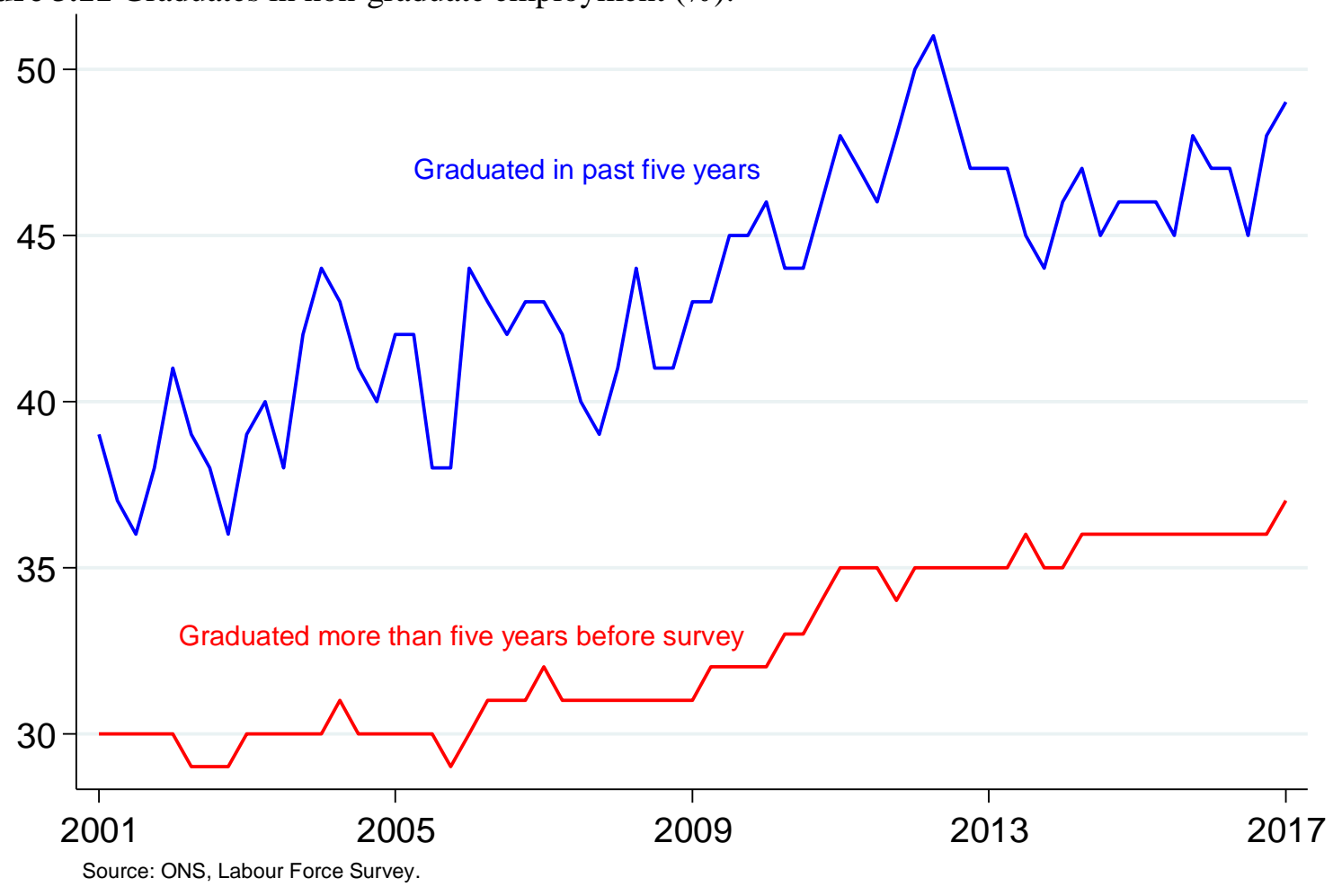

Green and Zhu (2010) also examine this trend, but make a distinction between two forms of overqualification: 'real' overqualification, where graduates in non-graduate jobs report that in their work they can make use of only 'very little' or 'a little' of their experience, skill, and abilities; and 'formal' overqualification, where employees are similarly overqualified educationally but in contrast report that their skills are being utilised to a substantial degree. ${ }^{28}$ Their finding is that overall overqualification rose from just over $20 \%$ of graduates in 1992 to about $33 \%$ in 2006, and that this was mainly driven by formal overqualification. This suggests not just a glut of graduates, but of graduates without particular skills ready to be deployed in graduate jobs. Another implication is that graduates are increasingly taking their pick of the non-graduate jobs they find challenging and desirable. ${ }^{29}$

This oversupply of graduates has important implications for non-graduates. Because of the labour market value of a degree, many non-graduates find themselves almost automatically overlooked for non-graduate roles in favour of graduates. As Goodhart (2020) observes, the more defensible position for recruiters and managers is always to pick a graduate over a non-graduate. Importantly, this also implies a new glass ceiling for non-graduates who might in the past have worked their way up in an organisation to a higher-level role.

\footnotetext{
${ }^{28}$ Respondents are counted as utilising rather than underutilising their skills if they say 'quite a lot' or 'almost all' rather than 'very little' or 'a little' in response to the question 'How much of your past experience, skill and abilities can you make use of in your present job?'

${ }^{29}$ Chevalier and Lindley (2009) also report a large increase (in fact a doubling) in what they term 'overeducation'. They compare those who graduated in 1990 and 1995, and so essentially focus on the effect of the 1992 wave of higher education expansion.
} 


\section{Generational comparisons: employment status}

What have these underlying, long-term trends ultimately meant for the experience of different cohorts when we compare them at the same age?

Figure 3.12 Economic status at age 18, by sex and birth cohort (\%).

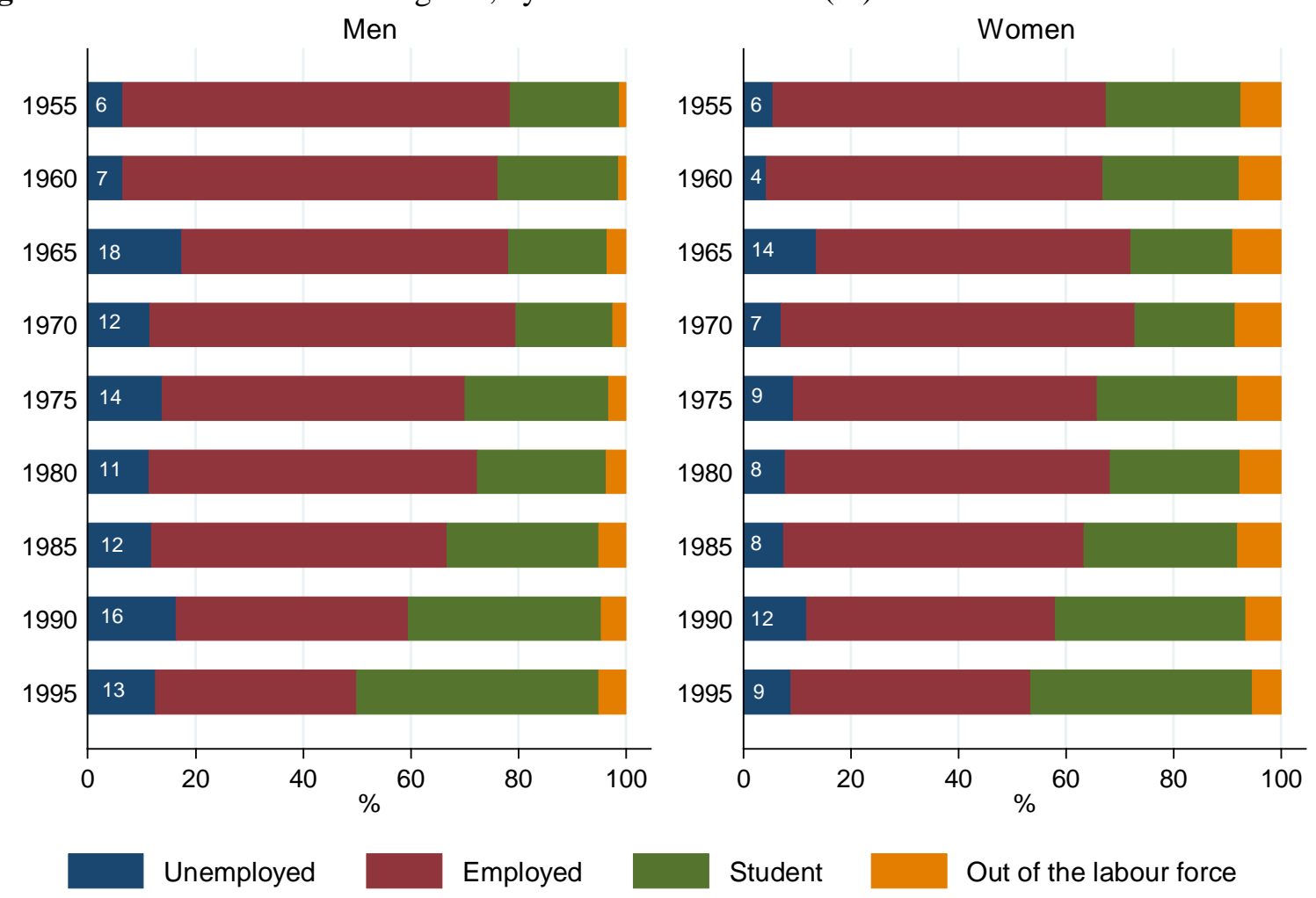

Source: ONS, Labour Force Survey 1975-2020. 1955: born 1955-1959, etc.

Research suggests that unemployment early in one's working life carries substantial disadvantages, setting people's earning power back and putting them at risk of poor health, social exclusion, and further worklessness (Bell \& Blanchflower, 2011; Gregg, 2001; Gregg \& Tominey, 2005; Strandh et al., 2014). So youth unemployment is a major concern.

Figure 3.12 shows the make-up of economic status at age 18, grouped by five-year birth cohorts. Unemployment is the leftmost of the categories, coloured blue and with its percentage also shown as a number. Baby Boomer cohorts saw very low levels of unemployment at age 18, but this changed for every group thereafter, beginning in fact with those born 1965-1969, among whom 18\% of men and $14 \%$ of women were unemployed. The figure also charts a decline in employment and increase in study at this age. A small but growing number of men not in education are not only not employed but out of the labour force altogether - in other words, not seeking work. This group comprised 5\% of 18 -yearolds born 1995-1999. ${ }^{30}$

\footnotetext{
${ }^{30}$ Among women 'out of the labour force' most often represents raising children.
} 
Figure 3.13 Unemployment rate, by age and birth cohort (\%).

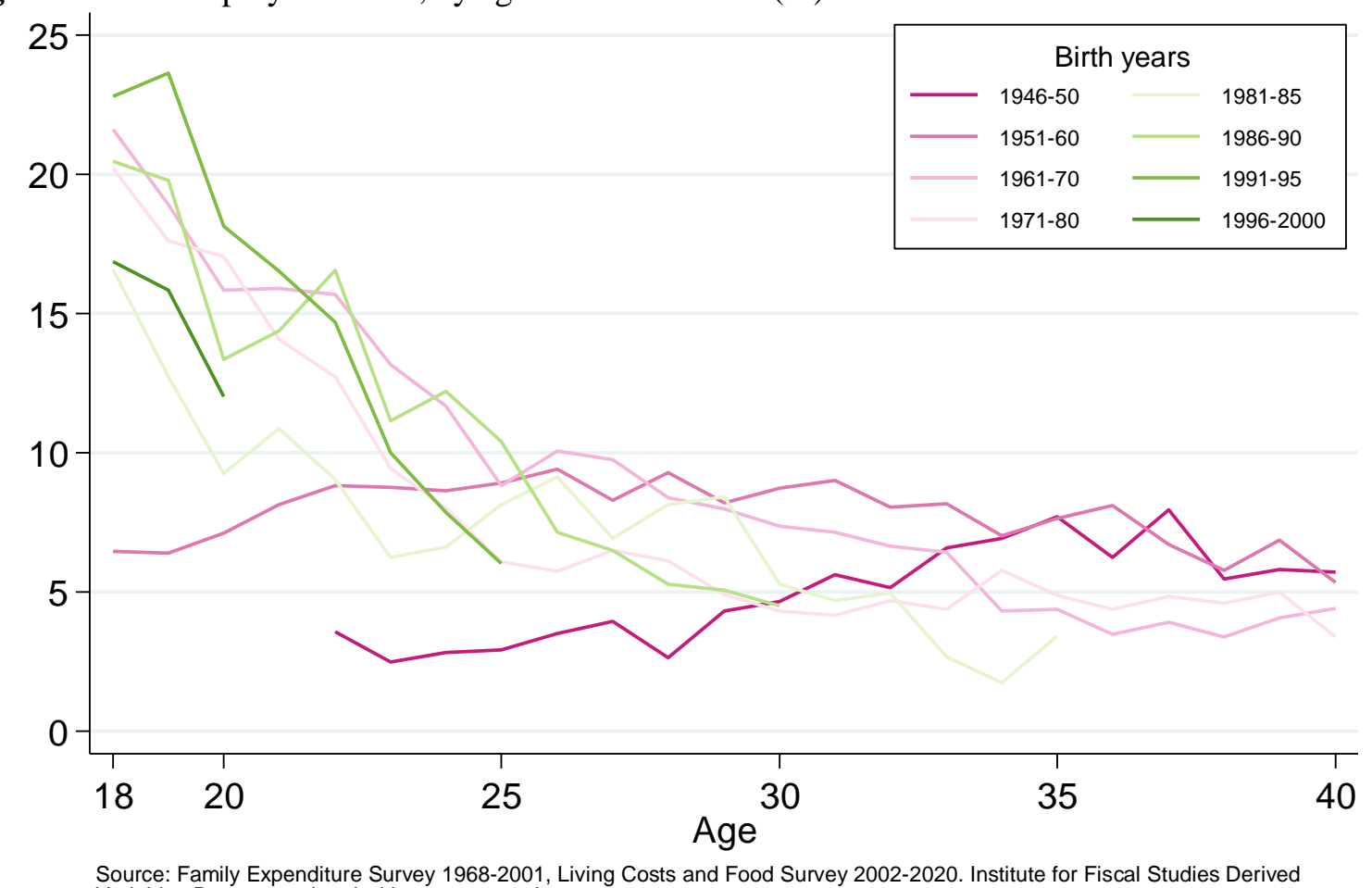

Source: Family Expenditure Survey 1968-2001, Living Costs and Food Survey 2002-2020. Institute for Fiscal Studies Derived Variables Dataset, updated with most recent data.

Figure 3.13 focuses on unemployment and compares birth cohorts across ages 18 to $40 .{ }^{31}$ Each line in this sort of figure represents those born in a particular five- or ten-year window. The dark purple line is the oldest birth cohort shown (in this case those born 1946-50), and as the colours change from dark purple to paler purple, to pale green and finally to dark green, so the birth cohorts represented are younger and younger, ending with those born 1996-2000. Note that to make some figures - including this one - more readable, I have combined everyone born in the 1950s into a single group, and done the same for the 1960s and 1970s. Overlaying these lines gives us a detailed picture of generational change.

Figure 3.13 echoes what we saw in Figure 3.12: youth unemployment was exceptionally low among Baby Boomer cohorts, and much higher for subsequent generations. The younger end of the Millennial cohort had the highest unemployment rate from 18 to 21 . This shows that labour market conditions have been very challenging for those choosing to go to work at a time when higher education is increasingly the norm. Not far below, however, are the older end of the Baby Boomer cohort and Generation X: these groups also contended with high youth unemployment.

Unemployment is associated with a range of personal and social harms at any age (Brand, 2015) - so what does the figure tell us about older ages? From about 25 onward, we see a somewhat different picture. The broad result that stands out is that Millennials are no longer any more likely than other groups to be unemployed at a given age, albeit we only know about those born in the early 80 s up to age 35 and those born in the late 80s up to age 30. This pattern reflects the high unemployment of the 1980s and early 90s, which even the Covid pandemic and aftermath of the financial crisis did not match.

\footnotetext{
${ }^{31}$ Note that the unemployment rates shown in Figure 3.13 are the percentage unemployed out of all those in the labour force (which does not include students), whereas the unemployment numbers in Figure 3.12 are the percentage unemployed out of everyone (including students and those out of the labour force for other reasons).
} 
Figure 3.14 NEET (not in education, employment, or training) status among men, by age and birth cohort $(\%)$.

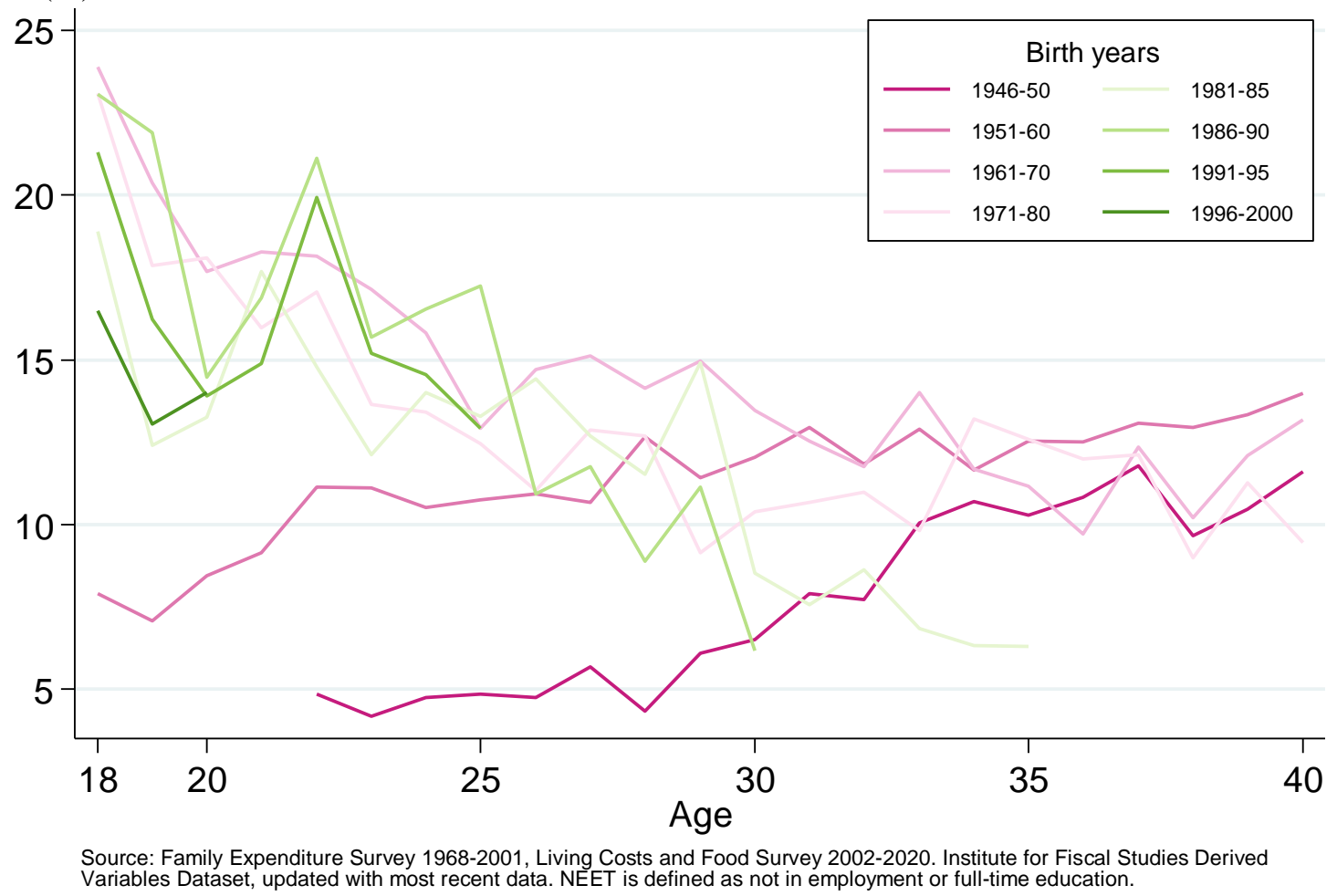

Because the unemployment rate only tells us about people working or who want to work, it ignores students and others not seeking work. Seeing a high youth unemployment rate at a time of educational expansion might then make us wonder: maybe more people than ever have been working or studying, meaning generational differences are actually small? We can answer this question - for men at least by looking at what percentage of the whole cohort are 'NEET' - that is, not in employment, education, or training. ${ }^{32}$ In addition to the unemployed, this measure will pick up 'discouraged workers' who are able to work but are neither working nor seeking a job, as well as those inactive for other reasons. For women it makes less sense to use this measure because women raising children would be included among the NEET, and it is certainly debatable whether that is what we want the measure to do.

In Figure 3.14, then, I look at NEET status among men across the generations. The concern raised appears unfounded. The picture is extremely similar to the unemployment story, despite the increasing numbers staying in education for longer: until about age 25, every cohort from those born in the 1960s onwards has seen high levels of unemployment or inactivity. From this age onwards, it appears that the older Millennials are reaching historically low levels of NEET.

\section{Generational comparisons: earnings and career progression}

Figures 3.15 and 3.16 compare the generations in terms of median earnings, adjusted for inflation to be comparable. Figure 3.15 comes from the work of Cribb (2019) while Figure 3.16 shows my own estimates. There are slight differences in our approaches and we have used different data sources, but our results tell the same story.

\footnotetext{
32 This is an imperfect measure of NEET status because for older generations at younger ages we are dependent on older surveys which did not collect data about part-time educational courses or training schemes. Instead only a measure of full-time education is available.
} 
Figure 3.15 Median annual pre-tax earnings of those in paid work, by age and birth cohort ( $£$ thousands, 2017-18 prices).

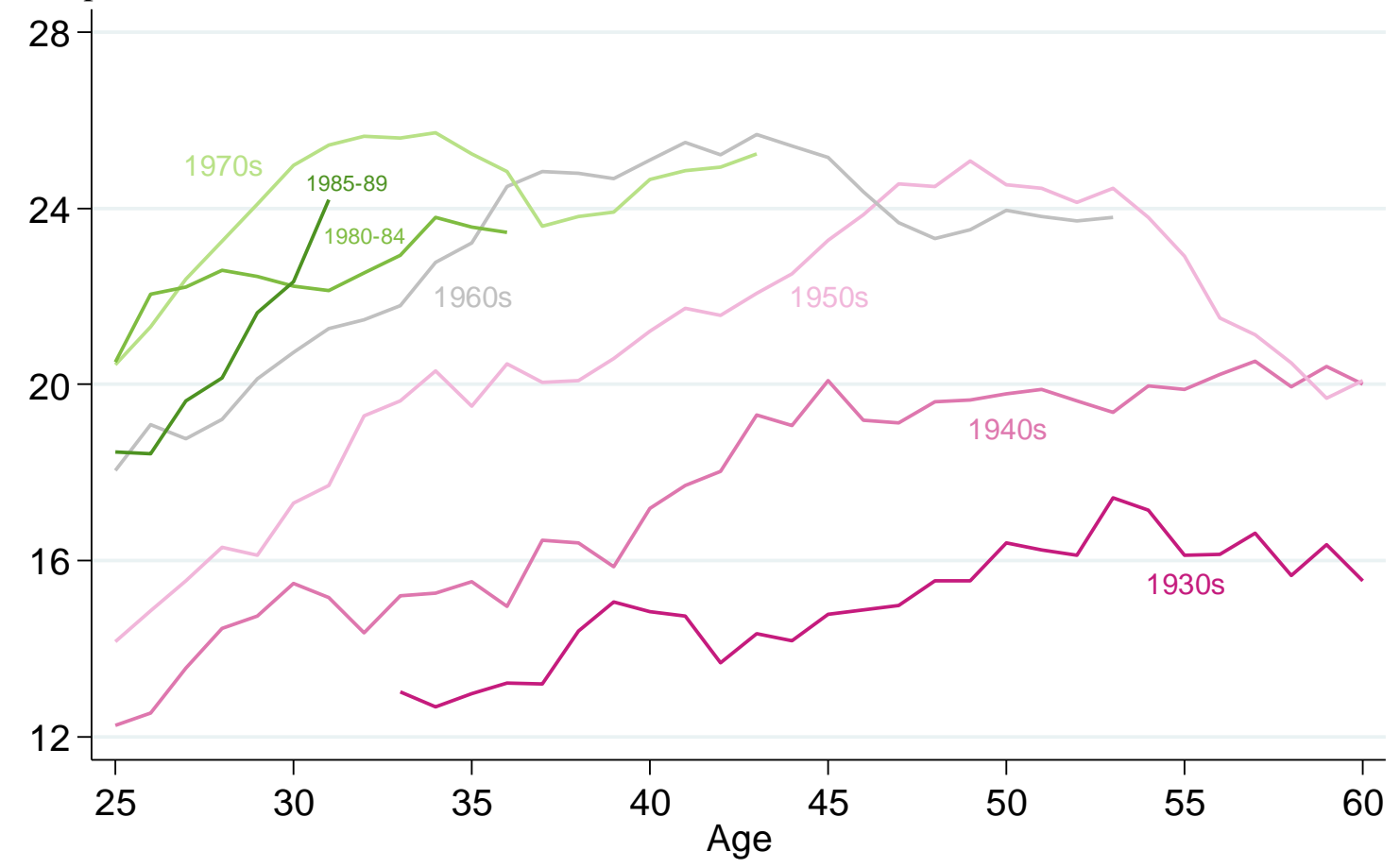

Source: adapted from Cribb (2019).

Figure 3.16 Median monthly pre-tax earnings of those in paid work, by age and birth cohort ( $£$, Jan 2020 prices).

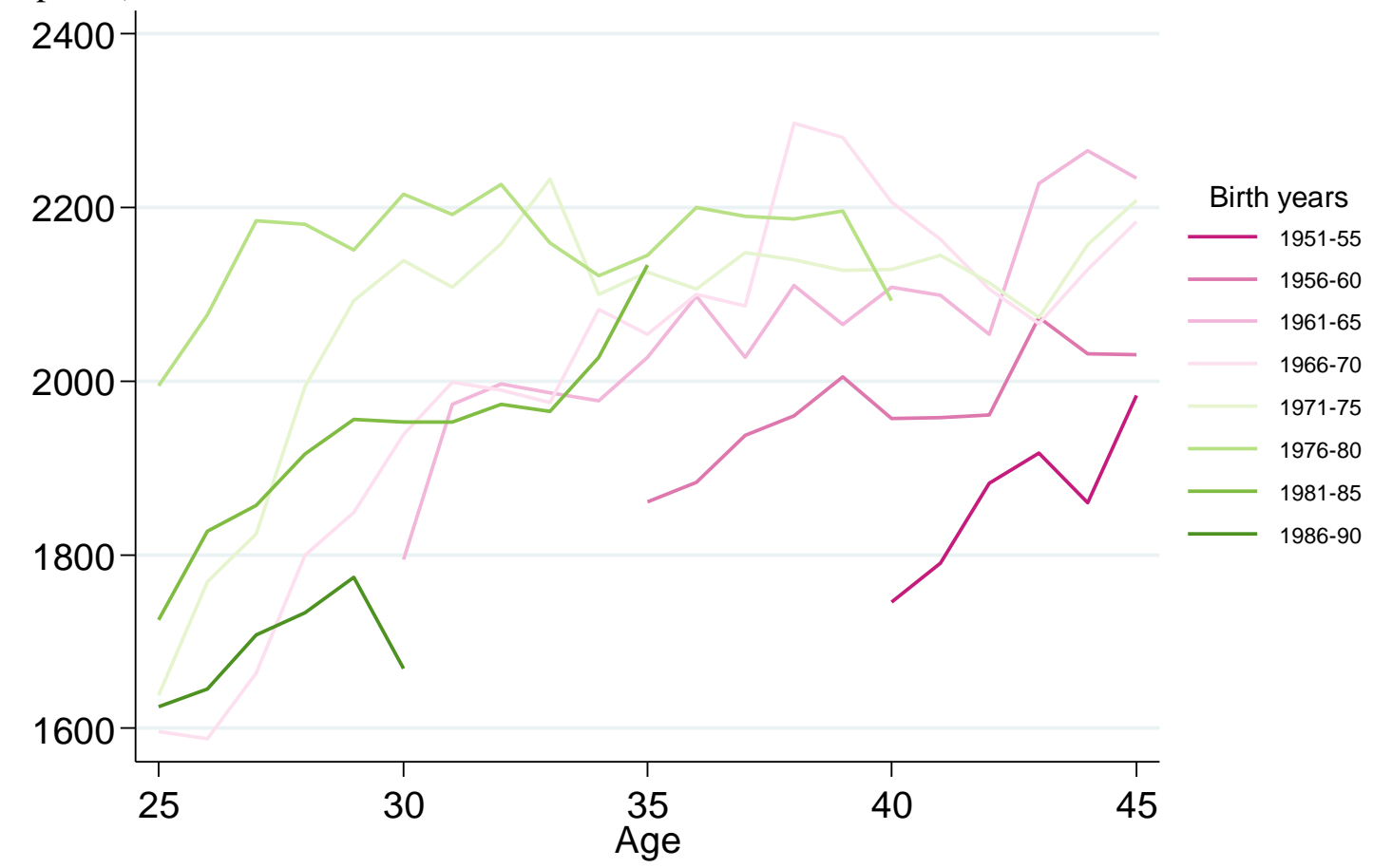

Source: British Household Panel Survey 1991-2008, UK Household Longitudinal Study 2009-2019. 
At every age, those born in the 1940s had substantially higher earnings than those born in the 1930s. The 1940s cohort were overtaken by the 1950s cohort to an even larger degree. The 1960s cohort in turn saw greater earnings than those born in the 1950s, at least until around age 45. Those born in the 1970s had been seeing similar progress, until from age 35 their earnings ceased to grow, and only matched rather than exceeded the 1960s cohort.

The trigger for this slowdown in each cohort's wage growth, as we have seen, was the financial crisis. The 1980s cohort were in their 20s when it hit - just getting started in the labour market - and this can be seen in their earnings relative to earlier cohorts. At ages 25-35, the earnings of those born in the 1980s is well below that of the 1970s cohort, and in fact looks very close to the 1960s cohort. This still means substantially higher earnings over young adulthood than those born in the 1950s and earlier but it is striking that generation-on-generation progress has stalled and even gone into reverse. ${ }^{33}$

Figure 3.17 Mean occupation pay rank of initial job, five years later, and ten years later, by sex and birth cohort.

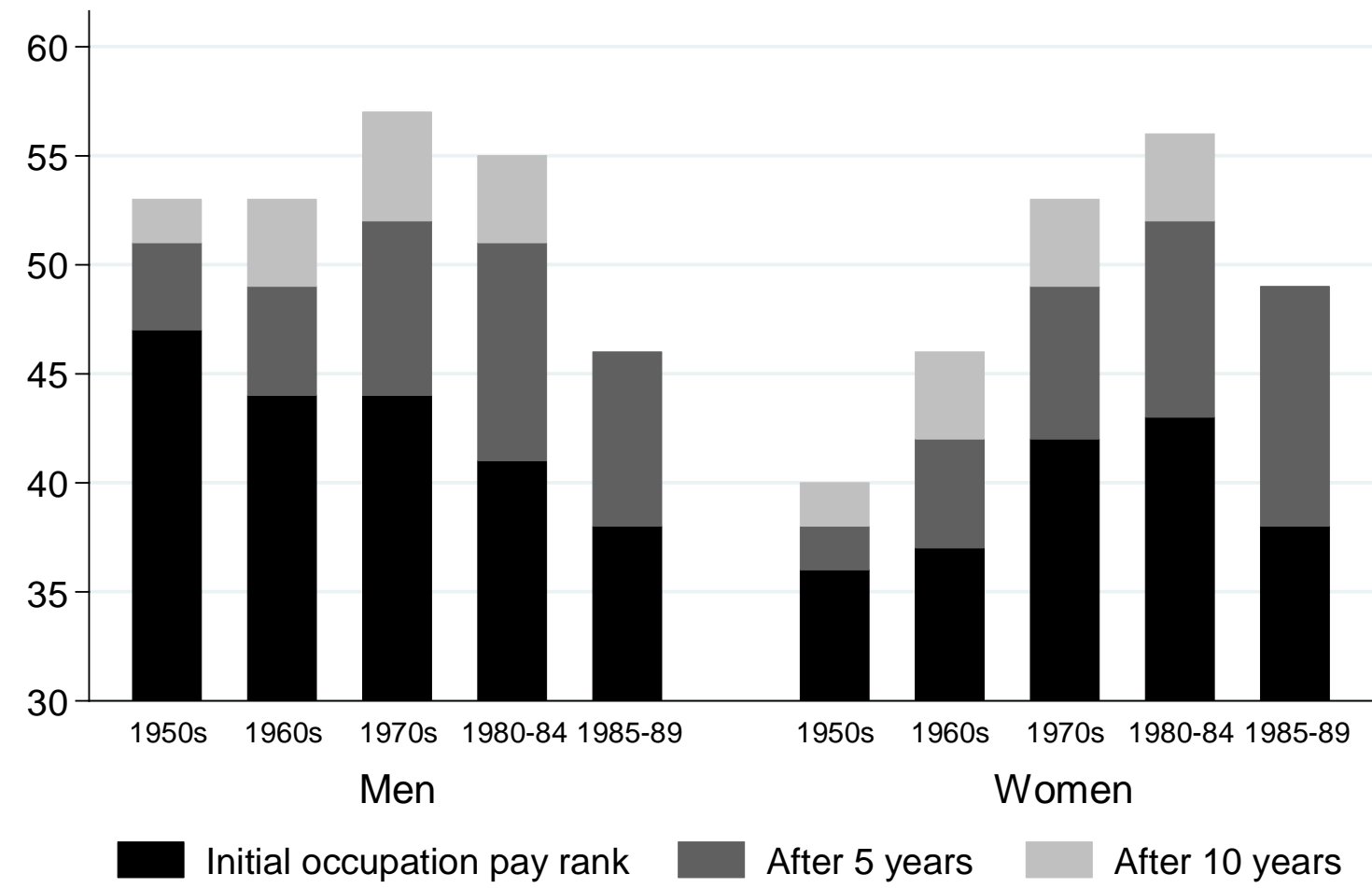

Source: adapted from Blundell et al. (2020)

Two reasons for 1980s-born workers falling behind 1970s-born workers is that they are starting in lower-paid occupations, and they are not seeing the same rate of career progression in terms of their pay. Figure 3.17, from Blundell et al. (2020), shows these patterns. Their analysis first sorts occupations into 100 groups, ranked from the lowest to the highest-paid. It then looks at where, on this 1-100 scale, each birth cohort is entering employment (on average). As the black bars show, men in successive cohorts have been starting their working life in lower-ranking occupations. Women had been rising, but this reversed with the late-80s cohort. 'When compared with those born in the 1970s', Blundell et al. write, 'men born in the late 1980s were at least twice as likely to have been bar staff, kitchen and

\footnotetext{
${ }^{33}$ Cribb (2019) separately analyses trends in income specifically, and the conclusions are highly similar. Earnings (money earned from employment) is a narrower concept than income. The latter also includes other sources of income besides earnings, such as benefits, pensions, and investment income. Earnings is by far the most important component of income for working age adults.
} 
catering assistants, or call centre workers in their first full-time job; and women were about twice as likely to have been waitresses or care workers' (2020: 2).

The lighter-shaded parts of the bars show how things change after five and then ten years in work. Unlike those born in the early 80s, the 1985-89 cohort have not been able to catch up by moving into better-paying occupations. After five years in work, men born 1985-89 are in occupations that rank similarly to those in which the 1950 s cohort started work.

This brings us back to the discussion of occupational upgrading and polarisation discussed earlier. We saw that occupational upgrading has been the main overall trend in the labour market - but polarisation is the most important consideration when characterising the experience of recent cohorts.

As Figures 3.18 (men) and 3.19 (women) show, every cohort from those born in the 1940s onward has had a greater likelihood of working in a high-paid occupation at a given age - until the 1980s cohort (Cristini et al., 2018). This pattern is especially clear for men, among whom the youngest cohort are about as likely to be in high skill work at age 30 as were those born in the 1950s and 60s.

But most concerning is what has been happening below the high-paid occupations. As these figures also show, at least from age 20 to 30 , both men and women born in the 1980s have been far more likely to be employed in low-pay, low-skill occupations and correspondingly far less likely to be in middling occupations (Cristini et al., 2018). At age 25, for example, 30\% of men born in the 1980s were in low skill work, compared with $18 \%$ of the 1950 s cohort.

Figure 3.18 Share of workers employed in low, medium, and high skill jobs, by age and birth cohort: men $(\%)$

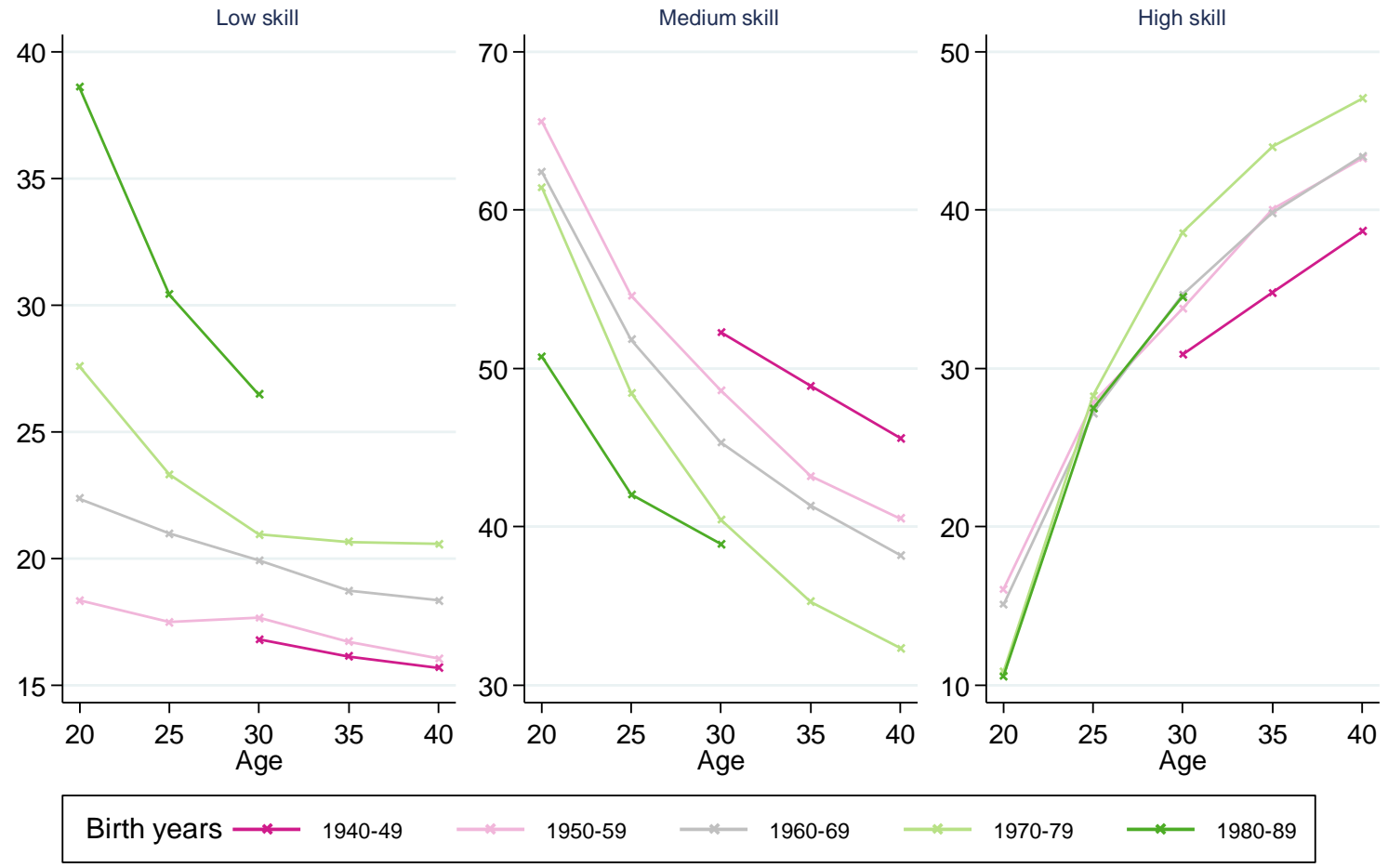

Source: adapted from Cristini et al. (2018), ONS New Earnings Survey and Annual Survey of Hours and Earnings, 1975-2015. The SOC90 classification of occupations is the basis for distinguishing broad groups according to skill level. Low consists of SOC90 categories 6 (Persona and protective), 7 (Sales), and 9 (Other). Medium consists of 4 (Clerical and secretarial), 5 (Craft and related), and 8 (Plant and machine operatives). High consists of 1 (Managers and administrators), 2 (Professional), and 3 (Associate professional and technical). Points for 1980-89 at age 30 represent those born 1980-1985 only. 
Figure 3.19 Share of workers employed in low, medium, and high skill jobs, by age and birth cohort: women $(\%)$.

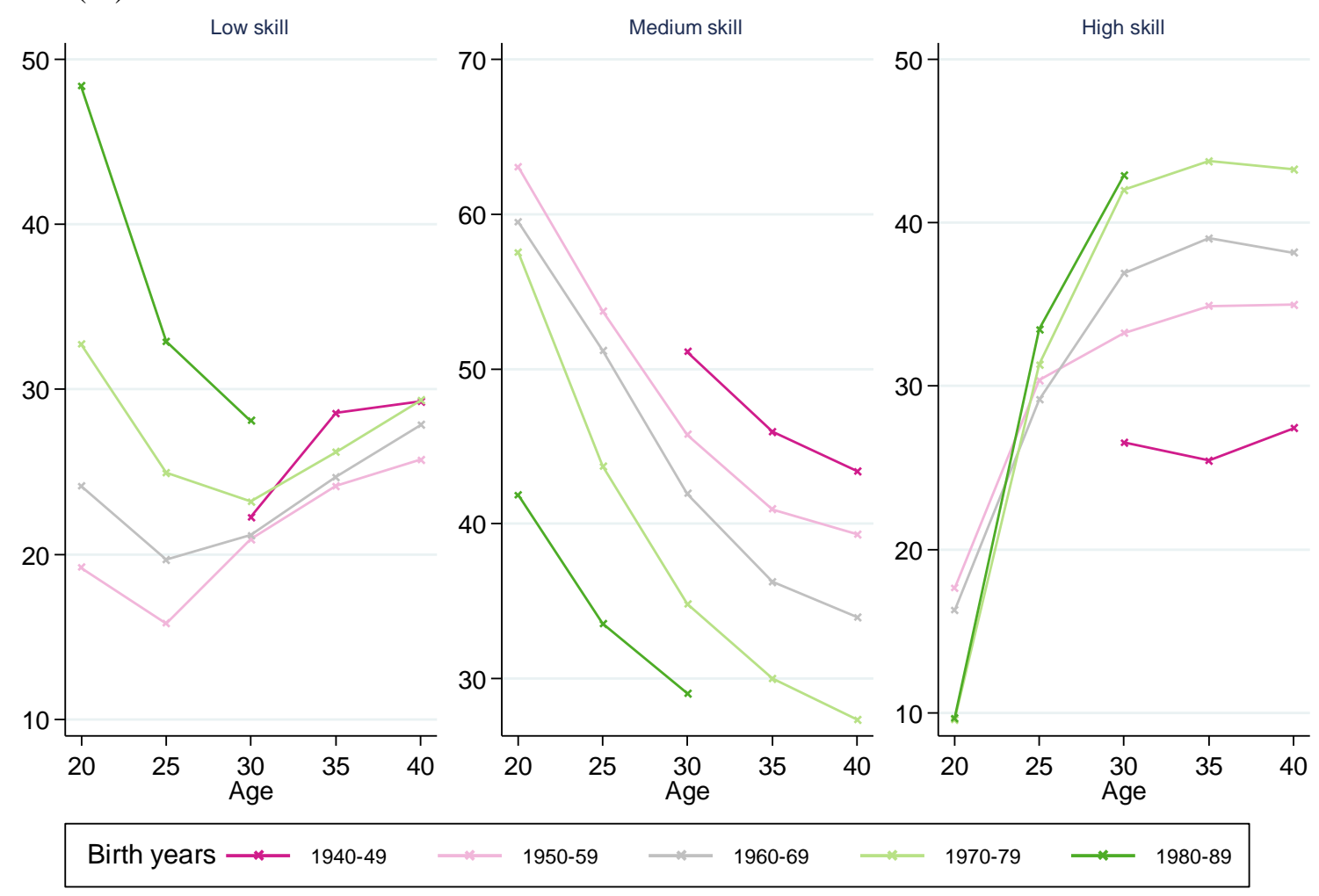

Source: adapted from Cristini et al. (2018), ONS New Earnings Survey and Annual Survey of Hours and Earnings, 1975-2015. See figures above for details of low, medium, and high skill groups. Points for 1980-89 at age 30 represent those born 1980-1985 only.

Figures 3.20 and 3.21 similarly break cohorts down into men and women employed in low, medium, and high skill work. These figures show how each group's median earnings compare to overall median earnings (i.e. among all employees). While the results are more mixed for women, among men in medium and low skilled work there is a clear pattern of younger cohorts earning less relative to the average wage than older cohorts did. So it is not as though high demand for low-skill work has led to higher relative pay for these occupations. 'Thus,' conclude Cristini et al., 'for both relative wages and employment, these trends suggest a generational contraction of job opportunities for men not in top occupations' (2018: 201).

Another way to think about the intergenerational contrast in the labour market is through the lens of social mobility - in this case, in the sense of whether your social class (NS-SEC, based on your job as described above) is a step up, the same, or a step down relative to your parents at the same age. Thanks to occupational upgrading, there is now more 'room at the top' of the class structure. But that also means increasing numbers of young people with parents at the top of the class structure, and keen not to fall. There are limits to how far occupational upgrading can go, and indeed its pace has slowed. Accordingly, decreasing numbers of young people are experiencing upward intergenerational mobility, while increasing numbers - as many as a third of those born 1980-84 - are experiencing downward mobility relative to their parents (Bukodi \& Goldthorpe, 2019). Intuitively this would appear a source of malaise and disappointment; the extent to which such an experience is harmful to health and discourages childbearing are each debated topics (Easterlin, 1976; Macunovich, 1998; Präg \& Richards, 2019). 
Figure 3.20 Earnings relative to average earnings: men. (Log median earnings ratio for age-cohort-skill group relative to median earnings of all employees.)

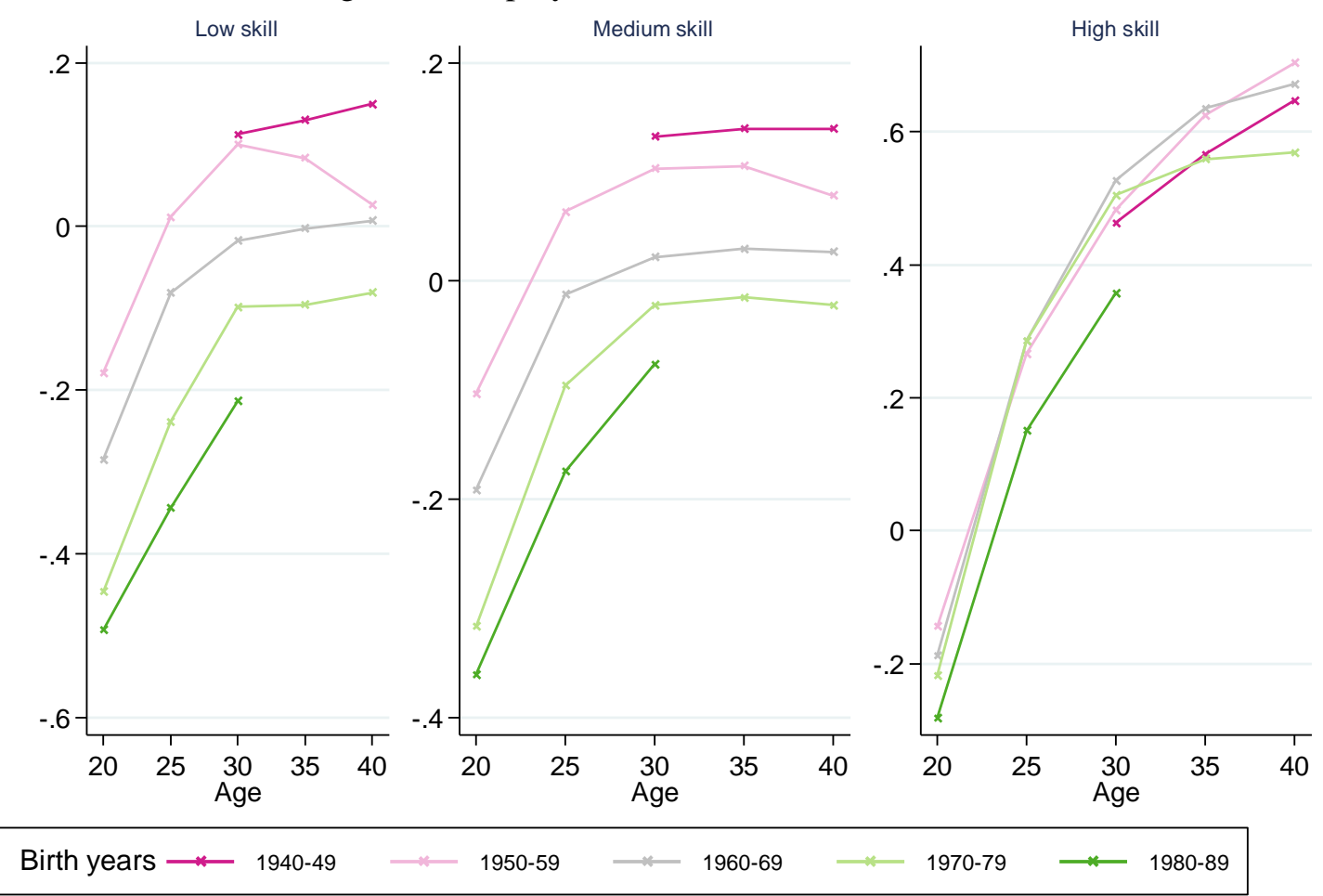

Source: adapted from Cristini et al. (2018), ONS New Earnings Survey and Annual Survey of Hours and Earnings, 1975-2015. See figures above for details of low, medium, and high skill groups. The vertical axis is the ratio of the median of the group's earnings to the median of all employees' earnings (expressed in logs meaning that 0 indicates the group earns the overall median wage). Points for 1980-89 at age 30 represent those born 1980-1985 only.

Figure 3.21 Earnings relative to average earnings: women. (Log median earnings ratio for age-cohortskill group relative to median earnings of all employees.)

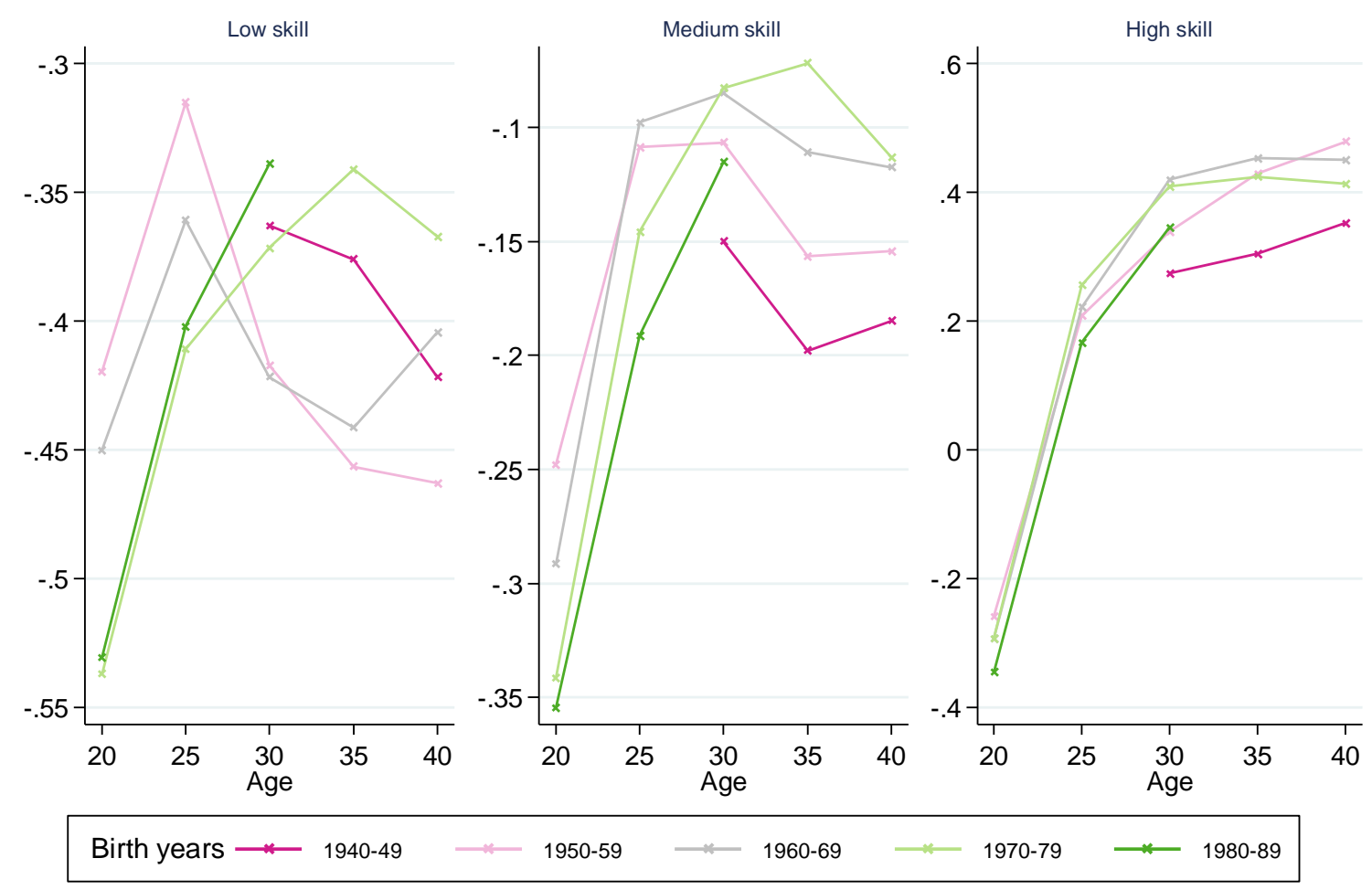

Source: adapted from Cristini et al. (2018), ONS New Earnings Survey and Annual Survey of Hours and Earnings, 1975-2015. See figures above for details of low, medium, and high skill groups. The vertical axis is the ratio of the median of the group's earnings to the median of all employees' earnings (expressed in logs meaning that 0 indicates the group earns the overall median wage). Points for 1980-89 at age 30 represent those born 1980-1985 only. 


\section{Generational comparisons: job security and hours}

What about other aspects of employment? Job insecurity is much discussed, and for good reason: this kind of uncertainty is stressful and poses an obstacle to long-term plans such as settling into a home, getting married, and having children. Figure 3.22 shows the percentage of people reporting that their current job is not a permanent one, for instance because it is temporary or seasonal work. The available data unfortunately do not allow us to look at the situation of Baby Boomers before the age of about 30 . But with that limitation in mind, what we see strongly suggests that non-permanent employment is closely linked to age rather than generation. Non-permanent employment is unsurprisingly highest for workers in their teenage years and early 20s, but falls sharply with age and plateaus below $10 \%$ throughout most of working age - for all cohorts alike, insofar as we can tell.

Figure 3.22 Non-permanent employment, by age and birth cohort (\%).

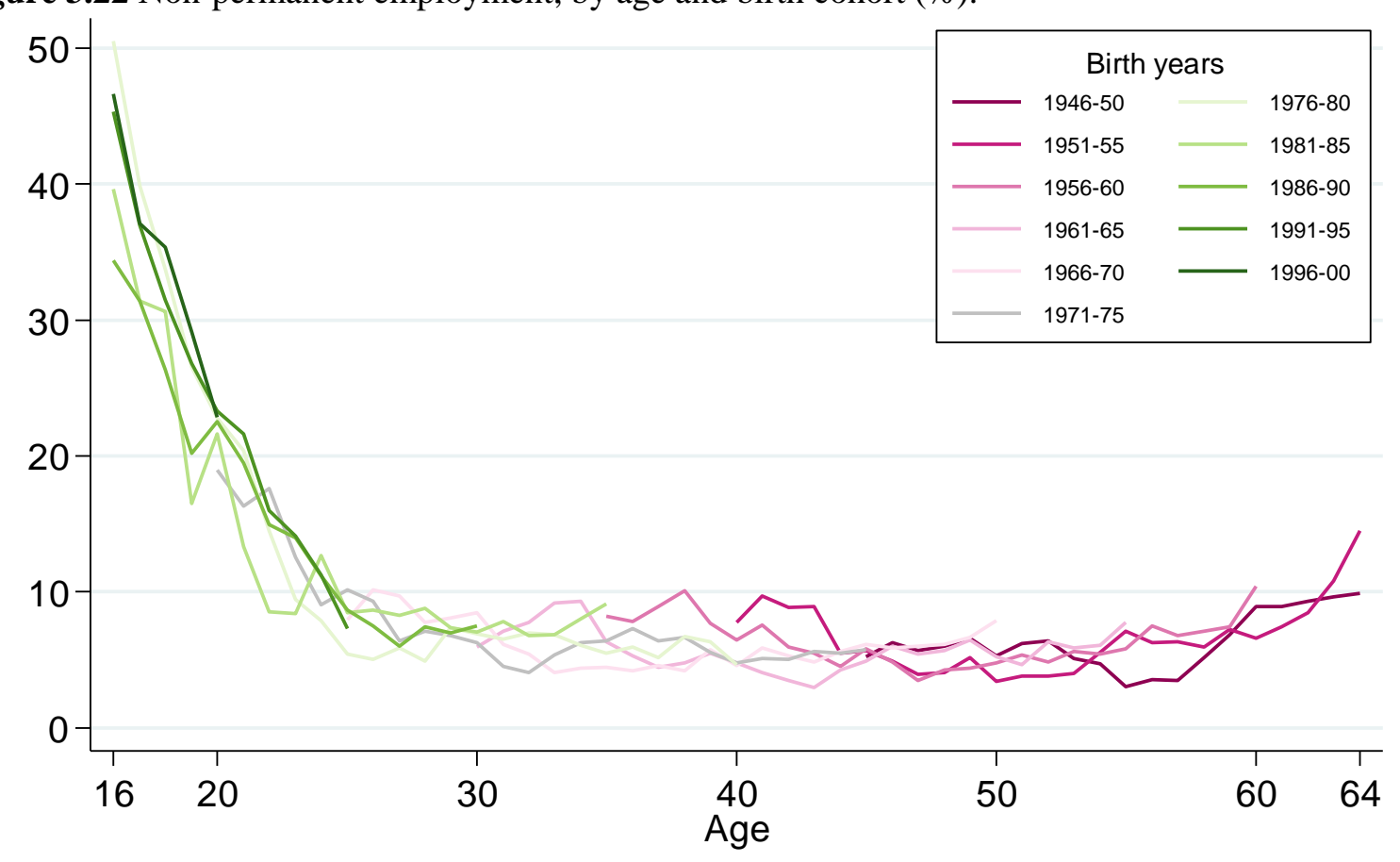

Source: British Household Panel Survey 1991-2008, UK Household Longitudinal Study 2009-2019. Question: 'Leaving aside your own personal intentions and circumstances, is your job...' (1) A permanent job (2) Or is there some way that it is not permanent? (Question slightly different 1991-1998.)

Figure 3.23 looks at the same question from a slightly different angle. The survey question here asks respondents to consider how likely they think it is that over the next 12 months they will be sacked, laid off, or not have their contract extended. This gives us a measure of subjective job security. This is relatively recent data, covering only 2009-2019, meaning that we only see overlap between adjacent five-year cohorts and can't make comparisons at the level of generations.

Whereas in the previous figure, on temporary employment, the trend strongly pointed to the importance of age, here the results strongly suggest a common 'period effect' - people of all ages and cohorts have similarly felt increasingly safe in their jobs over the past decade, albeit with a recent downturn among older workers. It is also striking that in absolute terms it is younger workers - especially Millennials in their 20s - who have been feeling safest in their jobs. This conclusion should not be taken too far, but it does stand in contrast to common narratives of ever-greater job insecurity. ${ }^{34}$ It is also perhaps

\footnotetext{
${ }^{34}$ Economic research investigating this in more detail also supports a picture of steady levels of subjective job security at least since the Millennium - although this does not tell us about the experiences of older generations at younger ages (Manning \& Mazeine, 2020).
} 
encouraging that with each generation, the average number of hours worked by full-time workers has fallen gently, from around 42.5 among 30-year-old Baby Boomers to around 40.5 among 30-year-old Millennials (Figure 3.24).

Figure 3.23 Average subjective job security (1-5), by age and birth cohort.

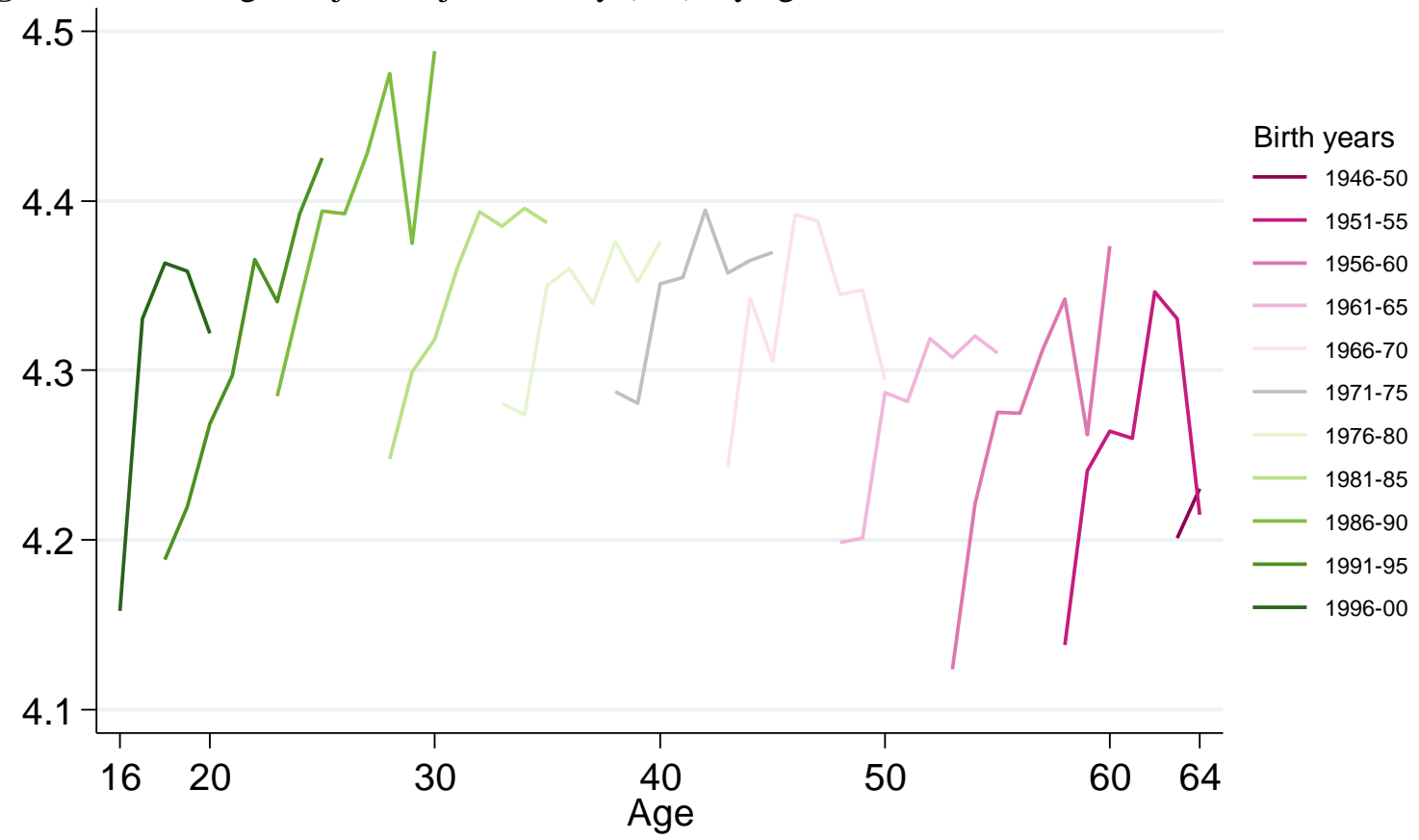

Source: UK Household Longitudinal Study 2009-2019. Question: 'I would like you to think about your employment prospects over the next 12 months. Thinking about losing your job by being sacked, laid-off, made redundant or not having your contract renewed, how likely do you think it is that you will lose your job during the next 12 months? Is it...' (1) Very likely (2) Likely (3) Don't know (4) Unlikely (5) Very unlikely

Figure 3.24 Average hours per week (full-time workers), by age and birth cohort.

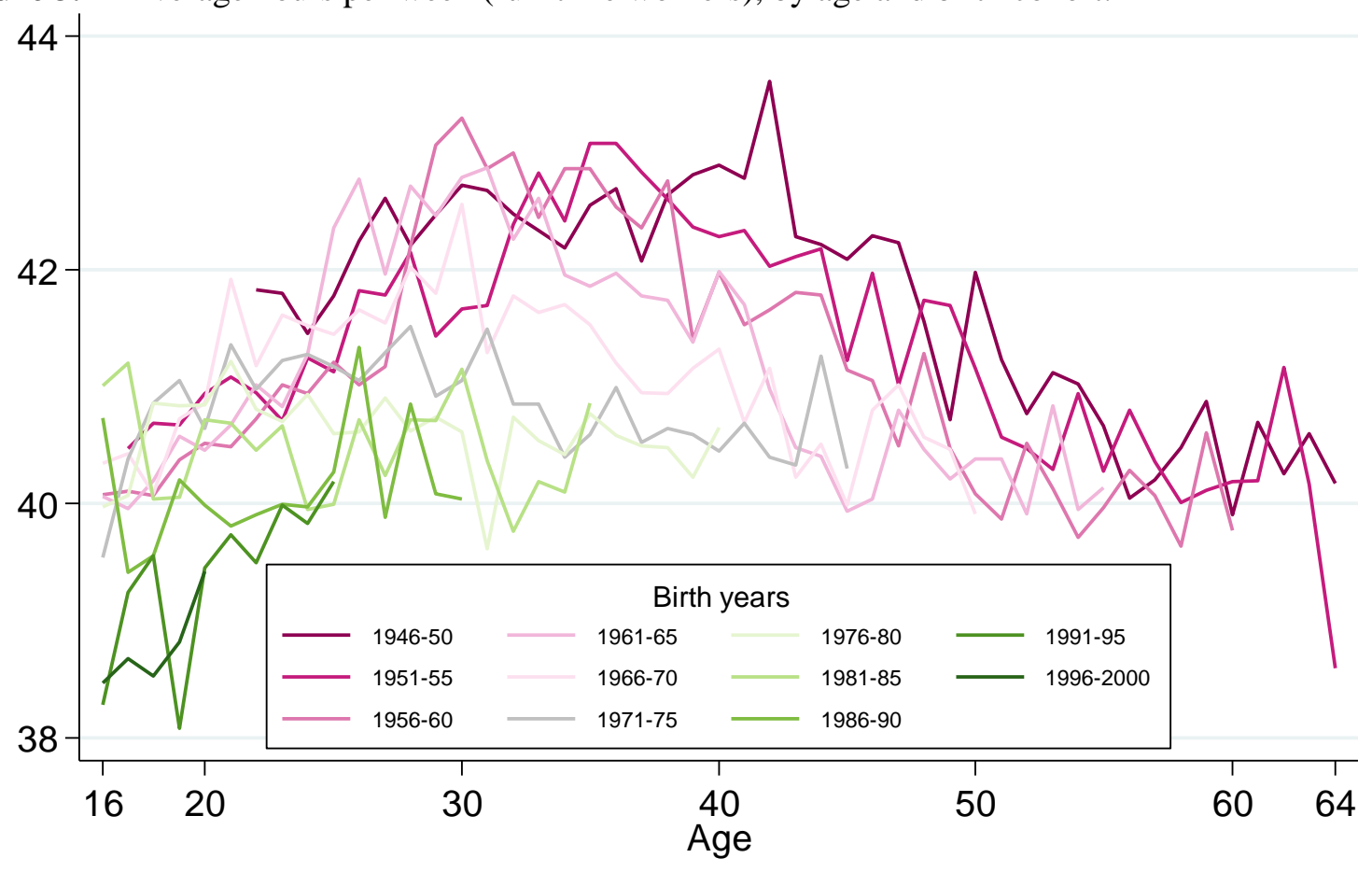

Source: Family Expenditure Survey 1968-2001, Living Costs and Food Survey 2002-2020. Institute for Fiscal Studies Derived Variables Dataset, updated with most recent data. Full-time workers defined as those working 30 hours or more per week. 
The recent phenomenon of zero-hours contracts has given rise to concerns about job security and economic uncertainty among younger generations. Rather than going into any great detail, I will briefly offer some context for these concerns. As of July-September 2021, 3.1\% of UK workers were on such contracts (ONS, 2021c). ${ }^{35}$ Zero-hours contracts are especially prevalent among the youngest $(10.5 \%$ of workers aged 16-24) and oldest (4.5\% of workers aged over 64) parts of the workforce. $61.4 \%$ of those on zero-hours contracts report that they do not want more hours; $22.7 \%$ are in full-time education. Zerohours contracts appear to suit the circumstances of some, but are no doubt also an unwelcome source of uncertainty and stress for others.

Younger generations have not then had it straightforwardly harder or easier on every dimension than those that went before. But they do face some important challenges. A withered youth labour market and continuing educational expansion together put young non-graduates at high risk of unemployment and inactivity, which can set them back for the rest of their lives. Employers highly value work history among prospective employees, and are apprehensive about those who lack it. Moving into their late 20s and early 30s, younger cohorts' unemployment rates have held up well compared with older cohorts. However, low rather than medium skilled work is increasingly the destination of young people without educational credentials. At the same time, those who do earn graduate-level qualifications are increasingly facing stiff competition and dashed career expectations. Career progression has slowed. Stalling productivity at the national level is reflected in stagnant wage growth and even a reversal for Millennials relative to Generation X. The implications of this can only fully be appreciated in the context of the housing market, to which we now turn.

\footnotetext{
35 This represents an estimated 996,000 such workers. This percentage has been fairly stable since 2016. When data on zero-hours contracts were first collected by ONS in 2000, the equivalent figure was $0.8 \%$ of workers $(225,000)$. However, being counted as a zero-hours worker depends on workers recognising this status and answering the survey question accordingly: when zero-hours contracts received less media attention, some workers may not have indicated that this was their contract status.
} 


\section{Housing}

In this section I review the state of the housing market and what this means for different generations. A common thread running through this chapter and the next - on wealth - is that housing has increasingly come to be viewed as an investment and less as a scarce resource meeting a basic consumption need. Would-be owner-occupiers increasingly face competition for houses from those purchasing for investment purposes.

\section{The housing problem}

The UK housing market is often described as 'broken', and housing in a state of 'crisis'. Every market has its winners and losers, and some have done rather well out of housing in recent years. So what, if anything, is the problem?

The problem is that a home with security of tenure is either unaffordable or unavailable for far more young people today than previously, and particularly for those without access to parental wealth. A related but distinct point is that young people also have very low homeownership rates relative to earlier generations. But there are reasonable grounds for arguing either that this is a major problem, or that in itself it is not necessarily a concern.

Agreement amongst experts on housing policy is in surprisingly short supply. I first present a brief outline of the debate and hope to show that the above statement of the problem holds true whichever side you might find more convincing.

\section{The price of houses...}

One clear point of consensus is that, as shown in Figure 4.1, house prices have risen enormously over the past half-century, with much of this growth concentrated in the past 25 years. It is worth emphasising that this increase has far outpaced inflation - Figure 4.1 shows the increase after adjusting for inflation. Across the UK as a whole, the average residential property price is now four times as high in real terms as in 1970, and six times as high in London. This increase has also far outstripped rising household incomes. As also indicated on Figure 4.1, real-terms median income is just over two times as high (as in 1977 , in this case). ${ }^{36}$

The reasons for increasing house prices are the subject of much debate. Broadly speaking, there are two competing explanations. One focuses on demand for housing, driven by rising incomes, population growth, smaller household sizes, ${ }^{37}$ mortgage deregulation, and in particular low interest rates (also shown in Figure 4.1).

Some argue that low interest rates alone can wholly explain UK house price rises (Lewis \& Cumming, 2019; Miles \& Monro, 2019). This reasoning begins by distinguishing housing (a type of asset) from housing services (a roof over your head, whether or not you own that roof). The price of housing services - how much you pay in rent (or could rent out your home for) - is determined by

\footnotetext{
36 The base year is 1977 in this comparison because this is as far back as the ONS has this measure. The specific income measure I have used here is the real-terms disposable household income of the median individual.

${ }^{37}$ While this is sometimes claimed to be important factor, average household size has in fact remained stable at 2.4 from 1996 to 2020. The percentage of one-person households has also changed little, from $27.8 \%$ in 1996 to a peak of $29.5 \%$ in 2019 , before falling back to $28.4 \%$ in 2020 (ONS, 2021a).
} 
straightforward supply and demand. The price of a house is determined by the price of housing services too - the income the asset can produce through rent - but also by the prevailing interest rate. And lower interest rates, all else equal, increase the value of assets. ${ }^{38}$

Figure 4.1 Bank of England base rate (left axis) and inflation-adjusted House Price Index for UK and London (right axis, 1970=100).

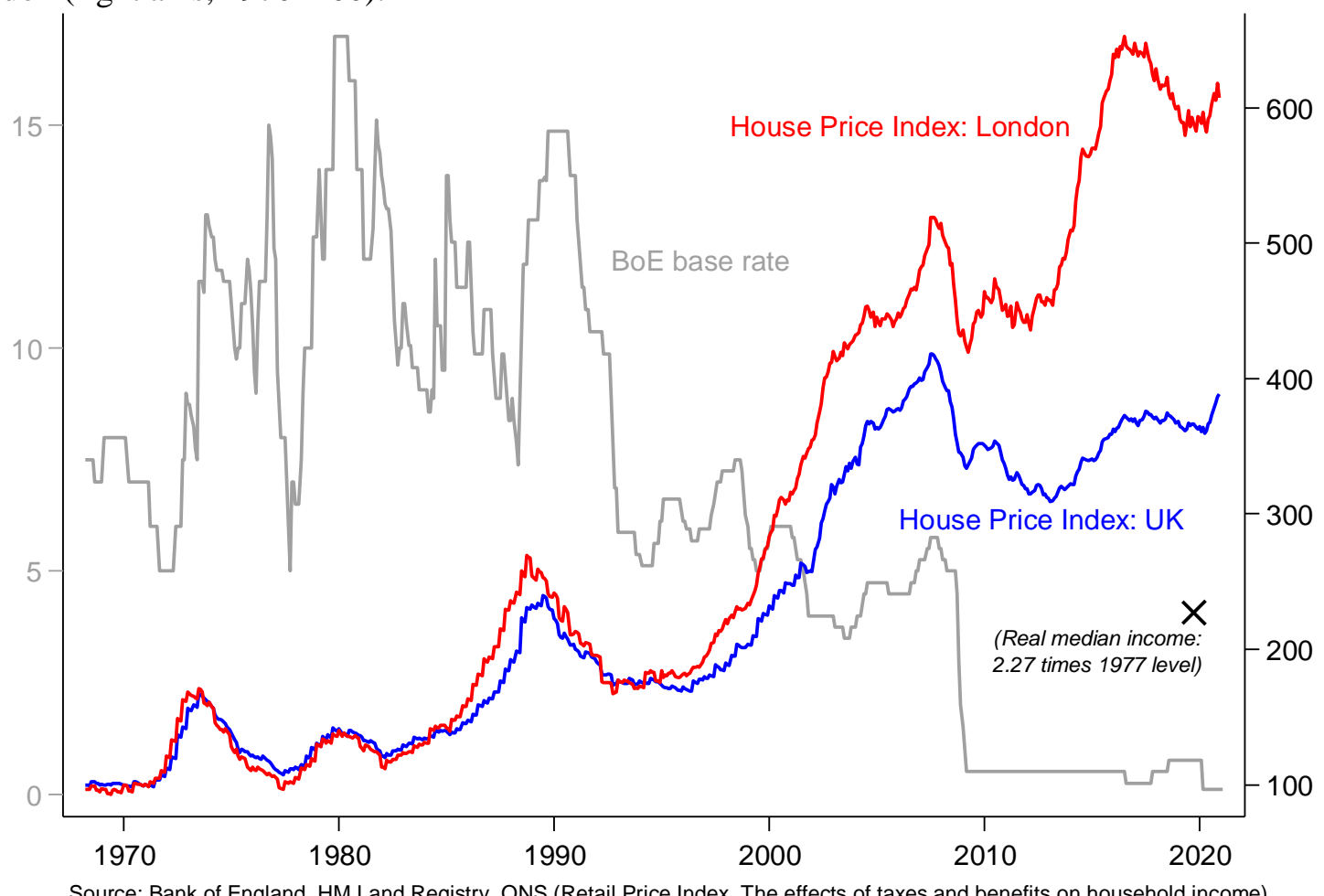
Real median income: median equivalised household disposable income of individuals, inflation-adjusted. Series begins 1977.

Others argue that low interest rates alone cannot wholly account for the trends; indeed a number of facts do not fit that story (Duca et al., 2021a; Panigrahi \& Walker, 2020). House prices have grown far more in the UK than in most comparable countries, for instance, ${ }^{39}$ and this growth has also varied starkly across regions. There are factors specific to London that have driven prices particularly high there, including its perceived status as a safe haven for overseas investors, who moreover are not required to disclose their identity (Badarinza \& Ramadorai, 2018).$^{40}$ However this too fits an emphasis on demand.

\footnotetext{
38 The interest rate represents the income that can be produced by simply buying government bonds. As such, it represents a point of comparison for any other asset. To lightly adapt the example of Wren-Lewis (2020) (and set aside the fact that owning property carries some risk), suppose that a $£ 1,000,000$ house produces $£ 20,000$ of rental income for its owner each year - a $2 \%$ rate of return - and suppose that you can also buy government bonds with the same rate of return. In other words, the prevailing interest rate is $2 \%$, and investing in property is no more attractive than this alternative. Imagine the interest rate then falls to $1 \%$, while rents stay the same. Now $£ 1,000,000$ will produce $£ 20,000$ per year if you invest in housing, but only $£ 10,000$ if you invest in bonds. Those with assets or access to credit (itself stoked by low interest rates) will all prefer to invest in housing, driving the price up until we are back at a point where housing is no more or less attractive than bonds. Rents have stayed the same - our house still produces the same amount of rental income - but now that same $£ 20,000$ per year of rental income makes the house worth $£ 2,000,000$.

39 'Among the G7 countries, the UK has had the largest rise in house prices relative to average disposable income since 1970, and particularly pronounced since 1997' (Muellbauer, 2018: R20).

${ }^{40}$ According to an extended report by investigative journalists from Private Eye magazine, 'For oligarchs, arms dealers, money launderers, kleptocrats and run-of-the-mill tax dodgers, British property is the investment of choice' (Brooks \& Eriksson, 2016: 2). Conservative think tank The Bow Group similarly warn that 'UK citizens face a future as tenants to foreign landlords as an unending supply of money from the wealthy of Russia, China and the Middle East spreads out from London to affect many other parts of the UK' (Valentine, 2015: 55), also
} 
The other side of the debate emphasises constraints on the supply of housing: were people free to respond to these massive price increases by building more houses, prices would fall substantially (Cribb \& Simpson, 2018; Muellbauer, 2018). The counterargument from the demand-side view is that house prices appear to change very little in response to increased supply; ramping up housebuilding will not make - nor would have made - a substantial difference to house prices. Meeting the government's current target of 300,000 new builds per year (a rate not seen since the late 1960s) and sustaining it for 20 years would, all else equal, reduce house prices by only $6 \%$ in real terms, at least according to one estimate (Mulheirn, 2018b). However supply-side advocates in turn can reply that this simply underlines the sheer scale and decades-long persistence of the supply problem. Some evidence suggests that the enormous price increases in London can be accounted for by its particularly constrained supply (Hilber \& Mense, 2021). Indeed a comprehensive recent review of the economic literature highlighted the particular importance of housing supply response as well as shifts in credit conditions (Duca et al., 2021a, 2021b).

The current pattern of increasing property values appears unlikely to continue at the same high rate and may not continue at all, with (as we shall see below) rents flat, interest rates close to zero, the possibility that much investment is driven by a belief that recent gains will continue, and the ease with which this and other beliefs and attitudes can change - including the foreign investor view that UK property represents a 'safe haven', and the not-inevitable UK taste for homeownership over renting.

\section{...and the price of housing}

So house prices are high, but the reasons are not entirely clear and most likely reflect a mix of demandand supply-side factors. To return to the distinction made earlier, what about the price of housing services? Let us set aside for the moment the question of whether it is 'better' in any sense to rent or to buy, and thus whether difficulty buying is a problem in itself. Of primary interest is what is happening to the affordability of having a roof over your head, regardless of whether you own that roof. As first steps in answering this question, in Figures 4.2 and 4.3 I replicate some evidence from Mulheirn (2017a, 2018a). These figures can each be thought of as asking the question: is there any evidence of a shortage of housing services?

Figure 4.2 shows how many more dwellings there are than households in the UK: nearly 1.5 million. ${ }^{41}$ While of course some dwellings are far more desirable than others, and both dwellings and households vary in size and other attributes, this simplified comparison at least gives no indication of an overall strain on housing supply. A steady increase in this surplus has occurred across the same timespan as large house price increases.

Figure 4.3 shows how house prices, household incomes, and rents have all changed in real terms since 1996. ${ }^{42}$ A crisis of housing supply should have seen private rents and house prices both grow similarly,

noting that 'Corruption is rife in many of the countries that invest in the UK' (Valentine, 2015: 23). The UK government has promised 'a register of the beneficial owners of overseas companies owning UK property' (BEIS, 2018: 2), but this has not so far appeared. A House of Commons Library briefing paper (Wilson \& Barton, 2017) offers more information on foreign investment in UK residential property.

41 'Dwellings' essentially means units of accommodation. 'Households' refers to either people living alone or a group of people (not necessarily related) living at the same address who share cooking facilities and a living room or dining area.

${ }^{42}$ This series on rents on the same property over time should not be read as contradicting Figure 4.5 below, which accounts for the fact that many properties have moved from owner-occupancy to the private rented sector, and takes into account household incomes, thereby painting a fuller picture of affordability. 
but rents on the same property over time have only matched inflation, and in fact fallen relative to median incomes.

Figure 4.2 UK housing surplus (dwellings minus households, millions).

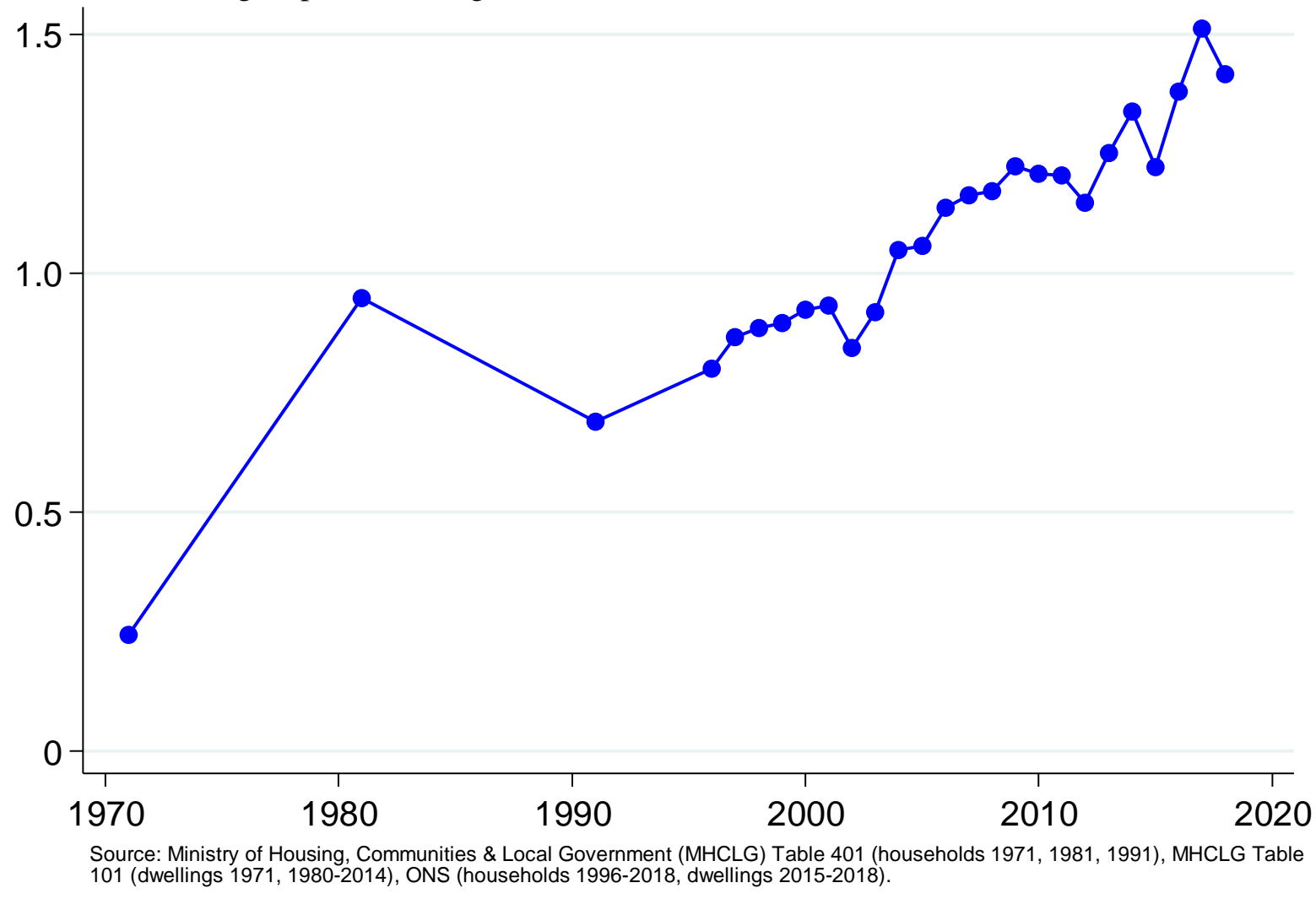

Figure 4.3 UK house prices, median household incomes, and private rents (1996=100), inflationadjusted.

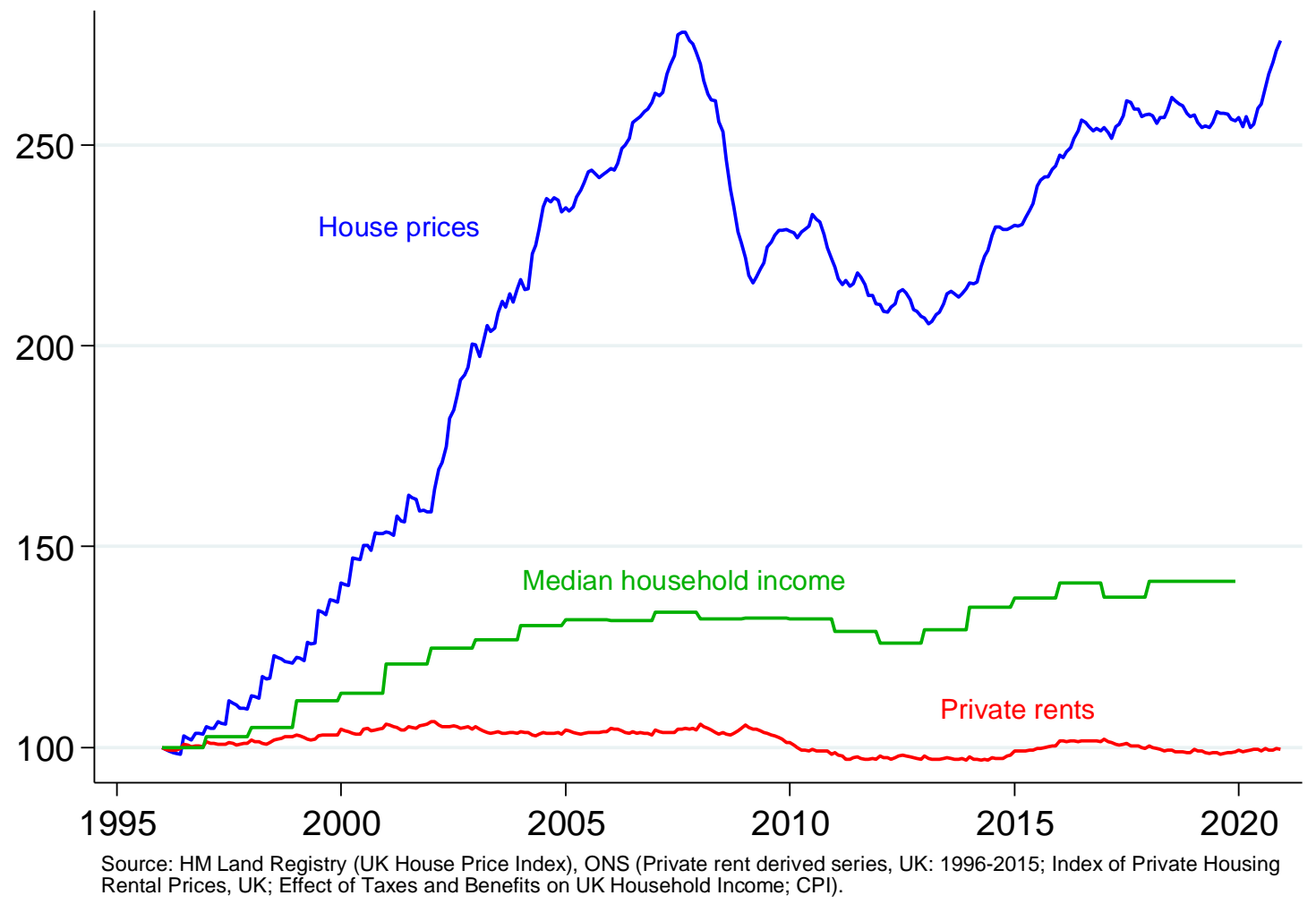


There are important nuances to this overall picture. I have not taken into account the geographical distribution of houses and households. There are undeniably areas with high demand and constrained supply of housing services. ${ }^{43}$ Second, the affordability of housing can affect the rate of new household formation. Households may contain adults who want to move out and form a new, separate household, but cannot afford to do so - for instance a cohabiting couple with a young child living with one partner's parents. ${ }^{44}$

In sum, there is not obviously an overall shortage of housing services - but there has been a far greater demand for housing as an asset than supply has been able to keep pace with. However this overall picture doesn't tell us much about the housing pressures facing young people, not to mention those on low incomes. I now turn to these problems.

\section{The housing trilemma for young people}

So if rents at least have been stable and median incomes growing at least over the longer term, where is the problem? Why is 'a home with security of tenure ... either unaffordable or unavailable' for many young people, as I wrote above? This statement alludes to what is on offer from each of the three main housing sectors: owner-occupancy, private renting, and social renting (i.e. housing provided at belowmarket rents by local government or a housing association). Table 4.1 gives a stylised overview of the situation facing large numbers of young people today, which can be characterised as a trilemma.

Table 4.1 The housing trilemma facing young people.

\begin{tabular}{l|l|l|l} 
& Available? & Secure tenure? & Affordable? \\
\hline Owner-occupancy & $\checkmark$ & $\checkmark$ & $Q$ \\
Private renting & $\checkmark$ & $Q$ & for some \\
Social renting & $Q$ & $\checkmark$ & $\checkmark$
\end{tabular}

Owner-occupancy, or homeownership, offers relative security of tenure. There are houses for sale, but at a very high cost relative to most young people's means. The Resolution Foundation recently estimated that the age at which a typical first-time buyer has saved enough for a deposit rose from 22 for those born in 1974 to 33 for those born in 1985, and projected that this will rise further (Judge \& Leslie, 2021). The time it takes for a low to middle income household to save for a deposit has risen from under five years through the 1980s and 90s to 20 years in 2016 (Corlett \& Clarke, 2017). House price to earnings ratios have shifted to a stably higher level than that observed for most of the 19702000 period (Figure 4.4), and this must also be seen in the context of - as we saw in the previous chapter - younger generations earning less relative to overall average earnings than older generations did at the same age.

Whether homeownership is realistic is also highly - and increasingly - contingent on whether one's parents are homeowners. In the 1990s, 30-year-olds whose parents had some property wealth were just over twice as likely to have become homeowners themselves as those whose parents did not; in the

\footnotetext{
${ }^{43}$ However, at a regional level, only the East Midlands (marginally) saw a larger percentage increase in households than in dwellings over the period from 2001 to 2017 (Mulheirn, 2018a).

44 There is a considerable (but, of course, debated) number of such 'concealed' households. Responses to the 2014-15 English Housing Survey imply 1.5 million households containing one or more adults who would like to buy or rent their own home but cannot afford to (DCLG, 2016). However, it is tricky to measure concealed households. Over a third of those 1.5 million represent non-dependent children aged 16-24. Most would (probably) not consider it a 'crisis' situation to have teenagers or even twenty-somethings living with their parents while they save some money - if there is a realistic prospect of finding somewhere within a reasonable time frame.
} 
2000s and 2010s this had strengthened to three times as likely, with only $8 \%$ of 30 -year-olds whose parents held no property wealth able to get themselves on the housing ladder (Wood \& Clarke, 2018).

Figure 4.4 House price to gross annual earnings ratios (various).

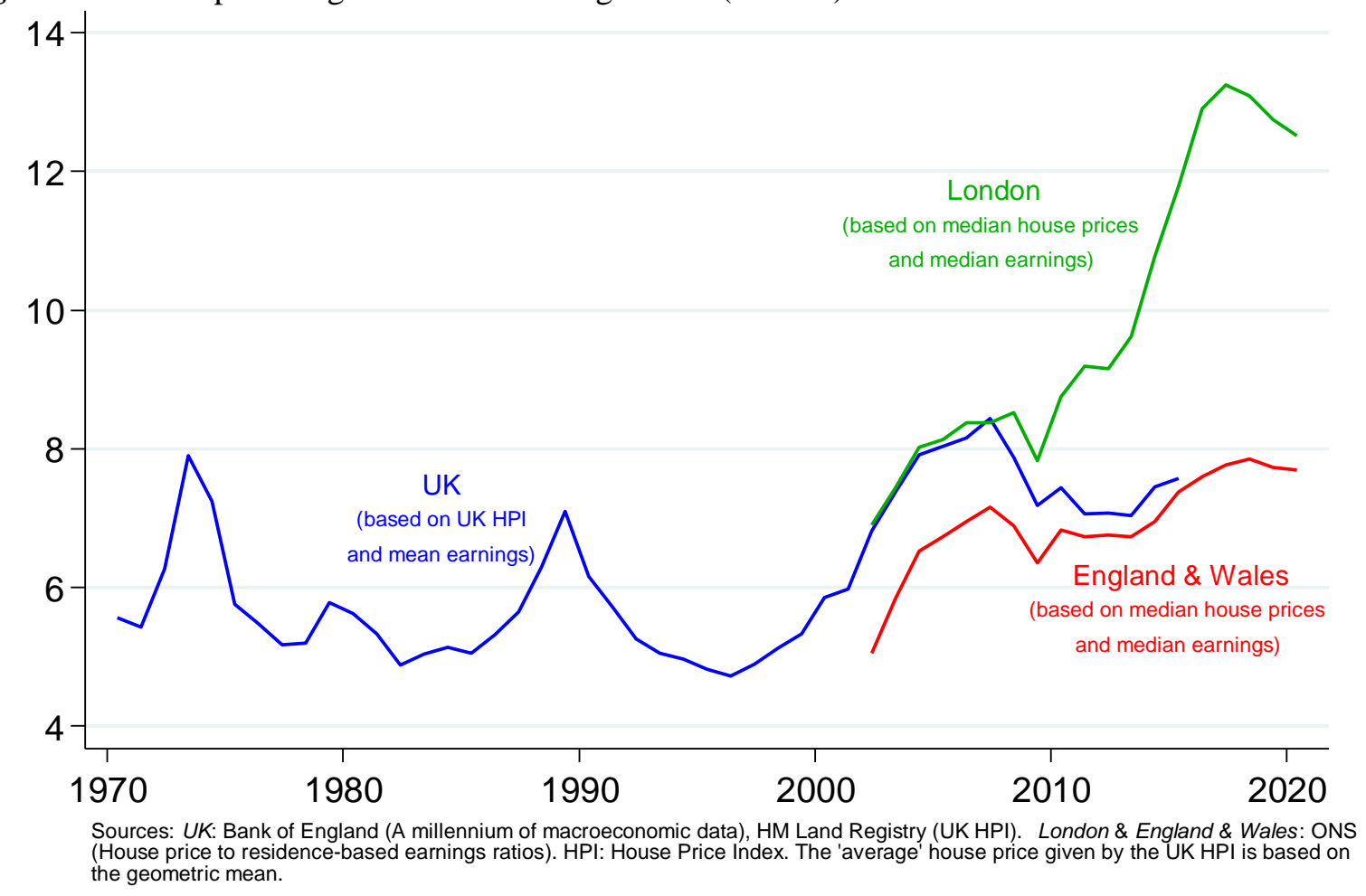

Figure 4.5 Percentage of family income spent on housing costs, by tenure.

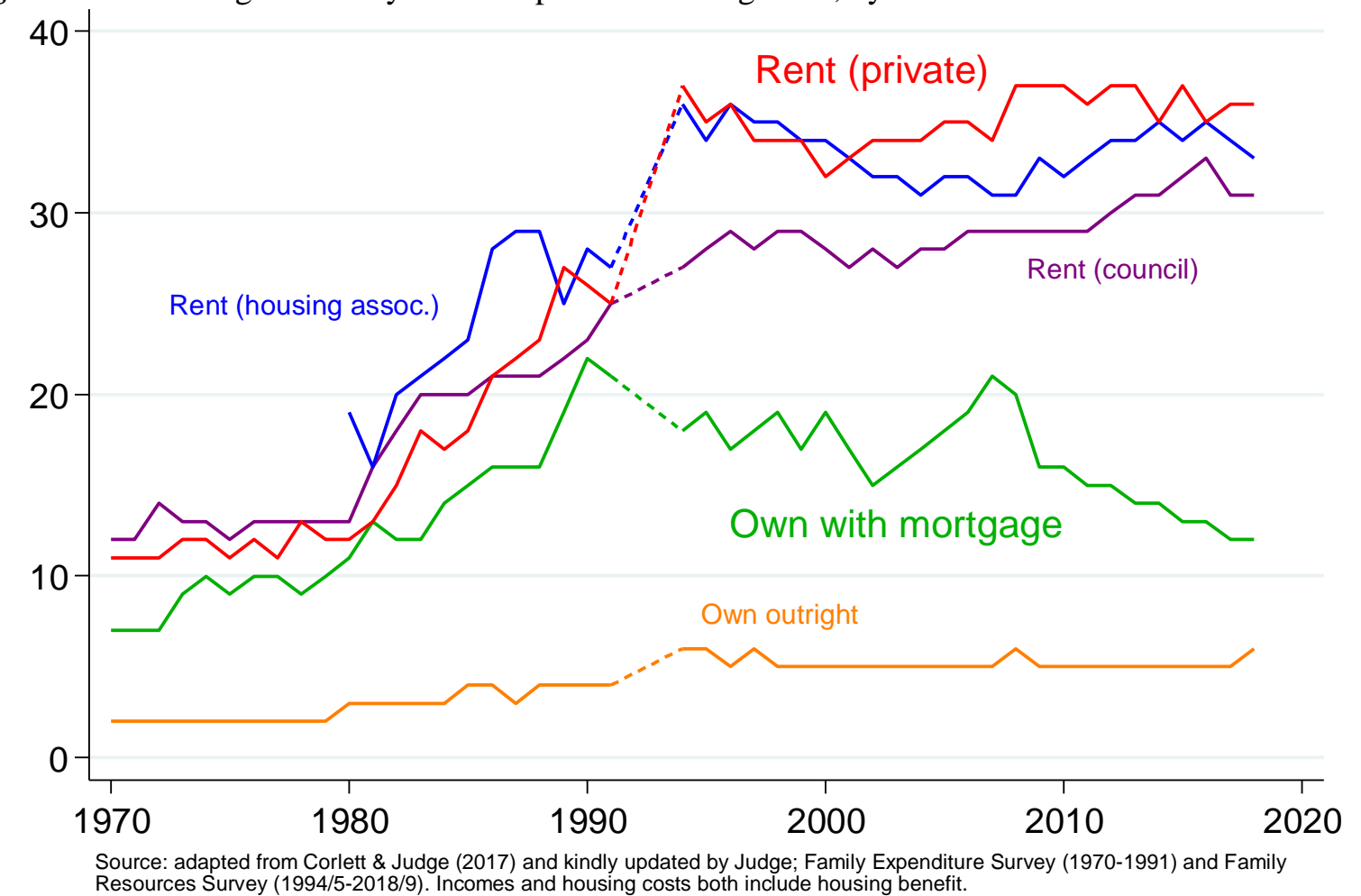


Private renting too is generally available, albeit unaffordable for many. The fact that rents do not appear to have risen much since 1996 must be set aside the fact that they nonetheless consume a large portion of many households' incomes. Figure 4.5, kindly shared by Lindsay Judge of the Resolution Foundation, suggests that while rents may indeed have been stable since the mid-1990s, the preceding decade or so saw very large increases, at least as a proportion of family incomes. One can contend that rents are stable, but stably high, at 35\% or more of net household incomes on average each year from 2005 onwards. The large portion of household budgets going towards rent may be further contributing to the suppressed demand cited as a cause of low productivity.

'Affordability' is a bit subjective, and measures of rent as a proportion of income do not necessarily imply anything about how well households are coping financially. By way of rough guidance however, 'affordable' is equated with $33 \%$ of net household income by Shelter, $25 \%$ by the National Housing Federation, and $30 \%$ by the Department of Housing in the US (Barr \& Malik, 2016). Above this, especially for families with lower incomes, cuts must be found to other basics such as food, heating, and transport.

One manifestation of the strain exerted on families by high private rents is an increasing level of overcrowding, as shown in Figure 4.6. Overcrowding among private-rented households has approximately doubled over the past 25 years (and increased sharply too in the social sector). The absolute percentage may appear low: 6.7\% of private-rented households were overcrowded in 2019 according to the 'bedroom standard' measure used here (see p.75 for a definition). But it is important to recognise that by modern standards this measure sets a very high bar for what counts as overcrowded, and makes no reference to floor area or rooms other than bedrooms. For example, a household would not be counted as overcrowded, no matter its floor area, if it consisted of two parents sharing one bedroom and two brothers aged 12 and 16 sharing a second bedroom. This 'bedroom standard' measure is the most reliable and comparable across time that we have, but the way to read this figure is to look at the direction and size of the change over time, not the apparently low level of overcrowding.

Figure 4.6 Overcrowding, by tenure (\% of households).

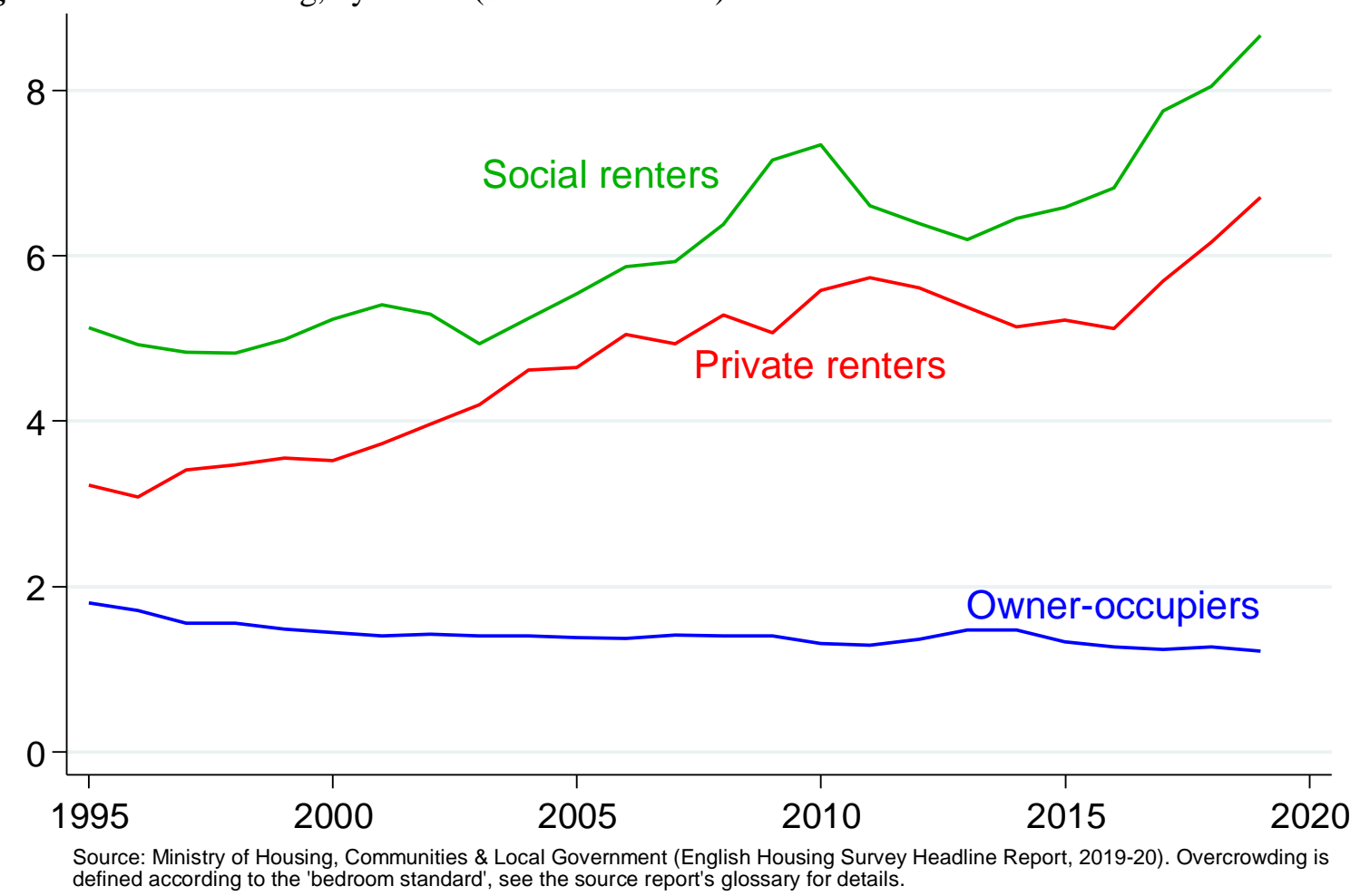


It is also crucial to consider the experience of private renting, independent of its affordability. Among other concerns, tenants are offered little security of tenure under the usual type of rental agreement, an assured shorthold tenancy. Depending on the circumstances, they may be ordered to leave with two months' notice. More usually, these tenancies offer six or twelve months of tenure at a time. There is no necessary reason for such short tenancies. As Muellbauer writes: 'The average duration of rental contracts [in the UK] is 2.5 years, though less in London. By contrast, the German contracts underpin indefinite tenancies and the average duration of rental contracts is eleven years' (2018: R24).

One might imagine such short-term agreements suiting the lifestyle of a dynamic single young worker, but it must be borne in mind that private renting is the only option for increasing numbers of families with children (or who want to have children), who are likely to value stability and the sense of belonging to a community. In 1994, $6 \%$ of children lived in private rented accommodation. By 2017 , this had risen to $22 \%$ (Bailey, 2020).

A final downside to private renting - again particularly notable in the context of growing numbers of children living in such accommodation - is the quality of the housing stock in this sector. The government uses a summary measure of whether a home is 'decent' that takes into account issues such as its safety, state of repair, and quality of basic facilities. On this measure, the private rented sector has seen considerable progress since (at least) 2009. But it remains the case that nearly one-in-four dwellings in the private rented sector do not meet this minimum standard - a far higher proportion than the owner-occupied and social-rented sectors.

As for social renting, this sector tends to offer better security and affordable rents, but the stock of socially rented housing has fallen substantially, as shown in Figure 4.8. Accordingly it is widely unavailable to young people, and increasing numbers are instead paying market rents.

Figure 4.7 Dwellings classified 'non-decent', by tenure (\%).

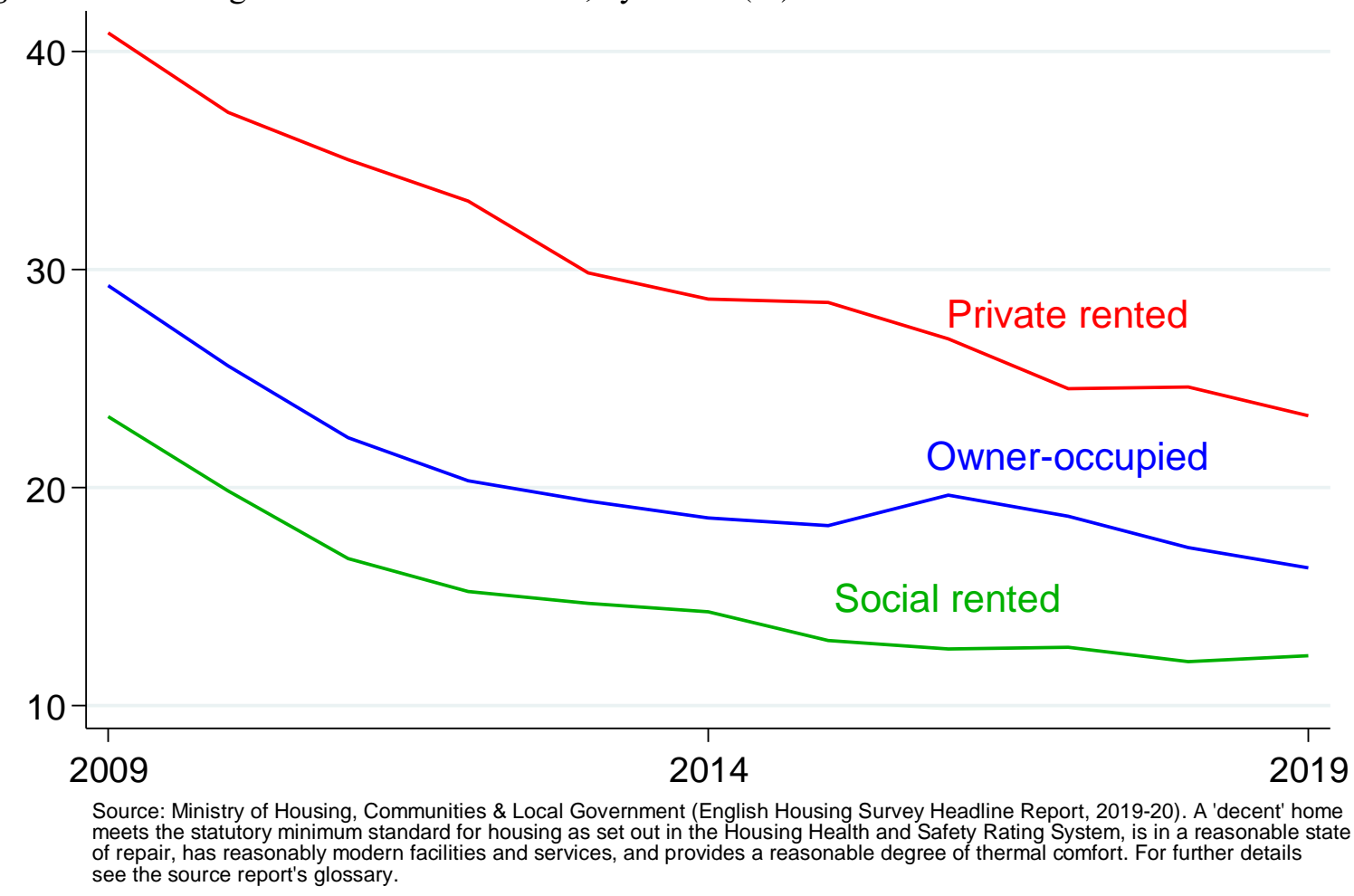


Figure 4.8 Housing tenure (\% of households).

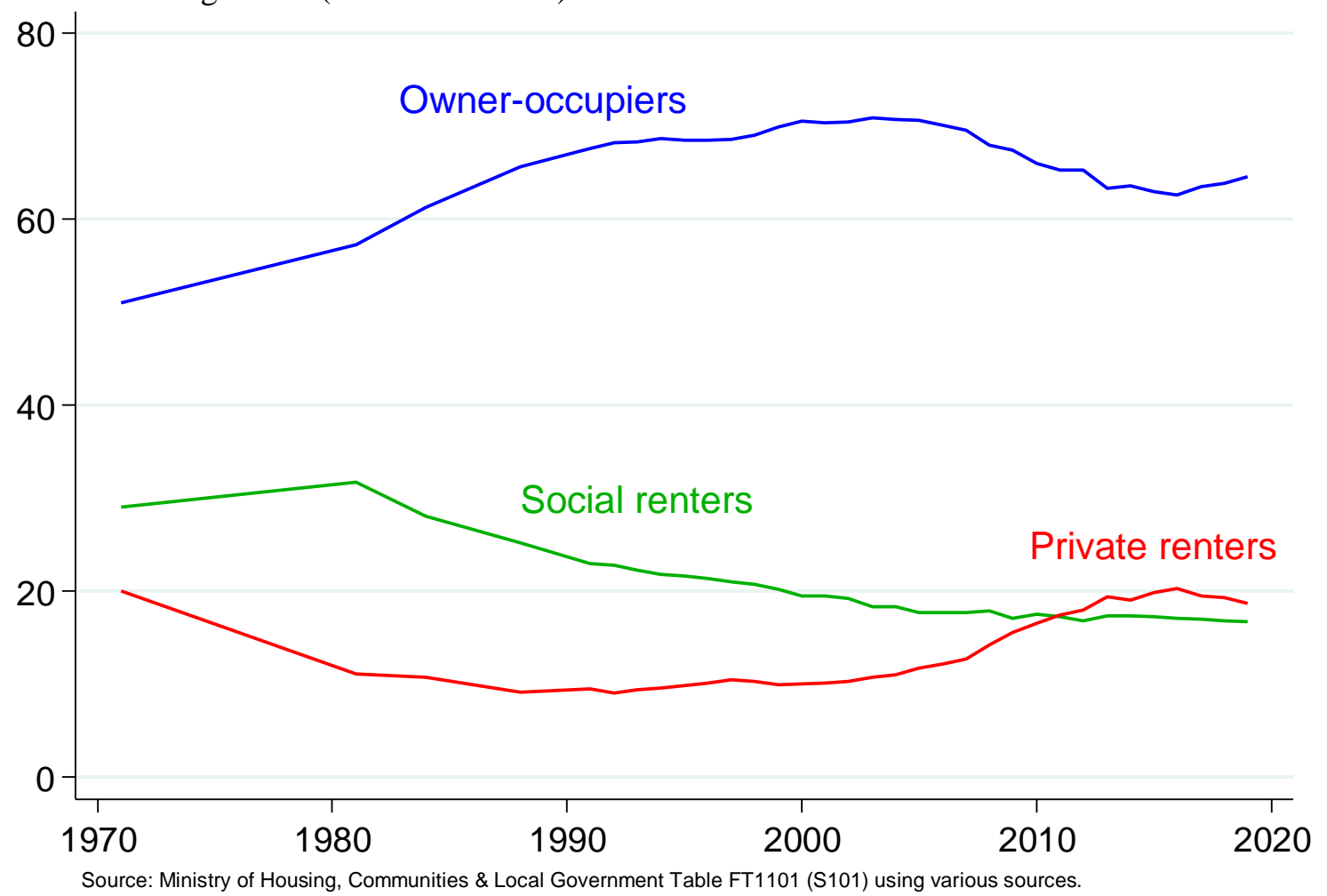

\section{The impact on younger generations}

What has this all meant for each generation? The unsurprising consequence of much higher house prices is that younger generations are far less likely to have a foot on the housing ladder at a given age. Figure 4.9 shows the level of homeownership (with or without a mortgage) at each age according to year of birth (grouped into five-year birth cohorts). At age 30, 40\% of the 'mid-Millennial' generation (born 1986-1990) were owner-occupiers, compared with 64\% for each of the Baby Boomer cohorts born $1951-1965 .^{45}$

Figures 4.10 and 4.11 show the percentages of individuals living in the social rented and private rented sectors respectively. This illustrates a profound change across the generations. In early adulthood, many more Baby Boomers than Generation X or Millennials lived in the social rented sector. By contrast, private renting is far more prevalent for Millennials than the two older generations. Of that midMillennial 1986-1990 cohort, $11 \%$ lived in the social rented sector and $37 \%$ in the private rented sector at age 30. The equivalent numbers for those born 1956-1960 are 19\% and 7\%.

What about those not included in the previous figures because they live with their parents? Figure 4.12 shows this percentage across the generations. There is again a pronounced change. There is a relatively stable pattern of about $60 \%$ living in the parental home at age 20 , falling to about $10 \%$ at age 30 . But younger generations appear to be leaving later, and possibly returning (or 'boomeranging') at higher rates. $17 \%$ of those born 1951-1955 lived at home at age 25, rising to 35\% of those born 1991-1995.

\footnotetext{
${ }^{45}$ Judge and Leslie give a closely related estimate, in terms of the percentage of family units (which might include single individuals, or couples with or without children) rather than individuals (and referring to the age and cohort of the 'head' of the family unit): ' $55 \%$ of those born between 1956-1960 were homeowners by the age of $30 \ldots$ compared to just $27 \%$ for those born $1981-1985$ ' (2021: 5).
} 
Figure 4.9 Homeownership, by age and birth cohort (\%).

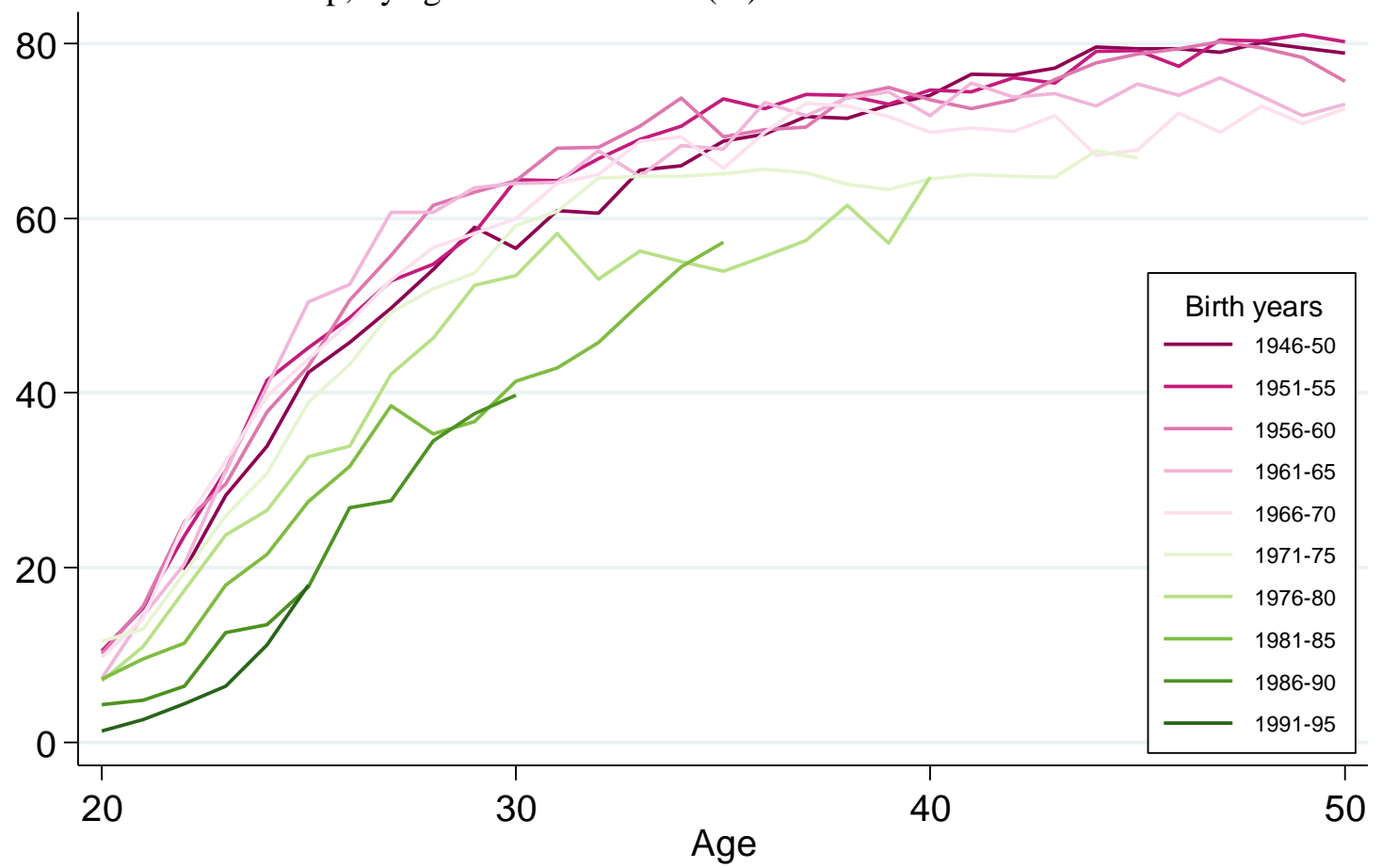

Source: Family Expenditure Survey 1968-2001, Living Costs and Food Survey 2002-2020. Institute for Fiscal Studies Derived Variables Dataset, updated with most recent data.

Figure 4.10 Social renting, by age and birth cohort (\%).

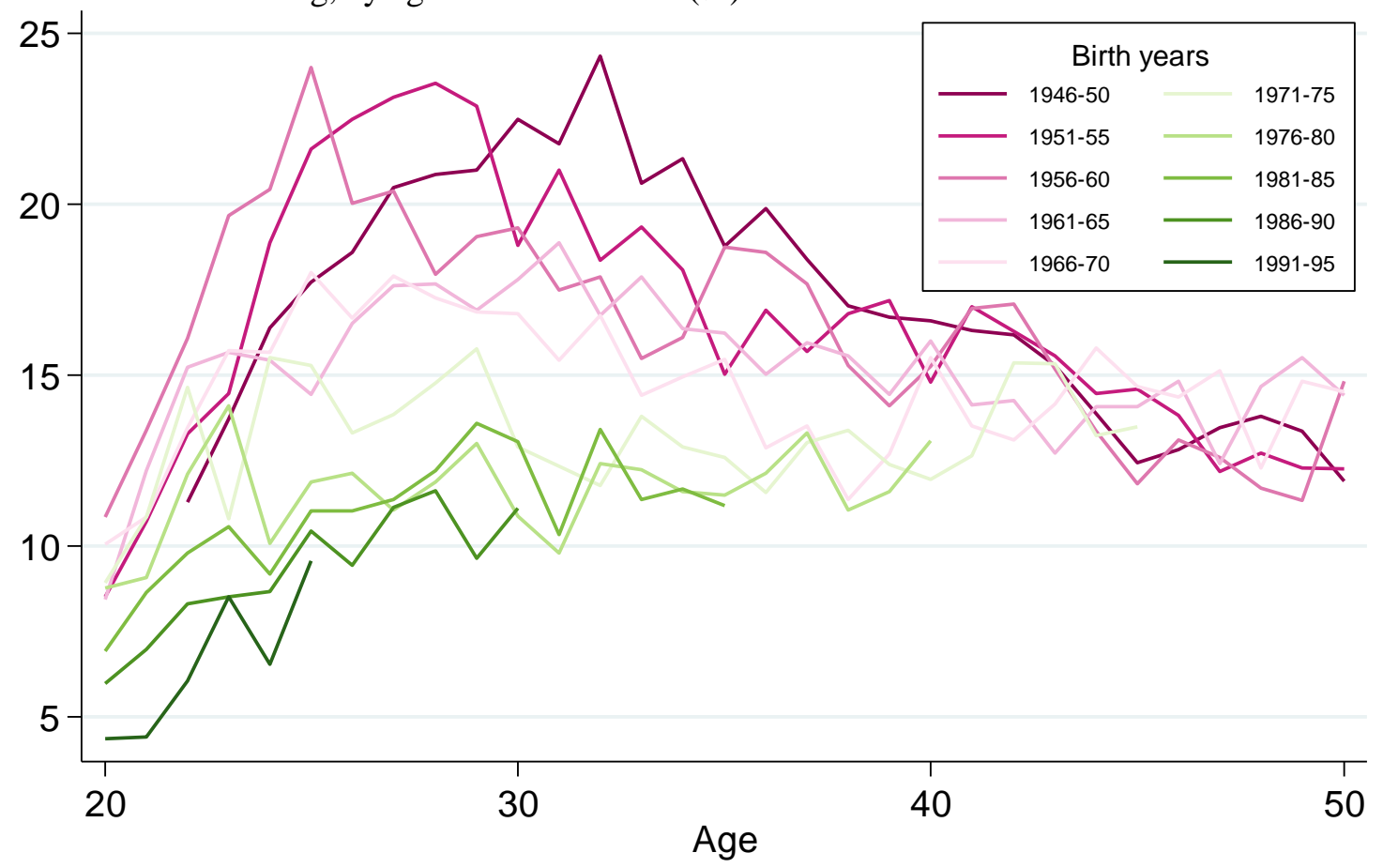

Source: Family Expenditure Survey 1968-2001, Living Costs and Food Survey 2002-2020. Institute for Fiscal Studies Derived Variables Dataset, updated with most recent data. 
Figure 4.11 Private renting, by age and birth cohort (\%).

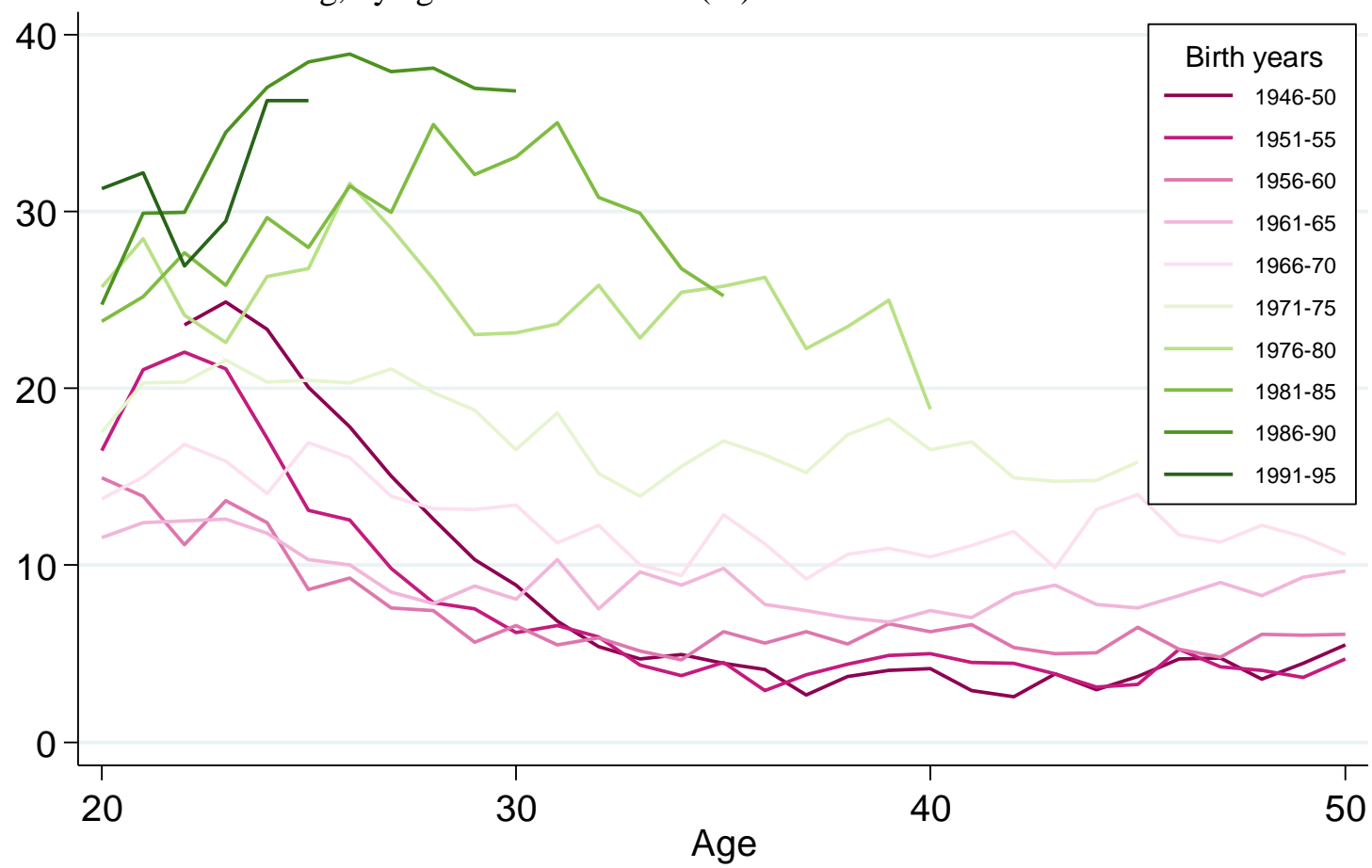

Source: Family Expenditure Survey 1968-2001, Living Costs and Food Survey 2002-2020. Institute for Fiscal Studies Derived Variables Dataset, updated with most recent data.

Figure 4.12 Living with parents, by age and birth cohort (\%).

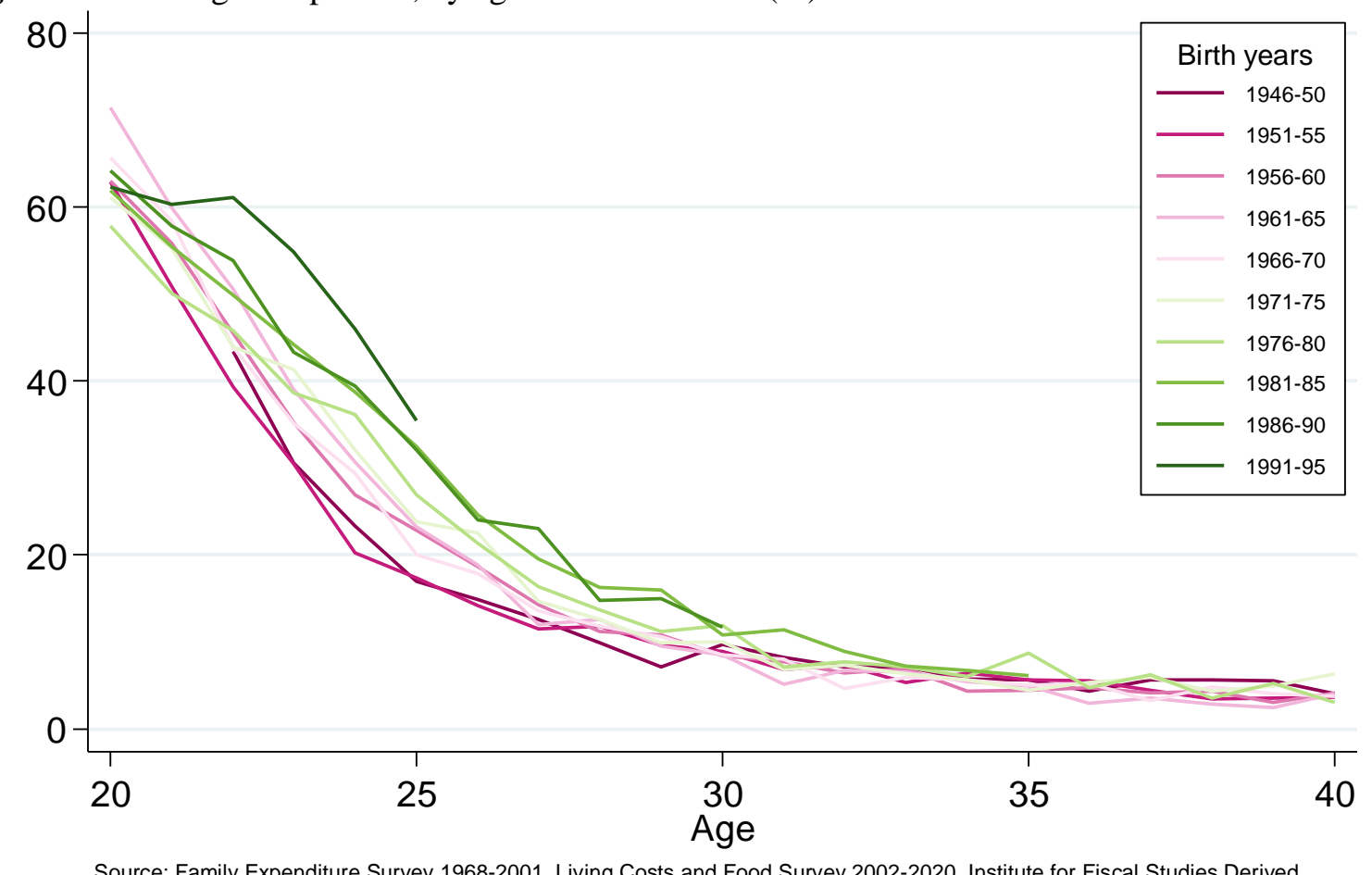

Source: Family Expenditure Survey 1968-2001, Living Costs and Food Survey 2002-2020. Institute for Fiscal Studies Derived Variables Dataset, updated with most recent data. Includes individuals living with parent(s)-in-law or with grandparent(s). 
Younger generations are thus less likely to own a home or be able to access social housing. They are more likely to be living with their parents, and much more likely to be living in insecure and relatively expensive private rented accommodation - increasingly, as we have seen, with their young children, though they are having children at lower rates than previous generations.

What does this mean for households' financial wellbeing? Figure 4.13 shows the percentage of family income spent on housing costs by age and generation. Housing is taking a much larger slice of household budgets for younger generations compared to older, particularly when we compare Millennials and Generation X to Baby Boomers at around age 30. This is driven both by increasing numbers renting privately, and by the long-term increase in private rents as a proportion of family incomes shown above in Figure 4.5, exacerbated by the slow growth in young people's earnings for recent generations. As Figure 4.14 shows, private renting itself has become more expensive relative to incomes, taking about a third of household income for Millennials in their 20s and Generation X in their $20 \mathrm{~s}$ and 30s - compared with about a fifth for those Baby Boomers who lived in private rented accommodation in their $20 \mathrm{~s}^{46}$

Figure 4.13 Percentage of family income spent on housing costs, by age and generation.

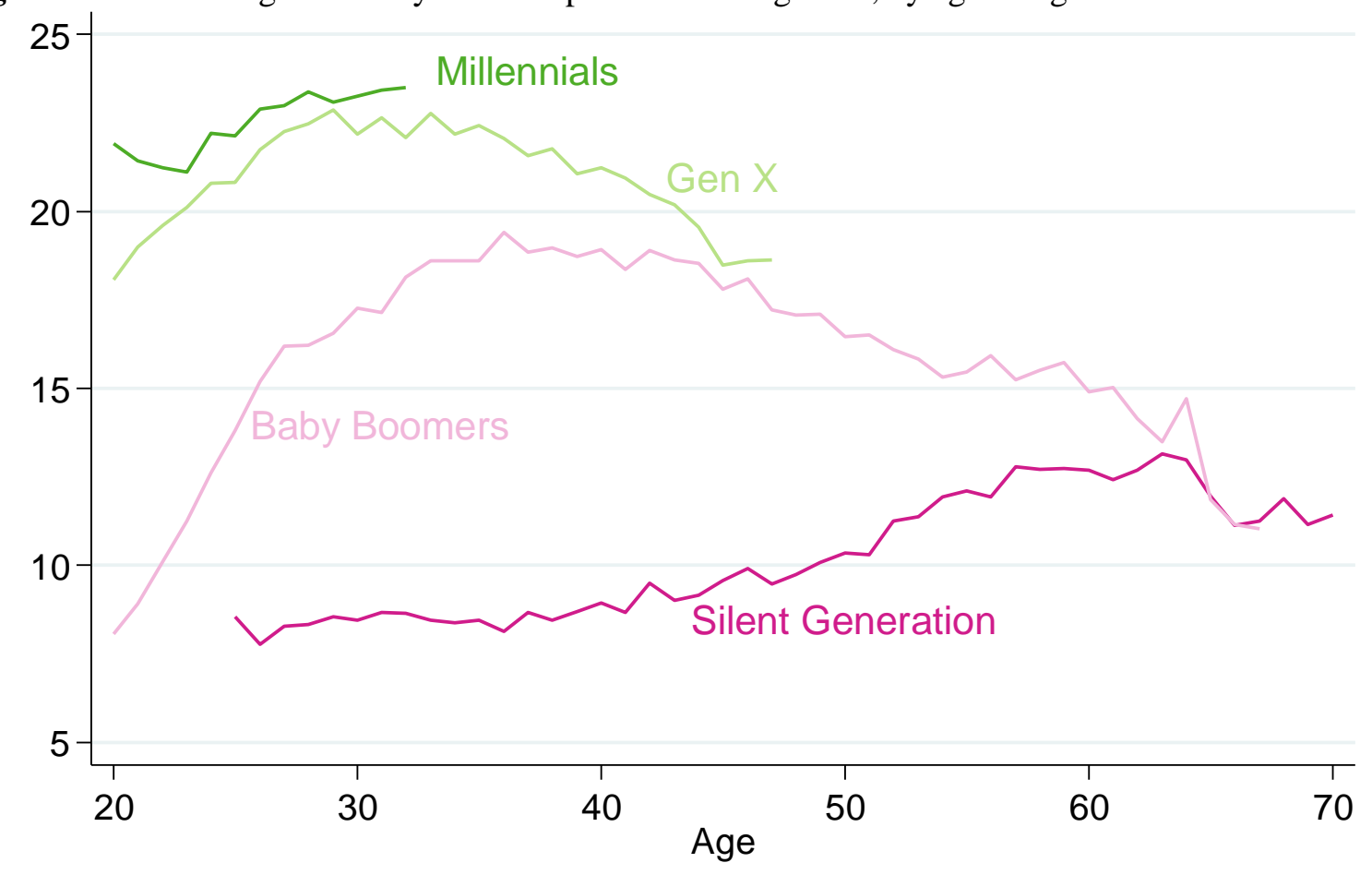

Source: adapted from Corlett \& Judge (2017) and kindly updated by Judge; Family Expenditure Survey (1970-1991) and Family Resources Survey (1994/5-2018/9). Incomes and housing costs both include housing benefit.

\footnotetext{
${ }^{46}$ Figures 4.5, 4.13, and 4.14 reproduce Figures 19, 20, and 24 from the Resolution Foundation's Home Affront: Housing across the generations (Corlett \& Judge, 2017), kindly updated with the most recent data by Judge.
} 
Figure 4.14 Percentage of family income spent on housing costs (private renters only), by age and generation.

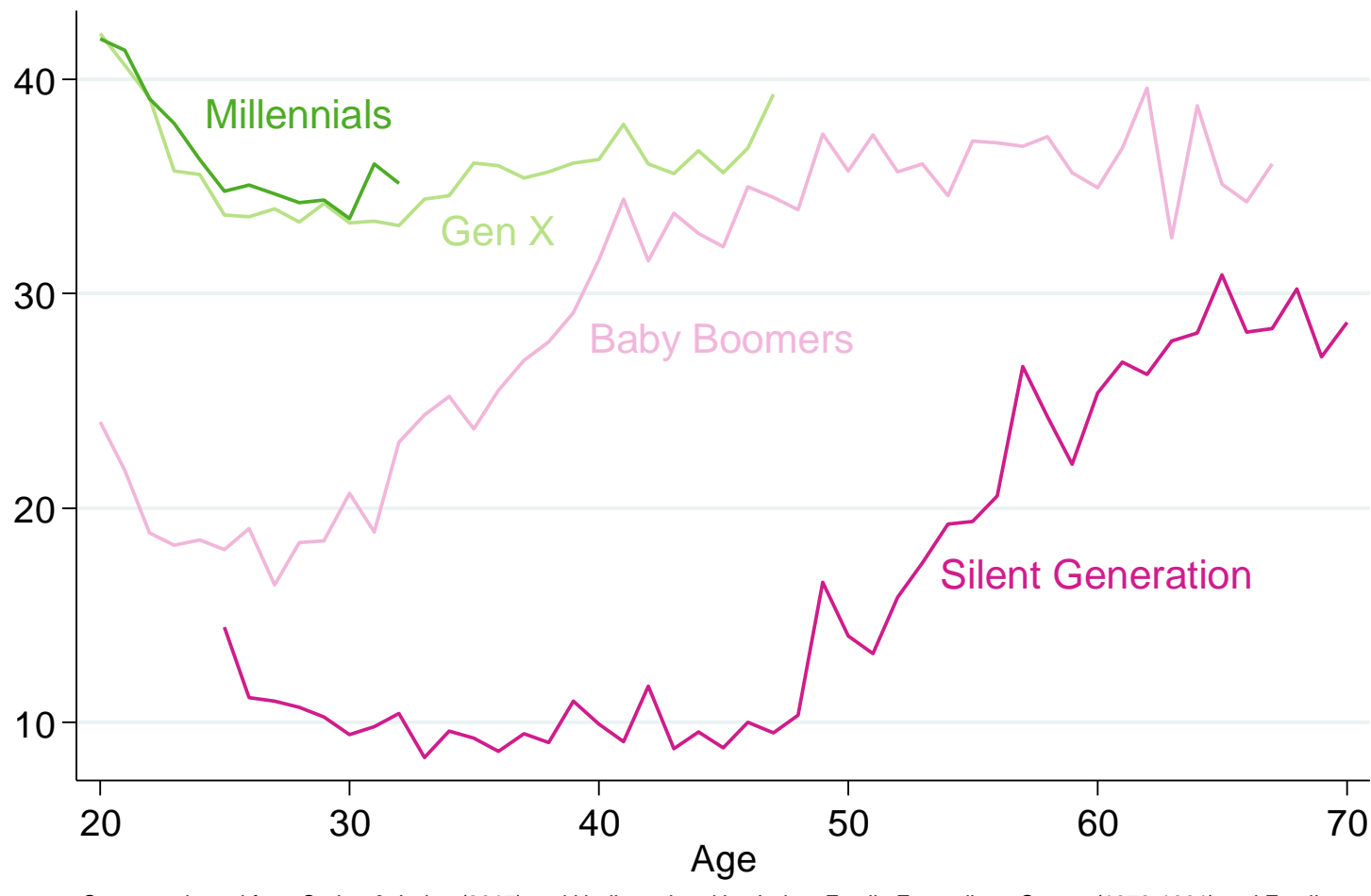

Source: adapted from Corlett \& Judge (2017) and kindly updated by Judge; Family Expenditure Survey (1970-1991) and Family Resources Survey (1994/5-2018/9). Incomes and housing costs both include housing benefit.

\section{From housing to wealth: the impact on older generations}

The fact that younger generations are increasingly living in the private rented sector has important implications for the distribution of wealth across the generations. They are mostly paying this rent to members of older generations (Bangham, 2019) ${ }^{47}$ This contrasts with the experience of those older generations themselves, who effectively paid much of their housing expenditure at these ages to themselves through owner-occupancy with a mortgage. ${ }^{48}$

Many of this generation were also beneficiaries of Right to Buy legislation introduced in the 1980 Housing Act, which involved the selling off of local government housing to tenants at discounts of up to 50\% of market value (Muellbauer, 2018). 2.2 million units of social housing have been sold under

\footnotetext{
${ }^{47}$ Moreover, state subsidy for housing services has been increasingly directed to private landlords through housing benefit - paid to $20 \%$ of private tenants in 2019-2020 (MHCLG, 2020) - rather than to low-income tenants through provision of social housing.

${ }^{48}$ Theoretically, the costs of homeowning and renting (at market rates) are the same (Mulheirn, 2017b), at least on average over time. Homeowners have costs that renters do not, including maintenance, depreciation, and mortgage interest payments. Further, homeowners in fact pay rent just like renters, in the sense that by living in their house, they lose the opportunity to rent it out and gain income from their asset. It follows that young renters are not disadvantaged in their wealth accumulation by renting, since money they don't have to spend on things like maintenance and mortgage interest can instead be saved. If this sounds counterintuitive, it is because there is indeed an important departure from reality involved: banks do not give young renters hundreds of thousands of pounds to invest in any asset other than housing. At the same time, while private renters are free to diligently build up their savings but might not manage to stick to it, mortgage-holders are essentially compelled to save, by repaying their mortgage.
} 
Right to Buy and related schemes, mostly in the 1980s and early 2000s (DLUHC \& MHCLG, 2022b) ${ }^{49}$ Over $40 \%$ of these properties are now being rented out privately, according to an investigation by Inside Housing (Barker, 2017).

Figures 4.1 and 4.9 showing house price increases and homeownership rates together give an indication of what housing trends have ultimately resulted in for the Baby Boomer generation: a very large windfall (see Figure 5.1 below). Having bought houses in the 1970s, 80s, and 90s, those who made it through the turbulence of various interest rate spikes saw substantial capital gains on those houses as prices rose. According to Resolution Foundation modelling, $60 \%$ of the housing wealth held by the typical first-time buyer born between 1951 and 1955 at the end of their mortgage term resulted from such 'passive' gains, in contrast with a projected 36\% for the 1986-1990 cohort (Judge \& Leslie, 2021).

\section{Investment in property}

Fuelled in part by capital gains on their main homes, a substantial number of Baby Boomers have chosen to invest in additional property. As Table 4.2 shows, 17.6\% of those born between 1948 and 1967 either own some form of property wealth in addition to their main home, or their partner does. ${ }^{50}$ This 'additional property wealth' (hereafter APW) mostly consists of buy-to-lets and second homes, held by $8 \%$ and $6.4 \%$ of this group respectively.

Table 4.2 Percentage of GB residents born 1948-1967 in households owning each type of additional property wealth.

\begin{tabular}{|l|r|}
\hline Buy-to-let & $8.0 \%$ \\
\hline Second home & $6.4 \%$ \\
\hline Other UK buildings / real estate & $1.4 \%$ \\
\hline UK land & $1.4 \%$ \\
\hline Overseas property & $3.1 \%$ \\
\hline Any of the above & $17.6 \%$ \\
\hline
\end{tabular}

Source: ONS Wealth and Assets Survey 2016-2018. Includes individuals whose partner reports owning each asset.

Among other factors, this APW ownership has been incentivised by tax relief for landlords' finance costs and enabled by the introduction in 1996 of buy-to-let mortgages, often on an interest-only basis (Bangham, 2019). Figure 4.15 shows how buy-to-let ownership in particular has surged in recent years. The number of individuals who report owning a buy-to-let property increased from 1.2 million in 200810 to 2.1 million in $2016-18 .^{51}$

Over the same period, the number owning a second home has also grown, from 1 million to 1.3 million. This number is perhaps best sized up alongside those presented in Figure 4.2 above, which showed a housing surplus of approximately 1.4 million dwellings. Deduct those second homes - albeit some may be double-counted if two people jointly own a given property - and the market for housing services appears much tighter.

\footnotetext{
${ }^{49}$ Over the same period (1980-2021), 1.2 million dwellings have been built by housing associations and local authorities (DLUHC \& MHCLG, 2022a).

${ }^{50}$ I have used these birth years which don't neatly align with the usual generational labels simply because the data do not specify age to the year, only within a five-year range.

${ }^{51}$ Whereas Table 4.2 gives the percentage of people who either own each type of property or their partner does, Figure 4.15 counts the number of individuals who report owning each type of property themselves. Note however that two individuals may jointly own a single property, so this is not necessarily a good indicator of the number of, for instance, second homes in the UK. See pages 8-9 of Bangham (2019) for more information on the available data on additional property wealth in the UK, including some in which properties rather than individuals are the units of analysis.
} 
Figure 4.15 Number of GB residents holding each type of additional property wealth (millions).

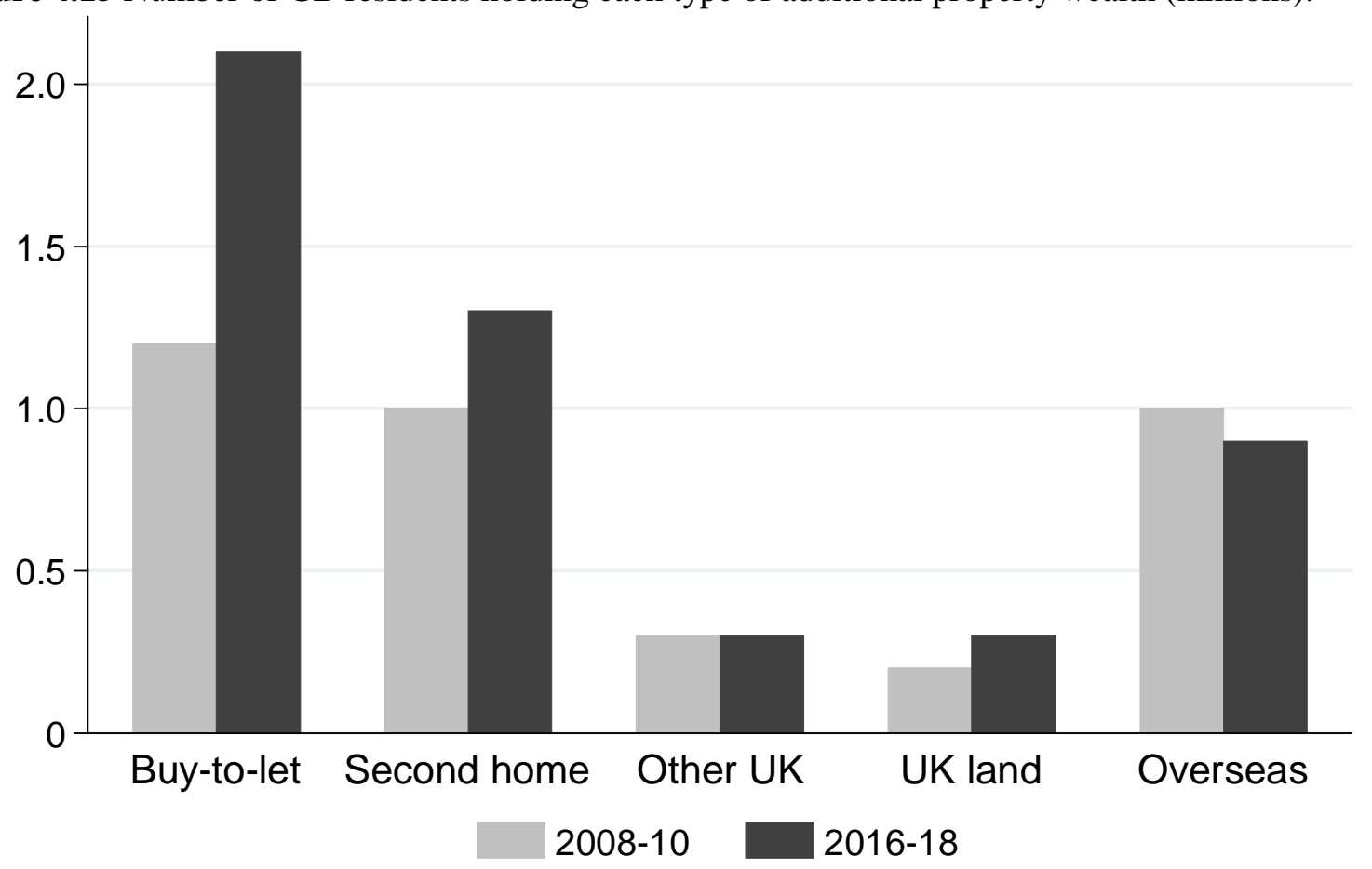

Source: ONS Wealth and Assets Survey. Adapted from Bangham (2019) and updated using the most recent available data. Other UK: other buildings / real estate in UK.

Bangham (2019) discusses the characteristics of those with additional property wealth, and the concentration of this wealth within that group (looking at data from 2014-2016). 17\% of those born in the 1950s live in a family that holds such wealth in one form or another. Holding age constant, 1960s and 1970s cohorts are holding additional property wealth at higher rates and in higher amounts, but those born in the 1980s are falling behind - though we only know how they have fared up to their 30s. Looking beyond the age and birth year of additional property holders, 'second home and buy-to-let ownership is mainly a richer, wealthier phenomenon' (2019: 14), heavily concentrated in the top income and wealth quintiles.

Additional property wealth is also quite extensively dispersed across those who do hold it. Of the individuals with buy-to-let wealth, $68 \%$ reported only owning one buy-to-let property. $10 \%$ reported holding more than three. Second homes were more evenly distributed, with $89 \%$ of second home owners having just one such property. While it may be encouraging in some respects that multiple property ownership is spread across a large number of small-scale landlords, this carries a disadvantage for tenants in the risk that their landlord has no specialisation or particular interest in being a landlord, and if hit by a financial shock or change of preference may decide to end the tenancy at short notice and sell the property. This further contributes to insecurity of tenure.

This section has offered a brief look at the extent of investment in housing beyond that which one uses on an everyday basis. But there is a further, often overlooked, dimension to this trend. The logical equivalent of buying housing you will not use is not selling housing you currently own but are not using. ${ }^{52}$ Though the latter is not a straightforward concept to measure, Figure 4.16 shows rates of underoccupation of housing again based on the 'bedroom standard' discussed above with reference to overcrowding. Under-occupation is defined as having at least two bedrooms more than the number

\footnotetext{
52 This of course also applies to those who do not actively purchase houses in order to let them out, but let out rather than sell houses they have acquired through inheritance.
} 
needed according to the bedroom standard. To better evaluate the numbers here, it is worth having a definition of the bedroom standard (MHCLG, 2020: 50) to hand:

A separate bedroom is allowed for each married or cohabiting couple, any other person aged 21 or over, each pair of adolescents aged 10-20 of the same sex, and each pair of children under 10. Any unpaired person aged 10-20 is notionally paired, if possible, with a child under 10 of the same sex, or, if that is not possible, he or she is counted as requiring a separate bedroom, as is any unpaired child under 10.

So among the 'under-occupied' households will be some larger families in which two parents share a room, each child has their own bedroom, and there are no unoccupied bedrooms - for instance if there are four children comprising two teenage boys (who notionally could share a room) and a boy and a girl under 10 (who also notionally could share a room). There will be more 'under-occupied' households with just one truly 'spare' bedroom. And a considerable number of households will use such 'spare' bedrooms regularly if not constantly - for instance accommodating a carer or a child who normally lives with the other parent. Still other households may have spare rooms in anticipation of new family members. But even taking all these caveats into account, it is quite striking that the majority of owneroccupied properties in England are under-occupied, a proportion that has grown steadily over the past 25 years.

Figure 4.16 Under-occupation, by tenure (\% of households).

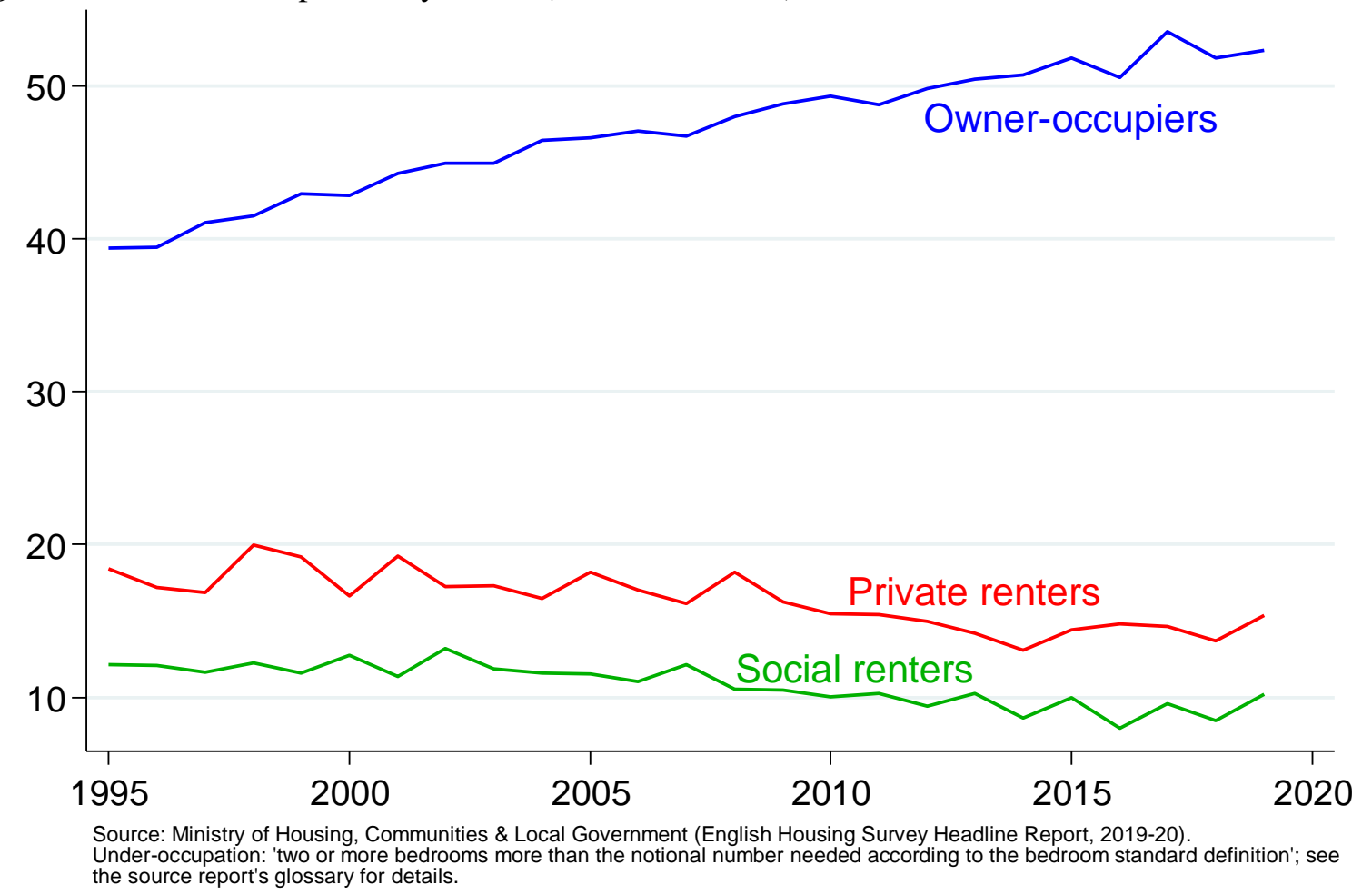




\section{Wealth}

Wealth and particularly property wealth are central to understanding how different generations are faring in the UK today. For this reason I have already discussed wealth in the introduction and in the previous chapter on housing. In this short section I focus on the limited comparison it is possible to make between different cohorts at the same age, but I first briefly discuss property and pension wealth.

No data are available that would let us straightforwardly compare the overall wealth of each generation at, say, age 30, in the way we have been able to do for unemployment or homeownership. However, data on homeownership and pension enrolment give us strong indirect evidence. This is because personal wealth in the UK is heavily concentrated in property and pension entitlements, as reflected in Table 5.1 (Table 1.2 from the introduction).

Table 5.1 Total net wealth of British residents in 2014-16, by birth cohort and asset type. ${ }^{53}$

\begin{tabular}{|r|r|r|r|r|r|r|r|r|}
\hline Born & $\begin{array}{c}\text { Age in } \\
\mathbf{2 0 1 5}\end{array}$ & $\begin{array}{r}\text { Main } \\
\text { property }\end{array}$ & $\begin{array}{c}\text { Additional } \\
\text { property }\end{array}$ & Pension & Financial & Physical & Total \\
\hline & & & & & & \\
\hline $1991-1995$ & $20-24$ & 5 & 4 & 9 & -1 & 60 & 77 \\
\hline $1986-1990$ & $25-29$ & 38 & 15 & 37 & 15 & 64 & 168 \\
\hline $1981-1985$ & $30-34$ & 102 & 34 & 121 & 25 & 94 & 376 \\
\hline $1976-1980$ & $35-39$ & 204 & 36 & 199 & 48 & 92 & 579 \\
\hline $1971-1975$ & $40-44$ & 287 & 49 & 343 & 76 & 114 & 871 \\
\hline $1966-1970$ & $45-49$ & 391 & 81 & 581 & 116 & 124 & 1,293 \\
\hline $1961-1965$ & $50-54$ & 459 & 90 & 837 & 159 & 125 & 1,670 \\
\hline $1956-1960$ & $55-59$ & 482 & 97 & 1,022 & 216 & 119 & 1,937 \\
\hline $1951-1955$ & $60-64$ & 495 & 95 & 969 & 229 & 124 & 1,912 \\
\hline $1946-1950$ & $65-69$ & 547 & 105 & 842 & 255 & 131 & 1,880 \\
\hline $1941-1945$ & $70-74$ & 403 & 100 & 439 & 272 & 99 & 1,312 \\
\hline $1936-1940$ & $75-79$ & 284 & 18 & 227 & 121 & 69 & 718 \\
\hline-1935 & $80-$ & 425 & 19 & 178 & 152 & 94 & 869 \\
\hline
\end{tabular}

Source: ONS Wealth and Assets Survey. Inflated to January 2020 prices. Additional property wealth refers to land and property held in addition to the individual's main residence. Pension wealth refers to private pension wealth and is partly based on ONS estimation of the value of individuals' pension entitlements. Financial wealth refers to formal and informal financial assets, plus the value of certain assets held in the names of children, plus the value of endowments purchased to repay mortgages, less the value of non-mortgage debt. Physical wealth refers to household contents, collectibles and valuables, and vehicles. I have used the 2014-16 data rather than the (latest available) 2016-18 data because age is available only in five-year bands and (reading 2015 for 2014-16) this wave allows a neater correspondence to the birth years traditionally defining the generations.

We have already seen large generational differences in homeownership rates at the same age. Taken in concert with the timing of house price increases, the result has been lower average property wealth for younger cohorts, particularly the 1970s and 1980s cohorts relative to their predecessors. This is illustrated in Figure 5.1, reproduced from Bangham et al. (2019). ${ }^{54}$

\footnotetext{
53 This table is the same as Table 1.2. See also footnote 6 in the introduction.

${ }^{54}$ Bangham et al. (2019) were able to make comparisons of property wealth over a longer time span than is possible with total wealth by extrapolating Wealth and Assets Survey data from 2006-2016 back in time using other, earlier survey data including information on individuals' homeownership. See also D'Arcy \& Gardiner (2017).
} 
Figure 5.1 Mean family net property wealth per adult, by age and birth cohort ( $£$ thousands, 2018-19 prices).

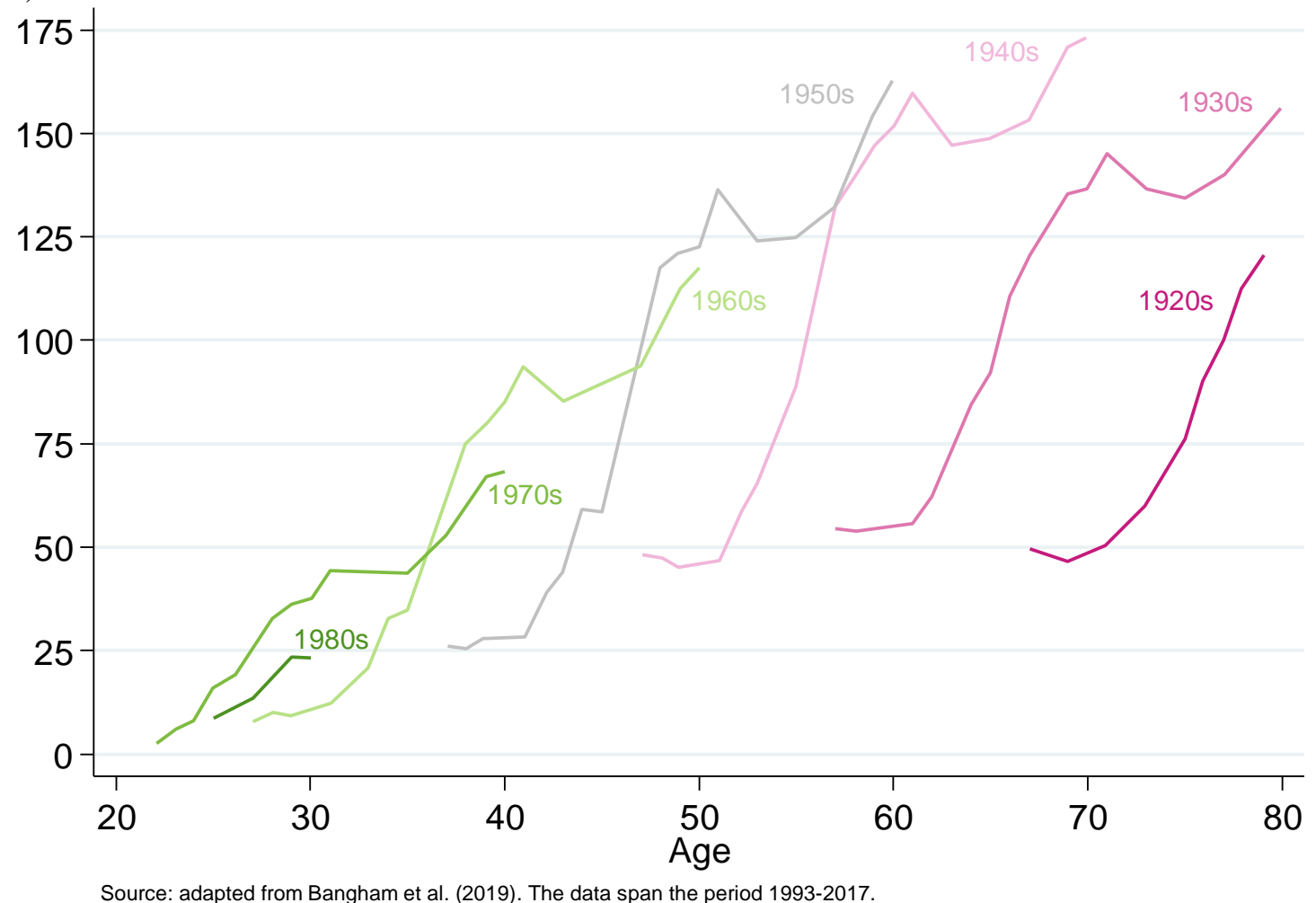

Bangham et al. (2019: 119) comment:

All cohorts born from 1960 onwards have less property wealth than their predecessors 10 years before them did at the same age. Members of the [1980s] millennial cohort are pegged back furthest ... with 39 per cent less property wealth than those born 10 years before them had at age 30 .

One might take issue with the interpretation that younger cohorts are falling behind. After all, the average property wealth held by the 1980s cohort at 30 is actually greater than that held by the 1960s cohort at the same age, and even similar to that held by the 1950 s cohort at age 40 . In that sense the 1980s cohort might appear to be doing fine even if behind those born only ten years earlier.

However that interpretation misses a key point: the explosion in housing wealth enjoyed by older cohorts through largely passive gains is unlikely to repeat for younger ones. And crucially, even if house prices do continue to rise at that rate - a situation that would probably need to involve long-term negative interest rates - lower homeownership means fewer from younger generations will be in a position to benefit. This is evident already in the greater steepness of the rightmost (i.e. most recent) parts of the lines for the 1940s, 50s, and 60s cohorts compared with their younger counterparts.

What about the other main component of personal wealth: pensions? 


\section{The loss of defined-benefit pensions}

Figure 5.2 Defined-benefit pension participation rate, by age and birth cohort (\% of employees).

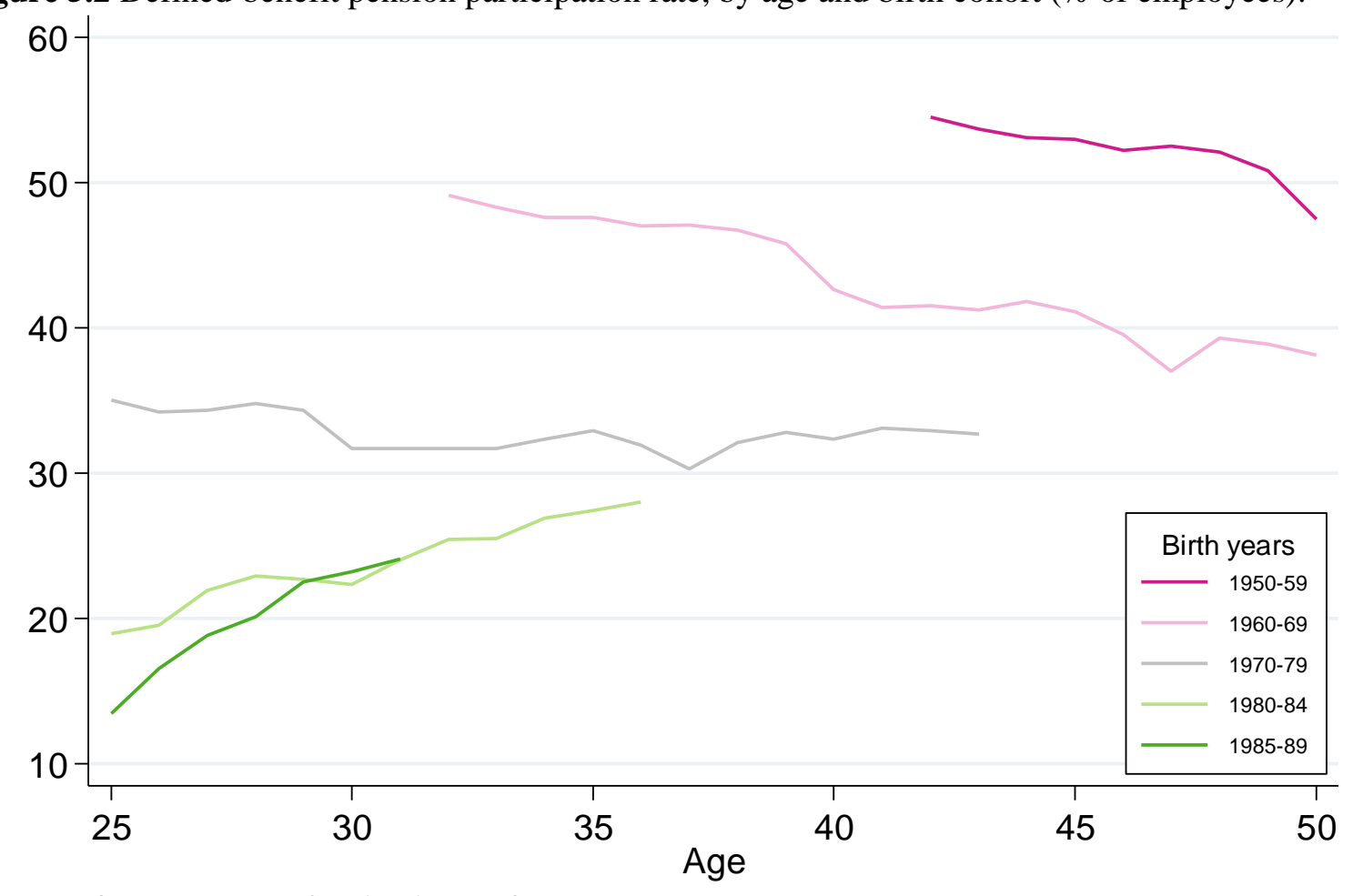

Source: adapted from Cribb (2019), Annual Survey of Hours and Earnings 1997-2018.

On the one hand, auto-enrolment into workplace pensions was mandated by the Pensions Act 2008 and phased in over the past decade, leading to a swift increase in the proportion of employees with workplace pensions - up from fewer than half in 2012 to 78\% in April 2020 (ONS, 2021b). On the other hand, workplace pensions are now overwhelmingly the defined-contribution variety, which tend to involve considerably smaller employer contributions than defined-benefit schemes. In 2015, for instance, $90 \%$ of employees on defined-benefit schemes received an employer contribution at or above $10 \%$ of their earnings, compared with just $13 \%$ of those on defined-contribution schemes (Cribb, 2019). Comparing participation in any workplace pension scheme across the generations may then paint a misleading picture. However, estimates from Cribb (2019), reproduced here as Figure 5.2, show how participation in these more generous defined-benefit schemes has fallen substantially across cohorts. Such schemes are now rare outside the public sector. Aged in their early 30s, around a quarter of employees born in the 1980s were on a defined-benefit pension scheme, compared to about half of those born in the 1960 s.

In sum, the pensions story is rather similar to that for property. Fewer members of younger generations hold the asset, and sharp increases in the value of that asset over the past couple of decades are unlikely to continue to an extent that would allow younger cohorts to keep up.

\section{Direct comparisons of wealth}

Major generational differences in homeownership and membership of defined-benefit pension schemes give strong reason to suspect that younger generations are be falling behind older in terms of their overall wealth at a given age. But what can the actual data on wealth per se tell us? 
On some topics I have been able to draw on surveys which have run year after year over the course of decades and used consistent measures. Unfortunately there is no equivalent data for wealth - no longrunning dataset accurately and representatively tracking levels of overall wealth held by people of different ages over time. Research on individual wealth has typically been based on tax data on investment income or estates at death, or on 'Rich Lists' (Alvaredo et al., 2016). All of these focus only on the very richest individuals.

In 2006, however, the Wealth and Assets Survey began as an attempt to fill this gap, and it has now been running for long enough that we can at least compare the wealth of adjacent birth cohorts at the same age. That is, for instance, we can compare average wealth held at ages 31-34 for people born 1975-79 and 1980-84. And at ages 36-39 we can compare the 1975-79 cohort with the next oldest cohort, those born 1970-74. By comparing adjacent birth cohorts in this way we can gain an accurate picture of whether, for instance, there has been a trend of successive birth cohorts not matching the wealth of those born slightly earlier.

It is important to stress the limited span of these comparisons - each five-year birth cohort is only compared to its nearest neighbours. Nonetheless, Table 5.2 shows comparisons of median wealth across adjacent birth cohorts at fixed ages. The pattern that emerges is of large cohort-on-cohort gains among the oldest, but only stability for cohorts born from the late 1950s onward. For instance, at ages 66-69, the median individual born 1945-49 held just over $£ 100,000$ (or 36\%) more than their equivalent from the 1940-44 cohort at the same ages. By contrast, no such progress was evident for any cohort from 1955-59 onwards. The small increases that appear in some cases fall within the estimates' margin of error (or in other words are not statistically significant).

Table 5.2 Cohort comparisons of median individual wealth at given ages ( $£$ thousands).

\begin{tabular}{|c|c|c|c|c|c|c|c|c|}
\hline Age & \multicolumn{3}{|c|}{ Younger cohort } & \multicolumn{3}{|c|}{ Older cohort } & \multicolumn{2}{|c|}{ Change (\%) } \\
\hline & Born & $\begin{array}{r}\text { Sample } \\
\text { size }\end{array}$ & $\begin{array}{c}\text { Median } \\
\text { wealth }\end{array}$ & Born & $\begin{array}{r}\text { Sample } \\
\text { size }\end{array}$ & $\begin{array}{l}\text { Median } \\
\text { wealth }\end{array}$ & & \\
\hline $26-29$ & $1985-89$ & 1731 & 33 & $1980-84$ & 3065 & 29 & 14 & $*$ \\
\hline $31-34$ & $1980-84$ & 2990 & 65 & $1975-79$ & 4286 & 66 & -3 & \\
\hline $36-39$ & $1975-79$ & 3320 & 111 & $1970-74$ & 5325 & 109 & 2 & \\
\hline $41-44$ & $1970-74$ & 3613 & 161 & $1965-69$ & 5198 & 155 & 4 & \\
\hline $46-49$ & $1965-69$ & 3191 & 192 & $1960-64$ & 4297 & 184 & 4 & \\
\hline $51-54$ & $1960-64$ & 3338 & 224 & $1955-59$ & 3985 & 225 & -1 & \\
\hline $56-59$ & $1955-59$ & 3838 & 315 & $1950-54$ & 5094 & 305 & 3 & \\
\hline $61-64$ & $1950-54$ & 4956 & 402 & $1945-49$ & 6700 & 321 & 25 & $* * *$ \\
\hline $66-69$ & $1945-49$ & 6083 & 381 & $1940-44$ & 6068 & 279 & 36 & $* * *$ \\
\hline $71-74$ & $1940-44$ & 4936 & 292 & 1935-39 & 5114 & 241 & 21 & $* * *$ \\
\hline $76-79$ & $1935-39$ & 3695 & 257 & $1930-34$ & 3969 & 229 & 12 & $* * *$ \\
\hline
\end{tabular}

Source: ONS Wealth and Assets Survey 2006-2018. Wealth inflated to January 2020 prices using the CPIH. Individuals living in one- or two-adult households only. Asterisks indicate statistical significance of difference: $* \mathrm{p}<0.05 * * \mathrm{p}<0.01 * * * \mathrm{p}<0.001$

Table 5.2 tells us about the wealth of the median individual in each cohort - that is, the person with more wealth than exactly half, or $50 \%$, of those in the group they represent: someone with middling wealth. However these patterns might be different when we compare the poorer or richer parts of each cohort. Tables 5.3 and 5.4 show results for individuals at the $80^{\text {th }}$ percentile (i.e. wealth greater than $80 \%$ of the group but less than the other $20 \%$, making them relatively rich), and $20^{\text {th }}$ percentile (i.e. relatively poor) respectively. One important reason to not just look at the median is that among the 
relatively poor, a comparatively small amount of wealth may be the difference between having the safety net to cope with an unexpected misfortune and falling into financial despair with its attendant social ills.

Indeed there are differences depending on whether we compare the poorer, average, or richer within each cohort: Table 5.3 shows that double-digit cohort-on-cohort percentage increases in wealth among the rich did not end with the early 1950s cohort but rather continued for cohorts born up until the late 1960s. This could reflect ownership of additional property, where younger cohorts have kept up with older (unlike main property ownership), but which is highly concentrated among the wealthiest within each cohort (Bangham, 2019). Table 5.4 paints more of a mixed picture and broadly shows that even among the 'fortunate generations', the relatively poor did not enjoy the substantial cohort-on-cohort wealth gains evident at the median, with notable reversals in some cases.

Table 5.3 Cohort comparisons of $80^{\text {th }}$ percentile individual wealth at given ages ( $£$ thousands).

\begin{tabular}{|c|c|c|c|c|c|c|c|c|}
\hline Age & \multicolumn{3}{|c|}{ Younger cohort } & \multicolumn{3}{|c|}{ Older cohort } & \multicolumn{2}{|c|}{ Change (\%) } \\
\hline & Born & $\begin{array}{r}\text { Sample } \\
\text { size }\end{array}$ & $\begin{array}{r}\text { P80 } \\
\text { wealth }\end{array}$ & Born & $\begin{array}{r}\text { Sample } \\
\text { size }\end{array}$ & $\begin{array}{r}\text { P80 } \\
\text { wealth }\end{array}$ & & \\
\hline $26-29$ & $1985-89$ & 1731 & 95 & $1980-84$ & 3065 & 75 & 26 & $* * *$ \\
\hline $31-34$ & $1980-84$ & 2990 & 154 & $1975-79$ & 4286 & 145 & 7 & \\
\hline $36-39$ & $1975-79$ & 3320 & 249 & $1970-74$ & 5325 & 242 & 3 & \\
\hline $41-44$ & $1970-74$ & 3613 & 364 & $1965-69$ & 5198 & 339 & 7 & $*$ \\
\hline $46-49$ & $1965-69$ & 3191 & 475 & $1960-64$ & 4297 & 422 & 12 & $* *$ \\
\hline $51-54$ & $1960-64$ & 3338 & 591 & $1955-59$ & 3985 & 535 & 10 & $* *$ \\
\hline $56-59$ & $1955-59$ & 3838 & 786 & $1950-54$ & 5094 & 680 & 16 & $* * *$ \\
\hline $61-64$ & $1950-54$ & 4956 & 869 & $1945-49$ & 6700 & 686 & 27 & $* * *$ \\
\hline $66-69$ & $1945-49$ & 6083 & 804 & $1940-44$ & 6068 & 591 & 36 & $* * *$ \\
\hline $71-74$ & $1940-44$ & 4936 & 633 & $1935-39$ & 5114 & 484 & 31 & $* * *$ \\
\hline $76-79$ & 1935-39 & 3695 & 511 & $1930-34$ & 3969 & 445 & 15 & $* * *$ \\
\hline
\end{tabular}

Source: see Table 5.2. P80: $80^{\text {th }}$ percentile.

Table 5.4 Cohort comparisons of $20^{\text {th }}$ percentile individual wealth at given ages ( $£$ thousands).

\begin{tabular}{|r|r|r|r|r|r|r|r|r|}
\hline & \multicolumn{3}{|c|}{ Younger cohort } & \multicolumn{3}{|c|}{ Older cohort } & & Change (\%) \\
\hline & Born & $\begin{array}{r}\text { Sample } \\
\text { size }\end{array}$ & $\begin{array}{r}\text { P20 } \\
\text { wealth }\end{array}$ & Born & $\begin{array}{r}\text { Sample } \\
\text { size }\end{array}$ & $\begin{array}{r}\text { P20 } \\
\text { wealth }\end{array}$ & \\
\hline $26-29$ & $1985-89$ & 1731 & 9 & $1980-84$ & 3065 & 8 & 12 & \\
\hline $31-34$ & $1980-84$ & 2990 & 15 & $1975-79$ & 4286 & 18 & -17 & $*$ \\
\hline $36-39$ & $1975-79$ & 3320 & 30 & $1970-74$ & 5325 & 25 & 23 & $*$ \\
\hline $41-44$ & $1970-74$ & 3613 & 43 & $1965-69$ & 5198 & 38 & 12 & \\
\hline $46-49$ & $1965-69$ & 3191 & 41 & $1960-64$ & 4297 & 37 & 11 & \\
\hline $51-54$ & $1960-64$ & 3338 & 35 & $1955-59$ & 3985 & 53 & -35 & $* * *$ \\
\hline $56-59$ & $1955-59$ & 3838 & 79 & $1950-54$ & 5094 & 96 & -17 & $*$ \\
\hline $61-64$ & $1950-54$ & 4956 & 124 & $1945-49$ & 6700 & 119 & 4 & \\
\hline $66-69$ & $1945-49$ & 6083 & 134 & $1940-44$ & 6068 & 103 & 30 & $* * *$ \\
\hline $71-74$ & $1940-44$ & 4936 & 106 & $1935-39$ & 5114 & 97 & 9 & \\
\hline $76-79$ & $1935-39$ & 3695 & 91 & $1930-34$ & 3969 & 81 & 11 & \\
\hline
\end{tabular}

Source: see Table 5.2. P20: $20^{\text {th }}$ percentile. 


\section{Summary and Conclusion}

The Future is Bright's aim in commissioning this report was to understand how opportunities and outcomes in key areas of life have changed across the generations, with special attention to education, employment, housing, and wealth. This is a broad and complex set of questions. Still, a number of trends loom large. Perhaps largest-looming of all has been an ongoing asset price boom mainly benefitting property-owning older generations, especially when considered alongside other important headwinds for younger generations, not least a decade of stagnant earnings. This boom has put homeownership and its attendant opportunity to build an asset base out of reach for many young people. That is to say nothing of the Covid pandemic, which among other ills has disrupted the education and early working life of so many young people, while also seeing house prices continue to soar. ${ }^{55}$

Having looked back over half a century of change and its implications for different generations, I now summarise those areas where progress has been made, and those where younger generations are facing problems. The Future is Bright also aimed to draw attention to the ways in which economically welloff members of older generations have benefitted from opportunities that have fallen in their favour over their lifetimes - and help them reflect on how someone starting out from their position today might not have the same things going their way. In light of this, I end with a number of suggestions individuals might consider as steps towards approaching these issues and making a positive difference.

\section{Where progress has been made}

It is undeniable that in many ways a great deal of progress has been made over the past half-century.

Perhaps the greatest long-term improvement has been in the opportunities women have had in education and in the workplace. Despite a persistent gender pay gap and persistent norms around women taking on the bulk of domestic labour, women now go to university at higher rates than men, and their labour force participation rate has grown from $56 \%$ to $76 \%$. They are more likely than ever to work in high skill occupations.

Higher education is no longer the preserve of a select few. At least by one measure, more than half of young people will have the chance to enter higher education. Members of older generations sometimes express sympathy for the fact that nowadays students pay tuition fees whereas university was free to them. However the burden of student debt is often misunderstood and overstated. Unlike in the US, student loan repayments essentially take the form of an additional income tax on graduates. While there are some concerns about the adequacy of student loans for living costs, the bigger picture is that the upfront cost of HE and the risk of 'default' on tuition fee loans are both borne by the taxpayer, granting a huge opportunity to many young people.

Changes to the economy have meant that on the whole, far more people are doing more interesting and better-paid work, not to mention enjoying higher material living standards. There has been extensive occupational upgrading, and we have seen the emergence or growth of sectors in the economy in which the UK is globally competitive, such as finance, pharmaceuticals, and the creative industries. Our higher education sector, which attracts so many overseas students, could also be included in that list. I can also mention another area of common concern which may be slightly overstated: though not comprehensive in coverage, the data do not bear out a story of decreasing job security across the generations.

\footnotetext{
55 'Rather than declining, as in previous recessions, UK house prices are now close to 10 per cent higher than when the pandemic began' (Leslie \& Shah, 2021: 33).
} 
While housing has not generally been a 'good news' story in this report, there have been positive developments. The proportion of homes meeting the 'decent' standard has rapidly increased. Investment and effort from private landlords has helped this happen. The increases in housing wealth accruing to those now around retirement age also should not only be seen through a critical lens of intergenerational equity - on the plus side this wealth will help ensure that many people can retire with peace of mind. It is not so long ago that 'pensioner' was a byword for poverty.

\section{Problems facing younger generations}

As suggested earlier, in many of the more intangible but nonetheless important aspects of life, all we can say is 'different' rather than conclusively 'better' or 'worse' when we compare the experience of different generations. Nonetheless, this report identifies some crucial areas where progress across the generations seems to be stagnating or going into reverse.

In terms of education and skills, there is a major methodological difficulty in comparing the quality of education received by successive generations. Measuring this has not been a priority. This is not to conclude that education has deteriorated across the generations - indeed that seems highly unlikely given the growing professionalisation of teaching. But anyone who has scratched their head at seeing headlines proclaiming the 'best ever exam results' seemingly every year knows we cannot rule out grade inflation. And there is only sparse evidence from studies that have attempted to base comparisons on a fixed standard. At the same time, however, it is possible to make valid cross-national comparisons, and on these measures England scores poorly when it comes to the basic skills of those who have recently completed their education.

Figure 6.1 Percentage of high skill jobs requiring a degree.

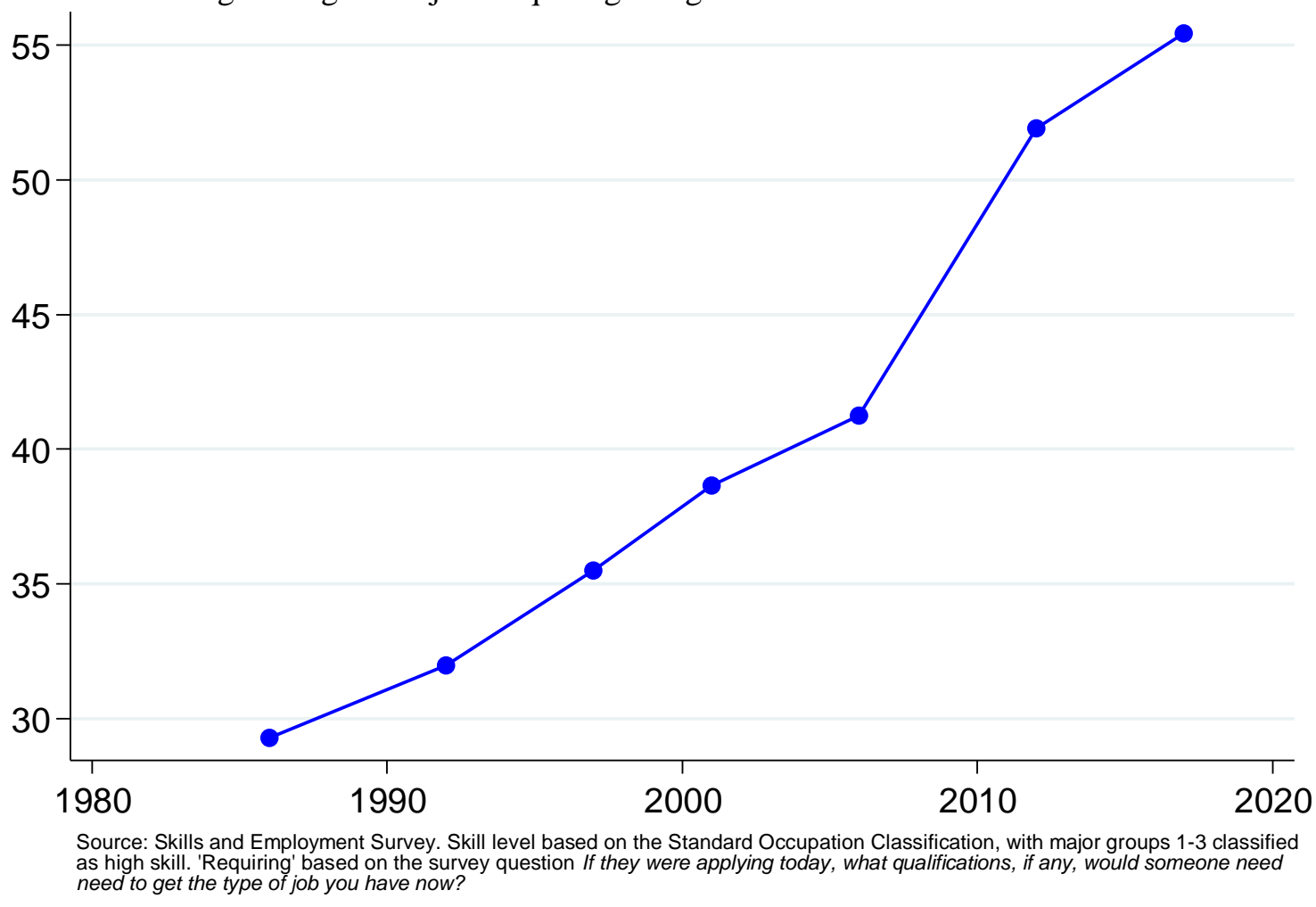


The expansion of higher education that has taken place also has major downsides. The economic returns to many courses are low and there are growing concerns about falling standards. As long as higher education grows without constraint, the process of educational expansion will draw in ever more people, each new student that wouldn't otherwise have entered increasingly doing so just in order to keep up. Moreover recent trends and the incentive structure currently in place suggest that incremental new student is likely to opt for a course of questionable value. It should not be ignored that this all adds to public spending and that close to half of student debt is not expected to be repaid. Student loans are forecast to increase UK public debt by 12\% of GDP by 2040 (Bolton, 2021b). I do not make this argument out of an antipathy to higher education - far from it - but it must be weighed against alternatives. Higher education expansion has roared on alongside funding cuts to adult and vocational training and public libraries, a decade-long pay squeeze on teachers, and spending on early years education that is low by international standards, when there is much to suggest that this is the most effective stage at which to concentrate funding.

While about half still do not go to university, educational expansion has nonetheless had life-changing implications for them. Their non-graduate status today pre-emptively closes off many opportunities which for previous generations might have been accessible to those with promise but without credentials, or who could enter a firm at a junior level and work their way up. This is reflected in a neardoubling between 1986 and 2017 of the proportion of 'high skill' jobs which require a degree (Figure 6.1). Young non-graduates today do not have the same chances as their predecessors of securing meaningful further training in the form of a vocational qualification or apprenticeship, a point made repeatedly by official reviews of vocational and post-secondary education (Augar et al., 2019; Wolf, 2011). The situation as a whole can only be expected to result in greater-than-ever pressure on students to do well in their academic exams, a trend reflected in the growing use of private tutors.

Figure 6.2 Median annual pre-tax earnings of those in paid work, by age and birth cohort ( $£$ thousands, 2017-18 prices).

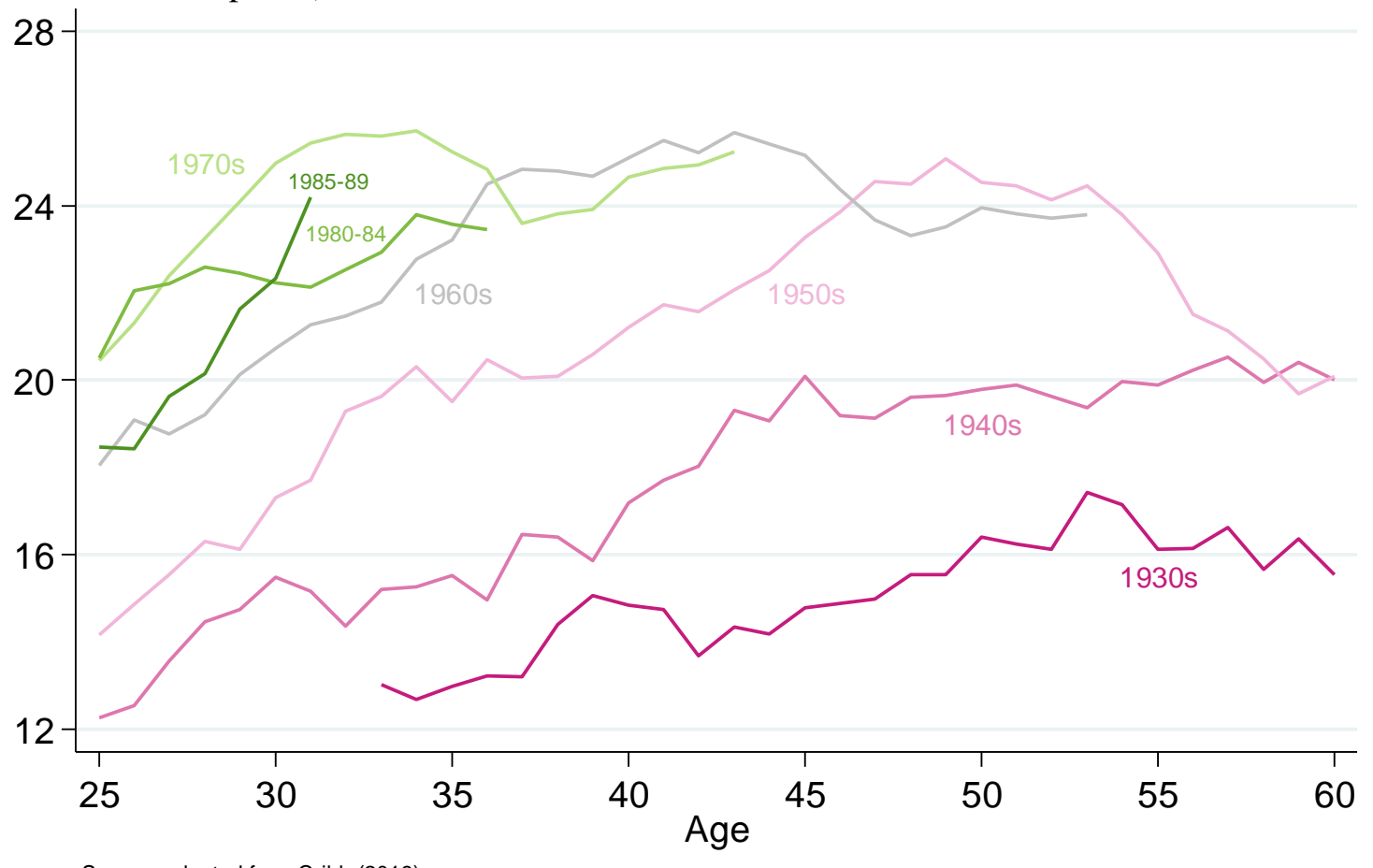

Source: adapted from Cribb (2019).

Turning to employment and earnings, the fact that productivity and wages have been stagnant since the financial crisis poses a major problem. A pattern of rising earnings across the generations has come to a halt with the Millennials (Figure 6.2). Every generation since the Baby Boomers has faced high levels 
of youth unemployment. Younger cohorts are beginning their careers lower down the occupational ladder and seeing slower career progression over their early working lives. Far more are in low skill work at a given age and far fewer in medium skill work, reflecting a pattern of polarisation in the labour market that has particularly affected younger generations and especially young men. Labour economists reach the conclusion of a 'generational contraction of job opportunities for men not in top occupations' (Cristini et al., 2018: 201).

It is with respect to housing that the intergenerational contrast is most striking. We often talk of a housing 'ladder' but for many Baby Boomers the more apt metaphor is that of a golden escalator (Figure 6.3); they bought first homes in the 1970, 80s, and early 90s, before house prices began a sharp and sustained rise. Some economists argue both that this has been driven by falling interest rates - now very close to zero - and that we are in an era of secular stagnation in which there is little prospect that interest rates will rise to levels seen in previous decades. Aided by this (untaxed) windfall and other policy inducements, a substantial minority of Baby Boomers now own multiple properties. While this is generally seen as a safe investment for the individual, such investment does little to stimulate economic growth, increases prices for would-be occupiers, and in the case of buy-to-let generally opens a channel for a transfer of wealth from younger to older in place of enforced saving through mortgage repayments. In the case of second homes the result is the under-occupation of housing in desirable locations with constrained supply.

Figure 6.3 Mean family net property wealth per adult, by age and birth cohort ( $£$ thousands, 2018-19 prices).

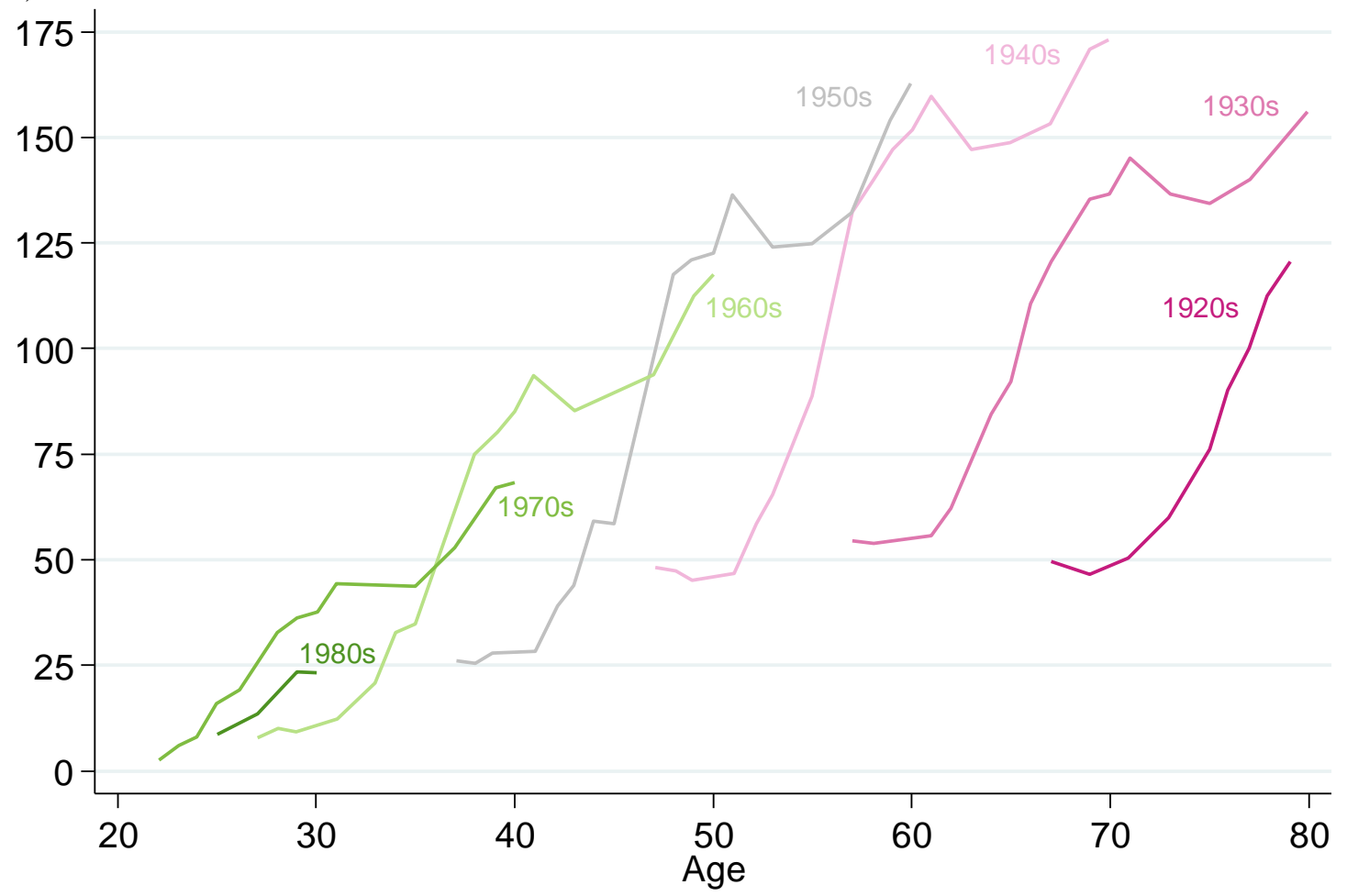

Source: adapted from Bangham et al. (2019). The data span the period 1993-2017.

Millennials without access to parental wealth are largely priced out of buying a home; accordingly rates of homeownership are far lower than for previous generations (Figure 6.4). At the same time, the stock of below market rent social housing has declined - an amenity enjoyed by large numbers of Baby Boomers as young adults. Younger generations are much more likely to continue to live with their parents (the proportion doing so at age 25 has doubled) or to rent privately. A far higher portion of their household income goes on housing costs than earlier generations'. This is especially true of private 
renters, a population now including more young families than ever before, not just single young professionals or couples seeking flexibility. Though aspects of private renting have improved, tenants still know that they may be evicted with two months' notice, which is not conducive to putting down roots in a community and having children, let alone providing them with a family environment characterised by stability.

Figure 6.4 Homeownership, by age and birth cohort (\%).

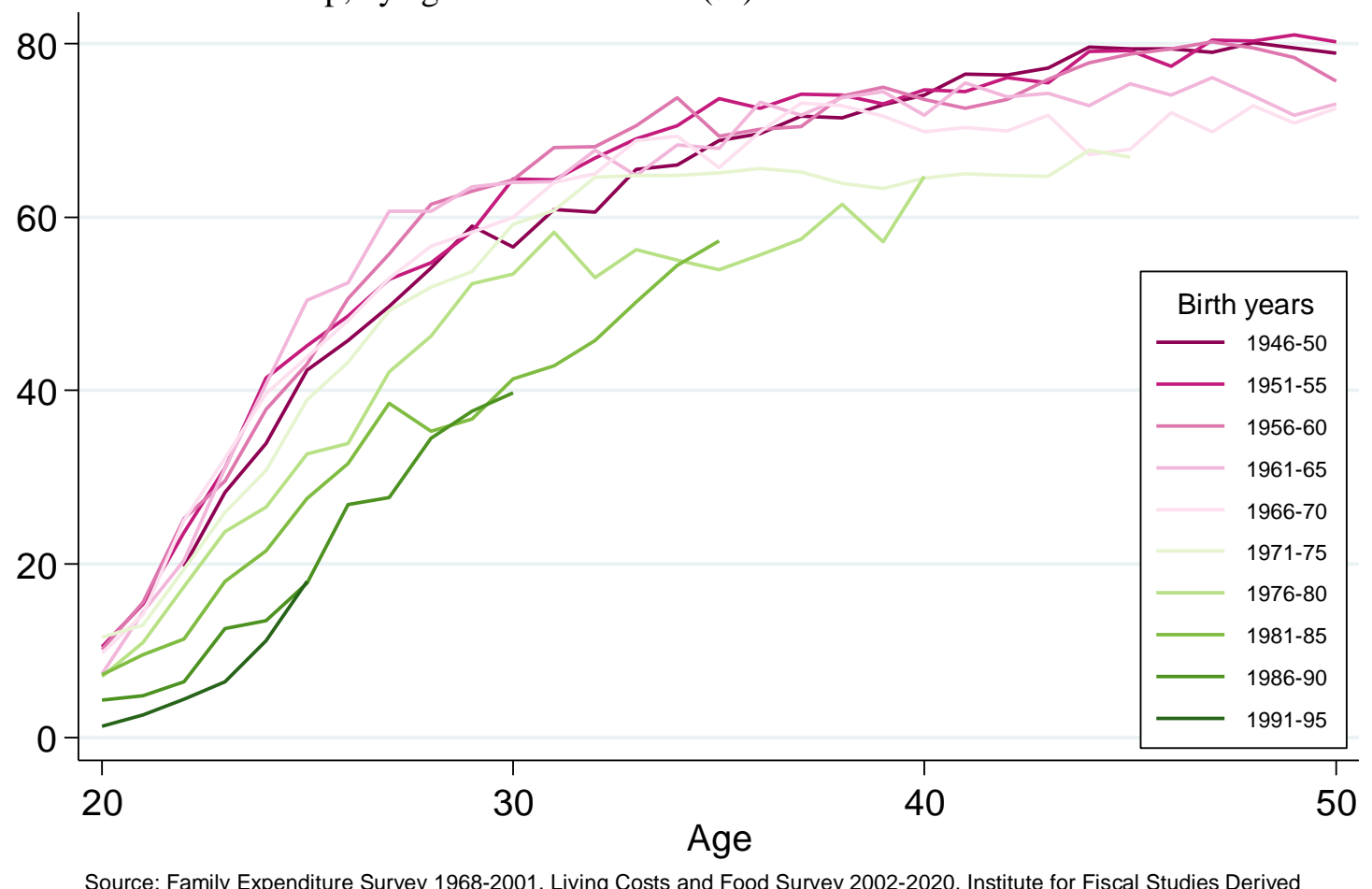

Source: Family Expenditure Survey 1968-2001, Living Costs and Food Survey 2002-2020. Institute for Fiscal Studies Derived Variables Dataset, updated with most recent data.

Research into the distribution of personal wealth has long been stymied by the difficulties of collecting data that is both accurate and representative of the whole population (Alvaredo et al., 2016). Such data have only been collected from 2006 onwards, meaning that the overlap in our observations of different generations at the same age is minimal. Comparing five-year birth cohorts to those born five years earlier at the same age, however, the pattern that emerges is of large cohort-on-cohort gains among the oldest, but only stability among cohorts from the late 1950s onward. The data do not permit easy comparisons between generations at the same age, and we would naturally expect wealth to be concentrated among cohorts close to retirement age. Nonetheless, the degree to which wealth is concentrated among the Baby Boomer generation is striking, and the extent of this wealth concentration can be largely attributed to favourable and unlikely-to-be-repeated macroeconomic conditions - most notably the effect of low interest rates on house prices and pension entitlements (Bangham et al., 2019). With low homeownership among younger generations and the decline of defined-benefit pensions, it is likely that younger generations have fallen or at least will fall quite dramatically behind in terms of wealth over their working age lives.

There is one measure that didn't quite seem to fit any of the main chapters. But in all likelihood it matters a great deal. When we think of a young person with a life characterised by stability and the opportunity to learn, explore, and develop, most of us probably think of a stable, two-parent family. But this environment has been on the decline, as shown in Figure 6.5. There is every reason why a separation may be the right decision in any particular case, but the trend below will be of concern to many, and in part is probably indicative of a growing strain arising from many of the problems discussed in this 
report. For instance, though it is just a correlation and there are other factors at play, it is striking that in the UK, couples who own their own homes have a 63\% lower divorce rate (Boertien \& Härkönen, 2018).

Figure 6.5 Percentage living with both parents from birth to age 16, by year of birth.

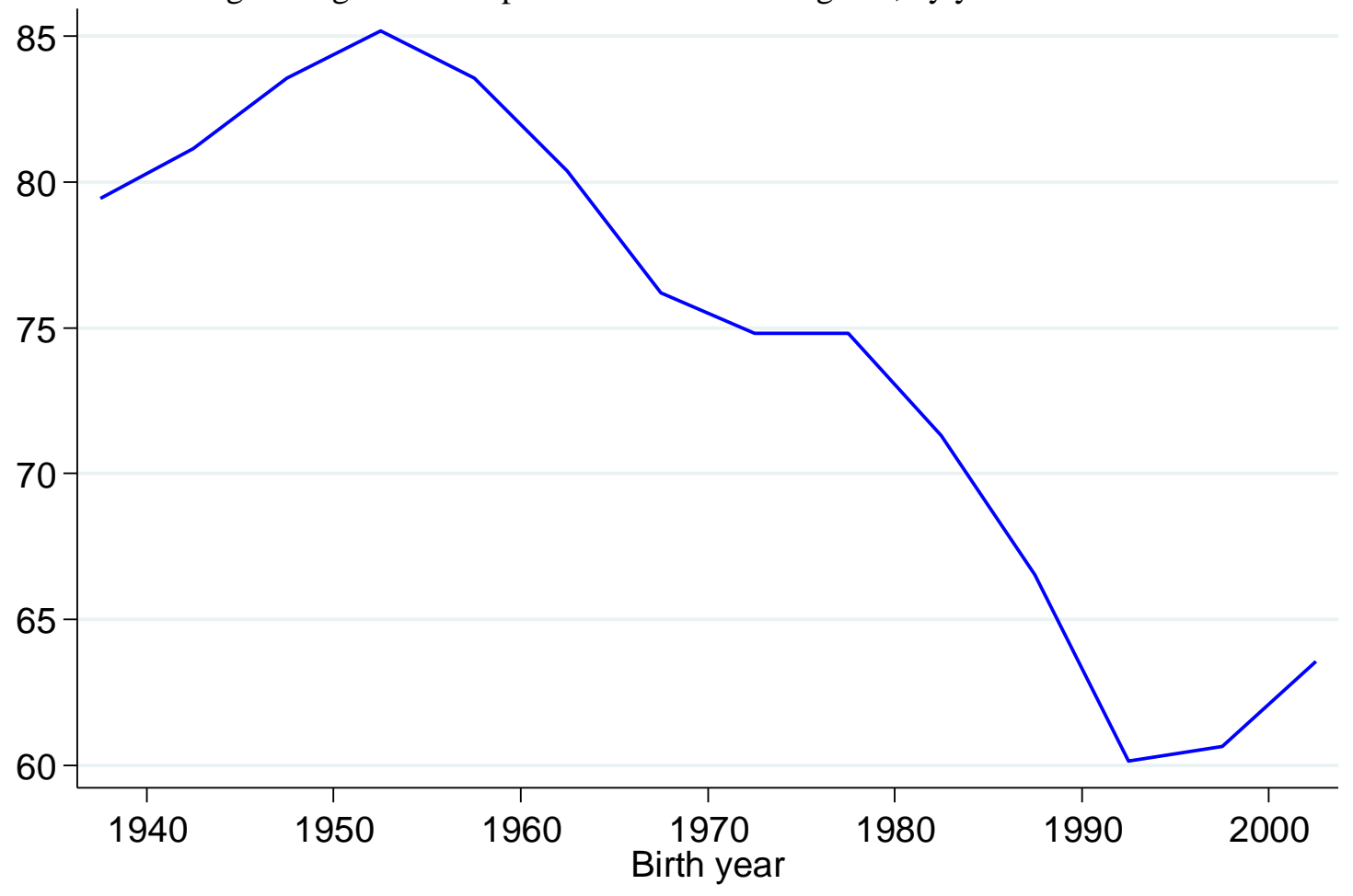

Source: British Household Panel Survey 2003, UK Household Longitudinal Study 2009-2019.

\section{Suggestions for action}

I end this report with some suggestions of what members of older generations might be able to do to help pass on opportunities to young people. Many charities and think tanks focus - quite rightly - on informing and influencing policymakers. ${ }^{56}$ The Future is Bright believes that putting the case to individuals and asking them to consider the role they can play is also a valuable strategy for change.

\footnotetext{
${ }^{56}$ For some detailed policy options relating to the main issues discussed in this report, see in particular the final report of the Resolution Foundation Intergenerational Commission (2018), which contains, among other things, detailed proposals for reforming the taxation of wealth. Also see Muellbauer (2018) - a must-read for anyone interested in and/or puzzled by the UK housing market - which outlines a green land value tax and proposes reform of the planning system. At the core of the planning reform is capturing the 'planning gain' - the increase in land value arising purely from the granting of planning permission - for the public finances rather than allowing it to form the core of housebuilders' business model. This could fund social housing, incentivise the granting of planning permission, and force housebuilders to compete on the quality of their builds rather than make their money through land speculation. The green land value tax - based on taxing property annually rather than taxing transactions - has many potential benefits (Muellbauer, 2021), including incentivising efficient (and energy efficient) use of housing, stabilising the economy as a whole, reducing regional inequality (Duca et al., 2021b), improving access for the young, and removing a barrier to labour mobility, in turn aiding economic growth. The latter proposal is echoed in the recommendations of the OECD's (2021a) recent report on housing policies. Note that the proposal allows for payment to be deferred in certain circumstances, to cope with the issue of some households being land-rich but cash-poor. Lastly, Rodrik \& Stantcheva (2021) detail policy options for addressing labour market polarisation and creating 'good jobs'.
} 
These suggestions are informed by the findings above, but vary from the quite clear and concrete to the speculative and exploratory. Even if none are palatable or suit readers' circumstances, I hope the evidence presented here will provoke thought and discussion about the directions in which our society is heading.

\section{Education and employment}

- If you are in a position to influence an organisation's recruitment policy, consider abolishing any requirements for credentials such as a degree where there is no specific link between the qualification and the competency required for the role. Early movers in this area will get the first pick of a pool of able candidates previously overlooked by default. Some large and respected organisations have already begun to recognise this. ${ }^{57}$

- If you are in a senior position at a company, consider formalising an intergenerational agenda analogous to many organisations' sustainability or environmental impact agenda. In addition to the point above, this could involve a greater emphasis on workplace training beyond statutory minimums, offering work experience placements, committing to take on a certain proportion of school-leavers, and measures to increase vertical mobility within the organisation, especially of non-graduates with a strong record into management positions.

- If you have recently retired, consider making contact with a local school, further education college, or youth charity such as Future First. There may be a role for you as an informal mentor. Even something as simple as reviewing school leavers' CVs or giving them practice job interviews could be of immense value in young people's lives.

- Consider (re)training as a tutor and offering free or subsidised lessons to students falling behind.

\section{Housing}

- If you own a home with multiple spare bedrooms, consider selling it to a young family. Under the current system, housebuilding happens very slowly in this country. But it is not the only way to increase housing supply. Freeing up under-occupied property is another way (Scanlon, 2014).

- Some might also consider an intergenerational homeshare arrangement, whereby young people in need of affordable accommodation stay in a spare room and lend a hand around the house. See the website of Homeshare UK for more information.

- If you own a second home, consider selling it to someone who wants it as a main residence.

- If you are a landlord, especially one with tenant(s) you know to be generally well-behaved and reliable when it comes to paying the rent, consider offering them a rental agreement with a much longer term, or selling to them.

- Consider writing to your MP and asking why the government has not yet implemented its stated intention of a register of beneficial ownership for UK property (Shalchi \& Mor, 2021). Under the current situation whereby owners of UK property do not have to disclose their identity, it is widely believed that an important portion of the demand driving up property prices comes from illicit sources and ultimately flows from a great deal of crime and suffering.

\footnotetext{
${ }^{57}$ The current norm for large organisations is to compete for graduates who have worked hard to prove they have the qualities to succeed in education. But performance at degree level is likely to correlate strongly with performance in secondary education. Companies that are willing to offer jobs to school-leavers - to make the offer that 'if you are heading to university only because that's the norm if you want a well-paying job, then instead come and work for us' - would be taking a risk but at the same time would be among a small number picking from a potentially large field of talented candidates. These employees would still have the opportunity to go to university later if desired.
} 
- If you are in a position to influence the direction of new investment, consider sectors that will create stable, medium-skill jobs open to non-graduates. Many green industries such as electrification of home heating and cooling, and home insulation seem like promising areas (Griffith \& Calisch, 2020). The products have many benefits, not least greater energy independence for the UK, and the jobs are necessarily spread up and down the country. Besides directly investing, property owners can of course support these industries by purchasing their products to upgrade their properties.

- If property is the main or only component of your investment portfolio, consider switching or diversifying into more productive assets. Property is not the only 'safe' investment, if safety is what you want. With little further for interest rates to fall, the current pattern of increasing property values is surely unlikely to continue at the same high rate, and may not continue at all. And consider that despite the huge increase in the value of UK property over the past 25 years, global equities have had even better returns, according to Schroders (Lamont, 2021). Consult your local chamber of commerce for opportunities that can help create good jobs in your area.

- If you have invested in property specifically to buffer yourself against the risk of catastrophically high care costs, consider whether this is still necessary in light of the government's recent announcement of proposed reforms to social care funding including the introduction of a cap on how much individuals will pay towards their own social care costs.

\section{The longer view}

- As well as thinking about the society you want your children and grandchildren to live in, take the longer view. Reduce your consumption of resources we will only ever get to use once. Taking fewer flights, buying fewer new things, and eating less (highly resource-intensive) red meat are all quiet gifts to your descendants. 


\section{References}

Aber, J. L., Bennett, N. G., Conley, D. C., \& Jiali, L. (1997). The Effects of Poverty on Child Health and Development. Annual Review of Public Health, 18, 463-483.

Aksoy, C. G. (2016). Short-Term Effects of House Prices on Birth Rates (EBRD Working Paper No. 192). European Bank for Reconstruction and Development.

Alvaredo, F., Atkinson, A. B., \& Morelli, S. (2016). The Challenge of Measuring UK Wealth Inequality in the 2000s. Fiscal Studies, 37(1), 13-33.

Andrews, J., \& Perera, N. (2017). The impact of academies on educational outcomes. Education Policy Institute.

Arum, R., \& Roksa, J. (2011). Academically Adrift: Limited Learning on College Campuses. Chicago: University of Chicago Press.

Augar, P., Crewe, I., de Rojas, J., Peck, E., Robinson, B., \& Wolf, A. (2019). Independent panel report to the Review of Post-18 Education and Funding. Department for Education: London.

Badarinza, C., \& Ramadorai, T. (2018). Home away from home? Foreign demand and London house prices. Journal of Financial Economics, 130(3), 532-555.

Bailey, N. (2020). Poverty and the re-growth of private renting in the UK, 1994-2018. PLOS ONE, $15(2), \mathrm{e} 0228273$.

Bangham, G. (2019). Game of Homes: The rise of multiple property ownership in Great Britain. Resolution Foundation.

Bangham, G., Clarke, S., Gardiner, L., Judge, L., Rahman, F., \& Tomlinson, D. (2019). Intergenerational Audit 2019. Resolution Foundation.

Barker, N. (2017, December 7). Revealed: The scale of ex-RTB home conversions to private rent. Retrieved 8 February 2022, from https://www.insidehousing.co.uk/insight/insight/revealedthe-scale-of-ex-rtb-home-conversions-to-private-rent-53525

Barr, C., \& Malik, S. (2016, March 14). Young families priced out of rental markets in two-thirds of the UK. The Guardian.

BEIS. (2018). A REGISTER OF BENEFICIAL OWNERS OF OVERSEAS COMPANIES AND OTHER LEGAL ENTITIES: Understanding the potential impacts of the proposed register through qualitative interviews with industry stakeholders (BEIS Research Paper No. 13). London: Department for Business, Energy \& Industrial Strategy.

Belfield, C., Crawford, C., \& Sibieta, L. (2018). Long-run comparisons of spending per pupil across different stages of education. Institute for Fiscal Studies.

Bell, D. N. F., \& Blanchflower, D. G. (2011). Young people and the Great Recession. Oxford Review of Economic Policy, 27(2), 241-267.

BIS. (2013). The International Survey of Adult Skills 2012: Adult literacy, numeracy and problem solving skills in England (BIS Research Paper No. 139). London: Department for Business, Innovation \& Skills.

Blanden, J., \& Macmillan, L. (2016). Educational Inequality, Educational Expansion and Intergenerational Mobility. Journal of Social Policy, 45(4), 589-614.

Blundell, R., Costa-Dias, M., Joyce, R., \& Keiller, A. N. (2020). What has been happening to career progression? (IFS Briefing Note No. BN301). Institute for Fiscal Studies.

Blundell, R., Green, D. A., \& Wenchao, J. (2016). The UK Wage Premium Puzzle-How Did a Large Increase in University Graduates Leave the Education Premium Unchanged? (IFS Working Paper No. W16/01). London: Institute for Fiscal Studies. Retrieved from https://ifs.org.uk/uploads/publications/wps/WP201601.pdf

Boertien, D., \& Härkönen, J. (2018). Why does women's education stabilize marriages? The role of marital attraction and barriers to divorce. Demographic Research, 38(41), 1241-1276.

Boliver, V. (2011). Expansion, differentiation, and the persistence of social class inequalities in British higher education. Higher Education, 61(3), 229-242.

Boliver, V. (2017). Misplaced optimism: How higher education reproduces rather than reduces social inequality. British Journal of Sociology of Education, 38(3), 423-432.

Bolton, P. (2008). Teachers' pay statistics (Standard Note No. SN/SG/1877). House of Commons Library. Retrieved from https://dera.ioe.ac.uk/22821/1/SN01877.pdf 
Bolton, P. (2020). Education spending in the UK (Briefing Paper No. 1078). House of Commons Library. Retrieved from https://commonslibrary.parliament.uk/research-briefings/sn01078

Bolton, P. (2021a). Higher education funding in England (Briefing Paper No. 7393). House of Commons Library.

Bolton, P. (2021b). Student Loan Statistics (Research Briefing No. CBP01079). House of Commons Library.

Bradshaw, C. J. A. (2019, September 9). Academic? You're just a cash-hamster spinning a publisher's profit wheel. Retrieved from https://conservationbytes.com/2019/09/09/academicyoure-just-a-cash-hamster-spinning-a-publishers-profit-wheel/

Brand, J. E. (2015). The Far-Reaching Impact of Job Loss and Unemployment. Annual Review of Sociology, 41(1), 359-375.

Britton, J., Dearden, L., van der Erve, L., \& Waltmann, B. (2020a). The impact of undergraduate degrees on lifetime earnings. London: Institute for Fiscal Studies. Retrieved from https://ifs.org.uk/publications/14729

Britton, J., Farquharson, C., Sibieta, L., Tahir, I., \& Waltmann, B. (2020b). 2020 annual report on education spending in England (IFS Report No. R183). London: Institute for Fiscal Studies.

Brooks, R., \& Eriksson, C. (2016). Tax Havens: Selling England By The Offshore Pound (Special Report). London: Private Eye.

Bukodi, E., Erikson, R., \& Goldthorpe, J. H. (2014). The effects of social origins and cognitive ability on educational attainment: Evidence from Britain and Sweden. Acta Sociologica, 57(4), 293310.

Bukodi, E., \& Goldthorpe, J. H. (2019). Social mobility and education in Britain: Research, politics and policy. Cambridge: Cambridge University Press.

Buranyi, S. (2017, June 27). Is the staggeringly profitable business of scientific publishing bad for science? The Guardian. Retrieved from https://www.theguardian.com/science/2017/jun/27/profitable-business-scientific-publishingbad-for-science

Buscha, F., Gorman, E., \& Sturgis, P. (2021). Selective Schooling Has Not Promoted Social Mobility in England (IZA Discussion Paper No. 14640). IZA Institute of Labor Economics.

Bynner, J., Schuller, T., \& Feinstein, L. (2003). Wider benefits of education: Skills, higher education and civic engagement. Zeitschrift Für Pädagogik, 49(3), 341-361.

Callender, C., \& Mason, G. (2017). Does Student Loan Debt Deter Higher Education Participation? New Evidence from England. The ANNALS of the American Academy of Political and Social Science, 671(1), 20-48.

Caplan, B. (2018). The Case Against Education: Why the Education System is a Waste of Time and Money. Princeton: Princeton University Press.

Chevalier, A., \& Lindley, J. (2009). Overeducation and the skills of UK graduates. Journal of the Royal Statistical Society: Series A (Statistics in Society), 172(2), 307-337.

Clark, D., \& Royer, H. (2013). The Effect of Education on Adult Mortality and Health: Evidence from Britain. American Economic Review, 103(6), 2087-2120.

Coe, R. (2007). Changes in standards at GCSE and A--Level: Evidence from ALIS and YELLIS. CEM Centre, Durham University. Retrieved from http://www.cem.org/attachments/ONS\%20report\%20on\%20changes\%20at\%20GCSE\%20and $\% 20 \mathrm{~A}-$ level.pdf

Coe, R. (2013). Improving Education: A triumph of hope over experience (Inaugral Lecture). Centre for Evaluation \& Monitoring, Durham University.

Cooper, J., Lord, A., \& Massey, D. (2019, May 30). What has happened to the hourly and weekly pay of NLW workers? Retrieved 27 June 2021, from https://minimumwage.blog.gov.uk/2019/05/30/what-has-happened-to-the-hourly-and-weeklypay-of-nlw-workers/

Corlett, A., \& Clarke, S. (2017). Living Standards 2017: The past, present and possible future of UK incomes. Resolution Foundation.

Corlett, A., \& Judge, L. (2017). Home Affront: Housing across the generations. Resolution Foundation. 
Cribb, J. (2019). Intergenerational Differences in Income and Wealth: Evidence from Britain. Fiscal Studies, 40(3), 275-299.

Cribb, J., Hood, A., Joyce, R., \& Keiller, A. N. (2017). Living standards, poverty and inequality in the $U K:$ 2017. Institute for Fiscal Studies.

Cribb, J., \& Sibieta, L. (2021). The long, long squeeze on teacher pay. Institute for Fiscal Studies. Retrieved from https://ifs.org.uk/publications/15552

Cribb, J., \& Simpson, P. (2018). Barriers to homeownership for young adults. In C. Emmerson, C. Farquharson, \& P. Johnson (Eds.), The IFS Green Budget (pp. 279-310). London: The Institute for Fiscal Studies.

Cristini, A., Geraci, A., \& Muellbauer, J. (2018). Sifting through the ASHE: Job Polarisation and Earnings Inequality in the UK, 1975-2015. In B. Nolan (Ed.), Generating Prosperity for Working Families in Affluent Countries. Oxford: Oxford University Press.

Croucher, R., \& White, G. (2011). The impact of minimum wages on the youth labour market: An international literature review for the Low Pay Commission. London: The Low Pay Commission.

D'Arcy, C., \& Gardiner, L. (2017). The Generation of Wealth: Asset accumulation across and within cohorts. Resolution Foundation.

Davies, N. M., Dickson, M., Davey Smith, G., Windmeijer, F., \& van den Berg, G. J. (2019). The Causal Effects of Education on Adult Health, Mortality and Income: Evidence from Mendelian Randomization and the Raising of the School Leaving Age (Working Paper No. 2019- 029). University of Chicago: Human Capital and Economic Opportunity Global Working Group. Retrieved from http://humcap.uchicago.edu/RePEc/hka/wpaper/Davies_Dickson_DaveySmith_etal_2019_causal-effects-ed-adult-health.pdf

DCLG. (2016). English Housing Survey: First Time Buyers and Potential Home Owners Report, 2014-15. London: Department for Communities and Local Government.

Dickerson, A., \& Morris, D. (2019). The Changing Demand for Skills in the UK (Research Discussion Paper No. 020). London: Centre for Vocational Education Research, London School of Economics \& Political Science.

DLUHC, \& MHCLG. (2022a, January 13). Live tables on housing supply: Indicators of new supply: Table 213 [Statistical data set]. Retrieved 8 February 2022, from https://www.gov.uk/government/statistical-data-sets/live-tables-on-house-building

DLUHC, \& MHCLG. (2022b, January 27). Live tables on social housing sales: Table 678 [Statistical data set]. Retrieved 8 February 2022, from https://www.gov.uk/government/statistical-datasets/live-tables-on-social-housing-sales

Duca, J., Muellbauer, J., \& Murphy, A. (2021a, September 13). What drives house prices: Lessons from the literature. Retrieved 22 January 2022, from https://voxeu.org/article/what-driveshouse-prices-some-lessons-literature

Duca, J. V., Muellbauer, J., \& Murphy, A. (2021b). What Drives House Price Cycles? International Experience and Policy Issues. Journal of Economic Literature, 59(3), 773-864.

Duncan, G. J., Brooks-Gunn, J., \& Klebanov, P. K. (1994). Economic Deprivation and Early Childhood Development. Child Development, 65(2), 296-318.

Easterlin, R. A. (1976). The Conflict between Aspirations and Resources. Population and Development Review, 2(3/4), 417-425.

Elias, P., \& Purcell, K. (2013). Classifying graduate occupations for the knowledge society (Futuretrack Working Paper No. 5). Institute for Employment Research, University of Warwick.

Ermisch, J. (2021). English fertility heads south: Understanding the recent decline. Demographic Research, 45(29), 903-916.

Evans, R. (2011). Short History of Apprenticeships. Retrieved 28 May 2021, from https://technicaleducationmatters.org/2011/01/06/short-history-of-apprenticeships/

Eyles, A., \& Machin, S. (2019). The Introduction of Academy Schools to England's Education. Journal of the European Economic Association, 17(4), 1107-1146.

Eyles, A., Machin, S., \& Silva, O. (2018). Academies 2 - The New Batch: The Changing Nature of Academy Schools in England. Fiscal Studies, 39(1), 121-158. 
Farquharson, C. (2021). Complicated, costly and constantly changing: The childcare system in England (Observation). Institute for Fiscal Studies. Retrieved from https://ifs.org.uk/publications/15612

Felstead, A., Gallie, D., Green, F., \& Henseke, G. (2018). Insecurity at Work in Britain: First Findings from the Skills and Employment Survey 2017. London: Centre for Learning and Life Chances in Knowledge Economies and Societies, UCL Institute of Education.

Flood, A. (2019, December 6). Britain has closed almost 800 libraries since 2010, figures show. The Guardian. Retrieved from https://www.theguardian.com/books/2019/dec/06/britain-hasclosed-almost-800-libraries-since-2010-figures-show

Frank, R. H. (2016). Success and Luck: Good Fortune and the Myth of Meritocracy. Princeton: Princeton University Press.

Friedman, S., \& Laurison, D. (2019). The Class Ceiling: Why It Pays to be Privileged. Bristol: Policy Press.

Gallie, D., Felstead, A., Green, F., \& Henseke, G. (2018). Participation at Work in Britain: First Findings from the Skills and Employment Survey 2017. London: Centre for Learning and Life Chances in Knowledge Economies and Societies, UCL Institute of Education.

Gallie, D., Felstead, A., Green, F., \& Inanc, H. (2014). The quality of work in Britain over the economic crisis. International Review of Sociology, 24(2), 207-224.

Geary, F., \& Stark, T. (2016). What happened to regional inequality in Britain in the twentieth century? The Economic History Review, 69(1), 215-228.

Goodhart, D. (2020). Head, Hand, Heart: The Struggle for Dignity and Status in the 21st Century. London: Allen Lane.

Goos, M., \& Manning, A. (2007). Lousy and Lovely Jobs: The Rising Polarization of Work in Britain. The Review of Economics and Statistics, 89(1), 118-133.

Green, F. (2021). British teachers' declining job quality: Evidence from the Skills and Employment Survey. Oxford Review of Education, 47(3), 386-403.

Green, F., Felstead, A., Gallie, D., \& Henseke, G. (2018). Work Intensity in Britain: First Findings from the Skills and Employment Survey 2017. London: Centre for Learning and Life Chances in Knowledge Economies and Societies, UCL Institute of Education.

Green, F., \& Zhu, Y. (2010). Overqualification, job dissatisfaction, and increasing dispersion in the returns to graduate education. Oxford Economic Papers, 62(4), 740-763.

Gregg, P. (2001). The Impact of Youth Unemployment on Adult Unemployment in the NCDS. The Economic Journal, 111(475), F626-F653.

Gregg, P., \& Tominey, E. (2005). The wage scar from male youth unemployment. Labour Economics, 12(4), 487-509.

Griffith, S., \& Calisch, S. (2020). Mobilizing for a zero carbon America-Jobs, jobs, jobs, and more jobs. Rewiring America. Retrieved from https://www.rewiringamerica.org/jobs-report

Guo, G., \& Harris, K. M. (2000). The mechanisms mediating the effects of poverty on children's intellectual development. Demography, 37(4), 431-447.

Heath, A. (2018). Social Progress in Britain. Oxford: Oxford University Press.

Heckman, J. J. (2006). Skill Formation and the Economics of Investing in Disadvantaged Children. Science, 312(5782), 1900-1902.

Henseke, G., Felstead, A., Gallie, D., \& Green, F. (2018). Skills trends at work in Britain-First findings from the Skills and Employment Survey 2017. London: Centre for Learning and Life Chances in Knowledge Economies and Societies, UCL Institute of Education.

Hilber, C. A. L., \& Mense, A. (2021). Why have house prices risen so much more than rents in superstar cities? (Discussion Paper No. 1743). Centre for Economic Performance, London School of Economics and Political Science.

IFF Research. (2017). Apprenticeships evaluation 2017: Learners (Research report). Department for Education. Retrieved from https://assets.publishing.service.gov.uk/government/uploads/system/uploads/attachment_data/ file/659709/Apprenticeships_evaluation_2017-learners.pdf

Ilzetzki, E. (2020, March 11). Explaining the UK's productivity slowdown: Views of leading economists. Retrieved 14 October 2021, from https://voxeu.org/article/uk-productivitypuzzle-cfm-survey 
Jerrim, J. (2013). The Reliability of Trends over Time in International Education Test Scores: Is the Performance of England's Secondary School Pupils Really in Relative Decline? Journal of Social Policy, 42(2), 259-279.

Judge, L., \& Leslie, J. (2021). Stakes and ladders: The costs and benefits of buying a first home over the generations. Resolution Foundation.

Kay, J. (2016). Other People's Money. London: Profile Books.

Kayal, M., Ballard, J., \& Kayal, E. (2021). Towards a more sustainable academic publishing system. ArXiv, 2101.06834.

Kiernan, K. E., \& Huerta, M. C. (2008). Economic deprivation, maternal depression, parenting and children's cognitive and emotional development in early childhood 1. British Journal of Sociology, 59(4), 783-806.

Kuczera, M., Field, S., \& Windisch, H. C. (2016). Building Skills for All: A Review of EnglandPolicy Insights from the Survey of Adult Skills (OECD Skills Studies). Paris: OECD Publishing.

Lambert, H. (2019, August 21). The great university con: How the British degree lost its value. The New Statesman. Retrieved from https://www.newstatesman.com/politics/2019/08/the-greatuniversity-con-how-the-british-degree-lost-its-value

Lamont, D. (2021, March 15). What 175 years of data tell us about house price affordability in the UK. Retrieved 21 September 2021, from https://www.schroders.com/en/uk/privateinvestor/insights/markets/what-174-years-of-data-tell-us-about-house-price-affordability-inthe-uk/

Leslie, J., \& Shah, K. (2021). (Wealth) gap year: The impact of the coronavirus crisis on UK household wealth. Resolution Foundation.

Lewis, J., \& Cumming, F. (2019, September 6). Houses are assets not goods: Taking the theory to the UK data. Retrieved 24 July 2021, from https://bankunderground.co.uk/2019/09/06/housesare-assets-not-goods-taking-the-theory-to-the-uk-data/

Lodge, S. (2010, March 12). Privatisation shares up 419\% since 1980s. Retrieved 12 September 2021, from https://www.ft.com/content/f35867fa-2e06-11df-b85c-00144feabdc0

Lucas, S. R. (2001). Effectively Maintained Inequality: Education Transitions, Track Mobility, and Social Background Effects. American Journal of Sociology, 106(6), 1642-1690.

Macfarlane, L. (2017, November 13). It's time to call the housing crisis what it really is: The largest transfer of wealth in living memory. Retrieved 17 November 2021, from https://neweconomics.opendemocracy.net/time-call-housing-crisis-really-largest-transferwealth-living-memory/

Macunovich, D. J. (1998). Fertility and the Easterlin hypothesis: An assessment of the literature. Journal of Population Economics, 11(1), 53-111.

Manning, A., \& Mazeine, G. (2020). Subjective Job Insecurity and the Rise of the Precariat: Evidence from the UK, Germany and the United States (CEP Discussion Paper No. 1712). Centre for Economic Performance, London School of Economics and Political Science.

Markovits, D. (2019). The Meritocracy Trap. London: Allen Lane.

McIntosh, S. (2013). Hollowing out and the future of the labour market (BIS Research Paper No. 134). Department for Business, Innovation \& Skills.

MHCLG. (2020). English Housing Survey: Headline Report, 2019-20. Ministry of Housing, Communities \& Local Government.

Michaels, G., Natraj, A., \& Van Reenen, J. (2014). HAS ICT POLARIZED SKILL DEMAND? EVIDENCE FROM ELEVEN COUNTRIES OVER TWENTY-FIVE YEARS. The Review of Economics and Statistics, 96(1), 60-77.

Mijs, J. J. B. (2016). The Unfulfillable Promise of Meritocracy: Three Lessons and Their Implications for Justice in Education. Social Justice Research, 29(1), 14-34.

Miles, D., \& Monro, V. (2019). UK house prices and three decades of decline in the risk-free real interest rate (Staff Working Paper No. 837). Bank of England.

Monbiot, G. (2011, August 29). Academic publishers make Murdoch look like a socialist. The Guardian. Retrieved from https://www.theguardian.com/commentisfree/2011/aug/29/academic-publishers-murdochsocialist 
Mostafa, T., \& Schwabe, M. (2019). Results from PISA 2018: Country Note: United Kingdom. OECD Publishing. Retrieved from https://www.oecd.org/pisa/publications/PISA2018_CN_GBR.pdf

Muellbauer, J. (2018). Housing, Debt and the Economy: A Tale of Two Countries. National Institute Economic Review, 245(1), R20-R33.

Muellbauer, J. (2021). Housing Policy and Fiscal Tools. In 17th Annual Meeting of the OECD Network on Fiscal Relations Across Levels of Government. Retrieved from https://www.slideshare.net/OECDtax/housing-policy-and-fiscal-tools

Mulheirn, I. (2017a, January 16). Part 1: Is there *really* a housing shortage? Retrieved 27 July 2021, from https://medium.com/@ian.mulheirn/part-1-is-there-really-a-housing-shortage$89 \mathrm{fdc} 6 \mathrm{bac} 4 \mathrm{~d} 2$

Mulheirn, I. (2017b, December 19). Is owning a house cheaper than renting it? Retrieved 1 August 2021, from https://medium.com/@ian.mulheirn/is-owning-a-house-cheaper-than-renting-itff5754c4f7f5

Mulheirn, I. (2018a, March 28). Two housing crises. Retrieved 27 July 2021, from https://medium.com/@ian.mulheirn/two-housing-crisis-87a843a9d09b

Mulheirn, I. (2018b, April 20). What would 300,000 houses per year do to prices? Retrieved 24 July 2021, from https://medium.com/@ian.mulheirn/what-would-300-000-houses-per-year-do-toprices-f506e $82 \mathrm{bbe} 8 \mathrm{~d}$

New Scientist. (2018, November 21). Time to break academic publishing's stranglehold on research [Leader]. Retrieved from https://www.newscientist.com/article/mg24032052-900-time-tobreak-academic-publishings-stranglehold-on-research/

Norris, E., \& Adam, R. (2017). All Change: Why Britain is so prone to policy reinvention, and what can be done about it. London: Institute for Government.

Norton, A. (2020). After demand driven funding in Australia: Competing models for distributing student places to universities, courses and students (HEPI Report No. 128). Oxford: Higher Education Policy Institute.

OECD. (2016). Skills Matter: Further Results from the Survey of Adult Skills (OECD Skills Studies). Paris: OECD Publishing.

OECD. (2019). Skills Matter: Additional Results from the Survey of Adult Skills (OECD Skills Studies). Paris: OECD Publishing.

OECD. (2020). United Kingdom. In Education at a Glance 2020: OECD Indicators. Paris: OECD Publishing. Retrieved from https://doi.org/10.1787/ee13f230-en

OECD. (2021a). Brick by Brick: Building Better Housing Policies. Paris: OECD Publishing. Retrieved from https://doi.org/10.1787/b453b043-en

OECD. (2021b). Education spending (indicator). Retrieved 25 November 2021, from https://doi.org/10.1787/ca274bac-en

Oesch, D., \& Piccitto, G. (2019). The Polarization Myth: Occupational Upgrading in Germany, Spain, Sweden, and the UK, 1992-2015. Work and Occupations, 46(4), 441-469.

Oesch, D., \& Piccitto, G. (2020, January 4). The polarisation myth: Europe's job structure is upgrading. Retrieved 14 October 2021, from https://voxeu.org/article/polarisation-mytheurope-s-job-structure-upgrading

ONS. (2020, November 3). Low and high pay in the UK: 2020. Retrieved 27 June 2021, from https://www.ons.gov.uk/employmentandlabourmarket/peopleinwork/earningsandworkinghour s/bulletins/lowandhighpayuk/2020

ONS. (2021a, March 2). Families and households [Dataset]. Retrieved 4 February 2022, from https://www.ons.gov.uk/peoplepopulationandcommunity/birthsdeathsandmarriages/families/d atasets/familiesandhouseholdsfamiliesandhouseholds

ONS. (2021b, May 10). Employee workplace pensions in the UK: 2020 provisional and 2019 final results. Retrieved 3 November 2021, from

https://www.ons.gov.uk/employmentandlabourmarket/peopleinwork/workplacepensions/bulle tins/annualsurveyofhoursandearningspensiontables/latest

ONS. (2021c, November 16). EMP17: People in employment on zero hours contracts [Dataset]. Retrieved 7 February 2022, from https://www.ons.gov.uk/employmentandlabourmarket/peopleinwork/employmentandemploye etypes/datasets/emp17peopleinemploymentonzerohourscontracts/current 
Panigrahi, L., \& Walker, D. (2020, June 3). There's more to house prices than interest rates. Retrieved 24 July 2021, from https://bankunderground.co.uk/2020/06/03/theres-more-to-house-pricesthan-interest-rates/

Präg, P., \& Richards, L. (2019). Intergenerational social mobility and allostatic load in Great Britain. Journal of Epidemiology and Community Health, 73(2), 100-105.

Puehringer, S., Rath, J., \& Griesebner, T. (2021). The political economy of academic publishing: On the commodification of a public good. PLOS ONE, 16(6), e0253226.

Raftery, A. E., \& Hout, M. (1993). Maximally Maintained Inequality: Expansion, Reform, and Opportunity in Irish Education, 1921-75. Sociology of Education, 66(1), 41-62.

Rashid, S., \& Brooks, G. (2010). The levels of attainment in literacy and numeracy of 13- to 19-yearolds in England, 1948-2009. National Research and Development Centre for adult literacy and numeracy. Retrieved from https://dera.ioe.ac.uk/21953/1/doc_4690.pdf

Rea, D., \& Burton, T. (2020). New Evidence on the Heckman Curve. Journal of Economic Surveys, $34(2), 241-262$.

Resolution Foundation Intergenerational Commission. (2018). A New Generational Contract: The final report of the Intergenerational Commission. Resolution Foundation.

Richard, D. (2012). The Richard Review of Apprenticeships. Retrieved from https://assets.publishing.service.gov.uk/government/uploads/system/uploads/attachment_data/ file/34708/richard-review-full.pdf

Rodrik, D., \& Stantcheva, S. (2021). Fixing capitalism's good jobs problem. Oxford Review of Economic Policy, 37(4), 824-837.

Rose, D., Pevalin, D. J., \& O'Reilly, K. (2005). The National Statistics Socio-Economic Classification: Origins, Development and Use. Basingstoke: Palgrave Macmillan.

Royal Statistical Society. (2019, December 23). RSS announces Statistics of the Decade. Retrieved from https://rss.org.uk/news-publication/news-publications/2019/general-news-(1)/rssannounces-statistics-of-the-decade/

Salvatori, A. (2018). The anatomy of job polarisation in the UK. Journal for Labour Market Research, 52, 8 .

Sandel, M. J. (2020). The Tyranny of Merit: What's Become of the Common Good? London: Allen Lane.

Scanlon, K. (2014, June 17). How to bring down house prices in London. Retrieved 21 September 2021, from https://blogs.lse.ac.uk/politicsandpolicy/how-to-bring-down-house-prices-inlondon/

Schmitt, J. (2015, December 22). Can't Disrupt This: Elsevier and the 25.2 Billion Dollar A Year Academic Publishing Business. Retrieved 20 January 2022, from https://medium.com/@jasonschmitt/can-t-disrupt-this-elsevier-and-the-25-2-billion-dollar-ayear-academic-publishing-business-aa3b9618d40a

Select Committee on Social Mobility. (2016). Overlooked and left behind: Improving the transition from school to work for the majority of young people (HL Paper No. 120). London: House of Lords.

Shalchi, A., \& Mor, F. (2021). Registers of beneficial ownership (Briefing Paper No. 8259). House of Commons Library. Retrieved from https://researchbriefings.files.parliament.uk/documents/CBP-8259/CBP-8259.pdf

Sibieta, L. (2021). School spending in England: Trends over time and future outlook (IFS Briefing Note No. BN334). London: Institute for Fiscal Studies.

Strandh, M., Winefield, A., Nilsson, K., \& Hammarström, A. (2014). Unemployment and mental health scarring during the life course. European Journal of Public Health, 24(3), 440-445.

Sutton Trust. (2019). Private Tuition Polling 2019. Retrieved from https://www.suttontrust.com/wpcontent/uploads/2019/12/PrivateTuition2019-PollingTables.pdf

Tenreyro, S. (2018). The fall in productivity growth: Causes and implications (Speech). London: Bank of England. Retrieved from www.bankofengland.co.uk/speeches

Valentine, D. R. (2015). Solving the UK Housing Crisis: An analysis of the investment demand behind the UK's housing affordability crisis. London: The Bow Group.

Wakeling, P., \& Laurison, D. (2017). Are postgraduate qualifications the 'new frontier of social mobility'? The British Journal of Sociology, 68(3), 533-555. 
Washbrook, E. (2013). Do high prices deter fertility? Evidence from England and Wales. Centre for Multilevel Modelling, University of Bristol. Retrieved from http://www.bris.ac.uk/cmm/research/housing/publications/do-high-prices-deter-fertility.html

Willetts, D. (2019). The Pinch: How the Baby Boomers Took Their Children's Future - And Why They Should Give It Back (Revised and updated edition). Atlantic Books.

Williams, B. A. O., \& Nagel, T. (1976). Moral Luck. Aristotelian Society Supplementary Volume, $50(1), 115-152$.

Wilson, W., \& Barton, C. (2017). Foreign Investment in UK Residential Property (Briefing Paper No. 07723). London: House of Commons Library.

Wolf, A. (2002). Does Education Matter? Myths About Education and Economic Growth. London: Penguin.

Wolf, A. (2011). Review of Vocational Education - The Wolf Report. London: The Stationery Office. Retrieved from https://www.gov.uk/government/publications/review-of-vocational-educationthe-wolf-report

Wood, J., \& Clarke, S. (2018). House of the rising son (or daughter): The impact of parental wealth on their children's homeownership (Briefing). Resolution Foundation.

Woodward, P. (2019). Higher Education and Social Inclusion: Continuing Inequalities in Access to Higher Education in England. In R. Papa (Ed.), Handbook on Promoting Social Justice in Education (pp. 1-23). Cham: Springer International Publishing.

Worth, J., \& Van den Brande, J. (2019). Teacher Labour Market in England: Annual Report 2019. Slough: National Foundation for Educational Research. Retrieved from https://www.nfer.ac.uk/media/3344/teacher_labour_market_in_england_2019.pdf

Wren-Lewis, S. (2020, January 21). Evidence and the persistence of mistaken ideas: The case of house prices. Retrieved 24 July 2021, from https://mainlymacro.blogspot.com/2020/01/evidence-and-persistence-of-mistaken.html

Zymek, R., \& Jones, B. (2020). UK Regional Productivity Differences: An Evidence Review (Research Paper). Industrial Strategy Council. 